THE SERVANT-ETHIC IN THE NEW TESTAMENT 


\title{
THE SERVANT-ETHIC IN THE NEW TESTAMENT
}

\author{
By \\ PHILIPPA ANN CARTER, B.A., M.A.
}

A Thesis

Submitted to the School of Graduate studies in Partial Fulfilment of the Requirements for the Degree Doctor of Philosophy

McMaster University

(c) Copyright by Philippa Ann Carter, April 1992 
DOCTOR OF PHILOSOPHY (1992)

MCMASTER UNIVERSITY

(Religious studies)

Hamilton, Ontario

TITLE: The Servant-Ethic in the New Testament

AUTHOR: Philippa Ann Carter, B.A. (University of Toronto)

M.A. (McMaster University)

SUPERVISOR: Doctor Stephen Westerholm

NUMBER OF PAGES: ix, 291 


\section{ABSTRACT}

Biblical scholars have long recognized the diversity in early Christian writing concerning theology and ethics. This dissertation seeks to show that in the New Testament there is a characteristic ethic that is affirmed throughout. This ethic is one of servanthood before others. Each chapter of the thesis focusses on a particular group of New Testament writings and delineates the content of, motives for and limitations upon, the servant-ethic in each group. The content of the servant-ethic is characterized by service to others and the surrender of personal rights and selfish ambition. The ethic is motivated primarily by the desire to fulfill the will of God. The ethic's principal limitation is that God's will must not be violated when seeking to fulfill the servant-ethic. The dissertation concludes that the early Christian self-understanding is one of "other-directedness" and "self-forgetfulness," and that such self-understanding is emblematic of primitive Christian ethical thought as represented in the New Testament. The scope of the thesis is limited to the New Testament primarily for pragmatic reasons. Nevertheless, the conclusion that the servant-ethic pervades this collection of early Christian writing, has implications for scholarship since it maps out some of the ethical territory common to diverse Christian communities in the first century or so of the common era. 


\section{ACKNOWLEDGEMENTS}

The work undertaken in the following pages would have been impossible without the support and guidance of many people.

Sincere and profound gratitude is due my supervisor Dr.

Stephen Westerholm for $h$ is direction and encouragement. His example of academic exactitude and $r$ igour is one that will take me a lifetime to emulate. Shortcomings in these pages are due to my own inadequacy and are no reflection upon him.

Dr. Travis Kroeker made a large contribution to the study by pointing in new directions that 1 would not have explored without his sympathetic guidance. I am thankful for his insight and encouragement.

Dr. Ben Meyer provided much to ponder during my time as a graduate student. He also offered many illuminating suggestions concerning this dissertation. I will always be grateful that he agreed to be part of the advisory process.

My fellow graduate students in the Department of Religious studies at McMaster University provided intellectual stimulation in an atmosphere of camaraderie. Cooperation and support prevailed in the basement of University Hall during my tenure there. I am fortunate to have found such good friends in all my peers. I am especially grateful for the friendship of Alison Miculan, Mavis Fenn and Brad Eastman.

Kristina Bedford provided steadfast encouragement. Her loyal, albeit long-distance, friendship has been particularly heartening.

My parents, Ann and Eric Carter, and my parents-in-law, Damiano and Chiara Padovani, deserve mention for the ir incredible patience, especially during those times they were called upon to care for my children. They always took on this task willingly and $I$ am indebted to them.

My children, Daniel, Chiara and Benjamin Padovani served to keep dissertation-writing in perspective, especially during those onerous weeks of revising. They were unusually cooperative throughout the process. I have been blessed indeed!

Joseph Padovani accepted with unfailing good humour the role of spouse to a graduate student. He provided much-needed support and love during those inevitable times when my task seemed impossible. It is to him that 1 owe the greatest debt of thanks.

The following pages are dedicated with love to the memory of Elsie Carter. 
ABBREVIATIONS

BAGD W. Bauer, W.F. Arndt, F.W. Gingrich and F.W. Danker, Greek-Engl ish Lexicon of the New Testament

BDF F. Blass, A. Debrunner, and R.W. Funk, A Greek Grammar of the New Testament

CBQ Catholic Biblical Quarterly

HTR The Harvard Theological Review

Int Interpretation

LCL Loeb Classical Library

LXX The septuagint

SM The Sermon on the Mount

NTS New Testament studies

NovT Novum Testamentum

JAAR Journal of the American Academy of Religion

JBL Journal of Biblical Literature

JFSR Journal of Feminist studies in Religion

JSNT Journal for the study of the New Testament

JTS The Journal of Theological studies

RAC Reallexikon für Antike und Christentum

RB Revue Biblique

RSV Revised standard Version (All translations are taken from the RSV, except where noted.)

SE Studia Evangelica

SEA Svensk exegetisk årsbok

SJT Scottish Journal of Theologx

SR Studies in Religion

IDNT G. Kittel and G. Friedrich (ed.), The Theological Dictionary of the New Testament 
TynBul Iyndale Bullet in

ZNW Zeitschrift für die neutestamentliche Wissenschaft

(Biblical books are abbreviated according to the JBL) 


\section{INTRODUCTION}

\section{TABLE OF CONTENTS}

The character of the Servant-Ethic 1

The Extreme Nature of the Servant-Ethic 7

The Social Context of the Servant-Ethic 15

The Parameters of the Servant-Ethic 27

Disposition of the study 28

1. THE SERVANT-ETHIC IN THE SYNOPTIC GOSPELS

The Content of the synoptic Servant-Ethic 32

Love of Neighbour

Love of Enemies

Service to the Poor

Rejection of Social Hierarchies

The synoptic Motives for Serving others 53

Mark

Matthew

Luke

Summary of Motives

Limitations upon the synoptic Call to Serve 86

Conclusions Concerning the Ethic in the synoptics 96

11. THE SERVANT-ETHIC IN THE JOHANNINE WRITINGS 99

The Motives for the Footwashing and Service 102

The Requirements of Serving as Jesus Served 108

$\begin{array}{ll}\text { The Benefits of Mutual Service } & 118\end{array}$

Relationship of the Footwashing to the
Johannine Ethic

Limitations upon Service in the Johannine
Literature

Relationship to the Synoptic Gospels 131

Conclusions Concerning the Ethic in John 134 
The content of the Servant-Ethic in Paul

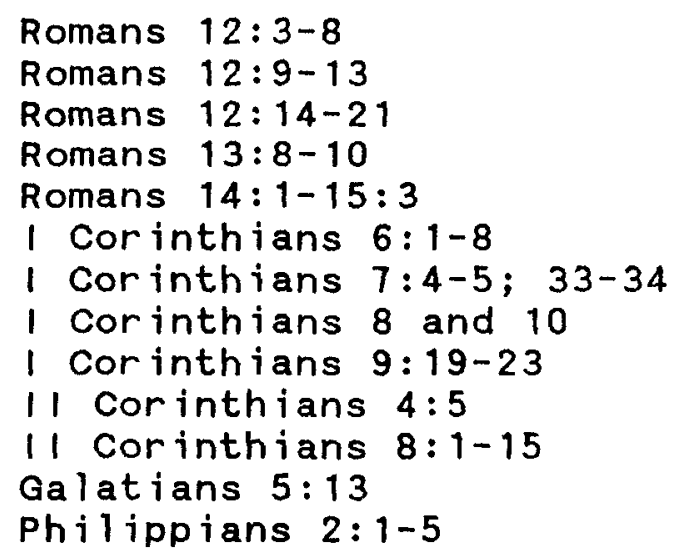

The Motives for the Pauline Servant-Ethic

Service to others for Christian Unity The Promise of Reward

Serving Others as Imitation of christ Serving Others for the Sake of the Gospel

Conclusions: Freedom in Christ and Serving Others 202

IV.THE SERVANT-ETHIC IN OTHER NEW TESTAMENT WRITINGS 208

The Servant-Ethic in Acts 208

The Servant-Ethic in Colossians $\quad 212$

The Servant-Ethic in Ephesians 217

The Servant-Ethic in the Pastoral Epistles 220

The Servant-Ethic in Hebrews 223

The Servant-Ethic in James 229

The Servant-Ethic in 1 Peter 237

$\begin{array}{lr}\text { Conclusions } & 246\end{array}$

A Note on II Peter and Jude 248 
V. THE NEW TESTAMENT SERVANT-ETHIC--CONCLUSIONS AND

The content of the Servant-Ethic

The Call to Love Others

The Call to Serve the Poor

The Call to surrender One's Rights

Rejection of Social Rank and Selfish Ambition

Unifying Motif--Placing One's Interests Last

The Motive to Place One's Interests Last

Jesus Christ as Paradigm

The Preservation of Unity

To Ensure the Spread of the Gospel

Reward

Unifying Motif--Responding to God's Grace

Limitations Upon the Servant-Ethic

Questions of Prudence and Common Sense

The Primary Limitation--Violating God's Will

The Freedom to Serve

The Self and the other and the New Testament Servant-Ethic 


\section{INTRODUCTION}

The Character of the Servant-Ethic

Many scholars have noted that the ethics of the New Testament are not systematic and that it is impossible to derive a coherent moral system from these early christian writings. We are assured that the early Christian communities were diverse in matters of ethics and kerygma. 1

1 Jack sanders, in arguing that the New Testament provides no material for a valid ethics for today, emphasizes throughout $h$ is study the variations in the moral postures of the writers; for example Paul and James (Ethics in the New Testament [Philadelphia: Fortress, 1975] 129). While we are not concerned primarily with the viability of New Testament ethics for today, Sanders has neglected the impact of the New Testament for the very issue we undertake to examine here: the consistent emphasis in the New Testament upon the surrender of self-interest in human relations.

With regards to kerygma, James Dunn cautions his readers against seeking any central unifying element in the New Testament beyond the "continuity of the historical Jesus with the exalted Christ" (Unity and Diversity in the New Testament [Philadelphia: Trinity, 1990] 369-70). In their response to the proclamation of or about Jesus, however, the New Testament records that early Christians understood their posture towards others to be one of self-sacrifice after the manner of Jesus; the theme appears to be consistently reflected in the New Testament writings.

In a recent article Eugene $E$. Lemcio disputes Dunn's conclusions by claiming that, "contrary to the prevailing view, there is a central, discrete kerygmatic core that integrates the manifold plurality of the New Testament" ("The Unifying Kerygma of the New Testament" in JSNT 33 [1988] 3). While our investigation is not primarily concerned with kerygma, Lemcio's article is important because his procedure involves "a study of the New Testament per se, which is first and foremost a body of 
This is especially the case if we look to ethics for ways of characterizing early Christianity as a whole. That no systematic ethic can be found or extracted from the New Testament is hardly surprising, we are further informed, considering the number of authors and genres found there.

The writings of the New Testament spoke to the early Christians in ways that illuminated their selfunderstanding as part of the people of God. For all these Christians the person of Jesus, crucified and resurrected, represented a momentous work of God in history. Their response to this act, to the extent that it involved human conduct, was ethical in nature. Can it be that there is no ethical principle familiar to each of these communities that permeated their self-awareness as Christians? Is it possible that diverse groups of people, each of which was moved to believe that in Christ God had performed a unique and decisive act in human history, did not reveal this common conviction in comparable ways in their reflections on human conduct? Is it not to be expected, that despite the variety and diversity found within the New Testament canon in matters theological, there should be some fundamental

literature. Such textual examination has an integrity in its own right, so that it may be conducted separately from and indeed prior to the historical" (Ibid., 5). The state of the quest for thematic unity in the New Testament documents has recently been summarized and the quest itself pursued by John Reumann (Variety and Unity in New Testament Thought [Oxford: Oxford University Press, 1991]). 
agreement in how the human response to this divine act

should be characterized in concrete action? We seek, therefore, a recurrent note throughout the New Testament canon, which identifies, in terms of ethics, the selfunderstanding of the early Christians. 2

Love is often mentioned as the Christian virtue par excellence. To be sure love is a prominent motif in many of the early Christian writings and believers are exhorted over and over again to love their fellow Christians, their neighbours and even their enemies. But love of neighbour is

2 of late, greater sensitivity to historical accuracy and objectivity has led to the call to discard the notion of "New Testament" when engaging in the study of the early Christian communities since these writings were not incorporated into the canon until much later. Since the earliest believers did not have a New Testament, the argument goes, it is anachronistic to limit our study of them by focussing simply upon those documents later considered canonical. Although 1 am sympathetic to this viewpoint and am suspicious of most arguments that understand convention or custom to be somehow sacrosanct, 1 find myself soliciting the reader's indulgence since this study is limited to the documents found within the New Testament. I am aware that there are other writings contemporaneous with, or even earlier than, some of the New Testament documents, and which are also representative of early Christian self-understanding. The New Testament remains, however, the principal collection of earliest Christian writings in terms of the sum of its audience and the focus of scholarship. Thanks to the last one hundred years or so of New Testament criticism the following pages endeavour to seek a characteristic ethical selfunderstanding in the writings of the earliest believers that scholars affirm come from the first century following the death of Jesus. Therefore, out of convenience, and out of the conviction that these writings are in themselves suggestive of a great variety in primitive Christian selfunderstanding, the focus of the following pages is limited to those documents found in the New Testament. 
essentially an abstract principle in the sense that it needs to be defined in terms of the actions it gives $r$ ise to. ${ }^{3}$ Nevertheless, one suspects that related to love, indeed having their source in love, other ethical themes or principles can be found which point to a degree of moral coherence throughout the New Testament. One of these themes is what 1 would term the "servant-ethic." By this phrase 1 mean the consistent who says:

${ }^{3}$ This does not necessarily contradict Wolfgang schrage

If there is common agreement that love is the general tenor of New Testament ethics as well as the center and quintessence of all the individual admonitions, it must remain clear that this love implies quite specific content and criteria; it is not an abstract formal principle (The Ethics of the New Testament [Philadelphia: Fortress, 1988] 11).

Gene Outka, in his attempt to clarify the role of principles and rules in moral reasoning, turns to the commandment to love one's neighbour. He says:

I shall call this commandment an ungual ifiedly general principle, by which 1 mean that it is (a) applicable to everyone unrestrictedly, (b) and on every occasion so that it is always relevant, (c) and serves as the basis of subsidiary principles and rules, providing the fundamental justifying reason or warrant for their existence or the purpose or intent underlying them ("Character, Conduct and the Love Commandment" in Norm and Context in Christian Ethics, edited by Gene $H$. Outka and Paul Ramsey [New York: Charles Scribner's Sons, 1968] 40, emphas is his).

Schrage's implied "specific content and criteria" perhaps parallel Outka's "subsidiary principles and rules" and it is one dimension of these that the following pages deal with. 
denial of one's own interests in favour of those of others, and the willingness to stand unfailingly ready to serve others. The "servant-ethic" represents the "otherdirectedness" and self-sacrifice that is a recurring note throughout the New Testament and characterizes the selfunderstanding of the early Christians. It is informed by love and embraces such qualities as humility, forgiveness, respect, consideration and empathy. It is advocated for many reasons and is carried out in many different ways, but its paradigm is the one who came to serve and to give $h$ is life as a ransom for many (Mk 10:45).

It should be noted at this point that $I$ do not mean to suggest that only the early Christians sought to practice such an ethic. Respect for the interests of others and self-denial can be found in all religions, and 1 am not suggesting that the earliest christian believers have a monopoly on self-sacrifice and empathy. What 1 do want to show is how fundamental the "servant-ethic" is in the New Testament, how extreme the requirements of this ethic are for the early christians, and how this principle is affirmed again and again throughout the earliest Christian documents.

The "servant-ethic" is a connecting link which, although not kerygmatic in nature, points to a degree of coherence in New Testament ethics. By this 1 mean that it offers a normative standard for Christian behaviour involving relations with others. While the writings of many 
traditions encourage their adherents to consider the wishes and needs of others, few, including much of modern Christian thought, consistently couch this requirement in such extreme terms of self-denial and servanthood as do the early Christian documents.

It will prove fruitful to examine the servant-ethic as it arises in each genre and section of the New Testament in terms of its content and limitations, and the motives for its implementation. In the process we will discover that the earliest Christians did in fact have a view of ethics that was fundamentally coherent and consistent and was described in similar terms by disparate groups.

The New Testament summons the people of God to relinquish their own interests in order to serve others. The true disciple, the authentic christian, is one who renounces the self and becomes "other-directed." such "other-directedness" is not, however, "self-forgetfulness" in the sense of attaining an altered consciousness ak in to that advocated in esoteric Hindu and Buddhist schools. It also is not the kind of self-denial that involves deliberate "mortification of the flesh" and the pursuit of bodily affliction for its own sake. The servant-ethic, in its New Testament form, does not recommend that one endeavour to overcome the limits of human consciousness or deliberately seek after suffering. Rather it promotes humility and the acceptance of one's weakness before God, 
and empathy in the face of another's suffering. The servant-ethic flouts convention by inhibiting and rejecting ambition and social prestige, while accepting the lesser position and acquiescing in the face of conflict. For the New Testament writers it was the mark of those who had become part of the people of God.

\section{The Extreme Nature of the Servant-Ethic}

The biblical tradition is unequivocal in its avowal of the just nature of God. He is portrayed as fair and impartial while at the same time acting as the defender of his people. Stephen Mott points out that in the Bible justice often is found to be closely allied with grace.4 Mott understands God's justice, which his people are to emulate, to entail especially the protection of the poor, the weak and the oppressed. He points out that biblical justice is not simply punitive, but "also vindication, deliverance, and creation of community." 3 God has bestowed grace on his people because of $h$ is love toward them and they, in turn, are to act justly towards others. Citing Deut 10:18-19, Mott asserts that for God's people performance of justice is not based on considerations of

4 Biblical Ethics and Social Change (New York: Oxford University Press, 1982) 59-62.

5 Biblical Ethics, 63. 
personal worth or merit but upon need and the awareness of God's grace:

It is this assumption which allows justice to
be expressed by the principle of
equality.... The presence of grace and love in
justice universalizes the formal principle of
equal treatment of equals, shows a regard for
the needs of each person, and creates the
obligation to seek the good of each. The
well-being and freedom of each other person
becomes as valuable to me as my own.6

We need to ask, however, if and when the well-being and freedom of the other become more valuable than those of the self. The New Testament seems consistently to invoke the principle that one's own interests should be subordinated to those of others even when one's own may be asserted justifiably. In other words, God now calls his people to become the weak and oppressed in the sense that rights and privileges that may be claimed often are to be surrendered.

The call to love one's neighbour as oneself is a good starting point to determine the limitations, if any, of the servant-ethic. We need to discover whether the New Testament ever suggests, or even hints, that in certain circumstances the love of oneself supersedes the love of one's neighbour. The short answer to such an inquiry is no and we shall pursue this more thoroughly in the chapters below. The situation in which the interests of self take precedence is the situation in which the neighbour is loved

6 Biblical Ethics, 64 . 
less than oneself. Nevertheless, as modern theologians and ethicists are often wont to point out, the love of self sometimes comes into a real and painful conflict with the love of neighbour. Writing as a contemporary christian ethicist, Joseph L. Allen attempts to resolve this dilemma by arguing that love of self can be distinguished from "serving the interests of the self." His argument illustrates how extreme the New Testament requirement to serve actually is.

For Allen it is possible for the inner disposition of the self in relation to itself to be one of love even when external actions lead to self-sacrifice on behalf of others.? He also distinguishes between selfishness and self-love by defining self-love as self-acceptance and self-affirmation. This acceptance and affirmation is derived from God's act of accepting and affirming the self independent of any merit. ${ }^{8}$

In Allen's view, the solution of impartiality in which the self attempts to treat others and itself in exactly the same way is more often than not impossible. Indeed, for christian thinkers this is usually held to be non-Christian. The interest of the other outweighs the interest of the self, according to Allen, for two reasons

7 Love and Conflict: A Covenantal Mode of Christian Ethics (Nashville: Abingdon, 1984) 105.

Love and Conflict, 107 . 
based on the Christian's faith in God. First, this faith leads to reliance upon God to provide for one's needs. Pointing to Matt $6: 25$ Allen says that "Faith...frees a person from the kind of self-concern that would lead to defensiveness...about getting an equal share, at least where justice to others does not depend upon justice for the self."9 Allen then notes the positive side to this negative elimination of self-concern. This is the liberating aspect of faith, "freeing one for concern for the other":

Faith is that by which the self not only has a right to sacrifice its own interests for those of others, but also is inclined not to be anxious for the self but to give of its resources to serve others.10

\section{${ }^{9}$ Love and Conflict, 114 .}

10 Love and Conflict, 114 , emphasis his. I find Allen's discussion compelling here in that the right to sacrifice somehow is subordinated to the inclination to sacrifice. Allen quotes Luther to support his view that Christian faith liberates and thereby inclines one to sacrifice on behalf of others. Lambert's translation reads:

Although $\mathrm{I}$ am an unworthy and condemned man, my God has given me in Christ all the riches of righteousness and salvation without merit on my part...so that from now on I need nothing except faith which believes that this is true.... will therefore give myself as a Christ to my neighbour, just as christ offered himself to me; 1 will do nothing in this life except what 1 see is necessary, profitable and salutary to my neighbour, since through faith I have an abundance of all good things in christ ("The Freedom of a Christian" in Luther's Works 31 [Philadelphia: Muhlenberg 1957] 367). 
Allen, however, wishes to pursue his course still further to discover whether such self-sacrifice on the part of christians is, in fact, a duty or obligation. He suggests that one "has a strong but not an absolute duty to give priority to the interests of others." 1 While acknowledging that in the New Testament "concern for the interest of others clearly takes priority over concern for the interests of self,"12 he also insists that the self also remains obligated to itself. His reservations are based on the observation that self-sacrifice for its own sake can lead to self-destruction which benefits no one. "The point is that self-sacrifice is not an end in itself, but a means to the service of others."13 Using such arguments Allen defends the position that on many occasions one should advance one's own interests in order to advance the interests of others or to illuminate the injustice of others' acts. Finally, Allen argues, the occasion often arises where the interest of the self should be protected so that it may serve others at a future time.14

'Love and Conflict, $1 i 6$, emphas is his.

12 Love and Conflict, 117. Allen points to Matt $10: 38$ 39 ; 16:24-26; 25:31-46; Mark 8:34-36; Luke 9:23-24; $10: 29-$ $37 ; 14: 27 ; 17: 33$; John $12: 25$; and I Cor 10:24.

13 Love and Conflict, $118-119$.

14 Love and Conflict, 122-125. In his book Jesus on Social Institutions (Philadelphia: Fortress, 1971), Shailer Mathews suggests that the sacrificial love to which Jesus calls his disciples is in a sense strategic because it 
The problem with Allen's argument in the context of our study, a problem that he himself acknowledges, is that it would seem alien to the earliest christians. In the New Testament, the consistent call to serve the interests of others first leaves little room for considering future benefits for others by asserting one's rights, or assuming that one will make a useful contribution to the well-being of others later on. Each instance of encountering another person--that is, the neighbour--becomes the point at which a believer must decide whom to serve. The future is in God's hands: the future of the self and the future of the other. At such critical moments there is no time for ethical debate. The decision is to be made, according to the New Testament, based on faith and the understanding of God's

ensures the welfare of the individual by promoting the welfare of the group. He describes Jesus' call for love as a call for social cooperation. "The welfare of the individual is furthered by the cooperation of all those who are members of the group. They can act egotistically only at the cost of suffering in the group" (55). There is, however, no evidence in the texts to support such an evaluation of Jesus' teaching. The calls to the servantethic and love for the other do not function as insurance of one's own well-being, although they may have that effect, but rather as the natural manifestation of the disciple's faith in God.

It is perhaps important to note that while the New Testament text may advocate a position that is different from that held by modern scholars, most notably Christian theologians and ethicists, we are not suggesting that their arguments are thereby necessarily invalid. The role of scripture in modern theology and ethics is part of an ongoing debate and modern ethical discussions take place in a social context that is far different from that of the early christians. 
will for that moment. In the New Testament it seems clear

that such occasions demand the denial of self as the

Christian responds by faith in freedom and love to the call

of God's grace.15 The New Testament then seems to take a

more rigid stance than Allen on the question of serving the

interests of others. Questions of justice, of rational

self-interest, become subordinated to the insistence of

15 Some scholars suggest that such ethical urgency is the product of the eschatological outlook of the early church. They suggest that the need for prudence is diminished if one believes the eschaton is at hand. An example of such an evaluation is found in Jack T. Sanders' consideration of the ethics of Jesus. He says:
If we are correct in attributing the freedom involved in the ethical demand [i.e. to love one's neighbour] stemming from jesus to his awareness of the imminence of the righteous God, then we shall have to say that the removal of the eschatological orientation from Jesus' ethical teaching would leave a truncated obligation.... For Jesus eschatology is constitutive for ethics.... To put the matter now most sharply, Jesus does not provide a valid ethics for today. His ethical teaching is interwoven with his imminent eschatology to such a degree that every attempt to separate the two and draw out only the ethical thread invariably and inevitably draws out also strands of the eschatology, so that both yarns only 1 ie in a heap (Ethics, 28-29).

As we shall see, however, the servant-ethic does not in fact seem to be closely tied to eschatological expectations. Indeed, for Paul the effect upon the community's future cohesiveness on earth is often a strong motive for calling his readers to fulfill the servant-ethic even to the point of suffering injustice (e.g I Cor 6:1-11). For a more sober analysis of the impact of eschatology upon Christian ethics, see C.H. Dodd, Gospel and Law (New York: Columbia University Press, 1951) 25-32. 
putting others first in the immediacy of the moment.16 in

16 In his discussion of how Christians discern the way in which they ought to conduct themselves James Gustafson tries to identify what $k$ inds of considerations are brought to bear. The correct application of the love-command in some situations is self-evident. In other circumstances he notes that moral reflection requires a greater degree of sophistication.

When sophistication is required, the christian is involved in the process in which the situation must be defined (its proper time and space limits determined, its complex of relationships delineated, its data formulated and organized); in which other principles bearing on the case that might not be easily harmonized with the love commandment have to be stipulated and recalled, other theological reference-points than love remembered, other values than love designated, and the use of "love" itself carefully delineated so that it has some particularity and does not cover anything. He is involved in a process in which analogies from scripture or from the moral experience of the community are rehearsed and brought to bear; in which moral sensibilities are recognized, judged, and affirmed or qualified by reflection; and in which finally a judgment is made about what God is enabling and requiring.... Reflection is necessary because Christians, like others, tend to be conformed to the expectations of their own desires and to the ethos of the time in which they 1 ive, rather than remembering that they are not to be conformed to this world ("Moral Discernment in the Christian Life" in Norm and Context in Christian Ethics [New York: Charles Scribner's Sons, 1968] 33$34)$.

While I do not want to depict the early Christians as unreflective, the New Testament does not seem to encourage the conviction that much consideration is required of the christians to act appropriately. The early Christians undoubtedly faced situations in which it was not clear how one might express love of neighbour. One senses that it was not sophistication that was required so much as ingenuousness: the belief that God's will would prevail in one's own self-forgetfulness and "other-directedness." 
short, prudence, even if defined as practical wisdom, becomes less important.17 While Allen's discussion may be persuasive, it is at odds with the New Testament position. It serves therefore to highlight the strange and radical nature of the language of the New Testament servant-ethic.

The Social context of the Servant-Ethic

Christians understood themselves to be called by God to be servants to others, to thwart egotistical ambition, and to surrender their own rights and privileges. The language used to describe such behaviour is often extreme in its connotations. Words such as doulos and diakonos and their cognates are by no means flattering in their implications. The former especially smacks of debasement and humiliation. We need to consider the ramifications of such language and its possible sources. Doulos and diakonos and their cognates often occur in passages that delineate the ideal moral stance of Christians; in many passages they are called to become slaves or servants of others. What can such language mean in an environment that recognized a slave as the occupant of the lowest level of the social pyramid,

17 Gustafson, however, equates discernment with prudence and disputes Paul's assertion, "Then you will be able to discern the will of God." Gustafson says, "I suspect that more modest claims would be more precise. By offering oneself up to God, and by formation in prudence informed by love and faith and hope, "Then you might discern the will of God" ("Moral Discernment" 36, emphasis his). 
or, metaphorically, as a description of the pious individual before God? 18

Although the doulos was situated at the rock bottom of society some slaves managed to turn the situation to their own advantage. At the turn of the era many slaves managed to wield a certain amount of power and influence by virtue of their role as aides to powerful and influential men. The first part of $s$. Scott Bartchy's study First Century slavery and 1 Corinthians $7: 21$, and the first chapter of Dale B. Martin's slavery and Salvation both emphasize the amazing complexity of institutionalized slavery in the Greco-Roman world. Bartchy notes that legal limitations began to be placed upon the rights of masters under Roman $\mathrm{law}$, and that the status and disposition of the slave-owner markedly influenced the quality of life enjoyed by $h$ is slaves.19 This resulted in the paradox that it was often better to be a rich man's slave than a poor man's employee, for the former was at least guaranteed shelter, food and clothing.

Both Bartchy and Martin note that slaves performed many jobs also undertaken by free and freedmen and that it was not simply the menial or unhygienic tasks that were

18 Many individuals in the Hebrew Bible are designated servants ('ebed) of God (e.g. Moses (Exod 4:10; 14:31), David (I Kgs 11:34) and Elijah ( I Kgs 18:36). 1971) $67-70$.

19 First Century slavery (At lanta: Scholars Press, 
reserved for slaves. Slaves often occupied positions of trust as financial managers, and of influence as educators in the households of more wealthy individuals.20 Nevertheless, under Greek and Roman law the slave had virtually no legal status whatsoever. The idea of voluntarily becoming like a slave to another, even if only in a figurative sense, would have been alien to Jew and Gentile alike. Aristotle likens a slave-mentality not only to the status of those who are slaves but also with those who are bereft of virtue.21

Other Greek thinkers equated slavery with enslavement to passions and taught that even a slave could experience true "inner freedom." The stoics, for example, held that a slave could be virtuous but saw no benefit in free and freed men thinking of themselves as servants of others in any concrete sense. The writings of the stoic Epictetus are important for our purposes because they come from the pen of

20 See Bartchy, 73-78, D. Martin, Slavery as Salvation (New Haven: Yale University Press, 1990) 11-22. Also see Wayne Meeks, The First Urban Christians (New Haven: Yale University Press, 1983) 20-22.

$21 \mathrm{Eg} \mathrm{Nich} \mathrm{Eth.} 111 . i .2-8$, concerning behaviour under compulsion; III.vii.5, concerning the courageous man; and V.ix.1-3,8 on the belief that one should not suffer injustice voluntarily. (George $F$. Thomas offers a decidedly negative summary of Aristotle's ethics in comparison with those of Christianity in "Aristotle's Theory of Moral virtue" in Christian Ethics and Moral Philosophy [New York: Charles Scribner's Sons, 1955].) 
a former slave who experienced first-hand the oppression and harshness of a life deprived of autonomy.

The stoics were primarily concerned with achieving an inner harmony and disposition that bred indifference to external hardship. This harmony extended to an individual's relations with others and was dictated by one's duty and social position. For Epictetus the most dangerous form of bondage was ens lavement to vice which upset the serenity born of reason and seeking the highest good. Thus, even when maltreated, Epictetus seeks to respond with equanimity:

If...We define the good as consisting in a right moral purpose, then the mere preservation of the relationships of life becomes a good; and furthermore, he who gives up some of the externals achieves the good. "My father is taking away my money." But he is doing you no harm. "My brother is going to get the larger part of the farm." Let him have all he wants. That does not help him at all to get a part of your modesty, does it, or of your fidelity, or of your brotherly love? Why, from a possession of this kind who can eject you? Not even Zeus. (Epictetus, Diss., I1 . i i i.4-12).

This principle of striving after the highest moral good and cultivating a tranquil disposition leads for Epictetus to true freedom. Moral rather than social freedom (eleutheria) is most important for Epictetus and his fellow stoics:

No man who is in fear, or sorrow, or turmoil, is free, but whoever is rid of sorrows and fears and turmoils, this man is by the selfsame course rid also of slavery (Epictetus, Diss. $(1, i .24)$. 
The clearest exposition on this question of moral freedom is found in Diss. 1.i. Here Epictetus explains how even free men are enslaved if they do not understand that striving to satisfy a desire is a sinister form of slavery. Freedom is achieved when desire is destroyed (Diss.IV.i. 175). Thus, even a slave who manages to buy his emancipation is not truly autonomous unless he can destroy his desire for money and finery (Diss. IV.i.33-40). Despite this, Epictetus does not use the language of servanthood or slavery to describe one's ideal relations to others.22 such relations are marked by indifference if one is treated unjustly, which may appear similar to the principle of turning the other cheek; but the goal is personal equanimity and moral integrity, not service to others.

Likewise, in Jewish thought, an individual could be a servant of $\operatorname{God}^{2} 3$ but there are clear biblical prohibitions

22 Marcus Aurelius, Epictetus' disciple says, however:

Pass through the remainder of thy days as one that with his whole soul has given all that is in $h$ is trust to the gods, and has made of himself neither a tyrant nor a slave to any man (IV:3, emphasis mine).

23 For example Moses is often considered to be God's greatest servant. In the LXX doulos is used in this context at 111 Esdr 20:30 where it stands for the Hebrew ebed. In other passages, however, pais is used instead ( 1 Chr 6:34, I1 Chr 24:9). In the LXX three words predominate in the translation of 'ebed (doulos, pais and therapōn). The last of these, therapon, is used not only to describe Moses role as God's servant (Num 11:11, 12:7; Deut $3: 24$; Josh $1: 2$, $9: 2)$, but is also used to describe other figures in their roles as servants of God (e.g. Num 32:31; Deut 9:27; Job 
upon Hebrews enslaving other Hebrews, 24 and in general the servant-vocabulary is not characteristic of Jewish writings when one's ethical relationship to others is considered.25 It is also difficult to determine to what extent Rabbinic literature can be used to investigate slavery in the first century C.E. E. E. Urbach is adamant that there are no grounds for assuming that Jews did not practice slavery in the period of the second Temple, and indeed afterwards. He insists that Mishnaic references to slavery

$1: 8,2: 3 ; 42: 7,8)$. The word therapon also refers to the servants of Pharaoh throughout the account of the Hebrews ' departure from Egypt (Exod 4-11; Deut 29:1, 34:11). In the New Testament therapōn is only used once (Heb 3:5) where it again refers to Moses as God's servant over against Jesus' role as God's son (huios, Heb 3:6). Pais is used to translate 'ebed far more frequently. Zimmerli, in his article "pais theou" (TDNT $V, 654-717$ ), notes that pais rather than doulos is the preferred term in the first six books of the LXX, although therapon is predominant numerically in Exodus. He suggests that "this phase of translation was marked by a strong and uninhibited approximation to the Greek sense of the nearness of God and man" (675), presumably because of the ambivalent nature of the word pais in Greek. Doulos, as Zimmerli notes, is rarely used in the Hexateuch to translate lebed: in fact, there are only six instances (Lev 25:44, 26:13: Deut 32:36; Josh $9: 23 ; 14: 7,24: 30$ ). Of these, only Deut $32: 36$; Josh $14: 7$ and $24: 30$ refer to doulos in the religious sense as a slave of God or the Lord. (Rahlf's edition gives two readings of Josh $14: 7$, although ho pais tou theou is preferred to doulos kuriou.) Outside of the Hexateuch, however, the word doulos stands for 'ebed, with a much smaller percentage of exceptions.

24 Lev $25: 35-55$

25 We might note, however, the surrendering of rights that is found in Genesis 13 in which Abram defers to Lot for the sake of peace, and in Gen 26:17-22 in which Isaac follows a similar course to avoid contention. 
are not necessarily hypothetical.26 Paul V. Flescher

demurs, however, and says that "Urbach's attempt to use laws as evidence of actual historical practice is...misguided."27 According to Flescher, Urbach interprets the laws in the Mishnah as descriptive rather than as prescriptive.28

Whatever the relation of the Mishnah to actual historical circumstances it has much to say about slavery. Flescher describes the Mishnaic view of the slave as different from that of Aristotle:

In brief, the Mishnah's framers recognize the bondman as a complete human being, but as one whose status as property prevents him from achieving his full potential. Sages do not portray him as a sub-human "monster," that is, as something lacking the full rudiments of humanity. 29

26 "The Laws Regarding slavery as a Source for Social History of the Period of the Second Temple, the Mishnah and Talmud". Papers of the Institute of Jewish studies, London 1 (Jerusalem: Magnes Press, 1964) 8 .

27 oxen. Women or Citizens? Slaves in the system of the Mishnah (Atlanta: Scholars Press, 1988) xii.

$28 \mathrm{Flescher,} x i-x i i$. The institution of slavery was a political, social, and economic reality in the first century C.E. It was apparently rejected only by the Therapeutae and the Essenes. (See Philo, "The Contemplative Life," 70 and "Every Good Man is Free," 75-78.) Philo, himself, shows no discomfort with the social division of human beings into slave and free. For him and his contemporaries such a division was as natural as that of male and female. As Barclay says: "In the normal run of life, where the timehonoured structures of society seemed unchangeable, it was impossible to imagine a slaveless society, except in a utopian dream-world where food cooked itself and doors opened of their own accord" ("Paul, Philemon and Christian Slave-Ownership," in NTS 37 [1991] 177).

29 oxen, 37 . 
Like the Greek and Roman situation the circumstances of slavery as portrayed in the Mishnah are complicated and ambivalent. According to Urbach, rabbinic Judaism understood slaves to be under the complete control of their masters. Even the former's property and money belonged to their masters so that manumission could only be paid for by a third party. Urbach shows that "the Halakhah sensed an incompatibility between being the beneficiary of an assignment of property and servile status, and pronounced that such a transaction carried as its consequence complete emancipation [Pe'ah 3:8; Tosefta 1:13]."30

Although scholars have shown that many slaves enjoyed a certain degree of power and wielded some influence over their own fate, ${ }^{3} 1$ it is clear that the word "slave" as such denoted a person with no rights, who was indebted to and under the authority of another. When speaking of the use of the doulos word-group in the LXX, Rengstorf notes that "it always stands in opposition to the thought of freedom. It thus expresses with singular force both the extreme of power demanded and exercised on the one side and the extreme of objective subjection and subjective bondage present and experienced on the other." 32

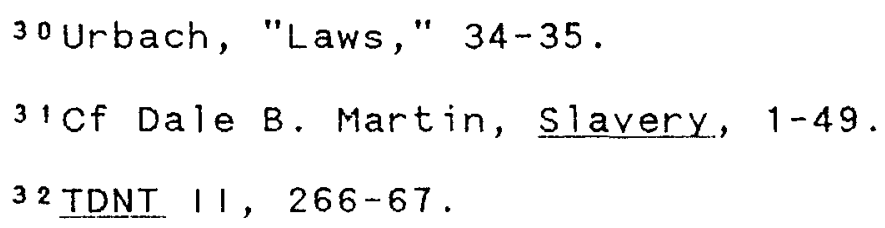


Although the social milieu and the extent of influence of Greek and Jewish literary traditions cannot be surveyed extensively here, scholarship has shown that to become a slave to others in any sense was not high on anyone's list of ethical priorities. Slaves were essentially bereft of rights, although masters were encouraged to treat their slaves humanely and manumission was an option under certain conditions. It is this lack of rights in relation to others that is particularly important for the servant-ethic. In the New Testament the requirement to place the interests of oneself last often is couched in terms of servanthood.

The use of servant vocabulary can also have a sinister aspect which must be faced. It is no secret that some New Testament texts have been used in the past to justify and perpetuate oppression, including institutionalized slavery.33 Many Christians are embarrassed by the lack of an outright condemnation of slavery by any New Testament writer. This aspect of the text has to be faced and accepted. It also has to be placed in its historical perspective. The early Christians lived

${ }^{3}$ Examples and discussions abound but for a brief summary see Clarice J. Martin, "Womanist Interpretations of the New Testament" JFSR 6 (1990) 55-59. See also the first part of Willard $M$. Swartley's book, Slavery. Sabbath, War, and Women (Kitchener, Ontario: Herald Press, 1983) 3153), for a concise summary of 19 th century pro-slavery and abolitionist arguments based on biblical texts. 
in a world of slaves and masters. This dimension of the social structure clearly provided a model for christian ethical behaviour.

The New Testament, in fact, neither condemns nor encourages slavery. Where slavery exists it is accepted but there is no text that encourages individuals to acquire slaves. The emphasis is upon promoting behaviour appropriate to the christian life in the social context within which one finds oneself. The subjugation of an individual by another is prohibited, not only in the sense of perpetuating slavery but in other matters as well. Christians are not actively to seek to dominate others, even in the sense of imposing their own views upon their fellows. In his discussion of eating sacrificial foods paul encourages his readers to halt such practices if they offend others, even though such behaviour may not in itself be idolatrous ( 1 Cor 8-10; Rom 14:13-23). It becomes morally wrong to assert one's own rights and privileges as a Christian at the expense of another's conscience. How can a Christian, who has accepted as truth the paradox of the crucifixion, insist on advancing her or his own rights as a Christian "free in christ"? The servant language imparts to the New Testament writers' ethical discussions a ready model for the Christian's relations to God and to others. The use of such language raises potential moral problems because it can be abused, but it also sharply 
depicts the radical nature of Christian conduct. Claims about God's action in history in the death of Jesus are elucidated by the early Christians' self-understanding regarding their status as slaves to others. Luther's paradox of being lord of all yet slave of all follows as the ethical consequence of early christian beliefs about the moral significance of the paradox of the crucifixion and resurrection. As Paul tells his readers in Gal $5: 13$, freedom in Christ means the freedom to become a slave to others in love. The believer becomes free to serve: in responding to God's grace the christian has chosen to eschew ambition in order to advance the interests of others. This is no longer merely a duty, it is the result of a conscious decision and is the hallmark of a true Christian.34

The New Testament consistently indicates that an individual, upon becoming a Christian, surrenders personal

34 Emil Brunner notes that "duty and genuine goodness are mutually exclusive" (The Divine Imperative [London: Lutterworth, 1937] 74) He continues:

Above all, freedom means being free from the obligation to seek one's own good. Freedom is utter dependence upon God, and this means the absolute renunciation of all claims to independence, of all illusory independence over against God (78).

At the same time, however, the requirement to serve others because an individual is a christian can be described in terms of duty and obligation. Fulfilling the servantethic does not make an individual a Christian, however. It is the result of becoming a Christian not the cause or prerequisite. 
rights before others. While the human inclination is to seek higher status in society, the New Testament seems firm in its insistence that such ambitions are inappropriate (e.g. Mark 10:42-45; I Cor 7:21). All Christians are called to understand that as Christians they become slaves to one another (Gal 5:13), that by seeking to obey God they are required to serve other people. They become servants, not only before God, but before others as well. The example of Jesus as slave or servant (Phil 2:7; Mark 10:45; I Pet 5:5) gives shape to this conviction and reinforces the attitude that leads to submission to others. The New Testament writers do not transform the meaning of doulos or diakonos; rather they embrace it as a way of identifying those who, by following Christ, are willing to make sacrifices, even of life itself (Mark 8:35).3s For the early Christians, institutionalized slavery was part of the social fabric and organization. The christological hymn of Phil 2:6-11, which describes Jesus as taking the morphèn doulou, would have had a far greater impact for the early Christians than it does

35 Based on these considerations the doulos vocabulary in the New Testament goes beyond symbolism by influencing the conduct of Christians towards others. In his discussion of Paul's attitude to slavery Peter Richardson understands the symbolic import of the concept to explain Paul's ambivalence and conservatism on the question of institutionalized slavery. For Richardson, "service not slavery was the point" (Paul's Ethic of Freedom. [Philadelphia: Westminster, 1979] 56). Yet in some sense Christians were enslaved: they were called to a radical subservience to the interests and claims of the other. 
for moderns because of the implications of the word doulos

at that time. A doulos could be coerced in ways which undermine many things that we who live in liberal democracies believe are important for human dignity.36

The Parameters of the Servant-Ethic in the New Testament

Much has been written by scholars on Jesus' role as a servant, Paul's self-styling as a slave of Christ, and the implications of texts such as the Haustafeln which give instructions to slaves in the form of general paranesis. These passages will not figure prominently in this discussion since we are concerned with the early Christian self-understanding regarding one's role as a servant/slave of others in the realm of ethics. Since the selfunderstanding of the earliest christians in relations with

36 In the West, this century has seen the consolidation of individual freedom as the highest political ideal. FoxGenovese and Genovese point out the opponents of slavery in the antebellum Southern U.S. believed that individual rights were universal. The defenders of slavery asserted, however, that individual rights were particular because "Individuals were good not in the abstract, but only as representatives of their kind and in their station" ("The Divine Sanction of the Social Order: Religious Foundations of the Southern Slaveholders' World View," in JAAR 55 [1987] 213). Also see Stephen Post, A Theory of Agape (Lewisburg: Bucknell University Press, 1990) 106-108, who notes that the ideal of individual freedom so extolled in the West has not been pursued so enthusiastically by all cultures. The idea is absolutely foreign to the New Testament communities. As Dodd says, "The New Testament gives no encouragement to the idea that the individual is self-determining or is an end in himself. He does not exist for himself" (Gospel and Law, 35). 
others is our focus, Jesus' understanding of his own role, Paul's understanding of his relationship to christ, and general paranesis concerning the behaviour of household slaves are only incidentally pertinent.

The requirement to place the interests of others first, or rather, one's own last, sounds a consistent note throughout the ethical considerations of the New Testament writers. For this reason this dissertation will not be a word-study of diakonos or doulos, but will embrace those passages which require the servant-ethic whether or not they use this vocabulary. Jesus' call to go the second mile is an example of the servant-ethic even though the words doulos and diakonos are not mentioned. The requirement to look to the wishes and interests of others and to eschew one's own rights even when they may be asserted justifiably, bespeak an attitude of servanthood, even slavery, which is thematic in New Testament ethics and is consistent with our definition of the servant-ethic. We can anticipate, therefore a diverse collection of passages that will be pertinent to our study.

\section{Disposition of the study}

The following study has as its primary objective the delineation of how fundamental the servant-ethic was to the self-understanding of the early christians by demonstrating that it occurs throughout the earliest christian documents. 
This objective will be fulfilled by examining the New Testament writings to discover the motives for, the content of, and the possible limitations upon, the servant ethic. The first chapter will examine the synoptic gospels in order to demonstrate that the evangelists record Jesus as paradigmatic and requiring a self-conscious stance of servanthood amongst $h$ is disciples. Texts that are especially important here will include Mark 10:42-45 and its parallels, parts of the sermon on the Mount and the calls to discipleship. The second chapter will be devoted to the Johannine literature. Here special attention will be paid to the footwashing episode of John 13 in order to show that, while in many respects the fourth gospel differs from the synoptics, the underlying sentiment regarding the selfawareness of Christians as servants of others is similar. The third chapter will examine the undisputed writings of Paul. It is perhaps in these writings that the servantethic is most explicitly elaborated. Chapter four will consider the remaining books so that we may perceive how consistent and persistent the servant-ethic is in the New Testament as a whole. The final chapter will conclude the study by summarizing its results and examining its implications.

This study does not seek to demonstrate that the ethics and the self-understanding of the early Christians were homogeneous or universally consistent. What it does 
attempt to show is that there was an element of consistency in what the New Testament writers understood about the selfawareness of Christians in their relations with others.

This self-awareness tempered Christian conduct, in theory at least, so that ambition, prestige and social status--in short, the interests of the self--were placed last out of obedience to the will of God. "For christianity, ethics are not self-contained or self-justifying; they arise out of a response to the Gospel."37 The servant-ethic is the fruit of a positive response amongst those who sought to put the message of the gospel into practice.

37 Dodd, Gospel and Law, 10. 


\section{THE SERVANT-ETHIC IN THE SYNOPTIC GOSPELS}

C.G. Montefiore says of Mark 9:35:

True greatness is service: service is true greatness. And not merely service but humble service. In the eyes of God the humblest may be the great. The servant of all and last of all may be in truth the first of all. A grand paradox.1

With these sentences Montefiore underscores the importance of serving others in the synoptic record of the teaching of Jesus. Putting oneself at the disposal of others and placing one's own interests last becomes an ethical ideal. While this requirement of self-denial and sacrifice is perhaps most succinctly stated in Mark 9:35 and in similar texts (Mark 10:43-44; Matt 20:26-28; 23:11-12; Luke 22:2427 ), other passages also invoke the same moral pattern. The synoptic gospels reveal a consistent call to renounce the interests of self even in situations where they may be asserted justifiably. The communities that perpetuated the traditions about Jesus clearly found something compelling and vital in such calls to serve others. We shall endeavour to identify the content, motives and limitations of this

1C. Q. Montefiore, The synoptic Gospels, I London: Macmillan, 1927) 217-218. 
requirement to serve that figures so largely in the synoptic record.

The content of the synoptic Servant-Ethic

The call to serve others is fulfilled in two separate steps in the synoptic gospels. First it can only be obeyed if an inner transformation through repentance has taken place in the hearer of Jesus' teachings. This is confirmed since the demand is made of disciples rather than being a part of Jesus' general proclamation (e.g., Mark 9:35; 10:4245; Luke 22:24-27). This repentance is primarily marked by a joyful turning to God and the repudiation of $\mathrm{sin}$ and disobedience. It is the discovery of the coming kingdom that compels an individual to surrender everything (e.g. Matt 13:44-46). As Günther Bornkamm has pointed out, repentance does not mean the performance of pious exercises before God in order to atone for sins committed. Repentance is the acceptance of God's invitation to salvation.2 "If Jesus' call to salvation is at the same time a call to repentance, the call to repentance is at the same time a call to rejoice."3 Or, as Ben Meyer puts it, "Repentance did not prompt God's mercy but attested it. It was joy and

2 Günther Bornkamm, Jesus of Nazareth (New York: Harper and Row, 1975) 82-84.

3 Jesus, 84 . 
thanks as well as tears, remorse, resolution." 4 The wholehearted response to God's offer of salvation and Jesus' call to repentance is thought to instill a willingness to put aside self-interest as the individual turns from self to God. The second step then involves putting into practice the concrete ethical action that is appropriate for those entering the kingdom. One of the cornerstones of such action is service to others. The call to take up one's cross functions as a warning to those who would become disciples of Jesus that such a decision to follow him inevitably will lead to self-sacrifice (Mark 8:34-35; Matt 10:38-39; Luke 14:27).5 While each of the three gospels portrays this sacrifice differently, they are all unanimous in the assertion that discipleship means placing the interests of others first in ways that are often arduous and difficult. Interestingly, the various strands of the servant-ethic that can be drawn out of the synoptic gospels are all marked by the paradoxes and hyperbole that, as scholars have noted, are so characteristic of Jesus'

The Aims of Jesus (London: SCM Press, 1979) 132.

${ }^{5}$ William Lillie notes that for Christians, self-denial becomes the essence rather than simply the means of the Christian life "when we see self-denial not as a matter of moral endeavour, but as the inevitable moral implication of the Cross of Christ" ("The Christian Conception of SelfDenial" in Studies in New Testament Ethics [Edinburgh and London: oliver and Boyd, 1961] 162). 
speech as recorded in these accounts. 6 we may identify four aspects of the content of the servant-ethic as it is depicted in these gospels.

I. Love of Neighbour

Love, by its very nature, involves a degree of selfsubordination on the part of the person who loves. An individual who loves another person often expresses that love by acts of service on behalf of the beloved, or by placing the interests of the other person before one's own. Most people have a store of anecdotal evidence that depicts heroic acts of self-denial on behalf of others, including the surrender of life itself, that individuals have performed on behalf of their "neighbours." In the synoptic command to love, therefore, we should expect to find elements of the servant-ethic.

The identity of one's neighbour and how one should go about loving that person are not neatly laid out in the gospels. The synoptic gospels are unanimous in their call to love of neighbour (Mark 12:28-31; Matt 22:34-40; Luke $10: 25-28)^{7}$, but only Luke gives a concrete example of what

${ }^{6}$ E.g., A. E. Harvey notes that in the gospels one of the characteristics of Jesus" teaching is "that a similar penchant for exaggeration [to that found in Proverbs] is pressed at times to the grotesque or paradoxical" (strenuous Commands: The Ethic of Jesus [London: SCM Press, 1990] 64).

7 For a full discussion of the command to love one's neighbour, including variations in the different synoptic texts, see Furnish, The Love Command in the New Testament (New York: Abingdon, 1972) 24-45. 
this means in the parable of the Good Samaritan $(10: 29-37) .8$

The lawyer's correct analysis that the one "who showed mercy" was the true neighbour to the robbers' victim offers a clue as to what this command to love entails.9 True love

B Robert Funk highlights the paradoxical nature of this parable and asserts that it cannot be classified as an example story because the 1 istener is not necessarily led to comport oneself as the Samaritan but can also be cast in the role of the victim (Parables and Presence [Philadelphia:

Fortress, 1982] 29-34). Nevertheless, the context of the parable makes clear that it is the Samaritan's conduct that is to be emulated.

9Kierkegaard ponders at length the question of the identity of the neighbour and concludes that it is incumbent upon the believer to become the neighbour. He concludes that the Samaritan's compassion does not show that the assault victim was his neighbour but that he was a neighbour of the one assaulted (Works of Love [New York: Harper Torchbooks, 1962] 38). Kierkegaard also finds reassurance in the notion of a command rather than simply a call to love one's neighbour. Love as a duty is protected from the foibles and preferences Kierkegaard finds so dangerous in friendship and erotic love (Ibid., 44). Although Kierkegaard here stands in apparent contradiction with Brunner (see above, 26), because he insists that Christian love is a duty while Brunner insists that true goodness and duty are incompatible, both affirm that christian love can only be practiced by those who have responded to the message of the gospel. Love commanded is required to view each neighbour equally without pausing to consider the inherent worth of a person as an object of love. As opposed to erotic love and friendship "the Christian teaching is to love one's neighbour, to love all mankind, all men, even enemies, and not to make exceptions, neither in favouritism nor in aversion" (Kierkegaard, 36). Love, then, is in part equal regard. The command to love is the requirement to ensure that the interests of others are served impartially. others have also considered these questions (e.g. Childon and MacDonald, Jesus and the Ethics of the Kingdom [Grand Rapids: Eerdmans, 1987] 94-95; Marshall, The Challenge of New Testament Ethics [London: Macmillan, 1946] 105). Also see windisch, The Meaning of the sermon on the Mount (Philadelphia: Westminster, 1951) 69-70, who dismisses the question of whether love can "be prescribed" as irrelevant. 
of neighbour is revealed, although not exhausted, by those who show mercy, who look upon the downtrodden, the beaten and the oppressed, and are moved into action to alleviate their suffering.10 While neither Mark nor Matthew include a parable akin to the Good Samaritan, Matthew, like Luke, include the "Golden Rule" with a note that "this is the law and the prophets" (Matt 7:12). The synoptic tradition understands love of neighbour to involve the capacity to empathize with the hapless circumstances of another, and the willingness to alleviate them. It involves assuaging the suffering of the hungry, homeless, naked, sick and imprisoned (Matt $25: 35-40$ ). 11

10 part of the irony of this parable, of course, is that it is a Samaritan who represents the ideal, and who recognizes his neighbour in the victim. The original saying about loving one's neighbour in Lev 19:18 makes the reader's fellow Israelite the object of the love. The samaritan, often scorned by many Jews in Jesus' time, replaces the Israelite in the familiar triad of priest, levite, Israelite, as Jeremias says (New Testament Theology [London: SCM Press, 1971] 213). The Samaritan understands the assaulted Jew as his neighbour. Also see fitzmyer, The Gospel According to Luke 1-IX (Garden City, New York: Doubleday, 1981) 878. In his interpretation of the parable Funk makes the inherent irony and paradoxes especially clear. Jesus" listeners undoubtedly "identify" with the robbers' victim initially until they become aware that it is a Samaritan who offers them aid--it is the enemy who serves (See again, Robert Funk, Parables and Presence, 29-34). For the victim the enemy becomes the neighbour because of circumstance and the Samaritan's human compassion. The victim, therefore, is in no position to refuse to be served.

11 Luke often displays a particular concern for the poor in his ethical injunctions; his emphasis upon the poor as one's neighbour will be considered below. 
Most important in this regard is the Christian understanding which is grounded in the gospel teaching that the neighbour is any other person and that person is to be loved unreservedly:

One's neighbour is one's equal. One's
neighbour is not the beloved, for whom you
have a passionate preference, nor your friend,
for whom you have a passionate
preference... . Your neighbour is every man, for
on the basis of distinctions he is not your
neighbour, nor on the basis of likeness to you
as being different from other men. He is your
neighbour on the basis of equality with you
before God; but this equality absolutely every
man has, and he has it absolutely.12

The command to love neighbours becomes a call to indiscriminate compassion towards others (Matt 5:46-47) which, by the very nature of love itself, often involves degrees of self-subordination and abandonment of selfinterest.

\section{Love of enemies}

The injunction to love one's enemies is, perhaps, the most radical directive that involves placing one's own interests last. In Matthew's sermon on the Mount there is a gradual build-up to the injunction that begins with $5: 25-26$ (the command to make friends with one's accuser), intensifies in 5:38-42 (the call to supersede lex talionis), and culminates with 5:43-48 and the bald demand to love one's enemies, and to pray for one's persecutors. This

12 Kierkegaard, Works of Love, 72 . 
passage concludes with the call to "be perfect (teleios), as your heavenly Father is perfect."

Matt $5: 38-42$ is an arresting illustration of what it means to subordinate one's own rights and interests. The command not to resist evil is illustrated by the example of offering the left cheek if the right is struck. As scholars have pointed out, the fact that it is the right cheek that is struck suggests that the blow is back-handed, which makes it doubly offensive.13 The blow is unjustified, and the disciple, rather than seeking to extract a fine mandated by such abuse (400 denarii, according to the Mishnah), is to offer the other cheek to the attacker. Justice, in the sense of defending one's rights, and the lextalionis, are thereby set aside.

Similar concerns are expressed by the example of Matt 5:40. The call to surrender one's cloak as well to the one who merely sues for one's coat, illustrates a deliberate effort to forego justice for oneself.14 The command

13 Manson (The Sayings of Jesus [London: SCM Press, 1949] 51) cites Baba Kamma 8:6. Also Jeremias, New Testament Theology, 239.

14 See Manson, 51. He cites Exod 22:25-27 and Deut 24:12-13 as examples in Jewish law which forbid forcing individuals to surrender their outer mantle, which also served as a blanket at night, if they failed to honour a pledge. Jesus, employing his characteristic hyperbole, however, insists that one's cloak also be given up, despite one's intrinsic right to its return at dusk. If followed literally, as scholars have observed, such a command condones nakedness. This is surely not, therefore, the intent of the passage. Since the text perhaps also hints, 
illustrates the principle that believers are not to seek their own rights but are rather to be prepared to radically surrender them a 11 .

The third example given in Matt 5:41 of going the extra mile follows in the same vein. Scholars understand this verse to reflect enforced conscription by the Roman army whose soldiers compelled civilians to carry their supplies and paraphernalia a certain distance.15 Jesus' followers are not simply to obey the soldiers of the occupation but are to exceed their demands. Again, the disciples' rights are to be abandoned.

While Mark does not include the commandment of Jesus to love one's enemy, Luke includes it in $h$ is sermon on the Plain with several variations (Luke 6:27-36). In Luke the command is repeated twice $(6: 27,35)$ bracketing specific examples of how the command is to be put into practice: doing good, blessing those who curse, praying for abusers, turning the other cheek, surrendering the inner as well as the outer garment, giving to all, lending with no

in light of 5:39, that the suit for the coat is itself unjustified, the issue is one of personal rights. As Davies and Allison affirm: "Jesus' hearers are being asked to give up their lawful rights" (The Gospel According to Saint Matthew I [Edinburgh: T. and T. Clark, 1988] 544). See also Ulrich Luz who says, "The logion means that one should not get involved in such lawsuits at all, and even as a debtor one should voluntarily give up even the minimum of the right of the poor" (Matthew 1-7 [Minneapolis: Augsburg Fortress, 1989] 326).

15 See Manson, 160; Davies and Allison, Matthew I, 547. 
expectations. Furnish notes the special focus the command to love has in the sermon on the Plain and that it has pragmatic connotations for the believer's life. It means the compassionate serving of whoever stands in need, active "doing good" even to one's enemies.16

Both Matthew and Luke point to the requirement to exceed the usual practices of the day and both conclude by insisting on a degree of perfection (in Matthew) or mercy (in Luke) that is similar to the Father's.17

Loving one's enemies in these texts entails forbearance in asserting one's rights: in essence it involves the waiving of justice for oneself.18 To love

16 Furnish, Love Command, 85 and 90.

17 For the meaning of teleios in Matt $5: 48$ see Davies and Allison. They conclude that "without doubt "moral perfection" is the meaning" in 5:48a (Matthew 1, 561). They note that love of enemy means "in effect, love of a 11.... And in this lies perfection: love of unrestrained compass lacks for nothing. It is catholic, all-inclusive. it is perfect" $(562-63)$.

18 This echoes Kierkegaard's insistence that love and justice must be understood to be in opposition. For Kierkegaard, there can be no reconciliation between love and justice. He calls love a "revolution" which necessarily disrupts justice and the

deeper the revolution, the more the distinction between mine and yours disappears, and the more perfect the love... The deeper the revolution is, the more justice shudders; the deeper the revolution the more perfect the love (Works of Love, 248-9).

A lso see C. Spicq, who says of Lk 6:29 that "Agape is... inseparable from renouncement and sacrifice. No one can love his neighbour as a Christian should unless he is 
one's enemies means that one refrains from returning

violence with violence (e.g. Matt 5:39; Luke 6:29), and from insisting on fair treatment at the hands of another (e.g. Matt $5: 40-42$; Luke $6: 29-30) .19$ Some have sought ways of

willing to give up his own pleasure, his comforts, and even his own rights" (Agape in the New Testament 1 [St. Lou is: Herder, 1963] 81). Outka, however, offers a full discussion of love and justice and a defense of the position that the two are often compatible depending upon the way in which one defines "justice" (Agape: An Ethical Analysis [New Haven: Yale University Press, 1972] 75-92). For another more "temperate" view that sees justice as a constituent of love, see stob, who notes that justice is an element of goodness not its totality. Since justice is "prior to and subservient to love" it should not be regarded in opposition to love because the two are harmonious. Justice rather is "to be distinguished from and contrasted to love, in order that it may achieve its own unique identity" (Ethical Reflections: Essays on Moral Themes [Grand Rapids:

Eerdmans, 1978] 124).

19 Similar attitudes are also found in Jewish texts from the turn of the era; for example, Joseph and Asenath (23:9; $28: 4 ; 12 ; 29: 3$ ) prohibits rendering evil for evil. This injunction to surrender one's rights sometimes proves problematic for modern liberation and feminist theologies. Actually it is often proffered by those who oppose such theologies. The focus of liberation theologians is the pursuit of justice in the belief that God's love should be recognized as available to all. This immediately recalls Kierkegaard's claim that love and justice are irreconcilable. One senses however that Gustavo Gutierrez is thinking along 1 ines very different from Kierkegaard when he promotes the view that theology has to serve the declaration of "the reign of love and justice." Love and justice are in the process of transforming history. Gutierrez says that "Liberation theology made this perspective its starting point as it attempted to show the meaning of the proclamation of the gospel for the history of Lat in America" (The Theology of Liberation [Maryknol1, New York: Orbis, 1988] xxxvii). In a similar vein, stob insists that social justice is necessary for love to operate: "Love has no free flow or passage where freedoms are limited. Love, it is clear, needs the presence of justice for it to operate" (Ethical Reflections, 138). According to the Sermon on the Mount, however, God "makes 
mitigating this injunction, for example, by describing this aspect of the synoptic ethic as somehow strategic; we shall consider this view of the motivation of the command for enemy love more fully below. Here we simply note that for many scholars the injunction to love enemies is understood to be a way of turning the enemy into a friend and thereby

his sun rise on the evil and the good, and sends rain on the just and on the unjust" (Matt 5:45). The call to love is seen as prior to any pursuit of justice. God's love extends to all, and is thereby paradigmatic for his people. such impartiality on the part of God is thematic in the Biblical and Rabbinic traditions. E.g. Wis 15:1-2; m 'Abod. Zar. 4.7 ; and $\mathrm{Ta}$ an. $7 \mathrm{a}$, which reads:

R. Abbahu said:

The day when rain falls is greater than [the day of] the Revival of the Dead, for the Revival of the Dead is for the righteous only, whereas rain is both for the righteous and for the wicked ( $J$. Rabbinowitz, trans.).

Also see H. Windisch, Meaning, 82-85, and G. Friedlander, Jewish sources of the Sermon on the Mount (New York: Ktav, 1969) 83. The problem hinges on how justice is applied to the ethic of loving one's enemies. Common sense dictates that it is better to struggle against an oppressor than to submit and allow injustice to affect others. Jesus, however, appears to leave not only retaliation but also the struggle itself to God. "Thus whatever our conception of justice, the 'better righteousness' invoked by Jesus requires the setting aside of one's own self-interest sometimes in situations of great injustice" (Davies and Allison, Matthew, 1, 508-09).

In a sense, as far as justice is concerned, Jesus does not supersede the lex talionis, but rather stops short of it. Vengeance will occur but in an eschatological rather than immediate context. To be sure the wicked do prosper, often at the expense of the godly, but as the writer of Ps 73 makes clear, true refuge is found in God whose mercy and justice will eventually restore the balance. Jesus encourages his followers to trust that this is the case. As Davies and Allison say, "The law of reciprocity is not utterly repudiated but only taken out of human hands to be placed in divine hands" (Matthew 1, 540). 
overcoming the problem of oppression, persecution and injustice.

III. Service to the poor

While Luke has a special interest in the poor and the Christian's responsibility towards them, the synoptic tradition as a whole reflects this concern. Concerns about earthly possessions are to be disregarded in favour of alleviating the suffering of the poor. As Birger Gerhardsson says of Matt 5:17-48 "'overflowing' obedience toward God comes to expression in a sacrificial, generous attitude toward one's fellows... When one loves God with one's whole heart...people are beneficiaries."20 There are three passages that we shall consider to illustrate this: Matt 25:31-46; Luke 14:12-14 and Luke 16:19-31.

In the first of these Jesus describes the eschatological judgment that awaits those who fail to offer concrete acts of service to the poor, or more specifically the hungry, the thirsty, the stranger, the naked, the sick and the imprisoned. Many scholars believe that the "poor" are Christians and that the audience of Matthew's gospel is being reminded to live up to their responsibilities towards their fellow-believers. The primary grounds for this view are founded upon the references to prison visitation (unusual in a list of "works of love") which are thought to 1981) $\frac{\text { The }}{48}$

20 The Ethos of the Bible (Philadelphia: Fortress, 
refer to Christians incarcerated for their faith.21 lt is also possible, in view of other statements of the Matthean Jesus, to see here a reference to the impoverished in general (Matt 5:43-48).22 Nevertheless, the fact that the possibility is envisioned that some members of the Christian community will fail to carry out such service to the poor suggests that not all members of the community are living up to their calling as servants of others.23 in this passage to serve the poor, whomever they might be, is to serve the son of man himself.

In Luke 14:12-14 Jesus tells the Pharisee who has invited him for a meal that he should invite the poor, destitute and maimed rather than his friends, family and rich neighbours to his banquets since he can expect no reciprocity from the former. In this way the host can expect to be blessed at the resurrection. In this passage

21 See Harvey, strenuous Commands, 188.

22 Harvey explicitly rejects this latter interpretation. The suffering individuals whose need the Christian is to respond to are themselves believers. In their need they have become agents of Christ. "The way one treats the followers of Jesus is a matter which incurs the highest commendation or the severest judgment of God" (strenuous Commands, 188).

23 The possibility exists that the "goats" are simply outsiders to the Christian community and that this passage illustrates that believers are always found to be engaged in serving the destitute. Such an interpretation stretches the 1 imits of credulity since Matthew himself recognizes that outsiders are capable of alms-giving (e.g. Matt 6:2), and that some who call Jesus "Lord" will not enter the basileia $(7: 21-23)$. 
Jesus reveals that generosity is of no value, in eschatological terms, if it is displayed with expectation of imminent benefits for oneself. The prominent Pharisee should not seek what fitzmyer terms "selfish recompense" but should display real love "which never reckons with recompense; and because this is so, generosity will find its reward at the resurrection." 24 The reward for such generous service is not to be sought in subsequent invitations to elegant and grandiose parties but rather in the hope of the approval and blessing of God.

In Luke 16:19-31 the eschatological implications of failure to provide even the slightest service to the suffering poor are driven home with the striking parable of the rich man and the beggar Lazarus. As Fitzmyer points out the rich man's lack of concern for the beggar is only implied,25 but the reader infers from the judgment upon the former that he deliberately withheld even his crumbs from Lazarus. 16:13 anticipates the parable as Jesus insists that one cannot serve God and be a lover of riches.26 Luke does not say that the rich necessarily stand condemned but the story forcefully contends that wise use of wealth includes generous provision for the poor. The conclusion of

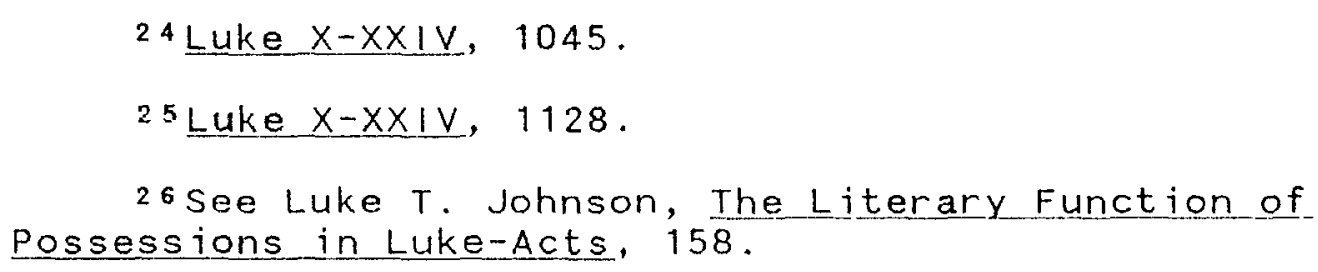


the story reveals that for those whose hearts are hardened against God, and therefore against the suffering of others, even the testimony of one who has been resurrected will not change them. 27

The disciple's empathy with the impoverished should arise naturally from the change of heart that taking up one's cross entails. As Gnilka says:

Man soll sich der Verachteten annehmen. Statt selbstsüchtig nach Vorteilen zu streben, soll der Jünger sich vergessen und dem Unterprivilegierten helfen, nicht von oben herab, sondern so, dass er ihn, wie Jesus das Kind, liebend in die Arme schliesst.28

That service to the poor is not in and of itself adequate, however, is starkly reflected in the synoptic writers' accounts of the anointing of Jesus by a woman (Matt 26:613; Mark 14:3-9; Luke 7:36-38). In Matthew the disciples object to the extravagance, claiming that the profit from selling the ointment could have been given to the poor. In Mark the reaction is much the same, although the word mathetai is not used. In both these accounts Jesus responds by suggesting that the anointing is a "beautiful thing" and that it involves preparation for his burial. He then reminds his listeners, "You always have the poor with you,

27 There is here an unmistakable reference to the resurrection of Jesus.

28 Das Evange lium nach Markus II (zurich, Einsiedeln Köln: Benziger Verlag, 1979) 58. 
and whenever you will, you can do good to them; but you will not always have me" (Mark 14:7).29 There are always opportunities to give and to help others, service which in the synoptic tradition also constitutes giving to and helping Jesus, but the occasions for extraordinary displays of service to Jesus himself are rare indeed.30 The story

\footnotetext{
29Matt 26:11 reads: "You always have the poor with you, but you will not always have me." This is much more brusque than the Marcan account, but also suggests that the disciples will have plenty of opportunity to serve the poor. The irony of the passage in Mark, of course, is that immediately following this episode we read of the betrayal of Jesus by Judas (Mark 14:10-11): the woman's loyalty and loving extravagance become foils for Judas' treachery and greed (Schrage, Ethics, 72-73). Luke, however, has edited the passage considerably, most notably by omitting the saying about the poor. He also sets the episode in the home of a Pharisee named Simon in Galilee, rather than of Simon the Leper in Bethany. Instead of a harbinger of Jesus' burial the passage becomes an illustration of Jesus' power to forgive sins accompanied by the parable of the creditor. Luke has attempted to completely eradicate any traces of indifference to the poor on the part of Jesus. Fitzmyer believes that Luke was using a completely different tradition for this episode than either Matthew or Mark (Luke $1-1 X, 686$ ). Raymond $E$. Brown suggests with others, that two incidents in fact took place, one in Bethany and one in Galilee, and that the two stories have been conflated by oral tradition reflected in the Lukan account (The Gospel According to John $|-x| 1$ [New York: Doubleday, 1970] 449-54). Whatever his source, and assuming. Luke knew Mark at least, his account reflects, in my opinion, a desire to prevent his readers from inferring that Jesus was indifferent to the sufferings of the impoverished.
}

30 Jeremias helps to explain the attitude of Jesus in Mark 14:3-9 by recalling the distinction early Judaism made between almsgiving (zadaka) and "works of love" (gemiluth chesadim). According to Jeremias, there were three characteristics of this distinction: Alms were directed towards the poor, the living, and were donations of money; whereas works of love were undertaken on behalf of the poor or the rich, the living or the dead and were either 
reveals, therefore, that service and self-denial, in and of themselves, are not adequate; true service to others proceeds from serving God, or at least must not replace it. Finally, in the passage about the rich young man (Mark 10:17-22; Matt 19:16-30; Luke 18:18-30), both Matthew and Mark, as well as Luke, illustrate that service to others is demonstrated in concern for the poor. Jesus' love to the man (Mark 10:21), at least in Mark, is demonstrated by the observation that the man lacks one thing: "Go, sell what you have and give to the poor and you will have treasure in heaven."31 self-denial by giving to the poor is the

donations or acts of service. Works of love are therefore superior to almsgiving ("Die Salbungsgeschichte Mk 14:3-9" in Abba [Góttingen: Vandenhoeck and Ruprecht, 1966] 109110). In $\vee .7$, then, Jesus does not see himself as more worthy than the poor but rather explains the woman's "work of love" as superior to almsgiving (ibid., 114-115).

31 In Matthew the man asks "What do I still lack?" Jesus responds, "If you would be perfect, go sell what you possess and give to the poor and you will have treasure in heaven; and come, follow me." Two things recall earlier episodes in Matthew that we have considered. First, the reference to being perfect reminds the reader of Matt $5: 48$, and the challenge to be like God (Rudolf Schnackenburg. The Moral Teaching of the New Testament [London: Burns and Oates, 1975] 108-109). Luz notes that Matt 19:20-21 may be seen to stand in tension with $5: 48$ since in the former simple renunciation of possessions may be seen to lead to perfection. He rightly asserts, however:

This tension can be bridged if one recognizes that perfection is for Matthew a task which all Christians face and which motivates all. The righteousness, which is greater...than that of the Pharisees and scribes, includes in its quantifying element the possibility that different Christians can variously advance far on this way. But the goal is the same for 
prerequisite, in this case at least, to acquire heavenly treasure.32 Jeremias sums up the attitude towards material possessions by saying:

For all the disciples of Jesus, regardless of whether they leave everything and accompany Jesus or remain in their homes, it follows that by experiencing salvation they have been shaken out of the security of their possessions (Luke 19.8). They have experienced a revision of all values.... Possessions become elachiston, a bagatelle (Luke 16.10). This elachiston is contrasted with the alethinon, the true possession ( $v .11)$, salvation. In this process of the revision of values, earthly possessions become not only elachiston, but also allotrion ( $v .12$ ), an alien property the administration of which is entrusted by God. The person who restores it to God through the sacrifice of love is the one who administers it rightly.33

a $11 \ldots$ In this sense, Matthew is definitely a perfectionist (Matthew 1-7, 347).

Second, the demand to "follow me" parallels Matt 16:24, so that denying oneself and taking up one's cross can be read as equivalent to surrendering one's possessions on behalf of the poor. The Lukan parallel also reflects special interests. In Luke 18:18 the man is referred to as a ruler (archōn), one who is not only rich, but also enjoys political power.

32 But note Harvey's comment: "The motivation of giving alms is always the good of the donor, never the relief of poverty" (Strenuous Commands, 136). Jeremias insists that total surrender of one's possessions is restricted to those who actually accompany Jesus.

Zacchaeus, for example, only gives away half of what he owns $(222-223)$. (The Essenes also called for individuals to surrender their material goods upon entering the community [1QS 6:19-20;22;24-25]. See Schnackenburg, Moral Teaching, 124 , concerning attitudes at Qumran towards property and the title "the poor.")

\section{New Testament Theology, 223.}




\section{Rejection of social hierarchies}

This "revision of values" of which Jeremias writes ${ }^{4}$

is also reflected in the attitude that disciples should have toward social hierarchies and political power structures. In endeavouring to fulfill one's obligations as Jesus' disciple, an individual must not look for recognition and honour, but rather seek the least prestigious position and become a servant. Thus a disciple is required to renounce the lust for power and the temptation to pursue it within the community. This is a persistent theme in the synoptic gospels and is indicated by the calls to become as a child or a servant (Matt 18:2-4; 19:4; 20:25-28; Mark 9:35; 10:15; $10: 42-45$; Luke $9: 48 ; 18: 17 ; 22: 25-27$ ), and to become last of a11. These sayings represent a corrective of human ambition that is to be adopted by those who would follow jesus. The community is to be made up of individuals who place their own interests last so that even the leaders are servants of the least. Jesus is himself paradigmatic of this: he represents the true servant (Mark 10:42-45) and is symbolized even by a little child (Mark 9:37). As Allen Verhey observes, by responding to Jesus' message individuals also respond to the coming kingdom in which the order of first and last is to be reversed. "To welcome the coming of

$34 \mathrm{Dr}$. B. Meyer has kindly pointed out that the original German text of Jeremias' work uses Nietzsche's phrase Unwertung der Werte, better translated perhaps as the "transvaluation" or "revaluation of values." 
such a kingdom is to welcome Jesus, and... joyfully to surrender the rights and privileges of social status and convention and to serve." For Verhey, humble service "is a part of the concrete shape of repentance in view of the coming kingdom and its present effectiveness in Jesus." 35 We find this ethic specifically invoked in the calls to reject prestige (e.g. Matt 23:8-10; Luke 14:7-11), whereby Jesus' followers are to be indifferent to the honours that social reputation brings. In this way human ambition, which by definition is at odds with God's kingdom and rule, is corrected. 36

The pervasive use of the servant metaphor powerfully conveys this theme. Social conventions and customs that arbitrarily lend more prestige to some than to others based on wealth, learning or ancestry are rejected in favour of the dominion of God. In a sense, this teaching is subversive in that it makes counter-claims to the 17.

${ }^{35}$ The Great Reversal (Grand Rapids: Eerdmans, 1984)

${ }^{36}$ See Schnackenburg, Moral Teaching, 115-117. Of Mark $10: 42$ and its parallels he says:

It is not a fundamental repudiation of political institutions, but a statement based on observation. But Jesus sees what is dangerous and seductive in power (116).

of Matt 20:26-27, he notes that the saying reflects the different order that obtains amongst Jesus' followers which rejects legal justice. The saying "does not deny all value to power... but the disciples of christ must be prepared to renounce it with a view to the kingdom of God" (116). 
requirements of social protocol.37 Those with the least rights in society, slaves and children, provide the model for Jesus' disciples. The disciples are to become ones who serve, who no longer seek their own advantage but rather endeavour to minister to others.38

${ }^{3} 7$ Lohfink, commenting on Mark 10:42-45, notes the text's inherent rejection of "structures of domination" which are not permitted in the new family of God. "Jesus, in other words, demanded of his disciples a completely new type of relationship with each other, something not otherwise typical of society.... He required a contrastsociety" (Jesus and Community [Philadelphia: Fortress, 1984] 49, emphasis his). Luz detects a similar viewpoint in Matt 5:38-42 and the attitude required toward outsiders and enemies. He notes that the sayings are not simply an objection to dehumanizing force, but also demand active conduct. "In them is to be found a gentle protest and an element of provocative contrast to the force which rules the wor 1d" (Matthew 1-7, 327-28).

38 In their book Jesus and the Ethics of the Kingdom, Bruce Chilton and J.H. MCDonald see much affinity between the two models of paidion and diakonos:

The "paidion" archetype in the Gospels transcends the limits of the "child" archetype and shades into the connotations of the servant....Appeal is made to the "servant" symbol partiy because it expresses the antithesis of power, status and dominations and the destructive drive; and partiy because it suggests realization of human potentiality through acceptance of others and the building of community. It operates through a model of self-giving...not as exaggerated selfdeprecation but as reaching out to others in neighbour love. Here is the dynamic of the new creation, representing the outworking and therefore the essential complement to the "child" symbol: it is a uniting, even redemptive symbol, turning the loss of "dying" into the gain of life renewed (88-89). 
The inclination to serve, to put the interests of others first and to refrain from self-assertion, comprises a major theme in the synoptic record of Jesus' teaching, and also reflects the concrete response to the various commands to love. To cite Furnish's words, "service' not 'security' is the watchword of this ethic."3s

\section{The synoptic Motives for Serving others}

Disputes about greatness amongst the disciples sometimes form the context for Jesus' call to serve others (Mark 9:33-35; 10:35-45; Matt 20:20-28; Luke 22:24-27). In each of these passages squabbling amongst the disciples precedes Jesus insistence that service to others rather than personal ambition is required of his disciples. Because different emphases can be detected in each text we will consider each gospel in turn rather than using the topical arrangement in the previous section.

\section{Mark}

In Mark 9:35 the disciples of Jesus have made a decision to follow him and, according to Mark, have already been told that their choice requires self-denial (Mark 8:3438). Jesus now telis them, in Mark 9:35, that this selfdenial, as we saw above, is, in part, to take the form of

\footnotetext{
39 Love Command, 69.
} 
concrete service towards others.40 The phrase "If anyone would be first" (Ei tis thelei protos einai), can be interpreted two ways. Either the desire to be first is affirmed as good, but Jesus insists that the goal be achieved through service; or the desire to be first, and personal ambition as a whole, is seen as evil and must be set aside if a person truly is to follow Jesus. Vv 36-37 offer the strongest clue that the call to serve is a corrective to such ambition, at least in this gospel. In these verses Jesus insists that the disciples welcome or receive a little child as if they were receiving Jesus himse $1 f$.

40 While some have suggested that the child here represents the "weaker members of the community" (e.g. Taylor, The Gospel According to Mark (London: Macmilian, 1953) 405, or personal emissaries of Jesus, (e.g. Lane, The Gospel of Mark [Grand Rapids: Eerdmans, 1974] 341), it makes more sense for the paidion to be understood simply as a child, who, in the kingdom proclaimed by Jesus, represents an ideal (e.g., Mark 10:14-16). All children, all people, are to be welcomed as if they were Jesus himself (not simply children or "weaker disciples" who come in his name):

11 n'est pas dit qu'ils viennent au nom du Christ, en onomati, mais qu'on les recgit epi tói onomati, c'est-à-dire "en vue de, en l'honneur de" (Lagrange, L'Evangile de st Marc [Paris: Libraire Lecoffre, 1966] 246).

Thus the call to serve in $9: 35$ seems to reject ambition. It is to be replaced by an attitude that looks to others in a way which ignores those social conventions that suggest some people (children) are unworthy of attention. By welcoming such individuals as one would welcome Jesus one reveals a readiness to serve. 
In Mark 10:42-45 the impetus for such an ethical

stance becomes even stronger. Here a self-conscious posture against emulating the methods of those who rule over the Gentiles is part of the motive. Those who are considered "great" by the Gentiles exercise authority. This, however, is not to be part of the disciples' self-understanding. Rather they are self-consciously to thwart personal ambition and the desire for dominance over others by becoming servants of all and last of all. Jesus challenges the disciples' ambitions and seeks to correct the attitude that lies behind the request of James and John in $v .37 .41$

411 believe it is too cynical to assert that servanthood is portrayed as the means to attain greatness; i.e., that for those who become servants Jesus promises them the personal glory they are vying for. Dan Via Jr, however, comes close to stating this when he says that "well-being (being great or first) is present as the object of will and, by implication, as the intentional reason for human action." He continues that one attains this wellbeing by becoming a slave of all and that 10:43-44 "expresses the ethical actualization of the faith stance ( $8: 35$ )" (The Ethics of Mark's Gospel: In the Middle of Time [Philadelphia: Fortress, 1985] 158-59). I think more caution is required here. Human conventions concerning greatness no longer apply, yet the language of greatness is still employed to illustrate the consequences of faith. This is the paradox of the servant-ethic: the transformation of the human heart impelled by responding to Jesus' call makes such categories as greatness irrelevant, yet they are used metaphorically to illustrate the outcome of faith and discipleship. Gnilka overcomes the paradox in part by pointing to greatness in service here:

Wer in ihr nach Rang und Vorsitz strebt, soll seinen Dienst wie ein Diener und Sklave tun, sich nicht von Ehrgeiz, sondern von Dienstbereitschaft leiten lassen (Markus 11 , 103 ). 
The example of Jesus himself also figures as part of the motive in this passage. Following his insistence upon an extreme degree of service to others he says that it is required because "the son of man came not to be served but to serve and to give his life as a ransom for many" $(10: 45) .42$ The pursuit of selfish ambition and social prestige is to be set aside, deliberately and selfconsciously, after the manner of the son of man.

While other passages in Mark express similar ethical concerns, variations in motive can also be detected. In Mark 8:34-35, for example, self-denial and taking up one's cross is encouraged on the grounds that it is by losing one's life for the sake of Jesus and the gospel that one ultimately saves it. In the context of this passage Jesus lays out the conditions of discipleship, conditions that always involve self-sacrifice. The motive for such sacrifice is that it is the means by which one's "life" is "saved."43 The sacrifice spoken of here does not refer only

42 on diakonos and its occurrence in Mark 10:45, Gnilka notes that the word does not yet have connotations of authority and is grounded in the service and atoning death of the son of man (Markus, 11, 103). As we shall see, Jesus' exemplary role constitutes a large part of the motive for the servant-ethic throughout the New Testament. For a discussion on this point with specific reference to the gospel of Matthew see Birger Gerhardsson, "Sacrificial Service and Atonement in the Gospel of Matthew" in Reconciliation and Hope (Grand Rapids: Eerdmans, 1974) 25-35.

$431 t$ is perhaps important to note here that there is no mention of glory in this passage until v.38c, and that there is no explicit mention of reward (unlike the Mathean 
to the crisis of martyrdom, although some see this as the correct interpretation of the passage, 4 but rather to a consistent denial of one's own interests. Ernest Best prefers to interpret the passage metaphorically. He points out that persecution rather than martyrdom is a more prominent motif in the New Testament as a whole, and that the idea of self-denial in the Markan text points away from a literal understanding of the verse. For Best the implication of cross-bearing is the willingness to sacrifice anything, including one's own life, for Christ. "Selfdenial is the inner attitude; cross-bearing is the outward activity which should accompany the inner attitude."45 Best concludes that because taking up a cross corresponds to a particular event in Jesus' own life there is clearly a call to imitation in this passage. "That the disciple's cross-bearing need not be literal as Jesus' was does not

parallel in 16:27).

44 Ernest Best cites Haenchen as one who insists that the passage refers to martyrdom based on the aor ist verbs aparnésasthō. and aratō in 8:34 (Following Jesus:

Discipleship in Mark [Sheffield: JSOT, 1981] 50, n.67). Also see W. Lane, The Gospel According to Mark, 308-9.

45 Best, 39. He also notes that Luke definitely understands the saying to be metaphorical because he inserts the word "daily" at Luke 9:23 (ibid., 38). 
affect this since Jesus' cross-bearing is symbolic of all his loving activity." 46

Another important text that might help illuminate the motives of this requirement to serve is Mark 12:30-31, the love commandment. A scribe asks Jesus to name the greatest commandment. Jesus replies by iterating the oneness of God and that one should love him completely. He then says, "You shall love your neighbour as yourself" (Agapēseis ton plēsion sou hōs seauton) and that there is no commandment greater than those requiring love of God and

46 Best, 39. The call to follow Jesus requires different obligations of those who respond, according to Martin Henge l, than those obligations incumbent upon those who simply answer the call to repentance. The former involve specific individuals, who took on special roles as followers of Jesus, whereas the demand for repentance was required of everyone. Everyone needed to repent and acknowledge their guilt before God and subsequently fulfill his will in acts of love. Those who repented had to renounce "all self-glory and all pious claims on their Father in Heaven, and to will unconditionally to practice forgiveness of their neighbour, in response to the uninvited forgiveness, through God's goodness, of their own immeasurable guilt" (The Char ismatic Leader and his Followers [Edinburgh: T. and T. Clark, 1981] 61). Although historical considerations compel us to see the circle of disciples as a group distinct from the numbers who responded to the message of salvation, in terms of the early Christian ethical understanding the distinction becomes less important. Bornkamm acknowledges "that the disciples must be distinguished as a more intimate group from Jesus' followers in the wider sense" but insists that "what he [Jesus] demands from them does not in fact differ from what he asks of everybody: to repent in light of the coming kingdom of God" (Jesus of Nazareth, 147). In the postEaster communities the passages about the call to follow were surely interpreted as a summons to faith in Christ, as Hengel says (62). After Easter, those who follow Jesus are those who serve God and neighbour. 
neighbour. In praising Jesus' response, the scribe also provides part of the motive for loving one's neighbour as oneself: it "is much more than all whole burnt offerings and sacrifices." such rituals are pleasing to God, and imperative according to Torah, yet to love God, and others as oneself, is even greater. This judgment is confirmed because the scribe's insight and wisdom prompt Jesus to tell him that he is not far from the kingdom of God. Here, then, the motive boils down to the confirmation that a better way than ritual worship to honour God, is not only to love God, but to love one's neighbour also.47 Those who desire to

47 am not suggesting here that the author of Mark, or any of the New Testament writers for that matter, would suggest that love for neighbour can substitute for love for God in a Christian context. As Furnish says:

Loving the neighbour is no less an act of obedience than loving God and is part of the total response to the sovereign claim of God under which man stands. One's response to God--setting aside self-will, renouncing one's own claims--is to be paradigmatic for one's relation to his neighbour (Love Command, 63, emphas is his).

Further, as Birger Gerhardsson makes so clear in his essay "Sacrificial Service and Atonement in the Gospel of Matthew," service to God (latreia, Matt 4:10) is inextricably tied to service to others: "In the final judgement 'deeds of mercy' are asked after (25:31-46). Diakonia is counted as latreia" (32). Although the ones counted as sheep rather than goats are unaware that they have served God by serving others (Matt 25:37), the implication of the passage suggests that it is their desire to fulfill God's will that led to their self-understanding as servants of others. Jesus is the exemplar of how diakonia counts as service to God. Matt 20:28 (Mark 10:45 par.) reveals that Jesus' crucifixion is not simply sacrifice in the sense of atonement, but is sacrificial 
serve God must also be willing to love their neighbour as themselves. 48

A final motive that we should consider is the calculated strategy to repudiate, at least amongst Jesus' followers, the order of things as they currently stand. Thus, Jesus' disciples are not simply to avoid behaving like the rulers and authorities of the Gentiles--they are to take deliberate steps to become the exact opposite, to become diakonoi and douloi.49 While some have accused the Markan community of attempting to "retreat from the world

service to others (See Gerhardsson, "Sacrificial Service," 30 ).

48 Jesus declares in Matt 22:40 that the law and the prophets "depend on" the commandments to love God and neighbour. The "Golden Rule" perhaps goes a long way in explaining the command to love one's neighbour as oneself. which has caused much scholarly discussion (E.g. A. Nygren, Agape and Eros [Chicago: University of Chicago Press, 1953], 100-101, 217; G. Outka, Agape: An Ethical Analysis, 55-74; R. Schnackenburg, The Moral Teaching of the New Testament, 103-104; W. Schrage, The Ethics of the New Testament, $79 ; \mathrm{L} . \mathrm{H}$. Marshal1, The Challenge of New Testament Ethics, 106-7 and R. Bultmann, Jesus and the Word [New York: Charles scribner's Sons, 1958] 115-120.) In the context of Jesus' ethic as a whole, as presented in the synoptic texts, these words probably convey the same meaning as the "Golden Rule." To love others as oneself is to love them and treat them as one wishes to be treated. C. S. Mann highlights this understanding of the phrase with his call to translate "agape (given the current debasing of the word 'love' in contemporary English) [as] "sacrificial compassion" " Mark [Garden City, New York: Doubleday, 1986] 481).

49 This inversion is illustrated, for example, by Mark 10:14-15 in which Jesus welcomes the little children and encourages $h$ is followers to receive the kingdom hōs paidion. 
and its problems,"50 Verhey suggests that Jesus" call to serve points rather to the creation of a "counterculture" which exists in contrast to both the religious and civil establishment:

The contrast between Mark's community and the civil authorities is to be effective not in revolution but in a new and different understanding and exercise of power within the community....(Mk. 10:42-45). It will hardly do to call this a "retreat from the world and its problems." It is rather an heroic effort in the midst of opposition to demonstrate and participate in God's reign--even politically.51

As Wolfgang Schrage has pointed out, the theme of discipleship is central to the Marcan record.52 This is reflected in the motives we have discovered when considering the Marcan call to serve others. Jesus' followers are not to pursue ambitions of dominance over others, nor are they to aspire to personal greatness on their own behalf. The call to serve in Mark is motivated by a desire to emulate Jesus, to honour God and thereby reject norms and mores that lead to arrogant self-seeking. In other words it is

$50 \mathrm{E} . \mathrm{g}$. , Jack T. Sanders says:

Regarding how the christian was expected to relate to his fellow Christian Mark has almost nothing to say; presumably he conceived of that as no problem since Christians for the most part simply drew together against the wor $1 d$ and in anticipation of the Lord's coming (Ethics, 33).

51 The Great Reversal, 77.

52 Ethics, 141. 
motivated by a desire to realize full discipleship in the Jesus movement. 53

\section{Matthew}

In Matthew, although many of the pertinent passages are parallels to those we have considered in Mark, the increase in material and varying contexts also mean that often a different motive is envisioned in the calls to serve others. When considering the requirement to $p$ lace the interests of others first we also have to examine certain portions of the sermon on the Mount that are relevant to our study.

For those passages which have parallels in Mark many of the motives are similar in Matthew. Matt 20:25-28 (which parallels Mark 10:42-45) is almost identical to its Marcan parallel in wording. The primary difference is that it is the mother of the sons of Zebedees4 who makes the request for their prestigious position in the kingdom and thereby gives the impetus for Jesus' saying.55 Minor differences

$$
53 \text { of course, the disciples also believed that by }
$$
following Jesus and being open to self-sacrifice they would "save" their "lives" (Mark 8:34-35) but in the Markan record the theme of reward is not developed explicitly as it is in Matthew.

54 James and John are not named in Matthew.

55 Most commentators agree that the fact it is the mother who makes the request reveals that Matthew is trying to tone down the unflattering portrayal of James and John in Mark. Albright and Mann disagree, however: "The suggestion is interesting solely as an example of ignorance of the ways and manners of mothers anxious for their sons [!]" (Matthew 
aside, Matthew's account of this incident seems to provide similar motives to those we have suggested can be found in Mark 10:35-45. Jesus seeks to thwart personal ambition in favour of an attitude of willingness to serve others even unto death. His disciples must not assume that the kingdom of God emulates worldly hierarchies or political regimes. This rejection by Jesus of the order of the day is also reflected in Matt $23: 1-12$. Much of this passage is bound up with a ringing condemnation of the "scribes and Pharisees" for which little direct parallel material is found in Mark56. This critique of the Pharisees serves, however, as a contrast to the correct attitude that must be found amongst Jesus' disciples. Unlike the scribes and Pharisees, who "love the place of honour at feasts and the best seats in the synagogues," Jesus" disciples are not to covet places of honour or prestigious titles.57 The one who is greatest among them shall be their servant and only those

[Garden City, New York: Doubleday, 1971] 241-242). They have to acknowledge, however, that Jesus' reply is addresed to the sons of Zebedee themselves and solve the dilemma by assuming that Matthew knew both traditions.

56 But see Mark 12:38-39. I do not want to suggest that Mark is innocent of condemnation of the Jewish religious establishment.

57 The reference to the "place of honour at feasts," as well as having a direct parallel in Mark 12:39 and Luke 20:46, recalls the synoptic injunction to serve rather than to seek a prestigious position at banquets, especially the eschatological banquet prepared by God (e.g., Luke 14:7-11; $22: 26-27$ ). 
who humble themselves will be exalted. As well as seeking to correct personal ambition, this passage also makes

explicit the promise of exaltation for the humble. While we need not suggest that this is the primary motive for serving others in this passage, we must not shrink from the fact that the Matthean Jesus offers it as a consideration in promoting appropriate behaviour.58 in this passage, then, Jesus' followers are called to humility and service so as to avoid the ambition and arrogance of some of the religious authorities, and thereby gain exaltation by God.59

5 a Schrage insists that "it would be wrong to interpret Matthew simply as an exponent of a spirituality based on merit" (Ethics, 151). This is true since the grace of God is certainly apparent in Matthew. Nevertheless, in these and other verses, reward constitutes part of the motive to serve. In his interpretation of $v .12$, Klaus Wengst completely steers clear of the issue: "The fact that the saying about humiliation and exaltation in $v .12$ brings this passage to an end makes it clear that it refers to fellowship with in the community" (Humility: Solidarity of the Humiliated [Philadelphia: Fortress, 1988] 41). For Wengst all the New Testament passages which mention humility point to a desire to unify the community against adversity. Both seem reluctant to acknowledge the clear promise of reward to those who behave appropriately.

59 It is important to remember that the exaltation of the humble is a prominent theme throughout the biblical tradition. The people of God are repeatedly reminded that despite their lowly status they can look forward to ultimate exaltation and vindication (e.g., Prov 3:34; 11 Sam 22:28; Ps 18:27; Job 5:11), although in many of these examples the lowliness or humility of God's people is a pre-existing condition and not one which is deliberately sought. The issue is whether one seeks reward from other people or from God--whether one chooses to be esteemed by others or to seek the exaltation that only God can give. In this Matthean passage Jesus' followers are called to eschew any impressive appellations that may be bestowed upon them, as well as other honours, secure in the assurance that they 
Reward as a motive for responding to Jesus' call to serve is also apparent in the sermon on the Mount. Again, it is not, perhaps, the primary impetus for making the interests of others paramount, but it is there.60 The Matthean Jesus calls his followers to exhibit much behaviour that goes beyond religious norms and expectations. As far as Jesus is concerned divorce and oaths are prohibited $(5: 31-37)$, every outburst and look of lust is condemned $(5: 21-22,27-28)$ and those at odds with their "brother" must be reconciled before they approach the altar (5:23-24).61 More significantly, as we have seen,

will be duly exalted. The context of the call is the grace that God has seen $f$ it to bestow upon them and their gratitude for it. They must come to the realization that no one has a strict claim on God.

60 it is interesting to note that Mark, which many consider to be devoid of any real ethics, also is far less interested in notions of reward. For example the Markan parallel to Matt 16:27 (Mark 8:38) is less explicit than Matthew concerning how the son of man will "repay every man for what he has done." Verhey notes that Matthew "sometimes makes "entering the kingdom" (a phrase used more often by Matthew than by any other New Testament author) contingent on doing the righteousness required in the sermon ( $5: 20$; $7: 21$; but see 21:31) (The Great Reversal, 90). Throughout the New Testament a standard of righteousness is required of those who would remain within the community. The servantethic stands as a primary characteristic of that standard. This does not mean that fulfillment of the servant-ethic alone is adequate to practice true righteousness.

61 This recalls the scribe's response to Jesus in Mark $12: 33$ in which the love of God and neighbour is deemed "much more than all whole burnt offerings and sacrifices. "There is, however, no parallel for this latter saying in Matthew, perhaps because he is more reluctant than Mark to portray Jesus as supplanting Torah (e.g. Matt 5:17-20), but probably because he finds the sympathetic portrayal of the 
Jesus insists that $h$ is followers "not resist one who is evil" (5:39). If they are struck on one cheek they are to proffer the other $(5: 39)$. If they are sued for their coats they are to offer their cloaks, and, if forced to go one mile, they are willingly to go two. They are to give to anyone who asks $(5: 40-42)$. At the conclusion of this section Matthew records that Jesus urges the disciples:

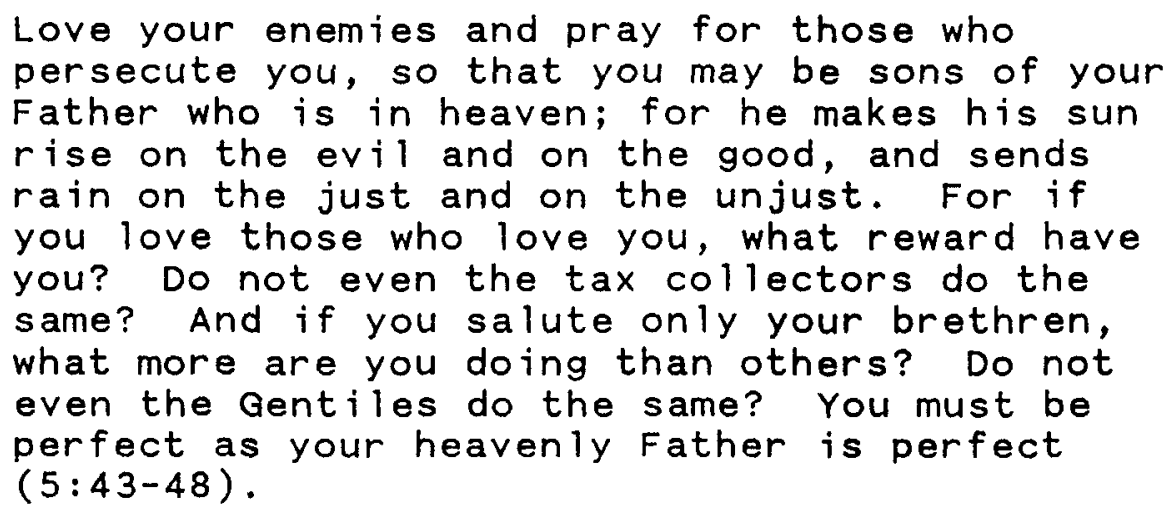

The reward that constitutes the motive for the preceding injunctions is the desire to become sons of God. This reward is not found in earthly acclaim, it is the heavenly approval of the Father.

The command to love one's enemies is central to the Sermon on the Mount and to the synoptic tradition as a whole.62 In Matthew it is especially highlighted and

scribe in Mark at odds with his own portrayal of them. Matthew, too, insists on the priority of the love commandment over ritual demands $(9: 13 ; 12: 7)$.

62 It is true that Mark does not explicitly refer to the command to love one's enemies. John Piper, however, sees a correlation between the call to serve in Mark and the love commanded in Matt 5:43-48: 
Schrage goes so far as to say that "the real standard for correctly interpreting the law is the law of love."63 it is in these verses that we find a central motive for the ethical teachings presented in the sermon on the Mount. Here the ostensible reason to love one's enemies is to become sons of the Father. The religious desire to be like God is, therefore, the motivating force behind the fulfiliment of the ethics presented in Matt 5:21-48. These verses do not suggest that by loving one's enemies the enmity will cease, although some have detected such a "strategic" motive in this passage and its parallel in Luke. For example, in his article, "The Inadequacy of Selflessness," Stephen Post insists that these passages are addressed to believers whose love for outsiders is evangelical. Love seeks to expand "the circle of reciprocity to include new participants.... An attitude of

It is not illegitimate to view the service referred to here [Mark 10:43-45] as a paraphrase of the love which Jesus commands elsewhere (Mt $5: 43-48$ ). Both involve selfrenunciation for the sake of another. Both are promised a reward. Love is related to the love of God (Mt 5:45,48; Lk 6:36); service is related to the mission of Jesus (Mk 10:45) (Love Your Enemies: Jesus' Love Command in the Synoptic Gospels and in the Early Christian Paranesis [Cambridge: Cambridge University Press, 1979] 87).

63 Schrage, Ethics, 148. 
forgiveness is recommended without which the sphere of mutuality cannot enlarge." 64

Luise schottroff comes to a similar understanding of these passages:

- The Christian is challenged to include $h$ is persecutor in his own community, the community of 1 ife together which is awaiting the coming salvation. But of course the Christian's enemies are human beings who reject and refuse this invitation and on their part wish to detach themselves. Consequently, the command to love the enemy is thoroughly aggressive, though not in a destructive sense. The enemies are to abandon their enmity; in other words they must undergo a change of attitude. The command to love the enemy is an appeal to take up a missionary attitude toward one's persecutors. "Overcome evil with good" (Rom $12: 21$ )--that is exactly what it means to love the enemy. The a im is to conquer him.65

For these two scholars love of one's enemies is a missionary or evangelistic tool that promotes the Kingdom. One loves the enemy in the hope of making an ally. While such an interpretation may be valid in light of New Testament ethical injunctions as a whole, the texts in question do not explicitly make such a claim. Furnish interprets the text more accurately when he says that "it is a...distinction of Jesus' love command that such love does not await, anticipate, or require a response in kind." For Furnish enemy-love is not to be conditional upon the response of the

64 JAAR 56 (1988) 223.

65 "Non-Violence and the Love of One's Enemies," in Essays on the Love Commandment (Philadelphia: Fortress, 1978) 23. 
enemy. The believer's love is not explicitly motivated by the desire to overcome the enmity of the other person:

Loving him is not proposed as a means of transforming him or of dissolving the issues which may have generated the enmity in the first place. Though such issues remain standing, they are now approached, from one side at least, in ways directed by love. Thereby the whole relationship between us is changed, although the enemy remain "the enemy."66

66 Furnish, Love Command, 67, emphasis his. Piper disagrees with Furnish's analysis by relating the Lord's prayer (Matt 6:9-13) to the antitheses in Matt 5. For Piper it is inconceivable that prayer for enemies does not include the wish that they come to do God's will and thereby eradicate the enmity. "That a man should pray for his enemy and not request that the enmity between them be removed would be a questionable manifestation of love, to say the least" (Love Your Enemies, 143-44). Also see F.W. Beare, The Gospel According to Matthew (Oxford: Basil Blackwell, 1981) 162. Despite the proposals of Post, Schottroff and Piper, 1 find no indication in the text at hand to suggest that love of enemies is commanded in order to bring more people into the Kingdom. The emphasis is on the disciple's actions and how the disciple should behave. The aim of the text is to bring the disciple into harmony with God's will, rather than the enemy, although the latter may ultimately come to the Kingdom also. Reinhold Niebuhr notes that the text does not claim that enemy-love will transform enmity into friendship and suggests, "That social and prudential possibility has been read into the admonition of Jesus by liberal Christianity" (Reinhold Niebuhr, An Interpretation of Christian Ethics [New York: Meridian Books, 1956] 46). The behaviour required by the command to love one's enemies involves deliberately rejecting the pursuit of justice for oneself, while allowing the enemy the opportunity to willfuliy trample one's rights. Lohfink notes that according to the calls for enemy-love fighting for one's legitimate rights is now forbidden God's people. Rights cannot be imposed through violence. Followers of Jesus "should give to anyone who asks. They should be willing to let

themselves be forced" (Jesus and Community, 55). That the command to love one's enemy is motivated by something other than enlightened self-interest or evangelistic concerns is especially apparent in Luke where 6:31, the Golden Rule, concludes the first section on love of enemies. Harvey says 
Uirich Luz captures the essence of the passage by noting that enemy-love is not advocated "because it is reasonable or natural or promises success but because the one who makes it is as the risen Lord with his community all the days to the close of the age." Questions of whether enemy-love can ever succeed are subordinated, therefore, to the awareness on the part of the believer that it is Jesus who gives the command. Luz notes that "the question is not directly whether it is tactically or psychically realistic but whether the experience of grace which is presupposed in it is so strong that the human being can become free for such a love."67

The failure to take up the challenge to love one's enemies is perhaps the clearest instance of how the church from early in its history up to the present has been especially selective in its response to the teachings in the gospels.68 Nevertheless, we need to recognize that for some

in his comparison of Jesus' positive version with Hillel's negative that "You can never be sure that if you treat people kindly they will show equal kindness in return.... stated quite generally as Jesus states it, the maxim (unlike its negative counterpart) goes beyond the most enlightened common sense" (Strenuous Commands, 107).

67 Matthew 1-7, 351.

68 Uirich Luz believes that by mistaking the love of enemies with some ultimate goal the church has compromised the intention of Jesus (and of Matthew): "Love of enemy was not a chance or a test for the enemy to become something better....Love-with-the-goal-of is not love and not that which Jesus has intended" (Matthew 1-7, 350). 
of the earliest Christian communities, this injunction

formed an important part of their self-understanding and

played a role in the development of their ethic. Harvey,

perhaps, comes closest to explaining why this command is so

captivating while rightly acknowledging that most attempts

to rationalize it somehow fail:

Neither enlightened self-interest, nor

contemplation of God's gracious dealings with

human beings, nor even any consistent trait in

Jesus' own conduct, seems to justify the

utterly unconditional generality of "love your

enemies." And yet the maxim has never been

discarded as perverse, exaggerated or

nonsensical... We perhaps get closest to the

nerve of Jesus' saying when we ponder it as

one of those maxims that gain their power over

us, not because of their enlightened good

sense or religious motivation, but because of

their appeal to a potential that lies deep in

the human spirit, and can occasionally be

activated by the challenge of a totally

unconditional demand.69

The perfection called for in Matt $5: 48$ is moral perfection--

the imitation of God's perfect love.70 This love, which

manifests itself in humble service, is the fitting response

to God's grace and invitation to salvation. The desire to

be like the Father, because one is now his child, is in and

69 Strenuous Commands, 104.

70 Davies and Allison find this call to be part of a paraenetic pattern:

Apparently there is embedded in Mt 5, Eph 5, 1

Pet 1 and 1 Jn 4 a paranetic pattern common to

early Christian teaching: as God's children,

imitate him in his love. Presumably the

pattern derives from the teaching of Jesus

(Matthew 1, 554). 
of itself the primary motivation. The believer does not seek to be perfect in love because he or she wishes to transform the world, but rather because there now exists the desire to conform to God: "Love is not being required because it will set the world right. Instead one's motivation to love arises out of a desire to be like God."71

Allen Verhey interprets all of this passage (Matt $5: 21-48$ ) in light of $5: 20$. The antitheses Jesus lists are to illustrate the "surpassing righteousness" of the Christian community. Matt $5: 20$ is blunt in its insistence that unless one's righteousness exceeds that of the scribes and Pharisees, there is no hope of entering the kingdom of heaven ${ }^{2}$. To enter the kingdom and become sons of the Father are parallel motives which bracket the antitheses.73

71 Davies and Allison, Matthew I, 556.

72 The Great Reversal, 87. I think it is important to note that here (in the sermon on the Mount), as in Matt 23:1-11, the primary purpose of the passage is not to condemn the religious establishment but to lay out a plan of ethical behaviour for those who would follow Jesus. While the Pharisees are portrayed in an unflattering light throughout the synoptic record, the text seeks primarily to promote righteousness amongst Jesus' followers rather than merely to condemn the religious practices of the Jewish authorities. The latter serve more as a foil to highlight the point that the dawn of the basileia necessitates a new understanding (that of Jesus) of what it means to respond to God's will (See also Davies and Allison, Matthew 1, 501).

73 Some, like H.D. Betz, believe that Matt $5: 20$ introduces not only the antitheses but the bulk of the Sermon on the Mount ("Cosmogony and Ethics in the sermon on the Mount," in Essays on the Sermon on the Mount 89-123, [Philadelphia: Fortress, 1985] 92, n.15). Others, such as Christoph Burchard, believe that "5:17-20 must be read as a 
The believer is motivated to attempt to fulfill this ethic not only to fulfill the role as a son of the Father but also because it is Jesus who prescribes it. Those who would obey God hearken to Jesus' words.74 On Matt 5:21-48 Davies and Allison note that while imitation of God $(5: 45,48)$, escaping eschatological retribution $(5: 22-26,28-30)$ and even reason (5:34-36) are given as motives, obedience to Jesus as sovereign Lord is the primary impetus for fulfilling the ethic presented here. One should "faithfully follow the way of the sermon on the mount because the voice in it speaks with divine authority."75

Matt 25:31-46 and its account of the coming of the Son of man illustrates how the motive for service in Matthew can extend beyond imitating God and Jesus, and even radical submission to the authoritative word of Jesus and thereby the will of God. Here righteousness is equated with acts of service toward others which are in fact acts of service toward the king. In his discussion of this passage Furnish says:

preamble to the antitheses and not to the sermon on the Mount as a whole" ("The Theme of the Sermon on the Mount," in Essays on the Love Commandment, [Philadelphia: Fortress, 1978] 68).

74 Schrage points out that Matthew is concerned with "fulfillment of the $l a w$ as expounded authoritatively by Jesus." It is this, rather than the suffering, humility and service of discipleship that is most important for Matthew according to Schrage (Ethics, 145).

75 Matthew $1,565$. 
In Matthew service of the neighbor is not just analogous to the service of God, but it is in itself God's service. The love ethic in Matthew is emphatically christological--not just because Jesus commands love, but because the service love renders the neighbour is service to the Lord Christ. ${ }^{76}$

Thus while the passage can be interpreted as simply a promise of the kingdom to those who feed the hungry, clothe the naked, and $v i s i t$ the sick and incarcerated, and eternal punishment to those who do not, it also provides another motive. The "least" represent the son of man and must be served.

In Matthew we find similar motivations to serve others as we noted in Mark. We find in Matthew more references to reward as a motive. Like Mark, however, Matthew portrays Jesus' ethic as running counter to what the gospel itself presents as the conventional morality of $h$ is day. Those who are "sons of their Father in Heaven," who seek to inherit the kingdom and eternal life, are those who are willing to serve others.

III. Luke

In Luke different emphases can be detected in the discussion of motive concerning the servant-ethic. These differences can be attributed to the special interests of Luke. Like Matthew and Mark, Luke seeks to present the consequences of, and motives for, discipleship and service

${ }^{76}$ Furnish, Love Command, 81, emphasis his. 
in his gospel. Luke, however, offers a different slant on the issues that is especially reflected in his concern with wealth and social prestige.

In the first chapter of Luke we find what Schrage terms "his encouragement of humility and warning against lust for power" in Mary's Magnificat (Luke 1:51-52).77 The opening verses of Luke's gospel reveal his particular concern for the lowly and the humble, and his belief that it is these for whom God has a special concern. Believers are not to seek prestige or power. God does not exalt the arrogant, and the example of Jesus is one of service. This is especially apparent in Luke 22:24-27, in which Jesus tells his disciples that although the one who sits at the table is usually considered the greater, he (Jesus) is among them "as one who serves."

The Lukan account of this episode (a parallel of Mark $10: 42-45$ and Matt 20:25-28) is important because in the third gospel we find the dispute occurring at the Last Supper, following the institution of the Eucharist, rather than at an earlier point in Jesus' ministry.78 This points to a certain similarity to the footwashing episode in the

77 Schrage, Ethics, 156.

78 it seems likely that the reference to the cup in the Markan and Matthean accounts inspired Luke to place this episode at the Last supper. He omits the details of the dispute, including the involvement of James and John and their request to sit next to Jesus "in glory." 
gospel of John in which Jesus washes the disciples' feet and insists that they imitate him during the Last supper.79

Both Luke and John portray Jesus as one who serves during the Last Supper.

The comparison with the Gentile authorities (Luke 22:25-26) also varies from the Marcan and Matthean accounts. One difference is that the word "benefactors" (euergetai) is substituted for "great men" (megaloi) in the two other accounts.80 More important is the Lukan omission of Jesus.

79 see below, chap 2.

80 Gnilka describes Luke as giving Jesus' words a Hellenistic shape or form (Gestalt) here (Markus 11, 100). Also see, David J. Lull, "The Servant-Benefactor as a model of Greatness (Luke 22:24-30)" in NovT 28 (1986) 289-305, for a different approach to the text which understands euergetai in a positive light. Lull's reading of this passage seeks to address the scholarly consensus that "benefactors" in Luke 22:25 are in fact oppressive tyrants. He suggests that the euergetai are rather models the disciples should seek to emulate. In his conclusion Lull says:

Those who aspire to "greatness", but who are not yet called "benefactors" ( $\vee 26 a)$, are advised to follow the example of Jesus, the servant-benefactor par excellence ( $v 27 \mathrm{~b})$, and that of those apostles who remained with Jesus throughout the passion ( $\vee 28)$ (303).

Thus in Luke, according to Lu1\}, those in authority are often not tyrants but ones who exercise their power in service to others. Jesus, of course, is the supreme example of this ideal. Lull's thesis would be persuasive were it not for the fact that the entire synoptic tradition is built upon the paradox that Jesus the Lord behaved as a servant and as such was an example to those who would be present at the messianic banquet or would become part of the kingdom of God. His greatness is not founded upon widespread public recognition. Luke's changes to the text here cannot be attributed to a desire to emphasize the role of so many 
saying in Mark 10:45 about the Son of man serving and giving his life as a ransom for many.81 Instead Luke has a verse in which the verb diakoneo is used in its more literal sense of serving at table, although there is no doubt that such service performed by Jesus is to be exemplary for the disciples.82 As in Matthew and Mark, one of the motives for the servant-ethic is the example of Jesus himself. Another of Luke's primary motives for serving others and putting their interests first is reflected in texts dealing with money and possessions.83 for Luke it is necessary to adopt a certain perspective on wealth if one is to exhibit true discipleship. Coming to believe transforms the believer's attitude towards money and possessions. Indeed, one could say that one thread running through LukeActs is the idea of service by surrendering personal

characters in Luke-Acts (Lull names at least fourteen) as "servant-benefactors" who consider Jesus to be their supreme example.

8 1 see Fitzmyer, Luke X-XXIV, 1413-1414.

B 2 Luke perhaps avoids using the noun diakonos in $\vee .27$ because it had already become a technical term for an office in the christian church. Fitzmyer, however, thinks that the participle diakonon might itself "represent the service of the church in Luke's day" (Luke X-XXIV, 1417).

a 3 We need not go into this particular aspect of LukeActs in any great detail. Many scholars have written much about Luke's attitude towards wealth; e.g., Luke T. Johnson, The Literary Function of Possessions in Luke-Acts. Most commentators and writers on New Testament ethics also include sections on this emphas is of the third evangel ist (e.g., Fitzmyer, Luke 1-1X, 247-251; Schnackenburg, Moral Teaching, 127-131). 
possessions and wealth (e.g., Luke 6:27-36;12:13-21; 19:110; Acts 2:44-45). Luke $6: 27-36$ is parallelled in Matt 5:39-48. In Luke, however, loving one's enemies is also exemplified by lending, "expecting nothing in return." The ostensible motive, to receive a great reward and become "sons of the most High," is similar to Matthew's. Like Matthew, however, Luke seems to assume that true disciples will incline towards such behaviour. Zacchaeus, for example, upon receiving Jesus, immediately sets about making restitution for his past failings. Zacchaeus is a stark example of the transforming power of true discipleship (Luke $19: 1-10)$. As verhey says, how one uses one's money is "a sign and symptom of the arrival of the kingdom." Zacchaeus" actions to give recompense for his fraudulent past illustrates that Zacchaeus has indeed responded to the message of Jesus. "Generosity and alms are not merely illustrative; they participate in the reality to which they point--the reign of God."84 No motive for Zacchaeus' action is explicit here--it seems to be the natural outcome of his reception of Jesus and $h$ is consequent salvation. His willingness to place his possessions at the disposal of the poor (who apparently have no explicit claim upon him), and those he had deliberately defrauded in the past, reflects how his life has been transformed by his encounter with

4 The Great Reversal, 94 , emphasis his. 
Jesus. Zacchaeus has been integrated into the new community--those who respond to Jesus and his mission. His attempts at restoration exemplify $h$ is metanoia. Right use of material possessions occurs when one seeks to serve God by serving others.85

The passage concerning the unfair inheritance (Luke 12:13-21) is also important to establish Lukan motives for the command that one put one's possessions at the disposal of others. In this passage Jesus warns against covetousness by reminding $h$ is listeners that "life does not consist in the abundance of possessions." The motive here, then, for eschewing one's right to part of an inheritance should one's co-inheritor wish to deny it, is a desire to repudiate selfishness. This will naturally occur, the passage implies, amongst those who place their trust in God to provide. The parable of the foolish rich man, which follows this saying (Luke 12:16-21), concludes with the remark that the one who "lays up treasure for himself" is like this foolish example rather than one who is "rich towards God" (Luke 12:21).

85 The parable of the Good Samaritan also exemplifies this aspect of the Lukan ethic (Lk 10:30-35). The passage serves to illustrate the command to love one's neighbour as oneself by explaining who is one's neighbour. Part of the parable, however, tells how the Samaritan assisted the traveller by paying for his keep at the inn. See fitzmyer, who, while admitting that the parable was told for another purpose, notes that it "exemplifies a right use of material possessions to aid an unfortunate human being" (Luke 1-IX, 249). 
This attitude of indifference to material wealth is reflected in Luke's account of how the early community at Jerusalem distributed their possessions to those in need (Acts 2:44-45). Again there is no clear motive for this sacrifice, other than to illustrate the new life in the Christian community which seeks to alleviate the suffering of others $(2: 45)$ by surrendering personal wealth.86

Finally in Luke 17:7-10 we have the clearest instance of the evangelist's belief that service to others is the natural outcome of following Jesus' way. Leaving aside the exegetical and source-critical questions that are inherent in the interpretation of these verses, 87 it is evident that these verses show first that service is the natural outcome of discipleship and second that such service can never be completed--the servant can never anticipate reward or recognition. The believer can make no claim on God and any reward for service is an act of grace.

In Luke's account we have found it more difficult to discern specific motives for serving and placing oneself (and one's possessions) at the disposal of others. While

86 See Luke 16:9 for a saying which probably reflects this sentiment. Schrage, while acknowledging the difficulty of interpreting this verse, concludes: "The crucial point is to use earthly possessions in the service of love... This love...controls and restricts the use of possessions lest they become a source of idolatrous dependence" (Ethics, $106-107$ ).

87For a summary see Fitzmyer Luke $X-X X I V, 1144-1146$. 
reward is mentioned, and there does seem to be an attempt to present a stance that deliberately repudiates ambition and the lust for power, Luke, more than either Matthew or Mark, appears to see serving others as the natural outcome of discipleship. Verhey notes that repentance in Luke is integrally bound up with sympathy to the poor and practicing fairness and generosity towards the outcast.88

IV.Summary of motives for the ethic in the synoptics

The synoptic tradition, as a whole, presents an ethical challenge which, if taken up and discharged, declares the kingdom and identifies its subjects. There are at least four threads that can be unravelled from our discussion above that unite in the motive for the servantethic in the synoptic gospels. It is difficult to separate these interwoven strands but the following remarks are an at tempt.

i) The Desire to Imitate God and Christ

In resolving the squabble of the disciples about who is the greatest Jesus reminds his 1 isteners that the son of man came not to be served but to serve and that he is paradigmatic (Mark 10:45 and par.). Self-denial and the abandonment of one's own interests are enjoined using the example of God who acts towards the evil and the just impartially (Matt 5:45). Believers are to be merciful, even

B $B$ The Great Reversal, 95. 
as God is, to the ungrateful and the selfish (Luke 6:35-36). The call to serve others and abandon the pursuit of personal justice is fulfilled in part, but not completely, by a conscious attempt to emulate some aspect of God or Jesus. There is here a dimension of self-awareness enjoined that provokes the believer to consider how his or her actions correspond to the divine example. This self-awareness arises from the other factors that are part of the synoptic motives to serve.

ii) The Recognition of Jesus as Sovereign Lord such imitation of Jesus and God arises from the recognition that God's authority resides in Jesus. Jesus' pronouncements are authoritative because they are $h$ is and thereby God's. When he enjoins his followers to serve others and to relinquish their rights, even to be prepared to surrender life itself, his admonishments are sanctioned because he speaks as God's representative. Those who respond to Jesus' authority by undergoing metanoia recognize in Jesus' words God's call to repentance and his requirement for subsequent service of others. Serving others is the fulfillment of God's will and arises from the desire to carry it out.

iif)The "Natural" Result of metanoia

True discipleship brings about a change in disposition that makes the interests of others paramount, and that naturally leads to serving others, or at least to 
the inclination to do so.89 Thus, although the promise of reward is often included in exhortations to such behaviour, the synoptic tradition tends to imply that true disciples will be inclined to serve others as a result of their decision to follow Jesus. Such a decision also involves a readjustment of priorities. Those who follow Jesus, who seek to become a part of the basileia of God, must no longer pursue selfish ambition according to established norms.

Their experience of metanoia brings about the realization that true wealth is treasure in Heaven rather than on earth, and that true greatness lies in service rather than social prestige. To serve even a little child as one would serve Jesus, is to honour God and obey his will. it is, as Jeremias says, an expression of gratitude for God's grace that is part of repentance.90 $1 t$ is at this point that the response to the call to serve surpasses calculated strategies to ultimately advance one's own advantage or diminish others', and becomes joyful participation in the kingdom. Metanoia involves a total transformation that not

a 9 windisch, while insisting that the imperatives in Matthew 5 are indeed commands, also recognizes that the spiritual condition of the hearers of the sermon on the Mount must be such that each individual can respond to the challenge that these commands present (The Meaning of the Sermon on the Mount, 88-89). Also see Schnackenburg, Moral Teaching, 114-167 concerning Jesus' motives for $h$ is moral imperatives, and the ideas of reward, imitatio dei, and imitatio christi.

90 New Testament Theology, 217. 
only includes a turning to God. but also a turning away from conventional human norms and standards. Success and failure, wealth and poverty, honour and rejection, are all measured on a far different scale by the one who has experienced repentance in recognition of God's grace. Metanoia gives rise to a "transvaluation of values" that encourages, to use Bultmann's phrase, "the overcoming of self" rather than the pursuit of self-interest. 91 iv) The Hope of Eschatological Reward The response to God's grace as it is manifested in the servant-ethic arises primarily from gratitude and not hope of reward. The promise of reward is never the primary motive for placing one's interests last. Despite this apparent idealism, it must be faced that the synoptic record speaks of reward often and it constitutes part of the motive to serve. I think Jeremias is wrong in suggesting that Matt 25:37-40"is an abolition of the idea of reward."92 perhaps one could suggest that the promise of heavenly reward may motivate an individual to take up his or her cross, but that once that decision is made, the disciple spontaneously places the interests of others first.93 Jeremias is then correct in his insistence that "in the

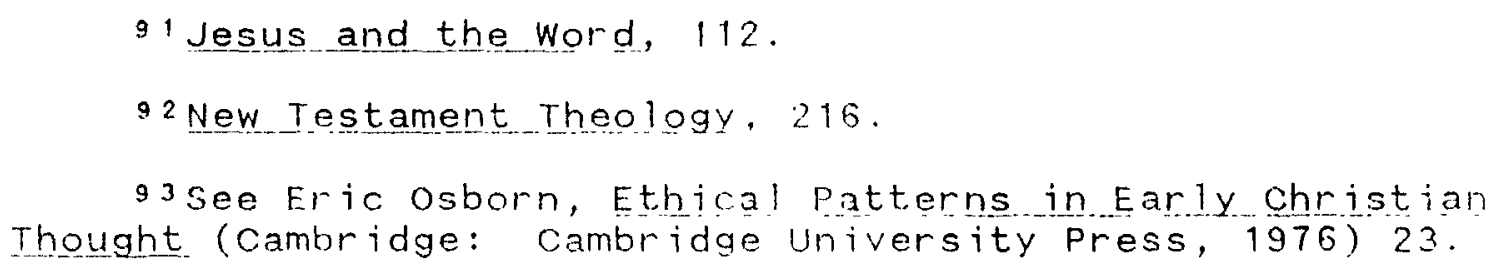
Thought (Cambridge: Cambridge university Press, 1976) 23. 
sphere of his [God's] reign another motive for action takes the place of the idea of merit and the claim to reward: gratitude for God's grace." 94

The response to the synoptic call to serve is motivated, then, by a complex of incentives that depend upon each other and are integrally related. They are grounded in the experience of grace that the early Christians believed was manifested in Jesus, and arise from the selfunderstanding of believers as participants in the basileia. As we have said at the outset, we are not claiming that the earliest audiences of these injunctions to serve actually succeeded in living out their daily lives as servants of others. They probably did not set aside their own interests consistently and rigorously. The synoptic record reveals, however, that the ethical reflection of the writers included a characteristic note of self-denial that was fixed in their convictions about the nature of Jesus and his ministry, and the appropriate response to him. This had to have had some resonance in the earliest audience and therefore must have been manifested, if only sporadically, in their daily

94 New Testament Theology, 217, emphas is his. Jeremias, as well as many other scholars, goes too far in attempting to push the thesis that Judaism emphasized the idea of merit while Jesus' teaching did not. There are many passages in Jewish writings which refute the notion that one fulfills the law to gain "brownie points" in the eyes of God. Likewise, as we have seen, many gospel passages promise reward to those who are obedient. The crucial point in both traditions is to honour God's will, a sentiment which is reflected, for example, in Luke 17:10. 
conduct. All human behaviour is based on some kind of motivation and the synoptic gospels are clear that for believers self-denial is the ideal to be pursued based on their experience of God's grace.

Limitations upon the synoptic call to serve

Having considered the content and motives for the servant-ethic as portrayed in the synoptic gospels, we now need to consider whether there are any limitations upon serving others in these texts; that is, situations in which prudence or justice, for example, might restrict the call to self-denial and the surrender of one's own rights.

The key to the servant-ethic in the synoptic gospels is the response to God's invitation to the Kingdom. Once an individual has repented he or she becomes open to the will of God. Selflessness and a complete willingness to serve others becomes the moral guide-post. Any act in which the interests of the self are placed before the interests of others constitutes a violation of God's will. As L. H. Marshall has said,

When a man repents he stops thinking of and caring for himself alone; and takes God and $h$ is neighbour into all his thoughts and into all his decisions in matters of conduct. The rule of self is abandoned for the voluntary acceptance of the rule of God.95

95 The challenge, 35. 
Thus it is possible to envisage situations in which an individual serves others by resisting evil, though Jesus nowhere makes this explicit. For the resistance to be Christian, according to the synoptic teaching, it must not be done out of revenge or for personal benefit. Christians have long wrestled with this very question, and today many struggle to find the appropriate response to such endemic problems as totalitarianism and racism.96

Reinhold Niebuhr points out that the prosecution of justice can often be undertaken selectively for personal benefit:

From the first restraints upon blood vengeance to the last refinements of corrective justice, the egoistic element of vindictiveness remains both an inevitable and a dangerous alloy in the passion for justice. It is inevitable because men never judge injustice so severely as it ought to be judged until their life, or life in their intimate circle, is destroyed by it. 97

Throughout history Christians have argued over the appropriate actions in the face of evil, and even over the definition of what constitutes evil.98 Some Christians

96 See Joseph L. Allen, Love and Conflict, 198-217, for examples of such resistance. Many contemporary Christians strive to overcome racism and totalitarianism at great personal cost in order to serve other human beings.

97 An Interpretation of Christian Ethics, 49-50.

98 One does not have to look as far back in history as the great church councils and their struggles to define orthodoxy, or even the age of the Reformation, to see examples of how unclear the christian position on evil can be. It took the occasion of Vatican 11 for the Roman 
believe that there are cases when war is justified to thwart tyranny and to serve the interests of innocent victims.

Others believe that participation in armed conflict is

Catholic church to officially declare anti-semitism a sin. In the early months of 1991, many christian groups struggled with the theory of a just war and whether it applied in the coalition assault against the Iraqi occupation of Kuwait. Some of their doubts sprang from the suspicion that if it justified this case it justified so many others as to render the very theory impractical. It is possible to cite examples that are even more recent: in the opening weeks of 1992, the Dutch Reformed Church suffered a schism in South Africa because of its official opposition to apartheid, and following the disintegration of the soviet Union questions have arisen as to the complicity of the leaders of the Russian Orthodox church in matters of oppression and despotism. Jesus does not deal with such questions in his teachings as recorded in the Gospels. This is not only because such dilemmas are anachronistic, although undoubtedly he and the gospel writers were aware of atrocities and persecution that were a result of the Roman administration of palestine, but because they are not the stuff of everyday ethical struggles. Jesus' teaching does not call for institutional morality or "official" ethical positions--it reflects the values of the basileia. The gospel teaching tends to concentrate on the everyday, on the personal. The synoptic Jesus does not tell his 1 isteners how they, as a group, should react to the oppression of living in an occupied land; he tells them how to respond to personal rebuff, to particular but often extreme situations, with the implication that the broader questions of political and social injustice depend upon the believer's self-conscious awareness of her or his role as a child of God and servant of others. Consequently, Jesus. teachings may well have relevance to the situations noted above, and it is certainly appropriate for modern christians to seek the resolution of such dilemmas, or at least the key to their resolution, in the gospel texts. They should be aware, however, that the sum of the synoptic gospel-message must be taken into account and not simply such texts as Matt $5: 43$ or conversely 10:34. For an example of a modern attempt to find such a resolution to contemporary problems of war and peace using biblical resources see William Klassen, Love of Enemies: The Way to Peace (Philadelphia: Fortress, 1984). 
always forbidden.99 it is not unreasonable to suppose that such dilemmas also confronted the earliest communities of believers, especially since we have the historical records of divisions within Judaism over such questions. It is always useful to remind oneself that in its genesis Christianity was a Jewish sectarian movement amongst many. and that most of the social and political questions that confronted Jews in first-century Palestine and the Diaspora must also have challenged their christian contemporaries.

9 9Reinhold Niebuhr warns against attempts to translate too directly Jesus' ethics into social or political policy because it "usually has the effect of blunting the very penetration of his moral insights." Niebuhr insists that the call for non-resistance cannot simply be translated into an injunction against violence because "it ceases to provide a perspective from which the sinful element in all resistance, conflict, and coercion may be discovered." Niebuhr suggests that those who are most vocal in advocating non-retaliation are often those with the "economic power to be able to dispense with the more violent forms of coercion and therefore condemn them as un-christian" (An Interpretation of Christian Ethics, 52). Contemporary Christian pacifism that is based on an interpretation of synoptic and biblical principles, however, has manifested itself in social and political activism that has had profound consequences. The civil-rights movement in the United states during the $1960^{\prime} \mathrm{s}$ (subsequent to the publication of $\mathrm{Niebuhr's} \mathrm{book)} \mathrm{is} \mathrm{a} \mathrm{startling} \mathrm{example} \mathrm{of} \mathrm{how}$ a group with limited economic power managed, on the whole, to "dispense with the more violent forms of coercion." of course, the principles of individual rights inherent in classical liberalism were already in place in America, but only the most cynical would deny that during those years of struggle the west witnessed a profound social and political transformation that was inspired by the belief that oppression should not be overcome with violence. That this movement gained its initial momentum in the black churches of the American south testifies, in this instance at least, that the inspiration to seek social transformation can be found in the gospel. 
A general observation can be made, however. For both the earliest and modern readers of the synoptic record there is the sense that no one can claim to be promoting God's will if her or his actions spring from selfish interests. Selflessness, not selfishness, is to guide the moral decision-making of a christian. To do the will of God is to be the primary incentive of all christian action and, as we have seen, this is the over-riding motive for the synoptic call to serve. Obedience is required not only to Jesus' words but also to his example.

The general impression that there are no limitations upon the synoptic call to serve, which becomes most overt upon reading the extreme examples in Matt 5:34-42, has led many scholars to identify the ethic itself as a limitation or liability: in their view it is impossible to fulfill it.100 As far as 1 can tell, when the synoptic tradition is

100 See Joseph Klausner, Jesus of Nazareth [New York: Menorah Publishing, 1925] 392-397, and Montefiore, synoptic Gospels $11,86-91$ for a critique of synoptic ethics using this exact point. Also see knox, 18-23 for an apology of the ethic which also accepts that it is impossible to fulfill. C.H. Dodd in his discussion of this point reflects upon the "unlimited scope of God's demands." They lead to an acute realization in the hearer of the need for repentance (Gospel and Law, 60-63). Windisch, however, contra Montefiore, Klausner, knox et al, defends the position that the antitheses are not only commands but are also practicable. He quotes slavonic Enoch $50: 3-4$ which encourages one to endure $i 11$-treatment, not to retaliate, and to wait upon the Lord to avenge on the day of Judgment, as an example of a similar ethic in Judaism. Also see Windisch, 95-123, and his conclusion that the individual sayings of the sermon on the Mount are to be understood and interpreted literally. Thomas Ogletree calls for a middle 
read as a whole, there is no $1 \mathrm{imit}$ to the injustice a

follower of Jesus must be prepared to suffer at the hands of

another, or to the lengths that a believer must go to

serve.101 The language used speaks of giving one's life or

path that takes into account the eschatological emphasis of Matthew. Ogletree believes that the delay of the eschatological fulfillment means that "it is necessary to delineate a legitimate self-defense and to set appropriate limits to the claims which others may be permitted to make" (The Use of the Bible in Christian Ethics [Oxford: Basil B lackwe11, 1983] 108). For Ogletree, however, the eschatology of Matthew's gospel does not render his ethics invalid since they offer a "realistic assessment of what is entailed if we are to break the structures of destruction which presently order human life" (ibid., 109). Indeed the critiques of human ambition and pursuit of self-interest that pervade the synoptic record and the subsequent call to seek alternate paths, however idealistic, or even unrealistic, are certainly applicable to contemporary social structures and political ambitions. Finally, Davies and $A 11$ ison insist that Matt $5: 21-48$ is not a moral code but a stimulus to the "moral imagination." It does not offer "irrevocable statutes or bloodless abstractions" but rather "an unjaded impression of what is right and wrong, a challenging moral ideal" (Matthew I 566). The challenge can only be taken up by those who respond to the central call for repentance in the synoptic texts. Those who reject the necessity for metanoia before God must, and indeed do, seek alternate ways to overcome the human failings that manifest themselves in petty squabbles and bloody wars. For the earliest believers who produced and read the synoptic texts, the idea (or ideal) of self-denial and service to others resonated as an invitation to make known the will and love of God.

101 According to the synoptic texts, however, even Jesus, despite $h$ is crucifixion, does not deliberately seek opportunities to suffer injustice. In Matt 12:15-16 Jesus' command that he not be made known is not part of the "messianic secret" as it is in Mark, but is rather an attempt to avoid the persecution of the Pharisees who seek to destroy him $(12: 14)$. Immediately following this Matthew inserts the quotation from is $42: 1-4$ that speaks of the servant who proclaims justice to the Gentiles. William Klassen speaks of how this passage in Matthew illustrates that "by the way Jesus receives injustice, he becomes a king 
of losing it, and of surrendering one's material

possessions. Questions of justice in the sense of

protecting one's own rights are set aside.102 Prudence, in

who brings justice to others" and that "By retreating from the conflict and refusing to assert his own rights or engaging in public demonstrations or affirming his essential benevolence, Jesus leads justice on to victory" (Love of Enemies, 77). It is God's justice that Jesus proclaims, which always involves divine grace, and not human approximations that involve rights and claims and privileges. In this case, in Matthew, Jesus avoids $h$ is opponents' attacks but the writer is careful to note that in doing so he fulfills his role as God's servant. It would be perverse to equate the synoptic call for self-denial with deliberate attempts to seek after mistreatment and. persecution.

102 In his commentary on Mt 5:38-42, Francis Wright Beare notes that this passage perhaps invites a second blow and that it is preferable to endure further attacks than to fight back. As we too have noted above Beare points out that there is no special motive for such non-retaliation. Questions of justice and personal rights do not enter the picture:

It is presupposed that the attack is unprovoked and unjustified, and that the man attacked might have the right to defend himself; he is not to stand on his rights, but to act as befits a disciple of Jesus, a member of the kingdom of heaven, who will not be moved to hostility by any wrong done to his person (Matthew, 158).

Goppelt notes that Mark 10:42-45 par. illustrates this principle: "Jesus did not bring this reign through the establishment of rights by litigation in a court of justice nor through a demonstration of might by toppling the powerful, but through servanthood" (Theology of the New Iestament । [Grand Rapids: Eerdmans, 1982] 114). 
the sense of protecting one's future interests is waived in favour of fulfilling God's will in the present.103

We should, however, infer from the gospel texts that one's fulfillment of the call to serve others must not impede the honour due to God. The first part of the love commandment requires love of God and many texts which describe the conditions of discipleship insist that the demands of human relationships be subordinated to those of God (e.g. Matt 10:34-39; Luke 14:26). God and $h$ is kingdom have unrivaled claim upon each disciple and the believer's obedience to him must not be compromised in serving others. Love is to be mirrored in every action and in all human relations. Thus, although the community of Jesus stands counter to society, it does not take up an adversarial stance towards social norms and requirements. Rather, its members voluntarily surrender their rights in order to reflect the authenticity of the new order god is establishing.104 Questions of conventional prudence,

103 There is perhaps one exception to this. In Matt 5:25-26 (par Luke 12:57-59) Jesus' hearers are advised to "settle out of court" with their accusers in order to avoid going to prison. Fitzmyer describes this as "Jesus challenging $h$ is audience to timely and prudent reconciliation with one's opponent" (Luke X-XXIV, 1001).

104 Sometimes, as Jesus' own example makes clear, situations arise in which acts of service may violate the wishes of others but ultimately attend to their interests. The sharp denunciation of $h$ is opponents is an example of how Jesus sought to "serve" his critics by severely insisting on their shortcomings in fulfilling God's will. Some commentators see Jesus' practice in these situations as 
being at odds with the ethic he preached. Joseph Klausner for example discerns a vast gulf between Jesus' preaching and practice of his own ethics. He points to Jesus' habit of addressing the Pharisees with such epithets as "hypocrites" and "serpents" and his violence against the money-changers in the Temple (Jesus of Nazareth, 394-95). Davies and Allison confront this critique with five possibilities:

i) Jesus is exempt from the commandment to love: he is rather the judge.

ii)By their rejection of Jesus, the scribes and

Phar isees have become enemies of God and the command of enemy-love applies only to personal enemies.

iii) The contradiction cannot be overcome.

iv) The rebukes are required in order to correct error but are motivated by love.

v) Ideas and abuses rather than individuals are attacked, so the reprimands are general and are not directed at specific persons.

Like the evangelist, Davies and Allison draw no conclusions on this matter (Matthew 1, 563-64). The least satisfactory seem to be $i$ and $i i$. In the case of $i j i$ it is only to be accepted if one insists that there is indeed a contradiction between Jesus' preaching and practice. In the context of the dawn of the basileia, or more generally, of experiencing the grace of God, iv appears to be most acceptable. Love of others often involves attempts to correct error in the hope of averting future harm to the beloved. Jesus' table-fellowship with Pharisees and his approving words to individual members of the religious establishment reveal that $v$ is also to be given consideration.

More troubling perhaps is the single instance in which Jesus' followers are told to rebuke non-believers. In Luke 10:11 Jesus tells $h$ is disciples who are about to embark on missionary activity that if any town does not receive them they are to say:

Even the dust of your town that clings to our feet, we wipe off against you; nevertheless know this, that the kingdom of God has come near.

In the parallel texts of Mark 6:11; Matt 10:14 and Luke $9: 5$ the rebuke is not spoken but is simply symbolized in the act of shaking the dust from their feet (See also, Acts 13:50). Mark makes explicit to his readers that this is a testimony against those who will not hear their message but Matthew is 
propriety and common sense become secondary in light of the kingdom. Compromise, as the rich young man discovered, is out of the question. God demands full allegiance, which is achieved, in part at least, by relinquishing one's human ambitions in favour of serving others.

Nevertheless, the ethic of service as presented in the synoptic tradition does seem to permit resistance to evil on behalf of others. This can only be inferred since there is no definitive text. The idea that a follower of Jesus would stand by and witness the abuse of an individual and thereby claim that this was to fulfill Jesus' admonishment not to resist evil seems ludicrous. On a personal level, the synoptic Jesus encourages $h$ is followers to forego retaliation for injustice suffered, but he is always quick to champion the cause of the oppressed, in the sense that he deliberately seeks out the poor and the marginalized as recipients of a special invitation to the Kingdom. The neighbour is not loved if the christian, when possible, does not prevent him or her from being harmed

silent on this point. Luke 10:11 is the only instance in which the condemnation is to be expressed verbally rather than symbolically. Davies and Allison note that here Luke is making explicit what is implicit in the act of shaking off the dust (Matthew $11,177-78$ ). It is more difficult to account for this allowance for public condemnation on the part of the disciples. Seen in light of the serious implications of dismissing the disciples' message (which is in fact the proclamation of Jesus), the condemnation serves to highlight the danger of such a rejection and can be understood in the same light as Jesus' condemnation of his opponents above. 
whenever possible. The aim of the servant-ethic in the synoptic gospels is not simply self-denial but also otherdirectedness.

Conclusions Concerning the Ethic in the synoptic Gospels

As we noted at the beginning of this chapter, Montefiore understands the call to serve as part of a "grand paradox": it is the path, according to the synoptic writers, to true greatness. The paradox is even greater, however, than the biblical promise of exaltation for the humble and the lowly, when the mot if becomes incorporated into the early Christian theological complex. Jesus is not only son of Man and son of God, according to the synoptic writers, but the servant who gave his life as a ransom for many (Mark 10:45, par.). For many interpreters it is the latter part of this saying that is most interesting because of the problems of historicity. As P.H. Boulton notes, however, greater attention needs to be paid to the first part of the verse and the motif of service.105

it seems clear that for the synoptic tradition, at least, the call to serve is an intrinsic part of new life in the kingdom, and protects against the dangers of human

105 P.H. Boulton, "Diakoneo and its cognates in the Four Gospels," in SE 1, Berlin: 1959, 415. For an argument for the historicity of the entire verse see Peter stuhlmacher, Reconciliation, Law and Righteousness (Philadelphia:

Fortress, 1986) 22 . 
ambition and hubris. Following Jesus leaves no room for arrogance or condescension toward others. It is the way of sacrifice and self-denial that is epitomized in the crucifixion of Jesus himself. The death and resurrection of Jesus is the grandest paradox of all and it is this that provides the paradigm for the synoptic ethic of putting the interests of others first. As Jesus came "not to be served but to serve," so his disciples are called to a similar self-understanding.

In the synoptic tradition we find the call to serve others, and to place one's own interests last, reflected primarily in an attitude of indifference toward seeking justice for oneself, toward material possessions and toward social prestige. The appropriate response to this call is manifested rather by fulfilling the double commandment of love of God and love of neighbour. Furnish says, "One's response to God--setting aside self-will, renouncing one's own claims--is to be paradigmatic for one's relation to his neighbour."106 The synoptic writers present us with a Jesus who called his listeners into a new relationship not only with God but with other people; a relationship that eschewed social convention as meaningless and which inverted usual ways of thinking about personal worth. Mark 10:45 presents Jesus himself as the model for meeting this challenge. A

\footnotetext{
106 Furnish, Love Command, 63.
} 
positive response to Jesus' call and his invitation to take up one's cross--in other words, a willingness to surrender life itself--is the impetus that leads to an existence of service and self-denial. True service can only be carried out, according to the synoptic tradition, if some inner transformation (metanoia) has occurred. This manifests itself as a willingness to sacrifice everything and to place one's own interests last in obedience to the will of God and out of gratitude for the experience of his grace.107

107 As a final note it is interesting to recall the response of Peter's mother-in-law following her healing (Mark 1:29-31; Matt 8:14-15; Luke 4:38-39). The point of the account is first to show that her recovery was so complete that she was able to serve Jesus (Matthew) or Jesus and his disciples (Mark, Luke) immediately, presumably by providing food and other essentials of hospitality. The verb diakoneo also has broader connotations, however. Upon experiencing the benefits of Jesus ministry the woman stands able to serve others. She parallels the jailer who responds to the message of paul and silas (see below, chap 4). 


\section{THE SERVANT-ETHIC IN THE JOHANNINE WRITINGS}

James Gustafson suggests that the obligation to seek the good of one's neighbour is characteristic of Christian ethics.1 It is, however, perhaps not as apparent in the Johannine literature as it is in the synoptic gospels or Paul. Nevertheless, traces of this requirement are to be found in passages such as 1 John 3:16-18, and perhaps Rev 2:19. These texts suggest that the members of the Johannine community also knew the requirements to serve others and to put the interests of others first. The most important indication of this tradition amongst Johannine Christians is the footwashing episode of John 13:1-20. By examining this passage and its relationship to the rest of the Johannine literature, we discover that John confirms the synoptic tradition in terms of the principle of self-denial and the requirement to serve others.

The gospel of John presents a picture of Jesus that, in many respects, is distinct from that found in the synoptic gospels.2 There are, however, points of contact. ${ }^{3}$

1 Can Ethics Be Christian? (Chicago: University of Chicago Press, 1975) 164-65.

2 Barrett offers a short summary of the differences in christology between the synoptics and the Fourth Gospel in $h$ is The Gospel According to John (Philadelphia: Westminster 
In terms of Jesus teaching the footwashing seems to reflect the same $k$ inds of ethical concerns about serving others that we find in the first three gospels. In John this one striking episode serves to highlight an insistence upon loving, mutual service amongst Jesus' followers. At the same time there is a disturbing element in the selfabnegating actions of Jesus. His act of stooping to wash his disciples' feet makes him seem no better than a slave. Peter's horrified response to Jesus' behaviour emphasizes this aspect of the passage. Although the Johannine literature as a whole is important, the footwashing episode is the most significant passage for our purposes.

The problems of interpreting John 13 are extensive, especially if one seeks to uncover the traditions that lie

1978) $70-75$.

${ }^{3}$ Leon Morris, in The Gospel According to John (London: Marshal1, Morgan and scott, 1971), discusses the parallels between John and the synoptic gospels in relation to Barrett's suggestion that certain passages hint at some $k$ ind of literary relationship between Mark and John. Morris, like Dodd (see below), doubts that any kind of literary dependence explains these similarities and opts for common knowledge of similar oral traditions (49-52). The most thorough discussion of this question is found in C.H. Dodd, Historical Tradition (Cambridge: Cambridge University Press, 1965, especially 335-365). Dodd suspects that no direct literary dependence obtains between the fourth and synoptic gospels but discovers evidence for a core of tradition common to all. Unlike these scholars, we do not seek evidence of literary dependence in parallels of events, or even of words, but rather we wish to demonstrate an intrinsic early christian self-understanding by pointing to instances in which the gospel and epistles of John confirm the routine requirements of serving others that are scattered throughout the synoptic tradition. 
behind the passage. Scholars have reached a consensus on few aspects of the text, although most seem to agree that the footwashing episode as it now stands is the result of a combination of two different traditions. Because we will focus upon how this passage reflects the self-understanding of the early Christians, such concerns are not so relevant for our study. Nevertheless, at some points brief allusions to theories concerning the traditions behind the text will be necessary.

We begin by considering the motives for Jesus' action which he directs his disciples to emulate in the future.4 We will then consider how the early Christians might have understood this imperative: how they are to serve as Jesus served. We shall consider whether the direction is to be understood literally or only figuratively, and will briefly examine other texts that describe footwashing. Third, we will consider the text's claim about the resulting benefits of imitating Jesus" behaviour. Fourth, we need to consider the footwashing in the context of Johannine ethics as a whole. We also shall seek any limitations placed upon the requirement to serve others in the Johannine literature. Finally we shall consider the relationship between the

\footnotetext{
4 In this chapter our method shifts from the sequence of considering the content and then the motive for the ethic to the reverse order. This is based on pragmatic considerations and should not disrupt the pattern of the overall investigation.
} 
Johannine literature and the synoptic gospels as it turns upon the principle of placing the interests of others before one's own.

The Motives for Footwashing and Service to others

In a sense there are two motivations for submissive action on behalf of others. The first is the impetus for Jesus' act and the second is the motivation for $h$ is followers. Because we are primarily concerned with the mutual service of the early Christians in this passage it is most important for us to examine the motivation for Jesus' disciples. Nevertheless, we shall first tackle the more complicated question of the motive for Jesus' action because this too will reflect the concerns of the writer.

$$
\text { M-E. Boismard understands } 13: 3 \text { as the key to the }
$$

former. He says:

$$
\begin{aligned}
& \text { Le v.3 non seulement sert d'introduction à la } \\
& \text { scène du lavement des pieds, mais en donne la } \\
& \text { raison d'être essentielle. Le eidos en effet, } \\
& \text { placé en tête de ce verset, a valeur } \\
& \text { causale... i. c'est parce que Jesus sait..., } \\
& \text { qu'il se lève du repas pour procéder au } \\
& \text { lavement des pieds de ses disciples.5 }
\end{aligned}
$$

Boismard believes that the object of Jesus' knowledge is that he has received from God the power to give eternal life. In addition, according to Boismard, this is bound up with an awareness of his mission: "he had come from God and

5M. -E. Boismard, "Le Lavement des Pieds," (RB 71 (1964) 6-7, emphas is his. 
was going to God." Boismard says that "Jesus se met à laver les pieds de ses disciples parce qu'il sait qu'il à bté envoyé par Dieu pour donner la vie aux hommes." He continues by saying, "I existe donc un lien intime entre le lavement des pieds et le don de la vie."6 Apparently, Jesus did not wash his disciples' feet until this point in his life immediately prior to his death. The footwashing somehow concludes his earthly ministry and initiates his departure. Lindars interprets $v .3$ by pointing to the heightened drama and paradoxical nature of the following verses. He sees this verse as introducing the "turningpoint in the grand movement of redemption.... Jesus had come from God... and now was going to God."

Vv 14-15, however, explicitly state that Jesus behaved as a lowly doulos to give his disciples an example.

6 "Le Lavement," 8.

7 B. Lindars, The Gospel of John (London: 01 iphants, 1972) 448 , emphasis his. Also see Barrett, John, 439. The historical-critical problem with v. 3, of course, is that this motive for Jesus act is clearly from the hand of a redactor. In the verses which most scholars agree constitute the "kernel" of this episode (i.e., vv4 and 5) no motive is mentioned. Some, including Brown in The Gospel According to John $X|\|-X X|$ (New York: Doubleday, 1970) would disagree with those who also include, for example, vv12-15 as part of the "kernel," while others would include still more verses. Total consensus can only be reached by assuming that the entire episode apart from $v v 4$ and 5 is in some way secondary. We, however, are less concerned with the history of, and the traditions lying behind, the passage than we are with its significance for the Johannine community and their self-understanding. 
Here, then, we see the second impetus for Jesus' act. In vv14-15 Jesus says:

If 1 then, your Lord and Teacher, have washed your feet, you also ought to wash one another's feet. For I have given you an example, that you also should do as I have done to you.

Just as Jesus has served $h$ is followers they are now compelled to serve each other. It is here that we must attempt to come to terms with the two interpretations of Jesus' act that are given in the Fourth Gospel. Scholarship has determined that $v \vee 6-10$ and 12-20 reflect two different ways of perceiving Jesus' behaviour in vv4-5. The most obvious interpretation is that Jesus washed the feet of his disciples to set an example of humble service that Christians should emulate. Bernard, in his commentary, says that "the simplest explanation is that provided in $\vee v 13-16, " 8$ and rejects the notion that the passage contains any connotation of spiritual atonement or baptismal symbolism. 9

Brown responds to Bernard and others by reminding $h$ is readers that John "has several instances of two-fold symbolism." He believes that those who opt merely for the

Bernard, The Gospel According to st. John 11 (Edinburgh: T. and T. Clark, 1928) 464.

gohn, 463-64. He also insists that the act reflects the dignity of service, an inference that is not necessarily justified. 
"moralizing" interpretation, as Boismard calls it, neglect

the importance of $v \vee 8$ and 10 . He says:

\begin{abstract}
Verses 6-10 indicate that what Jesus has done in the foot-washing is essential if the disciples are to gain a heritage with him (vs.8) and apparently this action cleanses them of $\sin (10)$. Something more than an example of humility seems to be involved. Moreover there is a lack of harmony in the narrative: vs 7 states that understanding will only come afterwards, i.e., seemingly, after the resurrection.... but $v v 12$ and 17 imply that understanding is possible now, as it should have been if only an example of humility were involved.
\end{abstract}

Brown concludes this part of his discussion by saying, contra Boismard, that $\vee v 6-10$ are an earlier interpretation than $v \vee 12-17.10$ This is because, while Boismard interprets vv6-10 sacramentally, Brown understands them as prophetic: they symbolize Jesus" humiliation in death. "The footwashing is an action of service for others, symbolic of the service he will render in laying down his life for others."1

10 Brown, John $x|||-x|, 562$.

11 Brown John $x|||-x| x \mid, 562$. Brown sees the use of tithēnai in $v .4$ as indicating the laying down of 1 ife (cf. $10: 11,15,17,18)$. This understanding is confirmed by $v .7 \mathrm{~b}$. Barrett (John, 439) agrees. Herold Weiss is more interested in locating the significance of the footwashing within the Johannine community. He says that footwashing was practiced in the persecuted Johannine community and that it represented preparation for martyrdom ("Footwashing in the Johannine Community," 300). Weiss also says that John 13 and 1 Pet 2:22 are the only two passages in the New Testament which offer an "Example Christology." (323). Both communities apparently faced persecution and martyrdom and in both passages the example of Jesus is recalled as he faced his suffering and death. Brown, however, also points 
Brown agrees with Boismard, however, that the entire passage reflects the combination of two separate interpretations of the footwashing. He notes, nevertheless, that while vv6-10 can only refer to vv4-5, vv12-20 are more general and could fit with other episodes in Jesus' career. For Brown, vv12-20 are derived from "a collection of miscellaneous material."12

In evaluating the two interpretive traditions within the text, scholars differ as to whether the two are compatible. Buitmann sees a way in which the two interpretations can be understood as congruous. He says:

[The] two interpretations of the footwashing have been combined. The significance of this combination becomes clear when one realizes that both sections deal with the community created by Jesus' service, expounding it as the fellowship of the disciples with him and amongst themselves. The explicit theme of the first section is the fellowship with Jesus; this is shown to be grounded in an event that contradicts the natural reason, namely in the service rendered by Jesus, the binding power of which will prove itself in the historical existence of the disciple, if he is prepared to base his life on this event and on it alone. The second section adds that this fellowship of the disciples with Jesus at the same time opens up a fellowship amongst themselves, and that for the former to exist,

to Heb 13:12-13; II Cor 5:15; Phil 2:5-11; I Tim 6:12-13 as well as I John 3:16 as passages which encourage Christians to recall the example of Christ and to be prepared to imitate him (The Epistles of John [New York: Doubleday, 1982] 449).

12 Brown, John $x|11-x x|, 561$. 
the latter must be made a reality through the disciples' action.13

Whatever the order of priority of the two

interpretations, the passage, as it now stands, relates that the disciples are to be humble as Jesus was. This is the

force of the word hypodeigma in $v 15$. While the dialogue with Peter is an important aspect of the passage and can be interpreted in several ways, on the whole it is more significant in comprehending the Johannine view of Jesus' self-understanding and his relationship to his followers than their own service to each other. For the latter vvi416 are more important. Here it as if Jesus addresses the members of the Johannine church. He instructs them to behave as he has. Emulating his example becomes the motive

13 Bultmann The Gospel of John (Philadelphia: Westminster, 1971) 478-79. Similarly Marianne Meye Thompson insists:

It is doubtful whether...a sharp disjuncture within the text can actually be substantiated. First, there are not really two "interpretations" of the footwashing, but only the one offered in $v v .12-17$. Before that we have the evangelist's editorial comments $(13: 1-4)$ and the event itself, with the accompanying dialogue between Jesus and Peter ( $v v .5-10$ ), but whether either of these constitutes an "interpretation" of that event seems doubtful. Instead, we have an act which, in its wider context, prefigures Jesus' death; and this act taken together with the following interpretation ( $v v .12-17)$, must be read as a unit to discern adequately the meaning of this whole scene within the Fourth Gospe1 (The Humanity of Jesus [Philadelphia: Fortress, 1988] 101). 
for their own acts of self-denying and loving service.14 We should now turn to consider the requirements of that service.

\section{The Requirements of Serving as Jesus Served}

That the footwashing serves as an example to Jesus' followers is generally agreed upon. The requirements of how the disciples are to emulate that example are not, however. It cannot be over-emphasized that Jesus' act was one of complete humiliation and self-abnegation. Bernard, however, resists this by saying that it only seemed to be a great act of self-condescension to the disciples.15 In his interpretation of $v .13$ he says, "Christ affirms his own dignity, even while stooping to what the disciples counted a menial office. He will not permit them to be in any doubt about this."16 Bernard, then, weakens the thrust of $v \vee 4-5$

14 In his article, "John 13:1-20, The Footwashing in the Johannine Tradition," F.F. Segovia makes the point that "the emphasis of this second explanation [i.e. vv12-17 as opposed to $v \vee 6-10]$ is on the ecclesiological implications of Jesus' act (ZNW 73 (1982) 46)." (In n.40, which accompanies this statement, Segovia suggests that "the failure to grasp the primary ecclesiological concerns of the washing in $v V$. 12-17 is, in my opinion, the fundamental weakness of those who interpret these verses primarily in terms of vv.6-10a.")

15 John, 459.

16 lbid., 465. Barrett also cautions against exaggerating "the degrading character of the task" by pointing out that although Jewish slaves were not required to' wash their masters" feet, "wives washed the feet of their husbands, and children of their parents" (John, 440). He cites Mekhilta Exod. 21.2. B. Kötting in his article on 
by insisting that the act is only self-deprecating in the eyes of the disciples. One could argue, on the contrary, that Jesus' act was as lowly and as menial as possible. There were many ways the writer of John could have illustrated the point made in $v v 14-17$, without having Jesus stoop to such an act. Not only does Jesus wash the disciples' feet but he disrobes, and wipes their feet with a towel he has put on. 17 The text re-affirms the paradoxical nature of the servant-ethic, especially when Jesus himself becomes paradigmatic for its content. As we saw in our examination of the ethic in the synoptic gospels the son of Man comes not to be served but to serve (Mark 10:45 par.) and this is starkly illustrated in John 13. Some scholars believe, however, that the nature of Jesus' act cal's into question the entire tradition upon which this passage is based. They have been reluctant to acknowledge the tradition as authentic, often because of

footwashing claims that in the Jewish tradition a wife should wash her husband's feet not as a slave but out of love for him ("Füsswaschung" RAC viii [stuttgart: Hiersemann, 1950] 743-59). (Interestingly footwashing is omitted from the 1 ist of duties a wife should perform for her husband found in m.Ket. 5.5.) Hultgren offers many examples of footwashing in antiquity including sifre Deut. 355, in which a maid-servant washes her master's feet ("Footwashing as a Symbol of Eschatological Hospitality," [NTS 28 (1982) 545, nn13-16]).

17 Bultmann understands these details of $v v 4-5$ as a means to have the reader recognize the absurdity of the event ( John, 466). 
the degrading role it gives to Jesus.18 Many suggest that

the Fourth gospel incorporates in the footwashing account

parts of the gospel of Luke, Luke's Passion account or at

least some of the traditions used by Luke.19 A final

18 This is based in part perhaps upon typical

evaluations of Johannine christology. Many see John as promoting a "christology of glory (doxa)" which emphasizes that John portrays Jesus as radiating the glory of God even while insisting that Jesus is the word made flesh. Lindars points out that while John wanted to guard against docetism amongst $h$ is readers, many passages in fact encourage it (John, 54, 61-63). Schrage also notes this when he iterates Käsemann's point that the emphasis should be placed upon $1: 14 b$ "We beheld his glory" rather than 1:14a, "The Word became flesh" (298). The fact that Jesus" glory is in part revealed, however, does not necessarily lead to docetism, (See Marianne Meye Thompson's The Humanity of Jesus). The divine aspect of Jesus' nature reinforces the humiliation of the crucifixion and the footwashing. The doxa proceeds from the understanding that despite the self-sacrifice and selfabnegation of this person Jesus, $h$ is actions and sufferings reveal that the divine logos has penetrated the physical world. On Johannine christology and soteriology see $S$. Smalley, John--Evangelist and Interpreter (Greenwood, S.C.: Attic Press, 1983) 210-226. Smalley, in part, understands John to portray an "exemplarist view of the cross," so that "Christ's passion and death are seen primarily as revealing the truth that self-sacrificial love lies at the heart of God's dealings with man, and also as an example which Christians are to follow in their own 1 ives and relationships" (226). Following in this vein we may understand the footwashing as the initial phase of Jesus' passion which points forward to his death but also beyond to his resurrection and vindication. (This exemplary interpretation of the crucifixion calls to mind the words of Jesus to his disciples in Mark 10:42-45 par.).

19 Knox says that John had an account of the Last supper with a collection of sayings similar to that in Luke before him. The story of the footwashing is either a legend or a historical record unknown to Mark, according to knox. The latter is less likely, Knox believes, because he feels that such a tradition would also have survived in the synoptics ("John 13:1-30" [HTR 43(1950)] 161-2). Brown notes that a lesson on humility and a reference to the disciples' future in the Father's kingdom or house are common to both 
possibility is that the evangel ist made up the story to illustrate the requirements of the humble service Jesus expects of disciples. Knox, however, believes that the details of $v \vee 4-5$ suggest a primitive tradition.20

We are concerned not so much with the traditions that lie behind the passage, as with its significance for the intended audience of the gospel. What did it mean for them to do as Jesus had done to his disciples? Whatever the source of the episode, it illustrates in a dramatic and compelling way that the service to which Jesus' followers are called may require extreme self-abnegation. If the passage does indeed point forward to Jesus' death in some way, as many, including Brown, believe, then the footwashing presents a similar viewpoint to that found in the synoptic saying that "the son of man came not to be served but to serve and to give his 1 ife as a ransom for many" (Mark 10:45

John 13 and Luke 22 but notes that the wording is very different (557). We shall further consider the episode's relationship to the synoptics below.

20 knox, "John 13:1-30," 162, n.1. Barrett sees the passage as a Johannine construction "based on the synoptic tradition that Jesus was in the midst of his disciples as ho diakonōn (Luke 22.27)" (John, 436). 
par.).21 To serve as Jesus served may require the loss of one's life.

Ecclesiastical practices, both in the past and present, generally have not required that such service be rendered in the sense of actual mutual footwashing amongst Christians. As Brown has pointed out, footwashing never became a sacrament or even a common practice except amongst some of the earliest Christians and some small sects.22 Nevertheless there is nothing in $v \vee 12-16$ which suggests that these words of Jesus should be interpreted symbolically. That modern commentators almost universally understand them

21 Brown says:

[T] The primary reference in 6-10 is to the footwashing as a prophetic action symbolic of Jesus passion and death....In demeaning himself to wash his disciples' feet Jesus is acting out beforehand his humiliation in death... The footwashing is an action of service for others, symbolic of the service he will render in laying down his 1 ife for others (John $x|1|-x x 1,562)$.

Brown cites Hoskyns as one who also interprets the footwashing as symbolic of Jesus' death. The fact remains, however, that the gospel of John expressed the same $\checkmark$ iewpoint as that found in the synoptic texts. Jesus' service unto and through death obliges his followers to behave in a similar way. Mark 10:35-45 par. make this point: such passages seek to arrest personal ambition by advocating service before others and pointing to Jesus as an example of such service.

22 Brown, John $x|1|-x|x|$, 558. The papal practice on Holy Thursday is more in keeping with the Pope's role as vicar of Christ than as a literal interpretation of $v v 14$ 15. It hardly emulates Jesus' requirement of mutual footwashing. See also I Tim 5:10, where again the practice seems anything but mutual. 
in this way reflects a desire perhaps to soften the

distasteful connotations of this passage.23 it is important, of course, to recognize that the gospel of John is full of symbolic deeds and words on the part of Jesus. over and over again Jesus' hearers misinterpret the true import of his acts and admonitions because they cannot progress beyond a literal understanding of what they have heard and witnessed.24

Jesus explicitly states, however, that kai hyme is opheilete allelon niptein tous podas ( $v .14)$. The use of the verb opheilo makes the saying tantamount to a direct command.23 In order for the disciples to have a part with

23 See Bultmann, who says, "Jesus" action is an example binding on his disciples-whereby of course the footwashing is intended as a symbolic act, representative of loving service in general" (John, 475). Others, including Brown and Bernard, simply note that the church never took up the act as a sacrament (Brown, John $X|| 1-X X \mid, 558$; Bernard, John, 465-66). Boismard also notes the same ("Le Lavement," 19). Also see Morr is' caustic note (John $612, n .3$ ).

24 Two primary examples include Nicodemus (3:1-15), and the woman at the well $(4: 7-15)$.

25 John Christopher Thomas says of $v$. 14:

The verb opheilo...highlights the mandatory nature of the act. Opheilo carries with it the idea of necessity or obligation. Its force can be seen from elsewhere in the Johannine literature. According to Jn 19.7, in an attempt to convince $P$ ilate that Jesus should be crucified, the Jews say, "We have (the) Law, and according to the Law he must (opheilei) die..." In the epistles opheilei is used to describe the mandatory nature of moral conduct ( $1 \mathrm{Jn} \mathrm{2.6)}$ and Christian service to other brothers and sisters ( 1 Jn 3.16; 
Jesus they must carry out the same service amongst

themselves to show that "a servant is not greater than $h$ is master" $(\vee 16)$. Thus while Jesus' act itself is symbolic, and may have the sacramental or prophetic connotations proposed by scholars, the command to the disciples, in a sense, goes beyond symbolism. They are to wash each others' feet; in a tangible way they are to become loving servants of each other, in order to honour Jesus' example.26

Footwashing was a common practice at this time and we shall briefly consider the snippets of data that scholars

$4.11 ; 3$ Jn 8 ). The only other time Jesus uses the term in the gospels is also in a context of mandatory service, that of slave to a master (LK. 17.10) (Footwashing in John 13 and the Johannine Community [Sheffield: Sheffield Academic Press, 1991] 109).

26 Thomas disputes the interpretation that reads the call to footwashing as a call to humble service in general. He bases his conclusions upon three reasons:

i) The fact that $v .15$ is so close to the direct command in $v .14$ makes the former a reinforcement of what Jesus charged in $v .14$.

ii)V.16 contains the only instance of hypodeigma on the lips of Jesus in the Fourth Gospel.

$i i i)$ The combination of kathos...kai "emphasizes the intimate connection between Jesus' action (washing the disciples' feet) and the action of his disciples (washing one another's feet)."

Thomas concludes:

The instructions to wash one another's feet are rooted and grounded in the actions of Jesus in vv. 4-10. Therefore, the footwashing is far more than an example.... In all probability, the readers, as well as the disciples in the narrative, would take hypodeigma with reference to footwashing in particular, not to humble service generally (Footwashing, 110). 
believe are pertinent to the question.27 Within the New Testament itself the only other instances of footwashing are found at Luke $7: 35-38,44$ and $I \operatorname{Tim} 5: 10$. The latter text lists the prerequisites for a woman to be enrolled in the order of widows. As well as having raised children, shown hospitality and relieved the afflicted, a widow must have "washed the feet of the saints." The verb used here is niptein, which is the same word used in Jesus' exhortation in Jn 13:14. Bernard sees 1 Tim 5:10 as an aspect of ancient hospitality in which water was made available for guests to wash their own feet upon arrival. He also points to Luke $7: 44$ and several old Testament texts.28 only one of these texts other than 1 Tim 5:10 and Luke $7: 44$ has a second person perform the actual footwashing. 29

27 For an exhaustive survey of "footwashing in the Jewish and Graeco-Roman environment," see Thomas, Footwashing, 26-60. He draws out the connotations of preparation, hospitality and cultic cleansing inherent in the practise.

28 Bernard cites Gen 18:4; 19:2; 24:32; 43:24; Jud $19: 21$; I Sam 25:41 (John, 459). As Hultgren points out only the last of these involves someone else washing an individual's feet ("Footwashing," 541). In this case Abigail, upon being fetched by David's servants to become his wife, says, "Behold your handmaid is a servant to wash the feet of the servants of my lord." This fits in with all of the prior dealings between Abigail and David. She repeatedly presents herself as submissive and humble in order to sway David's judgment. Her offer to wash the feet of David's servants merely reinforces this characteristic. lt emphasizes her humility and self-denial.

$29 \mathrm{Hultgren}$ points out that there is evidence that the Johannine community may have had geographical and chronological proximity to the church addressed in 1 Timothy 
Although these are the only New Testament texts that describe an individual washing another's feet there is extra-canonical literature that describes this service. often the context is one of hospitality and of receiving guests. Interestingly, unlike the Hebrew biblical texts, many of these passages portray footwashing being performed by a second party. 30

We must not, of course, ignore the fact that while footwashing may have become a customary ecclesiastical practice in some communities, the text points beyond this action to promote loving service of all kinds amongst

\section{("Footwashing," 542).}

30 E.g., Plato, Symposium, 175a, 213b. The appropriate passages Huitgren cites from The Testament of Abraham and Joseph and Asenath are more important, however. In the former, which according to Delcor (Le Testament d'Abraham [Leiden: Bril1, 1973] 73-77) originated between 100B.C.E. and $100 \mathrm{C} . \mathrm{E}$. , Abraham himself washes the feet of $h$ is guest (the archangel Michael) although it is his son isaac who is sent to fetch water $(3: 6-7)$. In the second text, which, according to Philonenko (Joseph et Asénath [Leiden: Brill, 1968] 109), originated in Egypt at the beginning of the second century, there are three passages which describe foot-washing: $7: 1 ; 13: 12$ and 20:3. In each passage the phrase niptein tous podas is used. In the first Pentephre, Asenath's father, washes Joseph's feet as a sign of hospitality. In 13:12 Asenath prays that she might become as a slave to Joseph and wash his feet all her life (hina egō nipsó tous podas autou kai diakonesó autoi kai douleusó autoi $\theta$ is tous chronous apantas tes zoes mou). In the final passage, Asenath refuses to allow a maid-servant to wash Joseph's feet, preferring to perform the act herself because haj cheires mou cheires sou kai oi podes sou podes mou, kai ou me nipsei alle tous podas sou. The latter two of these references point beyond common courtesy and hospitality to an attitude of subservience and self-denial in 13:12 and to an expression of deep love in $20: 3$. 
Christians. Nevertheless, Schrage points out "Bultmann's statement that Jesus' washing of the disciples' feet is to be understood as a symbolic act...must not be allowed to spiritualize the exemplary concreteness of this service of love."31 This assertion cannot be emphasized excessively. Christians are called to tangible acts of service on behalf of one another. Even when humiliation is involved they are to recall Jesus" example, for "the servant is not above the master." As Morris states, the disciples "should have a readiness to perform the lowliest service. Nothing was more menial than the washing of the feet.... No act of service should be beneath them."32 While chapter 13 may be interpreted as not requiring actual footwashing, it certainly demands a willingness to perform humble acts of service for others when the situation arises.33 As in the synoptic gospels, the reader who would follow Jesus must not seek to be first and must refrain from self-aggrandizement.

31 Ethics, $307-8$.

32 Morris, John, 621. Barrett believes that the footwashing of 1 Tim 5:10 describes an "accepted metaphor for Christian Service" (John, 443).

33 See Thomas, Footwashing, 127-34 for a summary of the advocates (Tertullian, Athanasius of Alexandria, John Chrysostom, Ambrose, Augustine, John Cassian, Caesarius of Arles) of actual footwashing in the early Church. Although all of these writers are late they demonstrate the pervasive appeal of the concrete act of washing one another's feet as indicative of the humble service of Christians. 
The Benefits of Mutual Service

Jesus performs the footwashing, we read, in order to set his disciples an example and to illustrate that he "loved them to the end" (13:1d). Jesus" service is paradigmatic for the type of love that the disciples are to extend to each other even when it may involve humiliation and degradation. $V \vee$ 15-18 describe the benefits of this mutual service. Jesus assures his disciples that if they understand that the servant is not greater than the master, then they are blessed if they carry out the type of loving service he has demonstrated.34 Jesus' followers, assured of God's love and blessing, should be willing to serve and love each other even to the point of death. Bultmann, as we have noted above, says that the footwashing demonstrates how fellowship with Jesus and fellowship amongst the disciples are inextricably linked. For Bultmann "13.1-20 describes

34 The grammatical problems of the phrase ei tauta oidate, makarioj este ean poiete auta ( $v .17$ ) are great in the sense that the antecedent of tauta is not clear. Commentators agree, however, that the meaning is clear: John 13:1-16, as Morr is says, "sets out principles of conduct and Christ's followers are to act on them" (John, 622). Barrett points to a similar construction at Matt 7:21, 24-7 (John, 444). The call to perform footwashing reflects the attitude of 1 John 3:11-24 which speaks of the blessedness of responding to others' needs. For further discussion on the relationship of the footwashing to the remainder of Johannine thought see below. We duly note Brown's insistence that one should maintain a distinction between "happy" and "blessed" in English translations. He contends that "blessed" should stand for the passive participle eulogetos, while makarios should be translated with "happy" (John XII-XXI, 553). 
the founding of the community and the law of its being."3s

This law requires obedience to God, mutual love and service after the manner of Jesus amongst the members of the community. The primary benefit of fulfilling that law is to become one of the makarioi.

Relationship of the Footwashing to the Johannine Ethic

The footwashing is, in some sense, illustrative of the new commandment of Jn 13:34 in which Jesus instructs his followers to love one another as he has loved them. victor Paul Furnish points out that all the love-commands in the Fourth Gospel occur in the Farewell Discourses of chs 13-17 and that these commands to love one another "are at the very center of the moral and spiritual legacy" of these discourses.36 The footwashing, of course, introduces this important section of the gospel, and Furnish calls this ep isode

an acted parable--or perhaps we should even say, an actual instance--of the divine mission of love for which the Father has sent him. To become a disciple requires, first of all, receiving that love to good effect in one's own 1 ife, but then also acknowledging the commission it lays upon one to serve in love as the Son has served.37

35 Bultmann, John, 479.

${ }^{36}$ Love Command, 134-35.

${ }^{37}$ Love Command, 136 , emphases his. 
This love for one another is a predominant theme throughout the Johannine 1iterature. I John $3: 17-18 ; 4: 7-8$ and 20-21 reveal that mutual love is to permeate the community, based on the example of Jesus as 1 John 3:16 asserts.38 This love is self-sacrificing and is manifested in acts of loving service. The example of christ, not only as the one who washed the disciples' feet, but also as the one who was crucified, who laid down his life for others, is the paradigm that is to direct the disciples' and the community's behaviour.39 This love, for the Johannine community, is the reflection of the glory of the Word made flesh. It derives much of its meaning from the concrete acts that often demand a degree of self-sacrifice.

38 See Schrage, Ethics, 307. He also makes the important point that here, as in Johnn 13, "soteriological and ethical interpretation go hand in hand, so that it is unnecessary to call the relation in John 13 artificial" (that is, the relation between $v v 6-11$ and 12-20). Schnackenberg also notes the exemplar theme as it is picked up in I John 3:16 (Moral Teaching, 324).

39 See Bultmann's comments on 1 John $3: 16$ and 17 (The Johannine Epistles [Philadelphia: Fortress, 1973], 55-56). Also note F.F. Bruce's comment:

No Christian should speak readily of his love for others unless he is prepared, if need be, to show that love as Christ showed $\mathrm{His}$, by giving up his life for them--indeed, by regarding it as his plain duty so to do (The Epistles of John [Grand Rapids: Eerdmans, 1970] 96). 
Limitations upon Service in the Johannine Literature

Biblical scholars are divided as to whether the Johannine ethic and its requirement for love refers only to those members within the community addressed. J.T. Sanders, for example, is adamant that the Johannine love commandment implies that the Johannine Christians are compelled only to love other members of the community.40 $\mathrm{He}$ and others believe that the Johannine literature reflects a narrowing of the apparent universal nature of the love found in the Sermon on the Mount and the parable of the Good Samaritan. within that context, however, the love that christians are to display toward one another, is to be limitless. This is illustrated by the extreme nature of the love described in 1 John. The love the Johannine Christians have for one another is to be founded on the love God has displayed toward them in the death of $h$ is Son $(1$ John $3: 1,16)$. Like Jesus, they are to be prepared to sacrifice anything, including their lives, on behalf of each other. Sanders' evaluation of this love is negative. He sees its intensity as bordering on fanaticism.41

10 Ethics, 100.

41 He says:

Within the church, the love commandment is absolute. As with the original commandment of Jesus of Nazareth to love one's neighbor as oneself, so here there is no compromising, no place for considerations of one's own welfare or even existence... It is a crazy, dual way of 
While sanders has overstated his case it is true that for the Johannine community the commandment to love can be lived out exclusively within the church. Distrust of outsiders is not unusual amongst sectarian groups; in fact it is often the over-riding characteristic of many religious minorities.42 it is this attitude towards outsiders that

\begin{abstract}
behaving towards one's fellow men. The only concern with those outside the church is to bring them into the church, into the unity of faith and love that is the church; within the church, one gives everything for one's brother, whatever $h$ is need, willingly, selflessly, even to the giving up of $i$ ife itself... Here is not a Christianity that considers that loving is the same as fulfilling the law (Paul) or that the good Samaritan parable represents a demand (Luke) to stop and render even first aid to the man who has been robbed, beaten and left there for dead. Johannine christianity is interested only in whether he believes. "Are you saved, brother?" the Johannine Christian asks the man bleeding to death on the side of the road..." If you believe, you will have eternal life," promises the Johannine Christian, while the dying man's blood stains the ground. (Ethics, 97-98, 100).
\end{abstract}

Sander's evaluation of the Johannine ethic here reflects $h$ is agenda with great clarity. (To my mind it is as irresponsible to accuse the Johannine community of ruthlessness in this hypothetical instance as it is to indict all members of a contemporary religious group based on fragmentary evidence.)

42 As Wayne Meeks says:

Recently, sociologists have sought to develop a more inclusive typology of sects by defining them not over against a "church" but over against "the world"--that is, defining their relation to both the social structures of the society around them and the culture or "symbolic universe" of that society. sects 
perhaps explains the implicit restrictions upon the law of love within the Johannine literature.

Schrage also believes that the Johannine ethic reveals a tendency to restrict the law of love to the "brethren" rather than to one's neighbour.43 He finds the explanation for this trend in the suggestion that the Johannine community faced severe persecution from without and their literature presents the results of attempts to "close ranks." He points out, however, that we do not find in John the "sectarian hatred of outsiders found at Qumran: others are not explicitly excluded from love or "hated." 44 Other scholars insist that the gospel and epistles of John do not limit the law of love simply to those within the community.45 As schrage himself points out, albeit somewhat

can thus be identified both in terms of the boundaries they maintain between their membership and the dominant society and in terms of their attitudes toward the world (The Moral World of the First Christians

[Philadelphia: Westminster, 1986] 99).

43 Ethics, $316-17$.

44Ethics, 317-18. See also Furnish, Love Command, 147. Even the Qumran community, like many of their Jewish contemporaries, saw no value in seeking retaliation (I QS 10:17-19). Vengeance was to be left to God.

4 Verhey claims that scholars such as Sanders are arguing from silence (The areat Reversal, 144) and Furnish agrees saying that "the commandment to "love one another" need not be regarded in itself as excluding love for 'neighbors' and 'enemies'" (Love command, 148). Schnackenburg also rejects the "exclusive" interpretation of John (Moral Teaching, 328 ). 
casually, Jesus appears to have washed the feet of Judas, along with the others.46 Thus while some suggest that the Johannine ethic of love is insular and less universal than that of the synoptic gospels, there is little concrete textual evidence to demonstrate that this is the case. Serving the interests of others must not lead to disobeying God; but there are no explicit requirements against showing love to those outside the community if it does not lead to transgression.47 As Schrage says, obedience to God's commandments is very important in the Johannine literature.48 It is only when serving others threatens to

\section{Ethics, 318.}

4 Stricter limitations seem to be in place in the Johannine epistles. Here we find conditions placed upon hospitality to others. Only true Christians may be welcomed ( 1 John 10), although they may be strangers ( 111 John 5 ). it is well to note that those who are to be refused hospitality in $\mid 1$ John 10 are "deceivers" rather than simply "non-Christians," i.e., they are not simply Pagans or Jews, or even as Brown says," "well-meaning Christians who are in error" (Epistles of John, 690).

48 Just how important is reflected in the following sentences of Schrage:

According to John, Christian duty can be summed up in a single phrase: brotherly love. Although the initiative for love clearly lies with God and this commandment does not represent a statutory law, the author does not hesitate to speak explicitly of commandments, both singular and plural.... In the last analysis, the commandments are but a single commandment, and this single commandment is the law of love. "This is my commandment, that you love one another as I have loved you" (15:12) (Ethics, 314). 
lead to disobedience that restrictions are explicitly delineated, as is the case with $\mid 1$ John 10 . There, as Brown says:

If to receive the Presbyter's emissaries is to "become coworkers with the truth" (111) John 8 ), to receive the secessionist teachers is to share in their evil deeds ( 11 John 11) and to become coworkers with deceit.... The inhospitality urged by vv. 10-11 is part of the warfare between Christ and Antichrist, between the spirit of Truth and the Spirit of Deceit (1 John 4:6).49

Specific limitations, therefore, are rare, despite the socalled restrictive ethic of the Johannine community, and there are certainly no prohibitions upon aiding the wounded and dying, Christian or not. One's duty before God must be carefully maintained and requirement of self-denial and service to others must not be allowed to violate it.30

49 Brown Epistles of John, 690-691. Brown continues by citing Matt $18: 17 ; 1$ Cor $5: 4-5 ;$ Tit $3: 10$ and Rev $2: 2$ as further New Testament examples of early attempts to separate former christians from the community.

50 when discussing the so-called restrictive nature of the love described in the gospel of John, Verhey says:

John's distinctive treatment of the love commandment does not license hatred of the enemy or of the neighbor; rather, it focuses on the fulfillment of God's love within the community. Love--even God's love, even agape-seeks a response, an answering love. it seeks mutual love, and where it finds it, the heavenly realm is entered (The Great Reversal, 144).

This idea of agape- as somehow mutual is found in the writings of many scholars (e.g. Gene Outka, Agape: An Ethical Analysis, 37-40.) Outka explores the possibility that the true essence of agape may be what he terms 
mutuality. A relationship between the self and the other in which only one party gives is not one of love. He illustrates this with the more optimistic view that true agape exists when the agent expects a response in $k$ ind from the other. He says, "Agape unrequited appears not to be fully agape, and some mutuality is a necessary condition" (40). Stephen Post in a slightly different context also makes a similar point. He says:

Mutual love or reciprocity is the only appropriate fundamental norm for human interrelations, and for the divine-human encounter as well....Divine love, so often understood as the perfect example to which human love must conform, is mistakenly interpreted as containing no element of selfconcern. This view is based on the false assumption that the divine neither needs nor seeks the mutual good of fellowship with humanity ("The Inadequacy of Selflessness," 213).

Post believes that the 1 ife of Jesus reflects this deep love and desire for reciprocity. He rejects the ideas of those who see the cross and agapē as inexorably linked (he names Nygren, Yoder and Hauerwas) and says that "the cross symbolizes the violation of love more than it does love itself" (221). Reciprocity and mutual love are, of course, to be found throughout the Bible. The entire prophetic tradition calls for some kind of response. The life of Jesus as portrayed in the gospels also envisions a welcoming response as the ideal. The important point, however, is that Jesus is portrayed as insisting on placing the interests of others first and on serving others routinely even in the Fourth gospel. It is a mistake to emphasize the reciprocity of the early christian ethic as it is reflected in the gospels without also noting that self-sacrifice on behalf of others is a fixed principle throughout this literature. James Gustafson notes the pervasiveness of this idea in his book Can Ethics Be Christian? The imperative to seek the good of one's neighbour and the accompanying diminishment of "the centrality that "rational selfinterest' often has in other forms of ethics" is for Gustafson the one distinctive aspect of Christian ethics (164-65). As Furnish says, the New Testament, including the Johannine literature, sees that "love is present where it is 'active' in deeds of mercy and kindness, in the actuality of caring for and serving the neighbor" (Love Command, 202). 
Nevertheless, it is somewhat disquieting to compare the expansive servant-ethic of the synoptic gospels to the Johannine literature and to discover how explicit requirements of service seem to be limited to the Johannine community. Clearly these Christians' relationship with the outside world contained elements of tension which many scholars have tried to identify. While we cannot discuss here fully the nature of the Johannine community and its view of outsiders (and who indeed constitute outsiders) some points can be made.

i. The gospel of John is intimately familiar with Jewish customs and beliefs as practiced in first century Palestine $(2: 23 ; 6: 4 ; 7: 2 ; 10: 22 ; 11: 26 ; 13: 1)$. As W.D. Davies says, after listing these verses, "What is certain is that the author of the Gospel was steeped not only in the old Testament but in the liturgical tradition of Judaism." 1

ii.The gospel of John also uses many Hellenistic idioms to convey its message. The most famous example is, of course, the use of the term logos and the emphas is upon special knowledge that is possible through Jesus.32

iii.The community of the gospel is "neither Jew nor Greek" but one in Christ. Their self-understanding and identity come from their belief in Jesus as God incarnate, York: 31 Invitation to the New Testament (Garden City, New 32 Again see Davies, Invitation, 396-408. 
the bringer of eternal life. Membership is not limited, therefore, to ethnic origin. It is available to anyone who, like the samaritan woman, believes that Jesus is the Messiah.

iv. The gospel appears to have been written for members of the community rather than as an evangelistic tool. Thus John 20:31 is interpreted as a call for increased belief or maintaining one's true belief. The evidence for this cuts both ways, however. H.C. Kee claims that the former purpose is indeed more likely since,

throughout his gospel [John] shows that Jesus' miracles aroused hostility rather than faith among those who were not disposed to see in him the messenger and agent of God. The gospel, then, would be a book for the church, rather than an evangelistic appeal to the world. This impression is supported by the book as a whole, especially in the farewell chapters:

1 am praying for them; I am not praying for the world but for those whom thou hast given me (John 17:9).53

A few passages, however, temper such an interpretation of John's purpose. The most notable is Jn 3:16-17. As Segovia says:

In Jn 3:16 one finds a relationship of love which is not mentioned elsewhere in the Gospel and is, therefore, uncharacteristic of the author's thought: ègapésen ho theos ton kosmon. Indeed, if one recalls the four relationships of love of Jn 13:31-14:31 and the threefold series of subordinate themes of In 14:15-26, the declaration of Jn 3:16 would

53 Jesus in History (New York: Harcourt Brace Jovanovich, 1977) 220 . 


\begin{abstract}
seem to be totally unexpected and surprising, because of those subordinate themes of $v V$. $14: 15-26 \ldots . .1 t$ is the disciples (=those who believe) that God loves, not the wor $1 \mathrm{~d} .54$
\end{abstract}

Whatever its intended audience, the gospel presents the person of Jesus in order to encourage faith in him as the Messiah and logos of God incarnate. The important thing is to act upon this faith by displaying brotherly love.

$v$. The Johannine literature as a whole is clearly the product of a community that saw separation from the world as imperative for salvation. The love God has for the world mentioned in point three above is essentially disregarded in the remainder of the Johannine corpus. Although God is regarded as the creator of the world in the Prologue so that a strict dualism cannot be maintained it is important to note, as Schrage says:

It is characteristic that statements about creation appear only in the prologue and that John's picture of hope has no room for the wor ld; expectation of a restored creation has been totally surrendered. Of course John speaks of God's love for the world (3:16), but the idea expressed in $3: 16$ is not taken up or developed elsewhere, and nowhere are ethical consequences derived from it. 35

The world is the sphere of sin and ungodliness. John's world-view is dualistic in the sense that it contrasts good and evil, light and dark, belief and unbelief. This

34 Love Relationships in the Johannine Tradition (Chico: Scholars Press, 1982) 166.

35 Ethics, 309. 
attitude to the world is perhaps born of the hostility of opponents towards the Johannine community but it leads inescapably to a suspicious, distrustful attitude to anything and anyone who is not a believer.36

vi.Within the community, composed of all who believe, the essence of love means serving the needs of one another. While this may be carried to the extreme of dying for another Christian, Schrage is correct when he expresses reservations about the "new" nature of Jesus' command to love in John.

In John the radical inclusiveness of 'neighbour' found in Jesus has vanished once more. As the object of agape we find neither neighbor nor enemy but other christians ("brother," "brethren"), as in I John, or "one another" as in the Gospel. Various attempts have been made to mitigate this observation, but they are not persuasive. It is not legitimate, for instance, to interpret "brother" as referring to one's neighbors in general rather than to fellow christians. The close connection between discipleship and love (13:35) rules out such an interpretation. One might still ask, of course, whether the analogy to God's love does not imply a universality of Christian love. John $3: 16$, for example, speaks of God's love for the world. 8ut we must remember that $3: 16$ is unique (despite $1: 29 ; 4: 42 ; 6: 33$ ). Nowhere does the Gospel make God's universal love a standard for the life of the christian community. 57

56 Schrage believes that it is indeed persecution that is the historical source for the restrictive nature of love in John (Ethics, 317).

57 Ethics, 316. 
Within the community, however, love and service to others do appear to be indiscriminate. The categories of believer/ unbeliever are far more important to the community than rich/poor, Jew/Gentile, male/female and so on. The servantethic in John does appear to be insular and confined to the community, yet all who believe as the Johannine Christians do, are welcome to enter. In addition, it is an argument from silence to suggest, as sanders does, that members of this community would ignore the needs of outsiders when confronted with them face to face. The life of the community in light of Jesus' incarnation, and the preservation of that life, is the primary interest of the writer. Ethical issues are only of interest insofar as they pertain to the Johannine circle. There is no room for compromise: the dangers that lurk in the kosmos preclude any discussion of moral behaviour outside the community.

\section{Relationship to the synoptic Gospels}

The principle of serving others in the Johannine literature is founded upon the duty to love one another (or "the brethren"). Although, as we have seen, the servantethic is limited to those within the christian community, it is clear that this ethic is fundamental to the selfunderstanding of the Johannine Christians, especially as it is acted out in the footwashing episode. Perhaps the most remarkable aspect of the footwashing is that it serves as 
the counterpart to the institution of the Eucharist found in the synoptic gospels. Despite this difference, the footwashing illustrates how the Johannine ethic of selfsacrifice on behalf of others corroborates the synoptic tradition. Morris notes that in the "synoptic account of the events of this evening we read of a dispute among the disciples as to which of them would be the greatest."58 Morris concedes that John does not include this dispute. He says, however, that the footwashing "rebuked their [ the disciples'] lack of humility more strikingly than any words could have done."59 Although Morris does not understand this to be the primary emphasis of the passage it is apparent that the footwashing reflects jesus' teaching about self-denial as found in the synoptic gospels.

Barrett also sees a relationship to Luke here and suggests that the footwashing is based upon Luke 22:27. Here Jesus refers to himself as ho diakonōn, "the one who serves." 0 Brown notes an even more significant connection

58Morris, John, 612. In fact only Luke includes a dispute about greatness in the account of the Last supper.

59 John, 612 .

60 Barrett, John, 436. Brown disagrees with Barrett's suggestion that the foot-washing ep isode was concocted by the writer of John to illustrate the saying in Luke 22:27. He says:

The genius of the [Fourth] evangelist lies more in eliciting the theological significance of what has come to him from the tradition than in inventing illustrations (John $\times 111$ - 
with synoptic ideas suggested by J.A.T. Robinson. Brown

agrees with Robinson that echoes of Mark 10:32-45 are found in the footwashing episode. He summarizes as follows:

There [Mk 10:32-45], after Jesus had foretold $h$ is death, James and John asked to share his glory. Jesus insisted that they must first share $h$ is fate and be baptized with his baptism; and he stated that the great must be as the servant, and that $h$ is own service consisted in giving his life. Thus there are elements of both interpretations of the footwashing in the Marcan scene. It is interesting that Luke $x \times i$ i 24-26, the parallel to Mark $\times 42-45$, is part of the Last supper scene. ${ }^{61}$

Here Brown highlights how the footwashing confirms the principles of self-denial, self-sacrifice and service that spring up again and again in the synoptic tradition and are most profoundly illustrated in the cross. The stark portrayal of this principle in John 13 is almost starting and perhaps uncharacteristic. Although Jesus affirms $h$ is position as Lord and Master, his actions are self-

\section{$\underline{x}(1,568)$.}

61 Brown, John $x|||-x|-1$, 569. James Dunn also notes the thematic connection of the foot-washing with Mark 10:42-45 ("The Washing of the Disciples' Feet in John 13:1-20" [ZNW $61(1970)] 249)$. He further makes the point that

the parallel with Mk 10.42-45, I Joh 3. 16 , etc shows that those who $f$ ind the meaning only in the moral of $v v$. 12-20 have missed the heart of John's understanding. In short, [they] are mistaken in thinking that the soteriological-christological significance of the first part cannot be harmonised with the moral-ethical interpretation of the second part (ibid, 249). 
abnegating, point forward to his crucifixion, and unquestionably reflect many of the teachings on selflessness that we find in the synoptic gospels. While we cannot be sure that the writer of John knew any of the synoptic gospels, we do know that the requirement of self-denial and routine service to others was widely known in the early Christian communities. Both the synoptic gospels and the Johannine literature record that the cultivation of such an attitude was required by appealing to the words and actions of Jesus. That such behaviour constituted a fundamental part of the earliest Christian ethic is apparent by these appeals to Jesus' authority or example in the traditions about his life. This is especially true when we examine how Christian love is illustrated by concrete acts in 1 and 111 John. 62

Conclusions concerning the Ethic in John

As we acknowledged at the beginning of this chapter, the portrayal of Jesus in the Gospel of John is very different from the depiction of him found in the synoptic accounts. In addition, the ethics of the two traditions reflect different concerns and emphases. This is most apparent when we consider the idea of love and the universalist flavour found in the synoptics as opposed to

$62 \mid$ John $3: 17-18 ;|1|$ John 5-7. 
the more community-oriented accent in the Johannine literature. Despite this and other variations we should carefully note that the Johannine ethic also promotes the routine requirement to place the interests of others before one's own. Like the synoptic tradition it uses the example of Jesus to encourage such behaviour. Not only does the Fourth gospel confirm the synoptic tradition in principle, it illustrates this principle with one of the most striking and compelling episodes in the entire New Testament.

It is largely unresolved as to whether the passage calls for actual footwashing amongst Christians (although it seems that the Johannine community as well as other churches probably did carry out this practice). It is obvious, however, that the passage functions to call Christians to emulate the loving service that Jesus rendered to his followers both during the Last supper and at $h$ is crucifixion. The imitation of Jesus' humble service, even to the extent that one becomes willing to die on behalf of another (John 15:13; I John 3:16), helps to correct any inclinations towards pride or ambition (John 13:16), and also ensures God's favour (John 13:17; I John 3:22). These two themes also arise in the synoptic treatments of the requirement to serve others' interests before one's own. The Johannine literature places few restrictions upon this requirement, provided that by responding to it one does not infringe upon one's duty to God. 
The central ethical principle of placing the interests of others first is clearly preserved in the literature of the Johannine community. Whatever differences these books may have in relation to the rest of the New Testament, like the other earliest Christians, the Johannine literature, as a reflection of a particular Christian community's self-understanding, acknowledges the importance of emulating Jesus' example of serving others. For the Johannine Christians such behaviour was one of the characteristics of those who served God and kept his commandment to love one another as Jesus loved (John 13:367 ). 


\section{THE UNDISPUTED PAULINE EPISTLES AND THE SERVANT-ETHIC}

If one follows Paul's lead... the problem of Christian ethics is not one of creating a distinctive theory in which "the good" is peculiarly different from what others have found to be good. Nor is it one of creating out of the material content of New Testament exhortation whether in the letters of Paul or the sayings of Jesus a system of rules to govern Christian behavior and a technique of interpretation to apply those rules to specific situations. Rather, the problem of Christian ethics continues to be discerning the obligations of walking according to the "desires of the spirit" in very diverse, concrete situations. Paul presumes that one's judgments in such situations are molded by the gospel.1

In his epistles, Paul uses concrete examples to illustrate

his assertion that Christians must adopt a stance that consistently places their own interests after those of others. These examples can be as mundane as calling for respect of the spouse's wishes concerning conjugal relations ( 1 Cor 7:3-4), and as extraordinary as suffering wrong rather than bringing a lawsuit against a fellow Christian ( Cor 6:7). In addition there are some sayings, especially in Romans, that seem to echo the synoptic Jesus.

In Paul, as in the gospels, love is intimately connected with seeking the best interests of others.

1Pheme Perkins, "Paul and Ethics" (Int 38 [1984]) 277. 
Although this love is to be extended first to the members of the community of faith, Paul does not recommend that it be restricted to this group:

It [Christian love] is a radical giving up of one's self and a radical being given over into the service of others.... The Christian's "slavery" to God finds concrete expression in his serving other men. Only in this one respect, but always in this one respect, is he to be in their "debt" (Rom 13:8). The neighbor to whom the Christian is bound in love is in the first instance the brother in Christ. Yet Paul's appeal to the Galatians to "do good...especially to those of the household of faith" (6:10b) defines only the minimum of love's responsibility, not its farthest extent.2

Thus for Paul love is expressed in refraining from selfassertion and serving the interests of others.

The content of the servant-Ethic in Paul

Romans $12: 3-8$

Morna D. Hooker says of Romans 12, "Here, the move from theological argument to ethical problems is plain." 3 It is to chapters 12-15, then, that we should turn to discover the nature of the servant-ethic in Romans.

Romans 12 contains a number of exhortations which are applicable to our study. $v v 1-2$ contain the thematic

2 Victor Paul Furnish, Theology and Ethics in Paul (Nashville: Abingdon, 1968) 204, emphases his. He also cites I Thess $3: 12$.

3 "Interchange in Christ and Ethics," (From Adam to Christ: Essays on Paul. Cambridge: Cambridge University Press, 1990) 56 . 
impulse for Paul's advice here, as he encourages his readers to "stop allowing yourselves to be conformed to this age but continue to let yourselves be transformed by the renewing of your mind so that you may prove what is the will of God, that which is good and well-pleasing and perfect."4 Paul calls his readers to "be transformed" so that they might prove (dokimazó) what constitutes the will of God.5 The result of such a transformation is outlined in $12: 3$ where Paul admonishes the Christian "not to think of himself more highly than he ought to think." As members of one body in Christ (here not the "body of christ"), "Christians, like the various members of a single body... are all necessary to each other and equally under an obligation to serve one another."7 Arrogance, therefore, is prohibited: each member has an important and necessary role.

The list of gifts that follows is interesting because of the seven gifts listed, at least three relate in some way to the servant-ethic: the ones who serve, contribute and

4 Cranfield's translation.

5 The use of the verb dokimazo points to the result of what is being tested--thus it can refer both to the process of testing and the outcome of the test. In this verse the renewing of one's mind that comes about when one is not conformed to this aion leads to 'the discernment of God's will and what is "good, acceptable and perfect."

See 1 Cor 12:27.

7 C.E.B. Cranfield, The Epistle to the Romans II

(Edinburgh: T. and T. Clark, 1979) 618 . 
show mercy. Each of these embody elements of what we may describe as the servant-ethic. The phrase ho proistamenos can mean either the one who presides or the one who comforts, gives aid.8 The important thing, however, is that each Christian is assured of receiving appropriate gifts based on the degree of faith. Acts commensurate with the servant-ethic are manifestations of such gifts.

Romans $12: 9-13$

The discussion of specific gifts is quickly followed by general admonitions to all of the church. These ethical injunctions are terse and lacking in thematic connection, although cranfield would group them under headings such as "Love in Action," or "The Marks of Love."g In all there are thirteen phrases of which three are of an abstract

8 In the context of the structure of the passage 1 would opt for the former (contra RSV) because Paul alternates "formal" gifts (prophecy, teaching, exhortation) with the more unassuming ones of service, giving and mercifulness. Although this pattern is not an exact one of alternation it seems to fit with Paul's insistence that all members of the body are one in Christ. Alternatively, diakonia can be read in the sense of what later came to be an ecclesiastical office (deacon) in which case the "higher" gifts of prophecy, diakonia, teaching and exhortation are listed first followed by the more general ones of giving, aiding and showing mercy. In his short commentary on Romans 12-13, Cranfield is especially non-committal on the meaning of ho proistamenos, offering several options including the ruler of the church, the administrator in charge of charitable work or the rich protector of the church who provided for the poor. of these three options Cranfield seems to favour the second (Romans 11, 625-627). Cranfield sees all seven gifts as being rather formal and referring to particular positions or offices in the church.

9 Romans $11,629$. 
nature $(v .9)$, four describe relations between Christians ( $v v$ $10,13)$, three encourage appropriate behaviour in relation to God ( $v .11)$, and three describe the unwavering faith of the Christian $(v, 12)$. While nothing in these verses specifically speaks of serving others, $v .10$ with its references to philadelphia and showing honour recall our discussion of the Johannine literature. How can one honour one's brother without in some sense deferring to, i.e. serving, him?

Showing honour becomes paramount (proegeomai); love is to be without hypocrisy, "anypokritos" and evil is to be hated (apostygeō).10 As Kasemann says of V.9: It [agapē] is without illusions and ready for demonstrative action, involved in the good which is perceived as necessary and beneficial, and it abhors the evil. Compromising neutrality is excluded."11 If we substitute the phrase "the christian" for "agape" in these sentences we have a portrait of the nature of Christian character Paul is trying to promote in vv 1-13. The Christian is to be a living sacrifice to God;

10 The exact interpretation of tèi timéi, allēlous proegoumenoi in $v .10$ is disputed. The RSV translates it as "outdo one another in showing honour." Blass and Debrunner, however, prefer to interpret proegeomai in the sense of "to" prefer" rather than "outdo" (BDF, 84). it can then be translated: "Concerning honour (or esteem) give preference to the other [rather than oneself]." BAGD suggests, "As far as honor is concerned, let each one esteem the other more highly (than himself)" (706), and see Cranfield, Romans $11,632-33$.

11 A Commentary on Romans (London: SCM Press, 1980) 345. 
this requires a renewal of one's mind and an inner transformation. This is the ground of the ethical injunctions which follow. The self is to be soberly evaluated and become a conduit for God's gifts and love towards others. This selflessness and other-directedness, one of the marks of the servant-ethic in the synoptic gospels, is emphasized in the following verses.

\section{Romans $12: 14-21$}

Verses 14-21 turn our attention outward away from the one body in Christ to those who are indifferent or indeed hostile to Christians. These verses recall Jesus' exhortation to love one's enemies (Matt 5:44; Luke 6:28), although Paul never mentions Jesus explicitly. Persecutors are to be blessed not cursed ( $v .14$ ) and evil is not to be repaid with evil ( $v .17)$. Between these two admonitions Paul encourages his readers to live in harmony with each other and not to be haughty. It is as if he is saying, "If you are willing to bless outsiders who persecute you, as you should, make sure that your own snobbishness and arrogance are not causing the animosity they feel." His insistence not to repay evil for evil could also refer to intra-church conflict in that he does not want one member's unchristian act against another to be compounded by vengeance on the part of the aggrieved.12 To live peaceably with all--(v. 
18; again the focus turns to those without as well as within the community)--is a worthy goal and therefore vengeance is always precluded. Revenge is to be left to ood and the Christian should therefore feed $h$ is enemy as recommended in Prv 25:21.13 In this way Christians overcome evil with good

13 One of the most troubling aspects of this passage is Paul's citation of the passage from Proverbs and its promise that by feeding one's enemy one will heap coals of fire upon his head. Scholarly opinion is divided on this issue. One line of thought believes the coals to represent the burning shame and contrition the enemy will suffer once the love of the Christian is experienced. Barrett, for example, calls the burning coals the "fire of remorse in light of $v$ 21" (A Commentary on the Epistle to the Romans [London: Adam and Charles Black, 1957] 242). Käsemann mentions that the anthrakas pyros was part of an Egyptian penitential ritual involving a forced change of mind (Romans, 348-49). The other way of interpreting this passage reads the burning coals as representative of God's eschatological vengeance which is increased by the kindness of Christians. Piper prefers to see the coals as representative of eschatological judgment. He attempts to bring such an interpretation into harmony with the general principle of enemy love in three ways:

1) Although $v v$ 19-20 appear to endorse $k$ ind acts in order to bring judgment upon the enemy, to call for blessings upon persecutors in $v .14$ "excludes every motive that would desire our neighbour's destruction" (Love Your Enemies, 116).

2) God must eventually avenge evil acts; otherwise faith in him is worthless. To think that God will not repay evil acts means that "faith and blasphemy are for him as good as equal.... If this were true, the hope of the gospel which hangs on God's faithfulness would be shattered. And if the hope of the gospel is shattered, then the ground of enemy love... is lost" (Ibid., 117-118).

3)Piper insists that Paul includes an unspoken conditional clause in 12:20 so that the individual who loves heaps the burning coals on the enemy's head "if the enemy is not moved to repentance by your love." Reliance upon God's righteousness assures the christian that he or she is not ultimately responsible for the fate of the other.

He [the Christian] is now also freed from the insidious tendency in every man to keep an 
account of wrongs ( 1 Cor 13:6) in the name of justice. The assurance that God will take vengeance justly on the evil of unrepentant animosity removes the last hindrance to enemy love (ibid., 118-119).

Thus although Paul says that it is you who heap will the burning coals upon the enemy's head the matter actually resides with God. With this line of argument $P$ iper seeks to preserve the pristine nature of enemy-love in Paul while at the same time respecting the clearest understanding of the text (i.e. that the burning coals do in fact refer to eschatological judgment). For the most part he succeeds, especially when we cast our mind back to Paul's insistence that love be genuine $(v .9)$. Kind acts hardly constitute genuine love if the doer secretly wishes for the destruction of the recipient. Nevertheless there is a problem with the tone of the passage when it is compared to the command for enemy love in the synoptics. In those passages the response and fate of the enemy is not even raised as an issue. The fact that paul mentions the burning coals gives a new connotation to the command. Also see Cranfield Romans II, 648-650. Cranfield, as opposed to Piper, sees the coals as "signifying the burning pangs of shame and contrition.

That, as far as Paul's meaning is concerned, this latter interpretation [as opposed to the one which looks for eschatological judgment upon the enemy] is to be preferred is abundantly clear; for it is congruous with the context in Romans" (649). For Cranfield the suggestion that the phrase points to the future divine punishment of one who does not repent is not tenable in the context of these verses and perhaps the New Testament message as a whole. If doing good to enemies causes their later punishment by God, would they escape such consequences if Christians repaid evil for evil? Also see $K$. Stendahl's interpretation of this passage. He rejects the "penitential option" and notes that

the non-retaliation is undoubtedly based on and motivated by the deference to God's impending vengeance. It is not deduced from a principle of love... The issue is...how to act when all attempts to avoid conflicts with the enemies of God and of $h$ is church have failed (v.17) ("Hate, Nonretaliation and Love: Coals of Fire" Meanings [Philadelphia: Fortress, 1984] 146 .

stendahl calls attention here to the omission of love as a 
and are not themselves overcome. It is now that the strategic motivation of enemy-love may come into play in that Paul seems to understand enemy-love as a way of advancing the gospel.14 This is a motive which we rejected in our examination of the synoptic record.15 Although these verses are reminiscent of Jesus' teaching about love of enemies there is a difference: Paul clearly sees the motive for serving/loving the enemy as one of overcoming evil; as we saw above Jesus never used this rationale as impetus for the command. Despite this apparent difference in motive the teachings of Jesus "are clearly present and Paul has drawn on them, but loosely."16

Chapter 12 of Romans reflects in many ways how the process of being a Christian manifests itself in specific conduct. Much of this conduct is appropriate to the servant-ethic. In the present age, evil and vengeance are to be shunned in favour of fulfilling God's will. Social

motivating factor for kindness to one's enemies.

14 As we have seen stendahl points out that Paul does not advocate love of enemies ("Hate, Nonretaliation," 146) so perhaps a better rendering would be "service to enemies."

15 See above, 67-72. It is possible, however, that $14: 21$ speaks to the need for the believer to overcome the temptation to seek revenge, which is evil, with the call to love one's enemies, which is good, and was, of course, advocated by Jesus. For further comparisons of the command to love one's enemies in Paul and Jesus, see Piper and $h$ is discussion of the intention of the command (Love Your Enemies, especially 111).

16 W.D. Davies, Invitation to the New Testament, 364 . 
prestige is to be rejected. Love and service to others are to be paramount. In this way evil can be overcome not necessarily by eliminating it completely but by forestalling the escalation of enmity. The enemy ceases to be an enemy because he is not hated. The believer who refuses to retaliate against the enemy advances the will of God: "He will be sharing in the victory of the gospel over the world and setting up signs which point to the reality of God's love for sinners; he will be living as one who is being transformed by the renewing of the mind."17

Romans $13: 8-10$

Following a brief discussion of christians' relations with civic authorities, Paul returns to a more personal level. In these verses we find his rendering of the commandment to love one's neighbour. Like Jesus (and R. Hillel18), Paul believes that the commandments of the Law are summed up in Lev 19:18. Love for others is the fulfillment of the Law.19 Paul does not say, however, that love for neighbour is all that is required. It is through

17 Cranfield, Romans 11,650 . V.18 perhaps expands this empathetic approach to the enemy in Paul's admonition to live peaceably with al1. Christians must be careful not to incite their enemies to persecution or to evil acts through deliberate provocation. Christians are partly responsible for the actions and reactions of others.

10 B. Sabb 31 .

19 See S. Westerholm, "Letter and spirit: The Foundation of Pauline Ethics" [NTS 30 (1984)] 243-44. 
love for God that one discerns how to love one's neighbour. Knox calls such love a "concrete living spiritual reality" which "is the dynamic, outgoing reality of God himself... In other words, the love of God is the presence of the spirit of God."20 Thus when an individual becomes a Christian and undergoes the transformation described in $12: 1-2$, he or she passes from conformity to the world to obedience to God. Such obedience is expressed in love and the willingness to set aside one's own interests for the sake of others.21

Romans $14: 1-15: 3$

Following the short, succinct injunctions of chapters 12 and 13, Paul now enters into an extended discussion of inter-personal relations within the church. The first

20 Chapters in a Life of Paul (New York: Abingdon, 1950), 139 .

21 The idea that one is to love one's neighbour as oneself has caused much discussion amongst biblical scholars, theologians and ethicists. Cranfield notes:

It has sometimes been argued that the commandment to love one's neighbour as oneself legitimizes, and indeed actually requires, self-love. The significance of hòs seauton is rather that God addresses $H$ is command to $U$ s as the men that we actually are, the sinners who do, as a matter of fact, love ourselves, and claims us as such for love to our neighbours. And this form of the commandment indicates that the love for our neighbour which is required of us is a love which is altogether real and sincere--as real and sincere as our sinful self-love, about the reality and sincerity of which there is no shadow of doubt (Romans 11,677 ). 
section $(14: 1-13)$ is devoted to warnings against judging one another on the basis of certain personal practices.22 Paul seeks unity rather than divisions within the church. If someone is "injured" by another christian eating a certain food love no longer reigns. Disputes about such things as food should never be permitted to interfere with God's work. Love is active when the interests of others are served. This is confirmed by $v \vee 22-23$ in which the dangers that threaten one who eats while in doubt amount to condemnation. The whole passage is summed up in $15: 1-3$. In these three verses three important elements of the servantethic are outlined:

i)Failings of others are to be borne: Christians do not seek to please themselves. The verb areskō here has connotations of accommodation. Thus when the apprehensions of others lead to personal inconvenience one's own interests are to be put aside. Bauer also suggests that areskō almost means to serve.23

22 For an evaluation of "improper" and "proper" judgment in Paul's thought see J. Paul sampley, Walking Between the Iimes: Paul's Moral Reasoning (Minneapolis: Fortress, 1991) 66-69.

$2{ }^{3} \mathrm{Dal}$ e B. Martin takes up this connotation of the word and notes that the term areskein often means to render service. "It therefore has status implications" and when used by authors from the higher social strata such as Aristotle, "it is a term or shame, referring to servile or fawning people." Martin says that Paul's use of the term challenges popular understanding:

To act for the interests of another was 
ii)One's neighbours are to be "pleased/served" for their own good and edification. This implies that there are situations in which mere accommodation is not to be undertaken--situations in which the neighbour would be harmed in some way.

iii) The example of christ is invoked as one who was not self-serving but bore reproaches on behalf of others. The scriptural quotation from Ps $69: 9$ perhaps is not entirely appropriate, although its context ( $P s$ 69:6-12) may be applicable in some sense to the situation paul is addressing.24 The point of the quotation, of course, is to present christ as the exemplar of humbly putting one's own interests aside.

In the ethical teachings of Romans Paul devotes much attention to inter-personal relations. The unity and

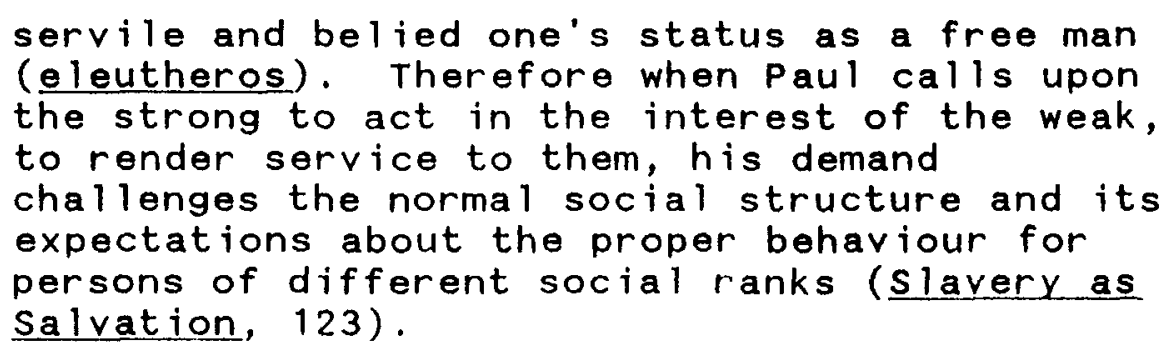

It should be noted that the idea of pleasing/serving the weak is not stated explicitly in 15:1: it is inferred ( $r$ ightly I think), from the consequences of the strong not pleasing/serving themselves. The strong are "to bear with the failings of the weak" and each is to "please his neighbour" ( $\vee .2)$.

24 In these verses the Psalmist prays that he might not be a source of shame or dishonour for others who seek God. It is a prayer for humility and righteousness in the face of opposition. 
harmony of the church depends upon Christians putting the servant-ethic into practice: they are to please/serve others rather than themselves. In Romans, more than any other of his epistles, Paul presents an ethical ideal that is largely unencumbered by reference to particular problems within the congregation. This is not the case in his correspondence to the corinthians and the Galatians.

\section{Corinthians $6: 1-8$}

Paul faces much opposition and conflict amongst the Corinthian Christians. His letters to this community reflect his insistence, however, that no matter how "strong" or "wise" Christians may be, the interests of their fellows are to be paramount. One of the concrete examples that paul gives of deferring one's rights is the challenge to "suffer wrong" rather than bring suit against a fellow christian in pagan court ( 1 Cor $6: 7$ ). Paul's argument becomes more radical as it develops. At first he encourages his readers to avoid bringing the matter before non-christians by finding one within the church who is qualified to decide the matter $(v \vee 5-6)$. In $\vee .7$, however, he says that even to bring a suit against another christian is a defeat, presumably on the part of the one who feels wronged.2s He poses the

25 The word translated "lawsuit" in $v .7$ is krima. This is not the word used in $v .1$ which is pragma and more general. Krima suggests judgment and condemnation of the other on the part of the court. These harsh connotations suggest why Paul sees such an action as a defeat: it is a sign that love has failed. In bringing a krima against 
questions, rhetorical in nature, but also able to cut to the heart of the matter: "Why not rather suffer wrong? Why not rather be defrauded?" In this verse we hear echoes of Jesus' teaching found in Matt 5:39-42, although Paul does not refer to a "word of the Lord" here.26

Some suggest that Paul is offering two methods of resolving the problem. The first involves settling the dispute through some judicial mechanism within the community, while the second involves "turning the other cheek." If $\vee .5$ is understood as ironic, however, only the second option is available. It is possible that when paul says, "Can it be that there is no man among you wise enough to decide between members of the brotherhood?" his implied

another there is no room for the love and conciliation that Paul seeks to $k$ indle amongst $h$ is readers.

26 See Barrett, 1 Corinthians (London: Adam and Charles Black, 1971) 139. As Davies (Paul and Rabbinic Judaism [London: SPCK, 1955] 138) and Longenecker (Paul: Apost le of Liberty [Grand Rapids: Baker, 1976] 189-90) have pointed out there are several verses in Romans $(12: 14,17,21 ; 13: 7,8-10 ; 14: 10,13,14)$ where Paul seems dependent upon Jesus' words. According to Longenecker, however, Paul does not understand the "word of the Lord" to be "law" in the Jewish sense. The tradition of Jesus" teaching "partakes of the nature of a principle; a principle which points the way to the solution in the particular circumstances but which must be applied anew to differing situations" (Paul, 192). Piper also insists that 1 Cor $6: 7$ as well as Rom 12:19, 20 and 1 Pet 2:20 are examples of how the sayings found in Matt $5: 39-42$ and Luke $6: 29-30$ have been incorporated into the paraenetic tradition, although indirectly: "His commands were so specific that they were apparently unsuitable for moral instruction.... Even so his commands control the development of the paraenesis" (Love your Enemies, 59). 
answer is a resounding "yes!" despite the corinthians' high regard for their own wisdom and knowledge 2 .

In his discussion of this passage, schrage takes a more discreet approach. He rejects the suggestion that paul is calling for comprehensive self-denial and proposes that Paul is offering two solutions to the problem and insists that $v \vee 1-6$ juxtaposed with $\vee v 7-8$ show that "paul is not demanding renunciation of all rights as a general rule, but is presenting a choice between two possible courses of christian action." These two courses are the assertion of rights and the renunciation of rights, "a renunciation that... is intended to overcome evil with good." 28 It is not so clear, however, that the juxtaposition schrage speaks of does not demand renunciation of rights. If, as we have said, $\vee .5$ is ironic, then $\vee v 7-8$ offer the only course of action, which is, by implication, to take no action at

27 Barrett raises the possibility of irony here, citing 1 cor $8: 1$, but also says that "Paul may have in mind the Jewish hakam, a scholar of lower grade than a rabbi, capable of acting as judge" ( 1 Corinthians, 138). In response to $h$ is suggestion that 1 Cor 8:1 may be applicable here 1 would suggest 1 cor $3: 18-4: 5$ as more relevant, especially $v v$ $3: 18,19 ; 4: 3$ and 5 . To my mind it is only by interpreting $\checkmark .5$ as ironical that $\vee v 7-8$ make sense. On this view $6: 1-6$ as a unit is not a model for resolving disputes, at least at corinth. That such intra-church procedures were undertaken to settle grievances, however, is confirmed by Matt 18:15-17.

28 Ethics, 193. Meeks also believes that the whole passage is harmonious: "The fact that the second half of the passage (vss. 6-11) chides them for having suits at all and urges an other-regarding ethic that would eliminate such competition does not cancel the practical directive [of $v v$ 2-5]" (The First Urban Christians, 104). 
a11. In addition, there is clear support elsewhere in Paul for leaving judgment and vindication to God even if this means suffering at the hands of another (e.g. Rom 12:17-19). Ideally, Paul wishes the Corinthian Christians to be bound together in love so that law-suits are not necessary. Rather than take a grievance against another christian to court one is to waive one's rights even though it means suffering wrong: "Love cares for others ( 1 Cor 12:25); it does not go to court....It is not legal justice that love rules out, but the self-centred demand for justice as well as injustice."29 This waiving of one's rights in favour of love is therefore concretely displayed when Christians refuse to get bound up in grievances against one another. It confirms the principles expounded by Jesus as recorded in the sermon on the Mount, especially the principle of loving one's neighbour as oneself.30

I Corinthians $7: 4-5 ; 33-34$.

While Paul has some reservations about marriage (7:78), for those who do marry he insists that both parties

29 Schrage, Ethics, 215-216. 216 :

30 See Bornkamm, Paul (New York: Harper and Row, 1971)

The summons to put up with injustice rather than insist on one's own rights, the concluding reminder of the new being which believers owe to grace and which puts them under obligation ( 1 Cor 6:9-11)--all of this is in principle just another way of putting the commandment to love one's neighbour as oneself. 
respect the wishes of the other. In fact, this is one of the drawbacks to marriage since both husband and wife are anxious to please (areskö) the other (7:33-34) rather than being concerned about the affairs of the Lord (merimnai ta tou kuriou). ${ }^{3} 1$ Marital relations, therefore, are to be marked with the same efforts to serve the other as all personal relationships involving Christians. While $7: 3-4$ are probably motivated by a desire to eliminate tendencies amongst certain Corinthian Christians who call for sexual abstinence ( $V .5$ seems to point to such an understanding), Paul clearly believes that the partner who would be celibate must surrender to the wishes of the other. 32 I Corinthians 8 and 10

The issues in these chapters concerning meat-eating and idolatry are too complicated to investigate fully here. Some brief comments are appropriate however insofar as these chapters are concerned with the believer's responsibility toward others.

31 The use of the verb aresko here tempers the connotations of status Martin awards it in Rom 15:1-2 (see above, $n .23$ ).

32 That Paul understands marital rights to be equal for both the husband and the wife in matters of sex is, as Barrett says, a "striking assertion" (1 Corinthians, 156), and militates against the view expressed most vehemently perhaps by George Bernard Shaw that Paul has become "the eternal enemy of Woman" ("The Monstrous Imposition upon Jesus" in The Writings of Saint Paul [New York: $W . W$. Norton and Co., 1972] 299). 
In chapter 8 Paul recommends that his readers not participate in eating meat that is offered to idols since such practice can have a deleterious effect upon the believer's weaker brethren; those who have not yet come to the full realization that idols have "no real existence." Should these brethren eat such meat-offerings they engage in deliberate sin by violating the first of the Ten Commandments. Paul therefore insists that his readers who believe that idols are meaningless should not flaunt this belief if it might encourage others less secure in their faith to eat. Accordingly, the stronger believers should surrender their apparent $r i g h t$ to eat food offered to idols for the sake of others' conscience, especially since they are "no better off if they do [eat]."

In chapter $10 \mathrm{Paul}$ deals with a related problem.

Should members of Paul's readership be invited to dine in an unbeliever's home and learn that the meat has been sacrificed they are not to eat out of consideration for the conscience of the one who informed them (10:28-29a).

Somehow, according to Paul, this preserves the Christian's liberty, and avoids denunciation (vv29-30). Paul w. Gooch says of $10: 29$ :

In the objection "Why should my freedom be judged by someone else's conscience?" ( $v$ 29), there is no reference to the problem of competing moral consciences at all. Rather, Paul's problem is the legitimacy of 
exercising a right when it will harm other people.33

Verse 29 betrays a concern for the unbeliever, assuming

this is the one who announces that the meat has been sacrificed, which is reinforced by $\vee 33$. Paul concludes

this section with a reminder that everything, including eating and drinking, is to be done to the glory of God ( $v 31$ ) and that offence is not to be given to Jews or to Greeks or to members of the church $(v 32)$. He then points to himself as one who does not seek his own advantage but that of many, and exhorts his readers to imitate him (10:3311:1). Paul discusses similar concerns in Romans 14.34 He

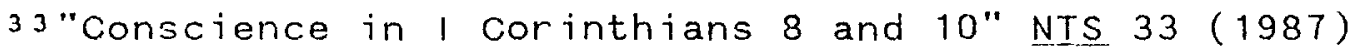
224-254, 252. Verses 28-30 are difficult to interpret but seem to mean that one refuses to eat not because of one's own scruples but because of the other's. (See Barrett, 1 Corinthians, 243). Richardson, however, detects an inconsistency here and wishes to bracket $v v 28-29 a$ in order that $\vee 29 b$ follows on from $v 27$. He says that "It seems that weak Christians were using their weakness aggressively, to keep others from doing things that offended them.... This is illegitimate" (Paul's Ethic of Freedom, 129).

34 In Romans the issue appears to have more to do with the intrinsic cleanness of the food rather than its possible history as a cultic sacrifice. This suggests that the "weak" are of Jewish origin or have been influenced by Jewish Christians, while in I Corinthians the pagan religious milieu sparks the debate. Barrett, however, notes "there is...no definite indication in Rom.14;15 that either idolatry or Judaism is in mind" " "Things sacrificed to Idols," 42.) Also see Cranfield and his commentary on Rom 14:14. He notes that the passage refers to believers who have not yet come to a full understanding that Christ has rendered literal obedience to the law reduntant. They have not yet achieved full liberty in Christ. Consequently, "The meats, which had been forbidden, though no longer ritually unclean in themselves objectively, are still for them, subjectively, unclean" (Romans 11,690-98, and 713- 
seeks to avoid arguments and disputes amongst $h$ is readers by urging those who have no qualms in such matters to respect the principles of those who do. They are to do so out of love for their fellow-Christians, and to ensure that they build up rather than cause to fall. As Gooch has noted:

The limits of freedom for Paul are grounded not in law or rules or regulations, but in relationships. As Christ's slave the Christian is freed from all else and everyone else; but he must have regard for his own good and the preservation of $h$ is freedom, and above al1 he must look to the good of others rather than to his own advantage. ${ }^{35}$

As Krister Stendahl says: "Love allows for the full respect of the integrity of the other, and overcomes the divisiveness of my zeal for having it my own way in the name

14,). In both Romans and I Corinthians Paul recognizes all food as part of God's creation and therefore good. The only thing which overrides this conviction is the misgivings of a fellow christian, or the critical judgment of a nonbeliever. In both cases Paul urges his readers to take care not to cause damage to others' relationship with God, whether real or potential. ( $1 t$ is interesting to note that in Romans 14 paul does not explicitly couch consideration of others' scruples in terms of service. In fact he deliberately avoids such language in $v .4$ with the phrase su tis ei ho krinon allotrion oiketen with the implication that the strong Christian "is not the weak Christian's slave, but Another's, i.e., Christ's (or God's), and therefore not answerable to the weak Christian" (Cranfield, Romans 11 , 703.)

35 (Paul W. Gooch and Peter Richardson, "Accommodation Ethics," 110, emphasis mine.) John $Z$ iesler says, however: "Consideration for others, and their existing or potential adherence to Christ is the guiding rule; in other words, love," (Pauline Christianity [Oxford: Oxford University Press, 1983] 118-9). V.4 simply underlines that the Christian is first and foremost the servant of God, a fact which is manifested in a desire to look to the interests of others. 
of my own integrity." Thus while paul agrees that the liberty one enjoys as a christian brings the privilege of eating whatever one will, that privilege is to be surrendered in the interest of those who have not yet recognized that they too possess it. In essence paul is calling upon "his" followers to adopt a conciliatory attitude towards those who disagree with his position. Personal rights and privileges are to be set aside.

1 Corinthians $9: 19-23$

The requirement to become willing to serve the interests of others is especially illustrated by Paul's statement in 1 cor 9:22 that he has "become all things to all men." Paul says that "though 1 am free from all men, I have made myself a slave to al1, that I might win the more" (1 cor 9:19). This entire passage (9:19-23), serves to emphasize how Paul believes a Christian should behave. Paul's discussion in 1 Cor 8 and 10 brackets his "defence" of apostleship in chapter 9. The three chapters together outline in a concrete fashion how Paul applies the principles of the servant-ethic. On this view $9: 19-23$ is not strictly a defence of Paul's apostieship but an illustration of how the servant-ethic is operative in his own life. As Richard A. Horsley says:

If a concept of "conscience" is emerging in I Corinthians 8-10 then its criterion is not inner freedom based on conviction at all, but the situation and self-consciousness of one's neighbour. Paul's autobiographical 
illustration in 1 corinthians 9 has the same thrust, that is, making the effect on the other into the determinative criterion of one's religious ethical freedom. ${ }^{36}$

It is not completely clear from the passage whether paul believes that such conduct is required of all christians or whether it is part of paul's self-understanding as an apostle. His vigorous defence of his authority which precedes this passage (1 Cor 9:1-18) inclines one toward the latter understanding; but 9:24 suggests that he understands a) Christians to be part of the race and that he paul is but one example of a runner. Richardson believes that it refers only to the position of apostle.37 He says that "paul rarely advises his followers to adopt the same

36 "Consciousness and Freedom among the corinthians: 1 cor 8-10" $\mathrm{CBQ} 40$ (1978) 587. Also see Wendell Will is who says:

Ch. 9 has as its purpose the advancement of the argument about how christians are to express their freedom for the benefit of others. Concretely in chs. 8 and 10 this is a problem of eating sacrificial meat. The discussion of ch. 9 does not function as a defense, and Paul is not really defending $h$ is conduct but is arguing from it... . That is why Paul establishes at length an exousia which he will not use, and concludes by asserting that his motive in rejecting financial support is "becoming all things," which in the question of eating sacrificial meat means consideration of others. In a word, although the word is not used, it is a matter of love ("An Apostolic Apologia? The Form and Function of I Corinthians 9" JSNT, 24 [1985] 40).

37"Pauline Inconsistency: I Corinthians 9:19-23 and Galatians 2:11-14" (NTS 26 [1980]) 356 . 
principle of behaviour that he adopts in 1 cor.9." Richardson also notes that the troubles within the congregations "arise either from obvious moral laxity or from a failure to be accommodating." He concludes that "The basic text on the question of accommodation does in fact provide evidence that Paul did not generally advise his constituency to adopt the same principle as he advocated for himself."38

Richardson points out that chapter 9 is concerned with Paul's defence of his apostleship and this is the context in which $v \vee 19-23$ should be read. He admits that $10: 31-11: 1$ extends "his principle of conduct to $h$ is congregation, but in a weaker and more passive form." He continues:

His reference in 11.1 to imitation invites the Corinthians to adopt for themselves a view similar to Paul's self-understanding but the absence of this motif of adaptability and accommodation in the church would suggest that few accepted his invitation, perhaps because his encouragement to adaptability was not very enthusiastic. In any event, he is much more comfortable with the application of a principle of accommodation to himself than to others. 39

$$
\begin{aligned}
& \text { 3в"Pauline Inconsistency," } 355 . \\
& 39 \text { "Pauline Inconsistency," } 356 \text {. See also Adele }
\end{aligned}
$$
Reinhartz's comments on this verse ( 1 Cor $11: 1)$. She suggests that part of Paul's motive for calling for imitation of himself is the defence of his apostolic authority:

Implicit in this exhortation are the elements of obedience, on the part of the imitators, 
For Richardson, then, Paul's adaptability to the demands of others is a mark of his apostleship which he does not expect his followers necessarily to adopt. 40

We have already noted that the primary concern of chapter 9 may not be a defence of apostleship but rather an illustration of a principle. In an article written in response to Richardson, David Carson approaches the problem quite differently but in a way that also bears on our discussion. ${ }^{4}$ Carson understands 1 cor 9:19-23 to be exemplary rather than a direct call to similar actions on the part of the corinthian Christians. I Cor 9:19-23 demonstrates how a fundamental principle operates in Paul's own life. That principle is not one of accommodation but of
and authority, belonging to the one being imitated....11:1 suggests that becoming an imitator of Paul requires not only humility and obedience; it also requires an eschatological orientation. The true pneumatikoi will do all they can to gain salvation for others ("On the Meaning of the Pauline Exhortation: "mimetai mou ginésthe-- become imitators of me" SR 16 [1987] 398).

For Reinhartz, the exhortations of Paul for believers to imitate him ( 1 Cor $4: 6,11: 1$; Phil 3:17; I Thess 1:6) function as a defence of his right to admonish his readers by illustrating that he himself, in his role as apostle, engenders the very qualities of humility and self-denial that he seeks to promote in his churches.

$40 \mathrm{Richardson}$ suggests that if Galatians is earlier than 1 Corinthians, Paul may in fact have learnt his ethic of accommodation from Peter! ("Pauline Inconsistency," 361, n.43).

41 David Carson, "Pauline Inconsistency: Reflections on 1 Corinthians 9.19-23 and Galatians 2.11-14" Churchman 100 [1986] 7-45. 
seif-denial and servanthood. In Paul's own life this

principle is reflected by his practice of accommodation.

Although chapter 9 may well be a defence of his apostleship, in the larger context of 8-10 it functions as a further illustration of Christians' responsibility to surrender personal rights: "Paul's principle of accommodation is an expression of his commitment in his apostolic ministry not to use all his Exousia." The question in chapter 8 , then is not a call for accomodation but rather a "willingness to abandon personal rights, of which paul's principle of accommodation is a prime example."42

Carson's argument is compelling here, especially in his insistence that these verses offer an example of fulfilling a principle (not of accommodation but of selfdenial), and not an example of normative conduct. He says:

Richardson has raised a valid point: the principle of accommodation is not enjoined on the corinthian readership. But this is not because $\mathrm{Paul}$ holds this principle to be exclusively apostolic, but because paul is simply providing a personal example of that

42 Carson, "Pauline Inconsistency," 15. He also notes

the relation between model and imperative is reminiscent of passages like Mark 10.43-45: the disciples of Jesus are to seek to serve one another, not in the sense that they are to give their lives a ransom for many, but in a way which seeks to live up to the standards of sacrifice set by the son of Man. 
the principle of self-denial which he does enjoin on the corinthian readership. ${ }^{43}$

For Paul there are limitations on how far this principle should be extended, but all Christians are bound to practice self-denial and surrender their own rights, a responsibility which is partly, but not completely,

43 "Pauline Inconsistency," 16, emphasis his. In relation to this question, stendahl has pointed out how dangerous it would be were I Cor 9:19-22 to become itself the principle. Should this happen "it would be abhorrent and certainly lacking integrity" (Paul Among Jews and Gentiles [Philadelphia: Fortress, 1976] 62).

Jacques Ellul also notes how such accommodation to the beliefs and principles of others of which Paul speaks in 1 Cor 9:19-23 can seem repellent. Like stendahl he sees its justification in the primacy of the nature of christian love:

Freedom in Christ will always be regarded [as hypocrisy] by those outside, for it implies an absence of ultimate and total commitment in any human situation. We accompany the other to show our love and so as not to hurt him, but we cannot regard his political and philosophical convictions, in which we go forward with him, as having any final or decisive seriousness. We respect them because they are $h$ is.

It is to be noted that the love of which scripture speaks is love for man, not for ideas, doctrines, social status, political conduct, etc. What counts is man, not revolutions, principles, or ideals. No matter what contemporary thought may suggest, principles are less important than people.... A man is worth more than all the doctrines of justice (The Ethics of Freedom [Grand Rapids: Eerdmans, 1976] 202).

Obviously Ellul understands the behaviour espoused by Paul in the corinthian passage to be part of his own selfunderstanding as a christian and not simply reserved for those who would call themselves apostles. Cultural and social distinctions become irrelevant in light of the gospel. 
demonstrated by Paul's practice of accommodation. The aim of the christian is to fulfill God's will. While 1 cor 9:19-23 illustrates how flexible Paul can become on behalf of the gospel, if such behaviour repels rather than attracts others to christ it is not only redundant but evi1.44 As we have noted above, and as Richardson points out, there are certain practices that paul is unwilling to accommodate unrestrictedly including the role of women, prophecy and tongues in worship. ${ }^{45}$ With Carson we have to iterate, however, that the accommodation illustrated by 1 Cor $9: 19-23$ is not, in and of itself, a principle, but merely the demonstration of the principle of self-denial in Paul's own life.

44 As Richardson suggests, this is perhaps the dilemma that Peter faced in Gal 2:11-14 ("Pauline Inconsistency" $360-362$ ).

45 "Pauline Inconsistency," 356. Troels EngbergPedersen argues, however, I Cor 11:16 illustrates Paul's practice of accommodation. Paul would prefer that the Corinthian women cover their heads during worship and tries to offer a number of reasons for this preference. According to Engberg-Pedersen, 11:16 shows that Paul is not simply resigning himself to the corinthians' stubborness but actually putting into practice the principles he himself has laid out elsewhere in the epistle $(4: 14-21 ; 9: 19-23)$. He understands Paul to be saying in 11:6, "Christians are not contentious--so 1 will not be contentious; I will not insist" ("I Cor inthians 11:16 and the character of Pauline Exhortation" JBL 110 [1991],686, emphasis his). Also see R. Alistair Cambe11, "Does Paul Acquiesce in Divisions at the Lord's Supper?" NovT 33 (1991), 61-70, who argues that in 1 Cor 11:19 Paul is acceding to the corinthians' habit of honouring an elite stratum within their membership. 
Paul does not allow personal scruples or reservations to prevent fellowship with those who will not listen to him. He puts himself at the gospel's disposal, so to speak, and willingly adapts to his neighbour. This precludes the type of division that paul sees at corinth, and the way is clear for the preaching of the gospel. Paul also makes explicit his hope of bringing "enemies" into the community through a strategy of accommodation and charitableness towards nonChristian opponents. 46

The use of the verb douloo, however, suggests something more radical than considerate accommodation to the scruples of others. Paul considers himself a slave to everyone in order that he might serve to win more to the Gospe1. Thus one should read $9: 19$ in the context of $9: 1-18$. Although Paul is free (the answer to his rhetorical question of $v .1$ ), he has deliberately become a slave to everyone for the sake of the gospel.

11 Corinthians $4: 5$

In II Cor 4:5 Paul again speaks of becoming a slave to, or abasing himself before, his readers for the sake of

46 In Romans 12:14-21 he recommends that his readers eschew personal vengeance and instead do good to their enemies. As we noted above these verses echo the synoptic Jesus; but while we suggested in our discussion of the synoptic gospels that there is little evidence of a strategic motive in the sense that such conduct is a way of transforming one's enemy into a friend and fellow disciple of Jesus, Paul sees enemy-love as promoting the potential repentance of the other $(v .20 b)$. 
the gospel. In $v .2$ he asserts that he and his cohorts do not preach the gospel for their own gain. Rather they become slaves of the reader, for Jesus' sake, while they preach Christ as Lord. A similar idea is found in 11:7, where paul asks: "Did I commit a sin in abasing myself so that you might be exalted, because I preached God's gospel without cost to you?" Because Paul was not paid for his preaching he is a slave to those he serves: not only to the gospel and Christ, but also to $h$ is listeners who benefit by receiving the hope of salvation and exaltation. Thus Paul's abasement results in others' exaltation. This is an echo of the idea we saw in I Cor 9:19 in which Paul's willingness to put others first (accommodation) and himself last (abasement) leads to more believers. Paul serves his listeners by bringing them the truth without cost to them. Paul, by his own estimation, has authority over his readers, because he claims full apostleship despite those who believe to the contrary (eg. I Cor 9:2). He manifests this authority, however, by becoming a slave, even a slave to the Corinthian Christians. Despite his arrogance in many things, Paul sees his role as an apostle in terms of service to others. In his commentary on 11 Cor 4:5 Barrett says, "Paul has already renounced the thought of being himself a lord over the Corinthians' faith ( $i .24$, using the verb kyrieuein cognate with the noun kyrios, lord); here he expresses his relation to them positively." (Barrett wryly 
notes that, "Paul was doubtless wise to add that he served them not because they were such pleasing masters, or had in themselves any claim upon him, but for Jesus' sake." 47 II Corinthians $8: 1-15$

Concerning the question of alms and personal wealth Paul does not suggest that believers should surrender all that they have to give to the poor (11 Cor 8:13). He expects his readers to contribute to the collection for the saints, but not to the point of personal impoverishment. Those in the community who are unable to support themselves should be able to rely upon the generosity of their fellowChristians; but Paul insists that each is to earn a living as far as possible (1 Thess 4:9-12). Christian love requires that the believer not only not inflict an undue burden on others but also stand ready to relieve the financial affliction of those in need.48 Nevertheless,

\section{Barrett, The second Epistle to the Cor inthians (London: Adam and Charles Black, 1973), 134. \\ 48 See Eph 4:28; I Tim 5:3-8. See also the apparent} contradiction between Gal $6: 2$ and $6: 5$ which Furnish resolves by saying that "Brotherly love requires mutual caring and serving, but the members of the body retain their individuality and stand always personally responsible under the sovereign law of Christ" (The Love Command, 100). On this assertion by Furnish, Gene outka notes:

Matters are not as simple and uncontroversial as this statement suggests, but it serves nicely, nevertheless, by ascribing importance to care of others and to an individuality and personal responsibility which are always retained and retained by all ("On Harming others" (Int 34 [1980] 386). 
there is in Paul no general exhortation to relieve those in need who stand outside the community: "Paul obviously did not espouse or undertake social action for the benefit of unbelievers on the basis of the fundamentally unrestricted law of love."49 Paul himself has apparently surrendered material wealth for the sake of the gospel and chooses in some instances at least not to earn his living from $h$ is preaching ( 1 cor 9:1-18). He does not, however, extend this idea of deliberate impoverishment into a general principle that all his readers should adopt. Again, the principle of self-denial on behalf of others is to be operative in the life of every believer; but this is manifested in different ways, of which Paul's (and the Macedonians') own practice is only one example.

Galatians $5: 13$

In his letter to the Galatians Paul speaks of how Christian were once enslaved to the stoichea. Now that they have found freedom in christ and walk in the spirit, the servant-ethic is to become operative. In his book the Ethics of Paul, Morton scott Enslin notes:

${ }^{49}$ Schrage, Ethics, 231-232. It is likely, however, that paul would respond in love to a non-believer who confronted him in abject material need, and would expect other Christians to do likewise (Gal 6:10). In addition, Paul saw all his evangelistic activity as a means of service toward those outside the community. Concerning financial well-being, however, his primary concern is to ensure that all the saints have their own needs met (I cor $8: 13-14)$. see Schrage, Ethics, 231. 
Paul, though free, was ready to sacrifice his freedom to the claims of brotherhood; so must the other Christians. Christianity consummated the ethics of self-realization by the ethics of self-sacrifice.... Freedom must never be at the expense of a brother; it found itself only in service.30

While the gospels, especially the synoptics, place the ethical emphasis upon behaviour appropriate to discipleship and following Jesus, Paul's ethical concerns are bound up with instilling the values of the Christian community within his readers who are one in the spirit. In Paul, becoming a member of the body of christ is akin to the decision to become a disciple in the gospels, and is the primary impetus for his ethics. Although free in christ, Paul insists that Christians must "become as slaves to one another" (douleuete allèlois, Gal 5:13). The freedom one finds as a member of the body of christ is expressed through service to others in love.51 One's own rights and interests are to be subjugated to those of others in a way that recalls many of the gospel passages examined above.

Gal 5:13 functions as a central text when examining the idea of service to others in the Pauline literature. Its context includes many themes found throughout the

50 (New York: Abingdon, 1957) 243.

5 I Franz Mussner, in his book Theologie der Freiheit nach Paulus (Freiburg: Herder, 1976), puts this most succinctly in his comments on Gal 5:13: "Wirklich frei ist nur der Liebende, weil er frei ist von sich selbst. Liebe bedeutet Befreiung vom I ch" (36). 
writings that bear $h$ is name, including law, unity, freedom and love, while the text itself is one of the clearest expressions of the principle to place the interests of others above one's own.52 In Gal 6:2 he urges them to bear one another's burdens and thereby fulfil the law of Christ. Both Gal 5:13 and 6:2 illustrate the principle of walking in the Spirit (Gal 5:25). While 5:13 is paralleled by the injunction to "love your neighbour as yourself" which is, in fact, the fulfiliment of the whole law (5:14), Paul suggests that the Galatians are having difficulty within the church controlling their interpersonal relations $(5: 15)$.

Richard B. Hays, in his essay "Christology and Ethics in Galatians: The Law of Christ," has shown that Gal $5: 13$ fundamentally illustrates how Paul's ethics proceed from his theology. He reminds his readers that paul wrote his letter for a community but that contemporary interpretation of the epistle is coloured by post-reformation scholars who read "the text through a hermeneutical filter that highlights the relation of the human individual subject to God."53 Hays seeks to balance this tendency by recalling that paul

52 Enslin says of Gal 5:13: "Here is the kernel of his social ethics with its intimate connection of love and service, forbearance and freedom" (Ethics of Paul, 242-3).

53 CBQ 49 [1987] 271. 
addresses the Galatians corporatelys4 and that this is illustrated by 5:13 which constitutes "an integral part of his theological vision...set forth in opposition to the prospect of using freedom as an opportunity for the flesh,' which means, in Galatians, as a cause of division in the community." For Hays the vice and virtue lists of $5: 16-24$ emphasize the need for unity especially since they are bracketed by 5:13-15 and 5:25-6:5 which are "clear directives against conflict in the church." The interests of the community are always to be placed before the interests of the individual. "The conformity of the Galatians to christ is to be expressed in their communal practice of loving mutual service. It is in this context that the exhortation of $6: 2$ occurs: 'Bear one another's burdens and so fulfill the law of christ." "s

In Gal 5:13 paul telis his readers that although they were called to freedom they are not to use their freedom as an opportunity for the flesh. They are to be servants of one another. Paul uses the verb douleuo to express this thought, which literally means "to be a slave" or "to be

S4 1 am not sure that Hays succeeds totally. Ultimately the community depends upon individuals to bear each other's burdens, become slaves of each other and eschew the vices of 5:19-21. When one member fails it is up to the others to restore that person "in a spirit of gentleness."

$5 s$ "Christology and Ethics," 286, emphasis his. Hays's article is also illuminating on the question of imitatio Christi as a motive for Paul's call to self-sacrifice and service to others. 
subject." F. F. Bruce describes this slavery as completely different "from that against which he otherwise warns them." Bruce continues by saying:
It is as though he [Paul] said, "If you must live in slavery, here is a form of slavery in which you may safely indulge--the slavery of practical love for one another." One could similarly envisage him as saying, "If you must live under law, live under the law of love-- that is, the law of Christ"... This slavery, this law, are impelled by the spirit within, not imposed by an external authority.56

The question remains, however, what exactly paul envisions when he tells the Galatians to be as slaves to one another through love. Clearly, they are to express their love by being of service rather than harming each other, but how are they to become each other's slaves?

In chapter 4 of Galatians Paul has spoken of how the Galatian Christians were once slaves to the "elemental spirits of the universe" but have since become sons and heirs of God; they are no longer slaves (4:7). Before the work of Christ people were enslaved in ignorance of God and his grace. Now Christians are free, liberated by Christ, and must "not submit again to a yoke of slavery" (Gal 5:1).

In all this passage (4:1-5:12) the emphasis 1 ies upon preserving the freedom of christ. The words douloi, douleia and douleuō describe the state of those who have not yet become christians. Yet in 5:13 the verb is used to

56 F.F. Bruce, The Epistle to the Galatians (Grand Rapids: Eerdmans, 1982) 241. 
describe the state of Christians toward each other "through love." The freedom received from Christ is not to take the form of 1 icentiousness but is to become yet another form of slavery. Christians are now to bear one another's burdens (Ga) 6:2) and thereby fulfill the law of Christ. This law is summed up in the entreaty to love one's neighbour as oneself which Paul uses to justify the mutual service he insists upon in $5: 13.57$

Rengstorf, in his article for IDNT, suggests that Paul uses the term eleutheria "freedom" only in contrast to Christians' former state of douleia. That Christians are now sons and heirs of God does not mean that they are

37 Burton's comments on the phrase "but through love be servants of one another" are important to note here. He sees $5: 13$ as a means of overcoming "the harmful restrictions of legalism and the dangers of freedom from law." Love, in the form of mutual service typifies the Christian's freedom:

Having urgently dissuaded the Galatians who were formerly enslaved to gods that are not really gods from becoming enslaved to law $(4: 9,5: 1)$, he now, perhaps with intentional paradox, bids them serve one another, yet clearly not in the sense of subjection to the will, but of voluntary devotion to the welfare, of one another.... The present tense of douleuete reflects the fact that what paul enjoins is not a single act of service, nor an entrance into service, but a continuous attitude and activity (A Critical and

Exegetical Commentary on the Epistle to the Galatians [Edinburgh: T. and T. Clark, 1921] 293).

Burton also points to Mark $9: 35$; $10: 43$ as expressing a similar idea and notes that there diakonos rather than doulos, is used. 
totally independent. "The attainment of huiothesia does not mean the attainment of autonomy in every sphere of life, in relation to God as well as to sin." The freedom achieved is reconciliation rather than the previous state of separation. This new relationship finds expression in the demonstration of hypakoe towards God by those who are liberated through christ. "Thus the new state of the christian comes under the thought of service, though in a very different sense from the earlier usage." 58

Thus when Paul tells the Galatians to "become slaves to one another" through love, he means that they are to be willing to serve each other with no thought for themselves. By so doing they will respond appropriately to their call to freedom and also clear up the divisiveness within the community.

The language Paul uses here is, however, even more radical. Despite Burton's attempts to interpret douleuo in this passage as having less to do with subjection and more to do with rendering service, the verb is extreme. Betz suggests that this has to do with the paradox that paul is intentionally creating in this passage. On the question of why paul calls this new state of mutual love a state of slavery Betz says:

Love is voluntary and reciprocal, but it involves commitments to be maintained even

$$
58 \text { Rengstorf, "doulos," } 274 .
$$


under difficult and strained circumstances. it is the necessity of commitment and the difficulties of maintaining human relationships that cause paul to describe the free exercise of love as a form of mutual ens lavement. 59

Although this verse does speak of reciprocity as part of the paradox of becoming a slave to others in love and freedom, 1 think Betz emphasizes the mutual aspect too much. 1 do not believe that Paul uses the verb douleuo because of the "difficulties of human relationships." The freedom that Christians have been called to is new life in Christ: a life of selflessness and other-directedness, which automatically places them at the disposal of others. A community of Christians, therefore, is ideally made up of persons "enslaved" to each other, but even if some relationships are not fully reciprocal the attitude should be maintained.

Philippians $2: 1-5$

Paul encourages his Philippian readers to "unity of mind" several times in his epistle to them. Again, they are to look to the interests of others in order to maintain this unity. The first part of the second chapter of Philippians is Paul's impassioned plea to his readers for unity. The inclusion of the christological hymn ( $v v 6-11)$, in Paul's mind plays a role in underlining the viewpoint put forward in $v v$ 1-5. Paul calls the Philippians to work out S Qalatians (Philadelphia: Fortress, 1979) 274. 
their salvation ( $v 12)$ by maintaining their unity "being in

full accord and of one mind" ( $v 2)$. Verses 3 and 4 te 11

them to "do nothing from selfishness or conceit, but in

humility count others better than yourselves. Let each of

you look not only to his own interests, but also to the

interests of others."60 He continues the thought with $\vee .5$

(touto phroneite en hymin ho kai en christói lesou) which

has caused many exegetical headaches because the

interpretation of the hymn that follows depends, in large

part, upon one's understanding of this verse. The first

60 The Greek here, as F.W. Beare points out (A

commentary on the Epistle to the Philippians [London: Adam and Charles Black, 1959] 73), is vague: më ta heautón

ekastos skopountes alla kai ta heterón hekastoi. The

meaning, however, is clear: the Philippians are not only to

be concerned about their own interests ( $r$ ights/affairs/

things) but also the interests of others.

Martin rejects the interpretation that $P a u l$ is

encouraging his readers to remember their responsibility to seek the best interests of others in favour of one which understands the phrase to encourage the Philippians to regard each other's way of life as motivation in their own christian walk:

The verb skopein always has a definite object in its sights and means "regard as your aim" (Lightfoot). Then, Paul is advocating that his readers $f i x$ their gaze on the good points and qualities in other Christians; and, when recongnized, these good points should be an incentive to our way of 1 ife. The negative side to this admonition is that christians at Philippi should not be so preoccupied with their own concerns and the cultivation of their own "spiritual experience" that they fail to see what plainly should be evident for emulation in the lives of their fellow believers (Philippians [London: Oliphants, 1976] 90). 
four verses, however, clearly encourage Paul's readers to practice the servant-ethic because they are christians.

This is the implication of verses 1 and 2 . If the work of Christ is operative in Philippi (Ei tis oun paraklēsis en Christōi, ei ti paramythion agapēs, ei tis koinōnia pneumatos), Paul's joy will be "complete" when the Philippian Christians are of the same mind (to auto phronete), have the same love, are in full accord and of one mind (to hen phronountes) ( $(2) .61$ This will be evident because of the Philippian Christians' humble regard for each other.

The Motives for the Pauline Servant-Ethic

We can identify at least four motives for the Pauline call to serve others and to place their interests first. One of the most important of these is to maintain unity within the Pauline communities and also within the Christian movement as a whole. Often this motive is cited in the face of a specific conflict that has arisen, either

61 Clearly, Paul's multiple use of cognates of the verb phroneo in this passage (and Phil $1: 7 ; 3: 15,16,19 ; 4: 2$ ) reveals an interest in encouraging unity, especially since all of the uses of the verb push for unanimity $(1: 7$ and $3: 19$ excepted). Sampley sees in the use of this verb correspondence with the Roman idea of societas or partnership concerning a central purpose. "As long as all the partners are disposed in the same way, the contract continues. Societas terminates with the loss of unanimity, singlemindedness, among the partners" (J. Paul Sampley, Pauline Partnership in Christ, [Philadelphia: Fortress Press, 1980] 62). 
internally or as opposition from outside the community. A second motive is the promise of reward, although this is rarely the only incentive given in any passage. A third reason is the challenge to imitate christ in his humility and service on behalf of others. Finally, and perhaps most important for Paul, is the desire to display appropriate behaviour "for the sake of the gospel," or Jesus. Behind al1 these inducements, however, is the Christian experience of new life in the spirit. The old ways and customs are discarded and replaced by the new reality of 1 ife in christ. Service to others for the sake of Christian unity

For Paul, the unity of the church is one of the most critical issues faced by the early christians. It is clear from his letters, especially those to the Galatians and Corinthians, that he himself has become a focal point for certain divisions within the church. In I corinthians 9 he seeks to overcome his opponents' denunciation of him both by asserting his apostolic authority (9:1-18), and by reminding his readers of his conciliatory attitude towards the views of others (9:19-27), even the views of those outside the community. 62

\footnotetext{
62 Ben Meyer explains I Cor 9:19-23 as an illustration of how Paul reconciled the demands of various factions within the Christian community. He overcame factionalism by distinguishing between unity and uniformity. Meyer portrays Paul as one who recognized that full uniformity between Jews and Gentiles was impossible although paul himself could accommodate both groups (1 Cor 9:23). Ultimately "Christian identity--obviously more fundamental in Paul's view than the
} 
It is also clear that paul realized that his mission caused a certain degree of tension in his relationship with other apostles but he is careful not to speak of such strain as decisively affecting the unity of the church.63 When

diverse self-understanding that qualified it--was correlative to 'the gospel' in whose name Paul accommodated himself to al1 (The Early Christians [Wilmington, Delaware: Michael Glazier, 1986] 184). This question of unity versus uniformity is important because we need to determine how far diversity could extend without compromising unity. As Meyer says the New Testament writers "recoiled from division." christian unity was sought by all of them and was promoted through baptism and the eucharist. "Christian identity, rooted in the experience of salvation, correlative to the gospel, susceptible of diverse self-definitions, open to progress as to regress and collapse, grounded the possibility of the unity passionately sought by Paul" (ibid., 203). It is by acceptance of the gospel, as preached by paul, that one enters new life in Christ. Upon experiencing this new existence Christians, according to Paul, discover the freedom in christ that leads to serving others. There is room for diversity (in practices such as eating meat, celebrating holy days, female dress), but only if such matters do not compromise the truth of the gospel. When the servant-ethic is practised such diversity should not threaten the unity of the community because each will seek to serve the interests of others.

- Graham Shaw observes that "calls for unity are often most vigorously made by those whose activity is peculiarly divisive." He believes that Paul himself must take responsibility for much of the problem: "He cannot, for instance, resist distinguishing himself from all the rest of God's workers in the Corinthian vineyard.... Even in $h$ is exhortation to unity, Paul draws attention to his own special position" (The Cost of Authority [Philadelphia: Fortress, 1982] 62-63). We must remember, however, that Paul faced opposition in Corinth, which manifested itself, at least in part, as an attack on the authenticity of his apostleship. These attacks seem to have been made subsequent to Paul's initial mission to corinth. Paul is convinced that he carries the true gospel-message and that $h$ is authority resides in position as a valid apostle. He is not so much concerned with attacks upon himself (if he were he would have abandoned his mission long before), but rather the dangers inherent if the Corinthians abandon the truth. 
discussing his visit to Jerusalem in Gal $2: 1-10$ he emphasizes the cordiality between himself and the christian authorities in Jerusalem. They were in full agreement on the substance of his message, the legitimacy of his message, and that he should remember the poor $(v, 10)$. In his other letters Paul gives the impression that he was extremely conscientious in fulfilling this latter obligation, and concerning the collection for the saints, the passages from Romans and $I$ Corinthians are most intriguing because they speak of Paul travelling to Jerusalem personally to deliver the money. In Romans he acknowledges that he risks endangering himself if he appears in Jerusalem (Rom 15:31), while in 1 Cor $16: 3-4$ he contemplates sending delegates but promises to go himself if necessary.64 While the other

64Cranfield resists the interpretation of Rom 15:31 that sees evidence here of serious tension between Paul and the Jerusalem church. The anxiety paul expresses about his service being acceptable for Cranfield is natural apprehension that anyone experiences whens embarking on a benevolent campaign. He wryly notes:

Some tension there undoubtedly was; but any one who has had any considerable experience not just in organizing a church's collection of money for charitable purposes but also in the actual passing on of it to those in need will know full well that its being euprosdektos is no foregone conclusion, and will be more likely to recognize in these words evidence of Paul's spiritual and human sensitivity and freedom from self-centred complacency than to draw from them any confident conclusions about the tenston between the Jerusalem church and Paul (Romans 11,778 , emphas is mine). 
passages we have cited reveal Paul's concern for the poor his insistence on going to Jerusalem himself is puzzling. Longenecker believes that the solution to the problem lies in Paul's desire to act as a unifying force in a Christianity that is becoming more and more fractured. For Longenecker "In his [Paul's] determination to present the contribution personally, we see his willingness to sacrifice himself, if need be, for the unity and welfare of the Church."6s

This concern for unity is especially apparent in Paul's insistence that christians place the interests of others first and act toward others in love. In this regard certain issues and principles sometimes should be discarded in order to prevent disputes and divisions amongst

Christians. This is clearly illustrated in the discussion of eating sacrificed meat. One is not to flaunt one's own convictions if by so doing one damages the faith or conscience of another. For Paul each member of the body of Christ is responsible for the well-being of the others.6 6

\section{${ }^{6}$ Paul. Apostle of Liberty, 229.}

- Schrage points out that in some cases the primary concern is to be for the other person and not necessarily for God. He says that "Above all Paul sees conscience or its dictates as being limited by love. " The question of eating meat offered to others "is decided ultimately by reference to others, not to God. Paul states explicitly that love can even lead one to forgo what one's conscience has determined to be necessary and proper (1 Cor 8:2)" (Ethics, 196). Paul would not, however, have acknowledged such a dichotomy. He sees Christian service to others as 
In I Cor 12:12-26 Paul underscores this mutual dependence by emphasizing the inter-relatedness of all parts of the body. He notes:

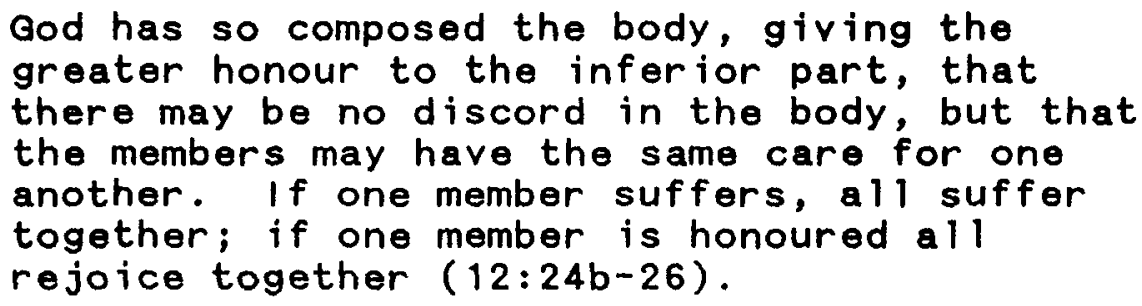

In Paul's view the church is a community of disparate but united elements who depend upon and care for each other. There is no room for self-assertion or personal ambition. Nevertheless, the unity of the community also depends upon a degree of selflessness that is not hindered by a lack of positive response. In other words, while mutuality is clearly the ideal after which paul encourages $h$ is readers to strive, he recognizes that often acts of personal service and self-denial on behalf of others were scorned or rejected even by those within the community. The hymn to love in 1 cor 13 underscores that such rejection is to be borne patiently, for love bears, believes, hopes and endures all things $(13: 7)$. Within the community this love is expressed in acts which continually seek the edification of the church as a whole. Anything which could undermine the community is to be forsaken, even if this means forsaking one's own rights and privileges. Again Paul is an example evangelistic activity. 
of this ( 1 Cor $9: 12-15 a)$. While Paul encourages a

reciprocal attitude among Christians he contends that when

reciprocity fails it is the task of each christian to

continue to act out of love:

It [love] expresses itself not in mere feeling

or inclination but in concrete acts of

service. While it delights in reciprocation,

love gives itself to others irrespective of

the reaction it receives. 67

I Cor 6:1-8 illustrates how far paul believed this

principle should be carried.

Phil 2:1-5 is also an important text for considering Paul's efforts to maintain church unity by means of the servant-ethic. J. Paul Sampley speaks of this unity in terms of Roman law and calls the relationship paul maintains with the Philippian Christians a societas, or legal partnership, which has become societas christi, or partnership in Christ. Phil $2: 1-5$ is for sampley a prime example of how Paul incorporates societas language into his paranesis. He examines the structure and content of each verse to demonstrate how they point to the Roman concept of societas. Of Phil $2: 4$ he says the following:

Self-seeking or looking to satisfy one's own needs is ruled out of order. A countersuggestion is put in its place: seek the things that serve others. The societas that Paul sees at work in Philippi maintains its unity, its love, by avoiding selfishness and conceit. This societas works as the

67 Robert Banks, Paul's Idea of Community (Exeter: Paternoster, 1980) 58. 
individuals, in humility, reckon others better than themselves, as the individuals give up their own self-seeking and concern themselves for the needs of others in the community of bel ievers.68

Although Sampley's goals differ from ours here, he understands Paul's challenge to the Philippians to lead to the same result: a community (or partnership) of Christians who have renounced self-interest in favour of maintaining harmony within the community:

In Christ, Christians are given to one another. In Christ, Christians are freed to seek the best for others. Paul finds societas concepts such as one-mindedness a viable way of expressing what he and the Philippian Christians know to be true about themselves in Christ. In the process, Paul uses the hymn of 2:6ff. to remind the Christians that their 1 ife in the community has christ as its foundation. Only in Christ is it possible. If all the Philippians abandon seeking their own self-interests and turn in service to one another, then they will be truly of one mind. The societas is indeed societas christi.69

For Paul, diversity in and of itself is not to be rejected in favour of uniformity. Unity, however, is of paramount importance. Gal $3: 28$ perhaps captures this aspect of his thought. Social status, race and sex are no longer grounds for making claims upon God, and therefore have no inherent significance. They do not have to be ignored, however, and Paul nowhere insists that they ever should be.

- Pauline Partnership, 66.

- Pauline Partnership. 67-68. 
Being in Christ overcomes any diversity and provides the bond of unity.70

The promise of reward as a motive for service to others

The entire Biblical tradition has a legacy of looking to the humiliated and lowly and identifying them as God's own people. This trend is especially pronounced in the wisdom literature but is evident from Genesis through to the end of the New Testament. In his book on humility Klaus Wengst gives a succinct if less than exhaustive view on the role of the oppressed in the "Old Testament-Jewish Tradition."7l One of the most powerful themes in the Hebrew Bible is that God favours the cause of the oppressed and the poor. This motif is also used by Paul as he seeks to encourage the "servant-ethic" amongst his readers.

For Paul the element of reward in terms of God's exaltation of the lowly is also a prominent theme, although Paul himself never quotes verses such as Prov 3:34 directly. In terms of the servant-ethic the hope of eschatological reward is cited as a motive in such passages as Rom 12:12; I

$70 \mathrm{~J}$. Paul Sampley sums up Paul's appeal for unity despite diversity by noting that paul never calls for uniformity and in fact seeks to preserve variety and to honour differences. Excessive individualism is kept in check by means of love which is "careful consideration for the well-being of others." Although the Pauline communities lack uniformity, "Love makes genuine community possible by recognizing and preserving the common bond that otherwise very different and differentiated people have in Christ" (Walking Between the Times, 62 ).

11 Humility: Solidarity of the Humiliated, 16-35. 
Cor $6: 2-3,9-11 ; 9: 23-27$; Gal $6: 6-10 ;$ I Phil $2: 1-12.72$ In Rom 12:12 Paul tells his readers to rejoice in their hope amidst his general ethical exhortations. In cor 6:2-3 and 9-11 he reminds his readers of their future role in an attempt to overcome the divisiveness of their lawsuits. In 1 Cor 9:23-27 paul says that he has become al1 things to all men so that he might share in the blessings of the gospel and follows this with the analogy of the race and the sacrifices that must be made to win. In Gal 6:9 Paul

72 As Furnish says, "The Jewish doctrine of recompense is by no means absent from Pauline teaching, "Theology and Ethics, 119 and he cites as evidence Rom 2:6-10; 1 Cor $3: 13-15$ and 11 cor 5:9-10 which are not explicitly related to the servant-ethic. Furnish seeks to overcome the inherent tension between recompense and the doctrine of "justification by faith" by noting that "The good works Paul commends are not regarded as having a value in and of themselves. They have value only as responsible acts of obedience to the sovereign Lord." Eternal life is not the "wages" of obedience. "Rather, eternal life, participation in the Lord's victorious reign over all things, inheritance of his kingdom, is bestowed as a free gift from God himself (Rom 6:23) (Theology and Ethics, 121, emphasis his). 1 am not sure that a non-Christian Jewish contemporary of Paul would not speak in a similar fashion. E.P. Sanders notes that "the concern that, in doing the law, one do so with the right attitude of devotion to God was doubtless present in the synagogues of the first century" (Paul, the Law and the Jewish People [Philadelphia: Fortress, 1983] 156) and that "surely non-christian Jews saw themselves as remaining in the grace of God by remaining loyal to the covenant" (lbid., 157). Finaliy:

For a modern theologian to say that in fact the fault of the Jews was that they were selfrighteous he must not only share Paul's assumption that rejection of christ is rejection of grace, he must then add the assumption that Jews rejected grace because they preferred righteousness by merit (Ibid., 157, emphasis Sanders'). 
concludes his paranesis with the assurance that "we shall reap [eternal life $v .8$ ], if we do not grow weary." The hope of God's approval is interwoven in Paul's calls to put aside the interests the self.

The idea of the exaltation of the humble is prevalent throughout the New Testament. Whether or not specific biblical texts are used to support a particular writer's assertion of this principle it is clear that the early Christians were exhorted to service, sacrifice and humility because this would guarantee them God's favour. Serving others as imitation of christ

The question of how, and indeed if, Jesus as the Christ plays a paradigmatic role in the writings of paul has engendered much scholarly debate.73 Texts such as Phil 2:511, I Cor 11:1 and Rom 15:1-3a seem to give Christ the role

730 why some object to the notion that the New Testament speaks of the imitation of Christ, John Webster says:

Above all, the language of imitation appears to detach moral obligation from the objective accomplishment of human righteousness in christ and so to cut the christian life adrift from election and justification.... Imitation language, then, is frequently criticised for a failure to root ethics in soteriology. In so doing it may, it is suggested, direct our attention towards the actions of men rather than the prior actions of God ("Christology, Imitability and Ethics" SJT 39 [1986] 312313).

(Paul's supposed disinterest in the earthly Jesus is another reason that some hold that the idea of imitatio christi is not really operative in his writings.) 
of exemplar. Many scholars, however, dispute that Paul was actually suggesting that the figure of Jesus somehow provides an ethical pattern.14 Hays notes that the position of Davies and C.H. Dodd on the meaning of the "law of Christ" in Gal 6:2, which understands the phrase to mean a new messianic Torah, has led to a backlash. This backlash "has caused many interpreters to reject altogether the possibility that Paul might intend to suggest in this phrase some distinct normative function of the figure of Jesus Christ for Christian ethical behaviour."7s schrage tends

74 See Schrage, Ethics, 207-208. He cites W.D. Davies who maintains that paul does not artificially separate the teaching of Jesus from the person of Jesus: "He [Paul] holds up certain qualities of the historic Jesus which were to be imitated" (Paul and Rabbinic Judaism, 147). Davies cites Rom 15:3; $\mid 1$ Cor 10:1; Phil 2:5-6 and || Cor 8:9-10. Schrage, however, disagrees and says:

What we have said about the life of Jesus [i.e. that it does not provide an ethical paradigm] does not apply in the same way to his message. The significance of Jesus' words is not subject to the same negative verdict as his significance as an earthly person or an ethical model, even though Paul is undeniably much more interested in Jesus' saving work than in his words (Ethics, 209).

7 Hays, "Christology and Ethics in Galatians," 294. Hays cites Furnish among others who oppose Davies and Dodd (See Theology and Ethics in Paul, 264-65.) The most important element of understanding the phrase "the law of Christ," however, is determining what Paul means by "law." As Westerholm says "The phrase ["the law of Christ"] is used loosely, by analogy with the Mosaic code, for the way of life fitting for a christian. No specific collection of commands is in view" (Israel's Law and the Church's Faith: Paul and his Recent Interpreters [Grand Rapids: Eerdmans, 1988] 214, n.38). Also see Lyonnet who says that "The law of the spirit is by its very nature radically different from 
towards the middle path on this issue: although he rejects the notion that the historical life of Jesus is paradigmatic for Paul the incarnation and crucifixion do provide a call to conformity. The usual examples (Phil 2:5-11; 11 Cor 8:9; I Cor 11:1; I Thess 1:6; Gal 2:20; Rom 15:1-7) "demonstrate that christ's humbling himself in the incarnation or his self-sacrifice on the cross not only establishes a formal purpose and intention but defines a fundamental orientation of Christian living."76 Hays, however, sees the imitation of Christ as an important motif in Paul's writings, including Galatians.77

That Paul regards Christ as paradigmatic is also the view of De Boer. Of Rom 15:1-3a he says that in the selfdenial of christ and the "foregoing of his claims, rights

the old law: it is no longer a code...but.... a principle of action, a new, interior dynamism" ("Christian Freedom and the Law of the spirit According to st. Paul" in The Christian Lives by the Spirit [New York: Alba House, 1971] 158). Davies, however, sees Gal 6:2 as part of the evidence "that there was a collection of saying of the Lord to which Paul appealed" ("The Moral Teaching of the Early Church" in Jewish and Paul ine Studies, [London: SPCK Press, 1984] 286).

7 Ethics, 208-209. "What is to be 'imitated" is concern for the good of others rather than self as exemplified by christ, who humbled himself 'for us' (cf. [ I Cor] 10:33)." Earlier Schrage says that, "The love manifested in Christ is also the criterion of Christian conduct. Paul can even find a substantial correspondence between the conduct of Christ and the conduct of those who belong to $\mathrm{him}^{\prime \prime}(173)$.

77 The most important verses for Hays are Gal $2: 19 b-20$ which "give clear evidence that Paul understands his own 1 ife as a recapitulation of the life-pattern shown forth in christ" ("Christology and Ethics," 280). 
and pleasures," which was revealed in his suffering and humiliation during $l$ ife and death, "there is the indication of how Christians are to give themselves in seeking the well-being of their neighbours."78 lt is the pattern of Christ's 1 ife that is to be paradigmatic rather than specific actions, words or events. His life was one of obedience to God and service to others, which resulted in ostensible failure but was ultimately vindicated by God. One of the techniques that Paul uses repeatedly to illustrate his calls to serve, as well as other admonitions, is to offer his own behaviour as an example. His invitations to his readers to "become imitators of me" (I Cor $4: 16$; $11: 1$; as well as Phil $3: 17$ and 1 Thess $1: 7$ ) reflect his proclivity to exhibit his confidence in the rightness of his own approach to whatever is at issue. I Cor 11:1 reveals that paul wants the Corinthians to imitate him because he imitates christ. This is especially apparent with regard to suffering wrong and accommodating oneself to the wishes and interests of others in the first epistle to the Corinthians. In I Cor 4:8-13 Paul contrasts his own position with that of the Corinthians who appear to believe

78W.P. De Boer, The Imitation of Paul: An Exegetical Study (Kampen: J.H. Kok, 1962) 62. Also see De Boer, (7580) for a discussion of how the readers of Ephesians are to imitate God (Eph $5: 1$ ) "by being kind to one another, tenderhearted, forgiving one another, as God in Christ forgave you" (4:32). They are also to "walk in love, as christ loved us and gave himself up for us" $(5: 2)$. 
that their membership in the Church has left them "filled," "rich" and "kings" (4:8). While the Corinthians are wise, strong and held in honour, Paul (and Apollos) are fools, weak and held in disrepute (v10). More importantly, "when reviled, we (Paul and Apollos) bless; when persecuted, we endure; when slandered, we try to conciliate; we have become, and are now, as the refuse of the world, the offscouring of al1 things" ( $v \vee 12-13)$. Paul assures the Corinthians that he does not seek to shame them but rather to encourage them to recognize him as their father in christ Jesus and "to become imitators of me" ( $v v 14-16)$. Part of this imitation is to disavow any claims, for the present at least, to "kingship," wisdom, honour and the like, and to become "fools for Christ's sake," suffering reviling, persecution and slander, without seeking vengeance. The similar call in 1 cor 11:1 follows on his discussion of eating sacrificed meat and his insistence:

Whether you eat or drink, or whatever you do,
do all to the glory of God. Give no offence
to Jews or to Greeks or to the church of God,
just as I try to please all men in everything
I do, not seeking my own advantage, but that
of many that they may be saved. Be imitators
of me, as I am of Christ $(10: 31-11: 1)$.
Here paul explicitly states that part of his imitation of Christ is his attempt to "please all men" and not to seek his own advantage. This is how he wishes his Corinthian readers to behave. The fact that they do not has led to the problems and disputes over eating sacrificed food, and to 
litigation. Despite their apparent wisdom and knowledge they have failed to grasp that the essence of the christian life lies in self-giving and service to others. The needs and interests of the other are to be paramount, not one's own prestige, comfort or religious principles. This is demonstrated by $\mathrm{Paul}$ in his insistence that he has "become all things to all men" (1 Cor 9:22).

Paul does not recall specific incidents in Jesus' earthly life that should be exemplary for believers. Rather, he insists that his readers should try to conform to the nature of christ as it was revealed in the general pattern of his life. Morna D. Hooker sees Paul, in his Corinthian correspondence, as calling for a change in "lifestyle" by summoning Christians to become like Christ which necessarily involves a "concern for other people." The Corinthians' problem is that they understand themselves to be simply recipients of grace and have not sought to be like Christ in their own lives. "They think of the interchange between Christ and themselves in terms of simple exchange-he gives, we take--instead of in terms of mutual give and take.... It is not so much a case of giving to christ but giving in Christ--that is, sharing in his giving."7?. We

79"Interchange in Christ and Ethics," 64-65. She also says that Paul "did not consider Christian ethics to be simply a matter of imitating the example of Christ" since Paul knows that the relationship between salvation through christ and appropriate conduct for christians is profound. she notes that "It is only the dogma that the Jesus of 
must keep these words in mind as we turn now to an

examination of Phil 2:5-11.

We have to ask whether Phil 2:5-11 actually calls

Christians to imitate christ. Several scholars, such as

Dihle, believe that there is no doubt that the text in

question calls Christians to imitate christ in his humility

and self-sacrifice and thereby constitutes a call to fulfill

the servant-ethic.80 Those who oppose this understanding

History and the Christ of Faith belong in separate compartments that leads to the belief that the appeal to a christian character appropriate to those who are in Christ is not linked to the pattern as seen in Jesus himself" (Hooker, "Philippians 2.6-11" From Adam to Christ: Essays on Paul [Cambridge: Cambridge University Press, 1990] 9091. Hooker acknowledges that paul does not often explicitly call Christians to imitate Christ. She points out, however, that in 11 Cor $8: 9$ a summary of the Gospel message similar to Phil 2:6-11 is made and that its context also concerns Christian behaviour (Ibid., 91). Harvey suggests that the lack of calls to imitate the specific content of Christ's ethical conduct in Paul and other New Testament epistles can be explained by the slant put on the life of Jesus by the earliest Christian interpretations of his death and resurrection: "We might say, the inspiration for our loving is not the moral example afforded by Jesus in his 1 ife, but the theological imperative implied by $h$ is death" (Strenuous Commands, 180). Thus Harvey sees the meaning of Jesus' death as overwhelming the ethical content of Jesus' life from the very first so that it became the basis for arguing (or explaining) matters both theological and ethical.

BOA. Dihle, "Demut" (RAC 111 [Stuttgart: Hiersemann, 1950]) 749. Hooker also acknowledges this aspect of the passage by pointing out that paul does not introduce the hymn with the phrase en Christoi but rather with en Christo i lesou. She sees particular significance in this: "The life which should be demonstrated in the lives of those who are en christöi, which is possible only because of the salvation events, is precisely the kind of life seen in Jesus Christ" ("Philippians 2:6-11," 154). Also see webster, "Christology, Imitability and Ethics," 320. 
of the passage claim that it makes $v v 9-11$ of the Christological hymn irrelevant.81

While the debate over the correct interpretation of vv5-11 is intense, it is clear that Paul called the Philippians to humility because of their relationship to christ. To my mind, christ plays a paradigmatic role in this passage. His self-humbling and "taking the form of a slave" serves as an example of the humility the Philippian Christians should practice.

Paul formulates $h$ is appeal to the Philippians for humility and the subordination of one's own interests to those of others in these terms: touto phroneite en hymin ho kai en christōi lesou. Upon this verse turns much of the interpretation of $2: 1-11$. It is the connecting link which determines how the Christological hymn is to be interpreted in light of verses 1-4. Beare translates this verse, "Let this be the disposition that governs in your common life, as is fitting in Christ Jesus." 2 Beare says:

- 1 Using Käsemann's argument Ralph P. Martin, for example, attempts to show that the ethical interpretation of the hymn renders vv9-11 irrelevant because they are not explicitly paranetic. These verses do not precisely state that the Church will share in Christ's exaltation "however well-attested elsewhere this idea may be" (Carmen Christi [Cambridge: Cambridge University Press, 1967] 88).

82 A Commentary on the Epistle to the Philippians (London: Adam and Charles Black, 1959), 73. Also see Bornkamm, who says:

"Have this mind" does not refer to a

"disposition" oriented toward the ideal of a 
Their [the Philippian Christians'] mutual

relations within the Christian community are

to be analogous with the relations of the christian with christ. The whole atmosphere and attitude of 1 ife in the Christian community must always be that which befits those who are in Christ Jesus; and that is the likemindedness, the unity of soul, the humility, the mutual esteem and mutual concern which has been enjoined in verses $2-4.63$

The verb phroneo links verses 2 and 5 so that the disposition (to use Beare's word) that exists amongst Christians is founded upon the truth of Jesus Christ's own experience. What was that experience? It was a surrendering, an emptying; it was the act of becoming a slave (vv6-7). Stephen E. Fow l, therefore, understands the hymn to have the function of presenting christ as an exemplar.84 He does not explicitly connect Christ taking the form of a doulos with this observation, however:

In emptying himself and taking on the appearance of a servant, Christ moved from a position of equality with God to one of obedience to the will of another. This phrase, however, is somewhat ambiguous in that it does not specify to whom and to what christ

virtue. Rather it means a "directing oneself toward," a "self-orientation" toward a given and fulfilled reality that is determined and opened "in Christ Jesus" ("which is also in christ Jesus"). With concerted power our text directs all the thinking of believers to this ("On Understanding the Christ-Hymn" Early Christian Experience [New York: Harper and Row, 1969] 112 .

${ }^{3}$ Philippians, 76, emphas is his.

- The story of Christ in the Ethics of Paul (Sheffield: sheffield Academic Press, 1990) 92-95. 
appeared as a servant. Was Christ's appearance as a servant manifested in taking on a human body or in being seen to be obedient to God? By not explicitly resolving this ambiguity the passage is able to draw on both possibilities.o5

A third ambiguity can be added: Christ's "appearance" as a slave/servant is manifested in his willingness to look to the interests of others--his undeterred readiness to serve and to love. This, perhaps is the form of slavery that paul

B S The story of Christ, 59. Bornkamm sees Christ's taking the form of a slave as directly related to $h$ is becoming incarnate and suffering human bondage to world powers ("On Understanding the Christ-Hymn,"115-116). C.A. Wanamaker also understands the enslavement to be directly related to becoming human--it is the consequent enslavement to sin and death ("Philippians 2:6-11: Son of God or Adamic Christology?" NTS 33 [1987] 189. L.W. Hurtado comes to similar conclusions to Fowl although he prefers to read doulos as describing Christ's relationship to God: "While it is not expressly stated in 2:7 that Jesus was doulos to God, neither is it expressly stated that Christ became doulos to evil powers... and there are better reasons for taking the former meaning than the latter." He offers three just ifications for his interpretation:

i) He notes that in Paul doulos and its cognates are used most often to refer to Christian life and service "and is never used to mean human existence as such."

ii) In the immediate context the contrast between the haragmos which is put aside and the taking the form of a slave "suggests that what is meant is service toward God, or for his sake."

iii)Hurtado thinks that the most crucial reason for the correctness of $h$ is interpretation is "the striking dio of $2: 9$, and the fact that God is the actor in 2:9-11, show that the service of $2: 7-8$ must be seen as offered to God, and that 2:9-11 is the divine response." Paul therefore "makes God's act of exaltation a consequence of Christ's obedience" rather than simply contrasting the acts of God and Christ ("Jesus as Lordly Example in Philippians 2:5-11" From Jesus to Paul [Water 10o, Canada: Wilfrid Laurior Press, 1984] 122-23). Hurtado also makes the point that the doulos wordgroup often refers to general Christian 1 ife in Paul whereas diakonos and cognates more often refers to church service (ibid., 122, n.36). 
wants to convey Christ as taking: not only standing in obedience rather than equality with God, nor simply becoming human and thereby somehow enslaved, but unreservedly taking on the role of a servant of others and confirming the principle Jesus himself speaks of in Mark 10:45. On this reading of the passage the disposition or likemindedness spoken of in verses 2 and 5 is ultimately a readiness to serve--a state of mind that is found in Christ and in believers to stand ready to serve the interests of others whatever the cost. Where does this leave the remainder of the hymn? For christ such a disposition led ultimately to death, "even death on a cross," an ignoble, dishonourable death. But God, of course, was faithful so that Jesus Christ was ultimately exalted. The passage implies, but does not specifically state, that christians have the same hope.

Thus the Philippians' humility and willingness to serve the interests of others have a direct bearing on their relationship to Christ. Like Mark 10:45 the role and person of Jesus Christ gives shape to the call to servanthood and humility: "Whatever else it may be, Christ's action is more than vicarious: it is evocative, it constitutes a summons to a properly derivative mimesis." 6 But we can go beyond

86 Webster, 321. Jo-Ann Martens understands the concept of "mimesis" in Paul as found in I Thess 1:5-6, 2:14; II Thess 3:6-9, I Cor 4:16-17, 10:32-11:1; Phil $3: 17$ and Eph $4: 31-5: 2$ as a means to realize "the ethical principle that 
the idea of mimesis here and claim that the point of the passage is to emphasize to the Philippians that their new life in christ gives rise to this. As Hooker says, "It would be better, perhaps, to use... 'conformity'...when speaking of the appeal paul makes in 2.5-11... One cannot separate the Christian character from the character of Christ himself."B

As we have noted the main drawback to this interpretation put forward by those who oppose any attempt to claim the hymn as illustrative of some ethical interpretation is that it tends to render the second half of the hymn to christ irrelevant. At the end of his discussion on this issue, Martin offers what he considers to be the most compelling piece of evidence against the theory that

one should subordinate personal interests and privileges to the good of the community" ("Pauline Mimesis: The Realization of an Ethic" [M.A. thesis, McMaster University, 1986] 4). She says further:

Mimes is is a process in which the imitator expresses the essence of an idea in concrete form. For Paul, this form is conduct. In all cases, the standard to which these communities mimesis conforms is the ethic that one should subordinate $h$ is or her rights to the interests of others (ibid., 21).

87"Philippians 2.6-11,"92. Harvey confirms this reading. He says that Philippians 2 "is an 'example" only in the sense that divine action in Christ becoming man can inspire acts of human self-abandonment and generosity" (strenuous Commands, 181). ( $\mathrm{H}$ is use of the adverb "only" is somewhat puzzling since the divine action is astonishing and its consequences, self-abandonment and generosity, profound.) 
the hymn offers Christ as an example. We learn that Martin is, above all, squeamish about the idea of reward. He says: "In fact the teaching of 'reward' is a positive hindrance to disinterested ethical endeavour."Bs so, rather than an objective view of the text, in the context of pauline and New Testament teaching as a whole, we see that what worries Martin about the ethical interpretation of the christological hymn is that it might remind christians that a heavenly reward awaits them if they seok to be humble as Christ was. Martin prefers to believe that Christians in Philippi pursued the good for its own sake and had no thought about the personal consequences of such a quest.89 At the same time, however, we should note that both Paul and the four gospels do not primarily depend upon the promise of heavenly reward as a motivating factor for appropriate conduct, but upon the experience of God's grace as already manifested in the life and death of Jesus. It is only because of this experience that Christian moral injunctions have any foundation or appeal. Reminders of Christ's exaltation following his humiliation and enslavement do not seek to make Christians humble and selfeffacing by promising a heavenly reward; it is assumed that

\section{B B Carmen Christi, 88.}

Ooihle, also, is perhaps overly apprehensive in $h$ is concern that humility not be cultivated with a view to receiving some kind of divine blessing ("Demut," 751). 
believers already seek to serve others based on their experience of christ. The various claims that exaltation does indeed await them are promises not bribes.

Christian Wolff summarizes Paul's attitude to the role of Christ as exemplar in his own life. He points to I Cor $10: 33$ and even 11 cor $4: 5$ (see below) as instances in which Paul deliberately invokes Jesus' example as the motive for his own conduct: "In the service of this Kyrios, who brought about salvation through lowliness, the apostle works selflessly for the church."go salvation has come through selflessness. The self-denial and service of Jesus therefore becomes paradigmatic for the attitude of believers toward others.

Serving others for the sake of the gospel

There are two passages in the corinthian correspondence in which paul speaks of serving others for the sake of the gospel or of Jesus $(1$ Cor 9:19; 11 Cor 4:5). These verses refer to Paul's commitment to the spread of the gospel and his desire to bring others into the community of believers. To do this he is willing to serve others and become like a slave to them ("For what we preach is not ourselves, but Jesus Christ as Lord, with ourselves as your servants [or slaves] for Jesus' sake.").

90 "Humility and Self-Denial in Jesus' Life and Message and in the Apostolic Existence of Paul" Paul and Jesus

(Sheffield: JSOT, 1989) 155-56. 
The Limitations of the Pauline servant-Ethic

It is as difficult in Paul as in the synoptic texts to find limits to the servant-ethic. If we look to the example of Paul himself we can see that he placed no explicit limits on his role of servant to others while carrying out his apostolic responsibilities and even set aside his rights as an apostle for the sake of the gospel (e.g. I Cor 9:1-18). Paul's limitations upon the servantethic are, like the synoptic writers', implied rather than baldly stated. There are no limits to the lengths a Christian should go to serve others unless he or she $r$ isks violating the will of God. If serving others by surrendering one's rights and conceding to the requirements of others does not violate God's will it constitutes service to God and should be undertaken.

As in the synoptic texts, questions of prudence and justice as they relate to the interests of the self are not a primary consideration. Prudence is perhaps required in discerning the will of God, but only to the extent that acts of service be in accord with it. Justice, in the sense of vindicating one's rights, ideally is to be set aside (1 cor 6:7). The main problem for Paul is not discovering the 1 imits of the servant-ethic but encouraging his readers to implement it fully in their lives: the divisions and squabbles within the congregations are evidence that believers are not serving the interests of others but are 
still seoking self-aggrandizement. Rather than looking to Christ and his example of self-denial and humble service, they are trying to assert their own interests, whether out of simple misunderstanding or wilfull disobedience. Many of Paul's readers are not yet free to serve.

Conclusions: Freedom in Christ and serving others

Allen Verhey identifies freedom (informed by love) as the most fundamental value for Paul's discernment in matters pertaining to God's will.91 Nevertheless, Paul warns the Galatians not to use the freedom to which they have been called as "an opportunity for the flesh." Rather they are to become as slaves to one another through love (Gal 5:13). Barrett understands love to be the opposite of flesh and "Flesh...means self-centred existence, egocentric existence; not specifically a proclivity to carnal sins (as we call them), but a concern focused upon oneself."92 The freedom to which Christians have been called is the freedom from self demonstrated in the crucifixion of christ on behalf of others. This awareness has a profound impact on Paul's ethical view because it is the basis for all his thought:

The very existence of Christian ethics is a paradox; the paradox is nowhere sharper than it is with Paul, and nowhere sharper in Paul

'The Great Reversal, 107-8.

2 Freedom and Obligation: A study of the Epistle to the Galatians (London: SPCK, 1985) 73. 
than in Galatians. We must remind ourselves of this; it is impossible to underline it too heavily. For Paul, everything turns upon the free action of God in grace; and there is no exception to this "everything." 3

For Paul freedom in Christ and the love of Christ become the final arbiters in resolving moral dilemmas. Love and freedom together recognize the flux and change of the human situation.94 Freedom recognizes the vast number of courses of action that may be taken by one justified by faith in Christ, while love identifies the potential consequences for others. If harm to another results from a specific act then the christian who performs that act is not free in christ. The tyranny of the self has triumphed over

23 Freedom and Obligation, 53.

4Paul Tillich aptly summarizes this viewpoint:

Love, as the ultimate principle of morality, is always the same. Love entering the unique situation, in the power of the spirit, is always different. Therefore love liberates us from the bondage to absolute ethical traditions, to conventional morals, and to authorities that claim to know the right decision perhaps without having listened to the demand of the unique moment... . Love can reject as well as utilize every moral tradition, and it always scrutinizes the validity of a moral convention (Morality and Beyond [New York: Harper and Row, 1963] 43). 
the pursuit of God's wil1.95 It is faith in God's saving mercy which makes this freedom from self possible:

Faith is an openness to God so complete that it can never be combined with the closing of the believer's heart against $h$ is fellow....Faith is more than obedience; it is a confident trust, in which man gives himself up to the one who loved him and gave himself for him. He no longer has any occasion to be concerned about himself, his life in this world or his life in the world to come. So far as he believes he has forgotten himself; and this is a negative definition of love. Thus even obligation becomes an aspect of freedom. The freedom of $f$ aith demands and makes possible the obligation of love.96

Based on these observations we might suggest that

Enslin misses the mark when he says,"Paul, though free, was ready to sacrifice his freedom to the claims of brotherhood; so must the other Christians. Christianity consummated the ethics of self-realization by the ethics of selfsacrifice."gr Paul never suggests that one sacrificed one's freedom in Christ by responding to the claims of brotherhood. Temporal rights and privileges may be surrendered but these are not the stuff of self-realization or of christian freedom. Freedom without service is merely

95 Cf Longenecker, Paul: Apostle of Liberty, 202-208 and $h$ is discussion of "love as the conditioning factor in the exercise of Christian liberty" (202). At the risk of introducing a dispute merely concerned with semantics 1 do not see love as conditioning or limiting freedom in Christ but necessarily working in concert with it.

- Barrett, Freedom and Obligation, 67.

97 The Ethics of Paul, 243. 
the tyranny of the self and cannot be christian. Service without love born of Christian freedom risks becoming redundant and irrelevant ( 1 Cor 13:3). The willingness to serve others reflects the truth of self-realization in Christ: the paradox of Christian selflessness.

This paradox is reflected in Paul's own experience and self-understanding. He "boasted in his infirmities" and clearly saw himself as an exemplar of self-denial. Nevertheless, he asserted his apostolic authority whenever necessary and also understood this as part of his service to others for the sake of the gospel. Thus the undercurrent of arrogance and even authoritarianism in his writings is overcome by $h$ is endorsement of the principles of selflessness and "other-directedness" which he sees as essential to authentic Christian existence. This is most apparent in his writings to the Galatians and the Corinthians, less so in Romans, which is directed to a community with whom he had no personal contact. Despite this ambivalence, we discern in Paul a genuine concern to place the interests of others first, often at significant personal cost to himself. There is no hint that he strives after selfish gain even in the defence of his apostolic authority. The dilemma of Paul is to practice self-denial, 
and at the same time encourage it in others.98 He strives to maintain both his authoritative position within the community and his role as a servant of the gospel and of others. His epistles clearly illustrate the importance of the servant-ethic as characteristic of the early Christians' self-understanding.

98 Outka perhaps captures the essence of Paul in this regard when he says:

For many, to live the agapeistic way of life is to go the second mile in respect to supererogation as well as the first mile in respect to duties. And two things should be especially noticed here. First the agent need not apply the distinction to his own actions. Indeed he has authority for saying that he should regard himself as an unprofitable servant after going the second mile as well as the first. And he may find references to "stringency" or "higher duty" ill-suited to convey his devotion to the other for the other's own sake. He may also sense that he is led to such actions by grace and not by his own resolve; his operations may appear spontaneous and joyous..... While he may exhort others to go the second mile, he cannot reproach them for not attempting it as he can when they do not go the first. This is a point at which agape is genuinely radical so far as the agent is concerned..... For if the essence of any ideal involves expressing one's own vision of human excellence, to realize the agapeistic ideal one must be the sort of person who furthers the interests of others. A man may be intelligibly harder on himself than on his neighbors when in so doing he positively contributes to their welfare (Agape: An Ethical Analysis, 294-295).

Paul as champion of the "agapeistic ideal" has no qualms about going the second mile to further the interests of others. 
When one becomes "free in christ" therefore, the event is demonstrated by the transformation of an individual from egocentric to "other-directed." One's own interests are subordinated to the interests of others who are to be served in love. One practical consequence of this transformation is that one is relieved of the tedious task of judging others and of deciding who is worthy. To behave as a doulos reveals that one has placed oneself in God's hands and is totally reliant upon him.9o it is for him, and him alone, to decide who deserves honour. Christians are called to serve through their love and freedom in Christ. As Pheme Perkins points out, the problem for Paul, and Christians in general, is determining how to walk according to the spirit in specific situations. The freedom Christians have achieved in Christ, according to Paul, liberates them for service on behalf of others. While there are no rules of conduct that can be applied in every situation, the principle that the interests of others rather than of the self are to be paramount guides every ethical decision. Freedom in christ is liberation from self and results in selflessness.

9 Humility as a mark of the elect underlies many of the texts we have considered. It is explicit in Gal 5:13; Eph $4: 1-3$; Col $1: 25,3: 12$, but all of the texts which promise a reward or exaltation for the humble may also be considered in this category. 


\section{THE SERVANT-ETHIC IN OTHER NEW TESTAMENT WRITINGS}

The servant-ethic points to a strong ethical link between the synoptic gospels, the Johannine writings, and the undisputed Pauline epistles. We shall now turn to the remainder of the New Testament to see if the chain is as secure in those texts, and if it is not, what elements of the servant-ethic, if any, are evident.

\section{The servant-Ethic in Acts}

As we have noted above, the servant-ethic proceeds from a radical transformation of the heart, a metanoia. In Acts there are two passages which illustrate both the success and failure of such a transformation and the consequences in terms of the servant-ethic. The first passage is found in Acts 8:9-24 and describes simon Magus. conversion and subsequent encounter with Peter. This passage is important for two reasons: it illustrates how submitting to the wishes of others must never contradict the will of God, and also how God does not require money and possessions but the heart and will of an individual.

with regard to the first of these points, simon's request to receive the power to bestow the Holy spirit is bluntly rebuffed by Peter. Peter understands the limits of 
his ability to serve simon. Even to suggest that it is possible for simon to receive such power in return for money would constitute disobedience to God. The fact that simon believes such exousia can be bought leads to the second point. Peter admonishes simon to repent so that he might be forgiven. Simon has not yet learnt what it truly means to repent and therefore what it means to be a Christian. He has been too dazzled by apostolic power, and the desire to have it for himself, to be able to come to an understanding that his own self must be abandoned to God. His ambition and self-will have not been surrendered. He seeks to be served rather than to serve. Peter's words "Your silver perish with you" reminds the reader that it is folly to think that money and possessions have real value in the context of God's kingdom (See Matt 6:19-21; Mark 10:21; Luke 12:33-34; Jas $5: 1-3 ;, \operatorname{Tim} 6: 17-19):$

As Simon's intention was expressed by his use of money, so is $h$ is peril....simon has expressed by his use of money his selfaggrandizing drive, his desire to secure his "self"; the money can also express the loss of his "self" as it joins him in perdition.'

Despite his apparent belief and baptism, simon has yet to yield absolutely to God. And it is there that Luke leaves the reader. The story of simon recalls the episode about the ruler in Luke 18:18-25. While the ruler could not

1 Luke T. Johnson, The Literary Function of Possessions in Luke-Acts, 216. 
abandon his material wealth for the sake of eternal 1 ife, Simon believes that the $r$ iches of the Kingdom can be bought with his money. Possessions and the hunger for status have overpowered both individuals, making it almost impossible for them to yield to the will of God.2

The second passage is found in Acts 16:25-34 and describes the conversion of Paul and silas' jailer. The response of the jailer to the pair's refusal to escape $h$ is custody following the earthquake is a prime example of how the transformation of one's heart following repentance makes the servant-ethic integral to the Christian life. The jailer's conversion is a six step process of inquiry ( $v .30)$, hearing the gospel ( $v v$ 31-32), service (he washed their wounds, v.33), acceptance (he was baptized, v.33), service (he brought them up to his house and set food before them, $\checkmark .34)$ and rejoicing $(v .34)$. This is the clearest instance in Acts of how an affirmative reaction to the gospel brings about an ethical response in turn. While it is certainly possible that the jailer could have been moved by gratitude and compassion to wash and feed Paul and silas, it is

2 The reader never learns whether either man finally acquiesces. The fact that Peter does not respond to simon's request for prayer reflects, according to Conzelmann, Luke's uneasiness about the situation: "Luke does not report Simon's apostasy, nor could he make the well-known rival into a Christian" (Acts [Philadelphia: Fortress, 1983] 66). A more graphic depiction of the failure to surrender is in the passage describing the fate of Annanias and Sapphira, who seek to withhold their material wealth from the community and pay dearly for their deception (Acts 5:1-11). 
important that in this passage such service is intimately linked with his conversion. His baptism is bracketed by his acts of service to the two prisoners.3

Such service to others is highlighted by the sharing of goods practised by Christians in Acts $2: 43-45$ and $4: 32-$ 37. Here, those who are in need benefit as the wealthier believers relinquish property and goods to be distributed by the apost1es.

In Acts, the gospel spreads outwards from Jerusalem to capture the hearts of the Gentiles and the world. It is this story that Luke recounts and, therefore, explicit ethical instruction is sparse.4 Nevertheless hints of the servant-ethic are discernable that go beyond the Hebrews' willingness to make arrangements for the Hellenist widows to be included in the daily food distribution.s

3 The jailer's behaviour is similar to that of Lydia in Acts $16: 15$ who invites Paul and his company to stay at her home following her baptism.

4he statement that "It is more blessed to give than to receive" in Paul's speech to Christians at Miletus is one notable exception (Acts 20:35).

3 This is an interesting incident because the apostles' show a certain unwillingness to perform the more mundane tasks of service within the community. Thus seven are appointed. to take responsibility for the disposition of community goods. Luke $T$. Johnson points out that once their selection is complete we hear no more of them performing such tasks--they too, like the Twelve, become "ministers of the Word." Johnson explains this discrepancy:

He [Luke] wants to express a bestowal of authority on hellenistic missionaries.... The primary symbol for expressing the authority of 
The Servant-Ethic in Colossians

The authorship of the epistle to the Colossians is disputed by many (e.g. Eduard Schweizer), 6 and accepted unreservedly by others (e.g. C.F.D. Moule).T The vocabulary, style and theology of Colossians differs from that of the Pauline epistles discussed above, but it is not inconceivable that Paul is indeed the author; early Christians certainly believed this to be the case.8

In col 1:24-29, Paul describes how his suffering is on behalf of the Colossian Christians and reflects his role as a servant (diakonos) of the church.' More remarkably,

the Twelve over the people has been their place over the community of goods. He therefore expresses the bestowal of spiritual authority on the seven by having them placed over the disposition of goods. What luke is really talking about is the transferral of power. The symbol he uses is power over possessions. It is awkward; once the image is established, he forgets it and talks about the reality of spiritual power (213).

6 The Letter to the Colossians (Minneapolis: Augsburg, 1982).

7 The Epistles of Paul the Apostle to the Colossians and to Philemon. (Cambridge: Cambridge University Press, 1968).

8 Fortunately we do not need to establish the authenticity of the epistle to see if the servant-ethic figures in its ethical content. For the sake of convenience, however, we shall refer to the author as Paul.

- Schweizer finds in these verses evidence that Paul is not the author of Colossians since the passage "exceeds" what Paul says of himself in Rom 15:15-21 and I Cor 2:6-16 concerning his role as apostle (The Letter to the Colossians, 100). 
Paul characterizes his suffering as completing "what is lacking in Christ's afflictions" (1:24). F.F. Bruce explicitly relates this verse with the portrayal of the suffering Servant in Isaiah, who, in the "history of interpretation" first represents corporate Israel, then the individual Jesus Christ, and then the body of the church. "The servant's sufferings are...to be carried on by the disciples of Christ--at least by one of them, Paul himself."10 For Bruce, the suffering of Paul (and any other Christian) insofar as he is part of one body, the Church, of which Christ is the head, means that Christ himself suffers. "And as Christ Himself suffers in His members, this suffering of theirs may be regarded as a filling up of Christ's personal suffering."11

Bruce also draws attention to another possible interpretation which, if it can be maintained, is more pertinent to our study. He points out that Paul might be suggesting that his own suffering fulfills more of the quota of hardship to be endured so that his fellow Christians in Colossae will not have to endure so much.12 Paul

$10 \mathrm{~F} . F$. Bruce and E.K. Simpson, A Commentary on the Epistles to the Ephesians and the Colossians (Grand Rapids: Eerdmans, 1957) 215-16.

11 Bruce, Ephesians and Colossians, 216.

12 Bruce, Ephesians and Colossians, 216-17. This idea is taken up by Moule, who understands such an interpretation to be the dominant one, although both this and the idea that Christ suffers in his members suffering are pertinent 
understands his sufferings to be for the sake of his fellow Christians, the church, the body of Christ. He has become a diakonos of the church $(v .25)$, so as "to make the word of God fully known." Schweizer believes Paul's designation of himself as diakonos of the church tells against the authenticity of the epistle.13 Paul, however, as we have seen above, is very conscious of the role of Christians as diakonoi and douloi, and it may be that the use of the word office (oikonomia) has led schweizer to understand diakonos as an ecclesiastical position, rather than a description of Paul's role as he serves his fellows in his suffering. Paul's "office" is not diakonos but to "make the word of God fully known." He undertakes this office as a servant of the church.14 Paul makes sense of his sufferings in prison by seeing them as part of his service to his fellowChristians.

(Colossians and Philemon, 76-78). Moule believes that "Paul and his contemporaries were familiar with this way of looking at things: a definite quantity, known to God, if hidden from men, of sins, sufferings and conversions must precede the End" (78). Schweizer, on the other hand, rejects this interpretation: "The idea of a precisely predetermined measure of such sufferings is scarcely present here" (Colossians, 105).

13 Colossians, $106-107$.

14 Schweizer never explicitly says that col 1:25 implies that Paul's "office" is to be a "minister" (diakonos) but $h$ is commentary on $v .25$ certainly implies such an understanding. See Moule, Colossians and Philemon, 80. Moule is very clear in understanding Paul's office or task assigned by God to be that of "fully proclaiming God's message." 
Paul describes the service his readers should render others in col 3:12-15. They are to be compassionate, $k$ ind, humble, meek, patient and forgiving. Above all they are to love one another in order to preserve harmony. The Colossian Christians are to put off the old nature $(3: 10)$ and put on that which is fitting for God's elect.

Much of the epistle to the Colossians involves polemic against what Meeks terms a "deviant form of Christianity."1s Consequently, much of the epistle is concerned with encouraging its readers to close ranks against heretical tendencies and to maintain a unified community. Colossians also illustrates the idea of freedom from old ways of thinking about religious principles and ideas $(\operatorname{Col} 2: 20-23)$. This pursuit of unity and the transforming liberation in Christ are illustrated in the two different uses of the word tapeinophrosyne (humility), which in $2: 18$ and 23 refers to heretics and in $3: 12$ to Christians.16 We shall examine this more closely, because most commentators agree that in the first two instances the word is a technical term.

13 The Writings of Saint Paul (New York: w.w. Norton and Co. 1972), 113 .

16 See K. Thieme, Die christliche Demut (Giezen: Alfred Topelmann, 1906) 19. Thieme claims Philippians was written after Colossians and Ephesians so that the word tapeinophrosyne came to Paul through the heretics in Colossae (!) 
In his article on "Humility and Angelic Worship in

Col 2:18," Fred 0 . Francis points out that most scholars and commentators are satisfied with suggesting that the tapeinophrosyne of $2: 18,23$ cannot be the same as that in $3: 12$ and the reference in the first two verses is to false humility.11 Francis concludes that in $2: 18,23$ the word is a technical term of the writer's opponents and offers much evidence from various texts, primarily Hermas and Tertullian, where the word is used for ascetic devotion. He also points to other texts where fasting is accompanied by divine visions.18 The main problem with this evidence is that it tends to be late, much later than any would date colossians. That does not of course mean that the term is not technical in $2: 18,23$. We have to consider, however, its relationship with the same term in 3:12, where we assume it is used in the everyday sense. The possibility remains that the word means the same thing in all three verses; that is, general self-abasement, but that the distinguishing feature of $3: 12$ is the readers' status as eklektoi tou theou. The tapeinophrosyne of $2: 18$ and 23 is of no avail because it is not done with reference to the

17 In Francis and Meeks, Conflict at Colossae (Cambridge, Massachussetts: Scholars Press, 1975). See also, for example, Ralph P. Martin, Colossians: The Church's Lord and the Christian's Liberty (Exeter, Devon: Paternoster, 1972) 121.

18 "Humility and Angelic Worship," 167-171. 
kephalè, to Christ, and is, therefore, self-indulgent $(2: 23 b) .19$

In 3:12 the word is used in a list of things a Christian is to "put on." The context reveals both the need for mutual service within the community, and for forgiveness toward others "as the Lord has forgiven you" ( $v .13)$. The relationship between the readers and God and Christ points the way. To be holy and elect one must be humble, compassionate, meek and kind to others, especially fellowchristians. Toward outsiders Christians should conduct themselves "wisely," although there is no direct admonition to love or serve them. The important thing is to maintain unity within the church, especially in the face of heretical opposition.

The Servant-Ethic in Ephesians

In Ephesians concerns about unity in the community are also paramount and again readers are exhorted to display appropriate behaviour towards each other.

Eph $4: 1-3$ reads:

I therefore, a prisoner for the Lord, beg you to lead a life worthy of the calling to which you have been called, with all lowliness

(tapeinophrosyne), and meekness, with

19 The correct translation of the last part of $2: 23$ is difficult to determine. The RSV offers two alternatives: "But they are of no value in checking the indulgence of the flesh" or "they are of no value, serving only to indulge the flesh." 
patience, forbearing one another in love, eager to maintain the unity of the spirit in the bond of peace.

It is almost certain that the author of Ephesians has used Col 3:12-15 as a basis for these verses.20 As Wengst says, these verses encourage ecumenical unity by admonishing Christians to strive after harmony within the community. 21 By "forbearing one another in love" they practice the servant-ethic by "putting up with" each other. The use of the verb anechō has connotations of endurance. The Ephesian Christians are to tolerate each other rather than seeking to rebuff or repudiate others. The construction in Ephesians also recalls the inversion of the traditional order that the gospel brings about. To be worthy of one's election one must be lowly. The context of the verse not only encourages unity but also reminds readers of the work of Christ.

Eph 5:21 also reminds readers of Christ when the writer tells them to submit to one another. This verse directly precedes the Ephesian Haustafel, a block of traditional paranesis that serves primarily in Ephesians to illustrate the relationship between Christ and the church (23-33). Thus, after the author tells readers to submit to one another "out of reverence for Christ," he seeks to

20 For a full discussion of Ephesians' dependence upon Colossians, see C.L. Mitton, The Epistle to the Ephesians (London: Oliphants, 1962) 55-74.

21 Humility, 53. 
remind them that Christ gave himself up for the church

(v.25). While Christ is the kephale, he is also the one

who gave himself up for the sake of the Church.22

Christians, therefore, are called to mutual submission out

of reverence for Christ, because they should demonstrate the

love that could lead to self-sacrifice on behalf of others.

Thus the placement of $v .21$ immediately before the expanded

Haustafel links it with the comparison between marriage and

Christ and the Church.

22 The passage concerning marriage differentiates the Ephesian Haustafel most clearly from those found in

Colossians and I Peter. As Verhey summarizes:

Clearly both husband and wife are under

Christ--and equally under Christ. The opening

instruction to "be subject to one another out

of reverence for Christ" should make that

clear. The analogy does not intend to say the husband is the "Lord" or "Savior" of the wife.

It points instead to the husband's service and

love... The author of Ephesians does not

disown the traditional authority of the

husband, but he transforms it by this analogy

to Christ's authority over his church. The

authority of the husband is not what is being

taught here; that is assumed in the

conventional role assignments of the times.

But that authority is put into the context of

mutual subjection, reciprocal obligations,

loyalty to Christ, and the fundamental

obligation to love the neighbor, including and

especially the neighbor who is one's wife

(Verhey, The Great Reversal, 126).

Fiorenza aptly notes that "One could say that the exhortations to the husbands [in the Ephesian Haustafel] spell out what it means to live a marriage relationship as a Christian, while those to the wives insist on the proper social behavior of women" (In Memory of Her [New York: Crossroad, 1984] 270). 
Eph 4:32-5:2 perhaps echoes the servant-ethic most clearly. Here the readers are called to mutual kindness, imitating God in his forgiveness and remembering the love that Christ displayed in his sacrifice on their behalf. It is this element of self-sacrifice that is most pertinent to our theme and it is notable that in Ephesians it also occurs in a discussion of household relationships and calls the dominant partner to be willing to practice self-sacrifice on behalf of the other $(5: 25-28) .23$

The Servant-Ethic in the Pastoral Epist les

In the Pastoral epistles little is said of serving the interests of others. Moral and ethical concerns are addressed generally using exhortations which are considered normative and are to be applied universally.24 The ethics described is primarily one of individual godliness and much is made of the moral qualifications of those seeking ecclesiastical office (I Tim 3:1-13; 5:9-22; Tit 1:7-9). Interestingly, little is made of these officers' responsibilities to serve the interests of others, although

23 it would be dangerous to push the analogy too far here. It seems that the author is more interested, based on the overall thrust of the letter, in explaining Christ's relationship to the church than in sketching the ideal marriage.

24 Verhey is more blunt in $h$ is assessment: "The spirit of the ethic here is indisputably more pedestrian and prosaic... The gospel gradually has become identified with "sound doctrine" (The Great Reversal, 126). 
widows who seek to be enrolled should have performed "good deeds"--demonstrated, in part, by their hospitality and the act of washing the feet of the saints (1 Tim 5:10). As Furnish points out, the nature of Christian love is somewhat diminished in these letters and that love appears most frequently in lists of virtues: "In these lists "love" invariably stands as simply one among several desirable characteristics of the Christian 1 ife."25 Quarrelsomeness and anger are forbidden, nevertheless, but more on the grounds that such behaviour is unseemly and inappropriate than out of genuine concern and empathy for one's fellows ( 1 $\operatorname{Tim} 2: 8 ; 3: 3 ;$ Tit $3: 2-3)$.

Nevertheless, as Barrett says, "truly Christian motives do underlie the ethical teaching of the Pastorals, though it must be admitted that these are sometimes far from evident."26 The pastoral epistles reflect some traces of the servant-ethic. Much is made, for example, of the responsibility of the community for the poor, especially widows. As far as possible families are to care for their own but the church can be called upon to provide for widows. Schrage deplores the fact that moral judgment is involved in this process and it is true that certain conditions are

25 The Love Command, 127-128.

26 The Pastoral Epistles (Oxford: Clarendon, 1963) 26. Barrett continues: "It is God himself who commands the Good Life." 
applied in 1 Tim 5:3-16 to distinguish those who will

receive benefits from the church and those who shall not:

There are moral as well as social criteria for

those supported by the community.... The

charitable work of the community is thus

contingent upon both social and moral

conditions.... The difficulty is that moral

criteria are now being used to judge people's

behaviour. 27

1 Timothy also cautions against making too much of

personal wealth. The wealthy are to be "rich in good deeds,

liberal and generous" mindful that true riches come from God

(6:17-19). Likewise, the epistle to Titus concludes with

the exhortation to "do good deeds so as to help cases of

urgent need" ( $3: 14) .28$ While the pastorals do not reflect

the servant-ethic as clearly as we would perhaps expect,

27 Ethics, 266-67.

28 There are difficulties with interpreting the meaning of the areek in this verse. The verse can also be understood to read: "Enter honourable occupations so as to satisfy necessary needs"; i.e., "Get a good job so as to put food on the table." See Barrett, Pastoral Epistles, 148; Hanson, Pastoral Epistles (Grand Rapids: Eerdmans, 1982) 196-97; and Kelly, Pastoral Epistles (London: Adam and Charles Black, 1963) 258. Kelly observes:

Many prefer the translation "take up honourable occupations" but this introduces a theme which has no connexion with the context. Throughout the letter Paul is clearly concerned to stimulate good works among the Cretans (in harmony with his teaching in the Pastorals generally), where good works connote, not deeds by which men hope to acquire merit, but deeds of charity in the full Christian sense (258). 
this concluding admonition brings the Pastoral epistles perhaps into the realm of the Christian servant-ethic.

\section{The Servant-Ethic in Hebrews}

As Leonhard Goppelt says, the paraenes is of Hebrews concentrates "on the warning against irreversible apostasy."29 In terms of the servant-ethic, however, the pertinent passages in Hebrews look forward to the rewards of the faithful rather than the judgment of those who deliberately forfeit the grace of God. Scattered throughout the latter chapters of Hebrews we find those texts which bespeak an attitude of "other-directedness" and its consequences $(6: 10-12 ; 10: 32-39 ; 11: 24-26 ; 12: 14 ; 13: 1-3$, 16). The servant-ethic, to be sure, is not paramount in the writer's mind; there is much greater attention paid to the need for faithfulness.30 Nevertheless, especially as the epistle enters its final chapters, elements of the servantethic filter through as the writer seeks to encourage Christians in faithfulness, obedience and endurance.

In Hebrews service to God is paramount rather than service to others. Nevertheless there are traces of ethical content in Hebrews, many of which have a bearing on our

29 Theology of the New Testament I I (Grand Rapids: Eerdmans, 1982) 257 .

30 See, Harold W. Attridge, The Epistle to the Hebrews (Philadelphia: Fortress, 1989) 22-23. 
discussion. Chapter 13 of Hebrews is filled with ethical exhortation and consequently is considered an appendix by many. But we also find an explicit reference to serving the saints in 6:10, encouragement about mutual love and good works $(10: 24)$ and concern for imprisoned brethren $(10: 34)$ in the earlier chapters. The servant-ethic is implicit in each of these texts.31 Despite this, Jack sanders finds little ethical content in Hebrews that is exemplary, beyond general summonses to good citizenship. He concludes that the lack of eschatological urgency in Hebrews leads, in chapter 13 , to a simple recitation of examples of behaviour that "everybody knows is right and good."32

Sanders says of Hebrews that

the paranetic sections have precious little to say about one's ethical dealings with one's fellow men or with one's world but deal rather almost exclusively with the strictly religious ethical concern that the congregation "hold fast" to its "confession." 33

31 In 6:10 the readers are assured that the just nature of God implies that he will not forget their "service for the saints."

32 Ethics, 110. Sanders' overall thesis relies heavily upon the extent to which eschatological expectations provoke the ethical discussion of the New Testament writers. When a particular writer does not display a keen sense of eschatological urgency sanders usually finds nothing notable in that individual's ethical reflection. When eschatological expectations are heightened (as in the synoptic Jesus), the ethics are "invalid" (29). For the shift in eschatological focus from the imminent and universal to the eventual and personal, see Goppelt Theology 11,265 and Attridge Hebrews, 27-28.

33 Ethics, 106. 
He goes on to say that "the author of Hebrews thinks of

'love and good works'... as a subdivision of the broader category of keeping the faith." This is exactly the point of the servant-ethic. Subordinating one's own interests to those of others is not undertaken because such a stance is somehow "good and right" in itself but because one is a Christian. Becoming a Christian adds a new dimension to ethical behaviour. Certain aspects of ethics, of which the servant-ethic is perhaps the most notable, become paramount. Faith is seen as the foundation for doing what is "right and good" and points to a more demanding ethics than would be required by "good citizenship."

Sanders recognizes this in his discussion of chapter 13 and disputes that the requirements 1 isted there are the natural ethical outcome of the author's theological reflections :

The individual items of chapter 13 are there, not because the author has reflected on the ethical implications of his theological argument and come up with them, but rather because he already knows they are the right thing to do, already knows this because they are stock Christian teaching. 34

This is, of course, exactly true, and as such should not be presented as an indictment of Hebrews' ethics. The purpose of paranesis and exhortation is not to promote and justify new and extreme behaviour but rather to encourage others to

34 Ethics, 109. 
do the mundane, the difficult and the self-sacrificing,

often by citing motives that are guaranteed a certain appeal to one's audience. To please God, to seek his approval in faith and hope in light of the new covenant, is the ostensible motive of the echoes of the servant-ethic we hear in Hebrews. This is true even if these echoes do not directly radiate from the theological argument the author of Hebrews has presented prior to chapter 13.35 The focus of the motive in Hebrews shifts from Jesus as paradigmatic of self-denial and other-directedness, as we find in the gospels and in Paul, to one of fulfilling the terms of the new covenant God has established through Christ.36 in

35 The question of chapter 13 's place in the epistle has been debated although it is now generally considered to be original despite its tenuous link with the first 12 chapters. See Attridge Hebrews, 384-5. Also see J. Héring, who suggests that chapter 13 is a letter to a specific congregation attached to a general homily (The Epistle to the Hebrews [London: Epworth, 1970] 119). H.W. Montefiore rejects the suggestion that chapter 13 is Pauline and, like Hering, says the style and content "are sufficiently explained by the author's adaptation of his original homily to the needs of an ep ist le" (A Commentary on the Epist le to the Hebrews [London: Adam and Charles Black, 1964] 238).

36 This is not to imply that christ does not fulfill a paradigmatic role in Hebrews, for he undoubtedly does. As Schrage says:

The Christ event is central to the kerygma....1t is therefore not surprising that it is also cited as the motivating force in ethics. The focus is on the exalted Lord as Son and High Priest, but we also see Christ dying "outside the gate" (13:12), subject to temptation and suffering, sharing our trials and weaknesses $(2: 18 ; 5: 7)$. He is then not only the "pioneer" or source of eternal salvation (2:10; $5: 9-$ 10), but also its model (Ethics, 323). 
addition, of those named in chapter 11, who "died in faith," only Moses "who chose to share the ill-treatment of the people of God" $(11: 25)^{37}$ and Rahab, who "gave friendly welcome to the spies," conduct themselves in ways which may recall the servant-ethic. By this 1 mean that they willingly put aside their own interests in favour of those of others. Their conduct, moreover, does not serve as ethical motivation, but rather as an illustration of faith. it is this faithfulness, however, as it manifests itself in the Christians addressed by Hebrews, which gives rise to brotherly love, hospitality, and concern for those in prison. 38

Likewise, there is no explicit missionary impetus for the ethic as it appears in Hebrews, unlike 1 Peter. The Christians Hebrews addresses are not explicitly told to fulfill the ethical obligations set out in the epistle in order to promote the gospel outside the church. In fact, in

In 12:3 Jesus is referred to as an example of one "who endured from sinners such hostility against himself." While the accent here is not upon serving others but upon resisting sin, the characteristic of Jesus that is chosen is his endurance of hostility.

$37 \mathrm{Cf}$. Attridge (Hebrews) 357-8, who notes the parallels between Jesus and Moses at this point and the paradigmatic role of the former here.

38 See, 6:12, in which the addressees are called to imitate those who through $f a i t h$ and patience inherit the promises. This verse points ahead perhaps to chapter 11 and the examples therein. 
Hebrews, missionary activity seems particularly muted. 13:2 may encourage a willingness to be open to strangers on missionary grounds but the second half of the verse seems to militate against such an interpretation. Nevertheless, in 12:14 readers are encouraged to "strive for peace with all men," an admonition which is linked in the second part of the verse with "holiness." Peace is a worthy goal in itself and there is no explicit missionary motive; however, such behaviour may be encouraged to moderate the suffering the readers face at the hands of non-christians or to overcome divisiveness within the community. ${ }^{39}$

Hebrews concentrates on theological themes rather than ethical exhortation. What ethical instruction there is, however, is "other-directed" and includes brotherly love and hospitality. In addition, the faithful endurance of the addressees often involves the foregoing of retaliation and vengeance in the hope of receiving a greater reward in the future $(10: 32-36 ; 11: 25 ; 12: 2-3)$.

The ethical horizon of Hebrews tends to extend only to the limits of the community. Beyond that there is no instruction other than to endure hostility and to strive for peace with others $(12: 14)$. Within the community there is to be special concern for those in prison. In two places

39 See Montefiore, Hebrews, 223; and B. Lindars, The Theology of the Letter to the Hebrews (Cambridge: Cambridge University Press, 1991) 114. 
the author reminds the readers of their solidarity with those in prison $(10: 34 a ; 13: 3)$ In the first instance the author calls for compassion (synepathesate) toward the imprisoned, and in the second, the need for total empathy with the incarcerated (hōs syndedemenoi). In the context of the letter these verses serve to place the suffering and endurance of the readers into a larger perspective: not only should one joyfully and faithfully accept one's own hardships but one should also be acutely aware of and respond to the suffering of others. These two verses alone lift the ethical concerns of Hebrews from the reaim of deportment "equated with good citizenship," to use sanders" phrase, to a moral scheme which understands "otherdirectedness" and empathy as paramount.

The servant-Ethic in James

The epistle of James is one of the most controversial books of the New Testament. Its canonicity was questioned throughout the early Church and Luther's famous verdict ("an epistle of straw") still finds echoes in scholarship today. 40 James stands in tension with Paul primarily because he links "works" with justification, but also because the epistle lacks any explicit (and many would say

40 For a thorough discussion see Dibelius, James (Philadelphia: Fortress, 1976) 51-57. 
implicit) christological statements.41 Fortunately our task is not to evaluate the debate about James's authorship, date, circumstances of composition, or merit. As an early Christian document which is fundamentally paraenetic in character it is territory that needs to be explored in our pursuit of the servant-ethic. 42

41 Leander $E$. Keck says that despite James's insistence on faith and works, the moral obligation in Paul is stronger because it is grounded in Christ's death and resurrection:

Paul's understanding of faith does not dissolve obligation, nor does his understanding of obligation undermine $h$ is contention that faith is adequate to relate one rightly to the righteous God. When the epistle of James polemicizes against a separation of faith from works, and contends that "one is justified by works and not by faith alone" because "faith apart from works is dead" (Jas 2:14-26), it is not Paul that is hit by this salvo but a vulgarized "Paul" who has been distorted into implying that faith is assent to doctrines. Paul's sense of moral obligation is not one iota weaker than that of James. For Paul obligation is grounded in the Christ-event and in the impingement of the new creation on the present age whose time is running out, whereas for James obligation is not grounded christologically at all. Therefore obligation in Paul is actually stronger (Paul and His Letters [Philadelphia: Fortress, 1979] 91).

42 Some have even questioned whether James is in fact a christian document, suggesting that it is rather a Hellenistic Jewish text that has undergone interpolation at $1: 1$ and $2: 1$ (see Dibelius, James, 21-2). Whether or not this is true (and scholarship now seems to lean away from this possibility), James was understood by some Christians to have value and authority. Dibelius' characterization of James as paraenesis seems sensible even if this leads him to the conclusion that the letter is late (3-5), despite the "Jewish" character of the epistle. 
The words doulos and diakonos do not occur in the epistle, except at $1: 1$, where the author styles himself a "slave of God." Nevertheless the epistle contains many exhortations to selflessness and service to others that resonate with the servant-ethic already delineated in the gospels and Pauline writings.

One possible example of the servant-ethic is the exhortation in $2: 8$ to fulfill the love commandment, which James describes as the royal law. This royal law forbids partiality to the rich. This prohibition is illustrated by 2:1-7 and James's condemnation of those who favour the rich and disregard the poor in the syngoge. James opposes these practices not by claiming the impartiality of God as a paradigm (as we find in Matt $5: 43-48$ ), but by picturing God as actively on the side of the poor. ${ }^{43}$ For James partiality means honouring the rich because they are rich. The opposite idea of impartiality then becomes displaying respect to the poor. In other words, the poor are to receive equal respect and their needs are to be cared for. This is confirmed by $2: 14-17$, in which James reminds his

43 Jouette M. Bassler understands 2:5 differently. She says, "He grounds this exhortation (2:1-4) in Deuteronomic fashion by pointing to God's own impartiality in choosing the poor of this world to be $r i c h$ in faith and heirs of the kingdom which he has promised to those who love him" " (Divine Impartiality [Chico: Scholars Press, 1982] 180). 1 would argue however that God serves here as a model not of impartiality but of actively favouring and honouring the poor. 
readers of their responsibility to the naked and hungry in their community, and also in $1: 27$ in his description of "true religion." Again we hear echoes of Matthew and the judgment on those who fail to respond to others' needs (Matt $25: 31-46)$.

James's call to impartiality then becomes a summons to serve, or at least to honour, the poor. 44 He reminds $h$ is readers in 2:6 that not only have they dishonoured the poor but actively have furthered the ambitions of the rich who are their oppressors.45 James seeks to address a community

44 Peter H. Davids says:

The Christians do not simply discriminate against the poor, but they do so in favor of the $r i c h$. This means that they are siding with the very class which both historically and at present persecutes the impoverished believer. They have made the church into a tool of persecution (The Epistle of James [arand Rapids: Eerdmans, 1982] 112).

45 It is difficult to accept that $2: 1-7$ is not addressed to a specific tendency with which James is familiar. Thus a though the epistle may be characterized as general paraenesis these verses seem to apply to a specific situation. See Adamson, James: The Man and his Message (Grand Rapids: Eerdmans, 1989) 254, who dates the ep istle very early and sees in the reference to courts "habitual harassment" of Christians by Jews of the sort Paul engaged in prior to his conversion.

Dibelius expressly cautions against such a reading. He says of $2: 2-4$ :

What we have here is in fact an example, and not a special case which has motivated the introductory admonition; and this example is narrated without any concern for its reality, and hence, without any consideration of the question of the community in which, or the circumstances under which, this or even something like it could have taken place (James, 125 ). 
in which wealth, social status and prestige determine one's position in the eyes of others.46 This is not only partiality but is against God's law, and the author reminds his readers that such activity renders them liable for judgment ( $2: 13)$. While Dibelius is correct in cautioning against inferring a crisis in the community or communities on the basis of Jas $2: 2-7$, it is clear that James sees the true Christian community as one that rejects, or rather should reject, "worldly" standards of honour and prestige. such a picture of the church does not constitute an explicit call to the servant-ethic, but it is indicative of the attitude that usual perspectives concerning status and esteem are to be rejected in favour of a perspective that recognizes that social status and wealth are not evidence of God's approval and that the more lowly position should be sought.

In James the figure of Christ is not mentioned as paradigmatic, an incentive found in Paul and the gospels for the servant-ethic. The readers are to serve the poor in

This would be easy to accept were it not for verse 6 and the reference to the readers being dragged into court. While 1 , like Dibelius, do not believe that the reference is to systematic persecution of Christians by either Jews or Gentiles, the inclusion of court-action with the vaguer references to oppression and blasphemy points to a more specific situation than Dibelius allows.

$46 \mathrm{Cf}$. Adamson, James: The Man and the Message, 231-239 for socio-economic conditions in first century Palestine and the consequences thereof. 
for the servant-ethic. The readers are to serve the poor in order to practice true religion and thereby incur God's favour (e.g. $1: 27 ; 2: 15-17$ ). For James the coming of the Lord is at hand $(5: 7-8)$, but this expectation is to be tempered with patience. Practically every section of paraenesis in the epistle points to the judgment, blessing or reward from God as a consequence of action (e.g. 1:12. $15,25 ; 2: 13 ; 3: 1 ; 4: 10-12 ; 5: 1,9,19-20) .47$

The emphas is upon honouring and helping the poor while eschewing snobbery shifts the focus of the servantethic in James. James's readers are called upon to meet the temptation to disdain the poor with compassion and concrete aid. The limitations of James in terms of "otherdirectedness" are reflected in his uncompromising opposition to the $r i c h$ and $h$ is implicit requirement of serving the poor. For James, on one level at least, salvation is achieved only through "enmity with the world" or, to put it more accurately, not through friendship with the world (4:4). James makes no mention that $h$ is readers should attempt to welcome more rich oppressors into the community. Piety, in James's view, manifests itself in rigorous regard for the welfare of others. James encourages his readers to

$47 \mathrm{Cf}$. Schrage, who says:

The epistle of James records primarily a motivation [for ethics] based on an eschatology of the future, even expectation that the end of the world is imminent (Ethics, 285). 
action, born of wisdom, is to be the order of the day. 48 Conventional standards of those outside the community are to be eschewed when they serve to promote selfish gain, ambition and jealousy. The poor are to be served. In James, therefore, the limitations of what we have termed the servant-ethic are more sharply defined than in either paul or the Gospeis. James does not advocate submitting to and loving one's enemy unreservedly. James may be said to strike a cautionary note in taking the servant-ethic and the principle of other-directedness too far. The rich are not to be served and honoured at the expense of the poor. The epistle points out how the servant-ethic may be abused should it become abject servility towards the rich for the sake of satisfying one's own snobbish instincts.

3:13-18 gives the foundation for James's ethic. Anyone who is wise will reveal his or her wisdom by works (3:13). True wisdom, the wisdom from above, precludes selfishness and ambition, and is manifested in peaceableness, mercy and reasonableness. Those who are wise, who seek to do God's will, are not jealous or ambitious; they seek to make peace. It is in these verses that the servant-ethic, or at least the underlying attitude of the ethic, is most clearly expounded in James. The word

4 As Victor Furnish has pointed out, in James divine Wisdom is "the essence of God's gift, to be sought and received by faith and then exhibited in an upright 1 ife" (The Love Command, 181). 
eritheia ( $3: 14)$, which is translated "selfish ambition" in the RSV, points, as Mitton says, to conduct that is clearly contrary to the servant-ethic. Eritheia "is the determination to get what one wants in position and power, no matter what bitterness and $i l l-w i l l$ are caused." 49 such an attitude recalls that which Jesus opposed in his rebuke of James and John (Mark 10:42-45). True wisdom is the way to overcome the disorder and vile practises born of earthly or unspiritual wisdom.50 James is a call to put into practise the consequences of faith in Christ, even if this is not explicitiy stated in the letter. His emphasis upon the just treatment of the poor has made the epistle especially appealing in the context of liberation theology.51

\footnotetext{
49 The Epistle of James (London: Marshall, Morgan and scott, 1966) 137.

50 In his discussion of "pure" in 3:17, Mitton says:

God's wisdom as bestowed on man reveals itself in conduct which is pure (hagné). This means that it is free from self-interest and selfish ambition (James, 140).
}

While Mitton may be pushing the limits of the meaning of the Greek hagne- here it is clear that the overriding thrust of the passage in James is to promote a manner of conduct that bespeaks the servant-ethic. Thus Mitton has grounds to define "gentle" (epieikēs) in the same verse as applying to the one who "does not stand on his own rights" (James, 140), which again recalls the servant-ethic.

5 isee for example Elsa Tamez, The Scandalous Message of James (New York: Crossroad, 1990). Although questions of authorship are not our focus it is notable that in Eusebius account of Hegesippus' report of the martyrdom of 
The Servant-Ethic in 1 Peter

"Reading the first epistle of Peter immediately after the epistle of James... one suddenly gains the impression of being enveloped in a much more ardent glow of faith." 32 Schnackenburg continues, however, that like James "this writer's principal concern too is with religious moral exhortation." 53 I Peter encourages its readers to display appropriate behaviour before others. Much of this behaviour is constitutive of the servant-ethic.

The writer of I Peter is especially concerned with his readers' behaviour in the sight of outsiders. At $2: 12$ he beseeches them to "maintain good conduct among the Gentiles." 34 part of this conduct involves respecting human

James the Just (bishop of Jerusalem), the scribes and Pharisees seek to coax the people away from Christianity with James's testimony. In that passage these officials describe James as "just and no respecter of persons" (Eusebius, Ecclesiastical History, $x \times i i i$ ).

52 R. Schnackenburg, The Moral Teaching of the New Testament, 365-66.

53 Moral Teaching, 366.

54 See I Peter 1:15. Selwyn traces this back to Matt 5:16 (The First Epistle of Saint Peter [London: Macmillan, 1964] 170, 373). Based on his examination of the literary structure of 1 peter, Kendall notes that doing good includes being submissive and honouring all persons $(2: 13-17 ; 3: 1-2$, $7,8)$, suffering unjustly $(2: 18-19 ; 3: 9-14 ; 4: 1-6)$, repudiating vengeance $(2: 19-23 ; 3: 9,15-16 ; 4: 1)$ and loving fellow believers $(3: 8 ; 4: 7-11)$. "When believers "do good" they prepare themselves for the consummation at the revelation of Christ and, in the process, their lives bear witness to God's grace before non-believers ( $2: 12 ; 3: 1-2)$ " ("The Literary and Theological Structure of I Peter 1:312 ," in Perspectives on First Peter [Macon, Georgia: Mercer 
institutions. In addition, when any of the readers are reviled or slandered, the abuse is to be suffered quietly $(3: 9,13-16 ; 4: 4-5,14-16)$. Amongst themselves the readers are to have "unity of spirit, sympathy, love of the brethren, a tender heart and a humble mind" (3:8). They are to practice hospitality ungrudgingly (4:9), and the elders are not to domineer the group but are to be examples (5:13).

As Victor Furnish points out, however, the love commandment of Jesus and of LeV 19:18 is not to be found in 1 Peter. Nevertheless, Christians are called to love one another and to behave appropriately towards those outside the fellowship.5s Like Furnish, Schrage believes there is no particular emphasis upon the law of love although philadelphia is invoked repeatedly $(1: 22 ; 2: 17 ; 3: 8) .56$ In I Peter "ungrudging" hospitality towards one's brothers and sisters is an expression of philadelphia. As Schrage says, " 'ungrudgingly" reminds us that hospitality can be...

University Press, 1986] 112).

55 See also Beare: "The regenerate life is lived in the community of God's people and finds its necessary expression in the "love of the brethren' $(1: 2)$ and in mutual service (4:8-10)" (The First Epistle of Peter [Oxford: Basil B lackwell, 1961] 39).

56 Ethics, 274 . 
burdensome, costing both time and money and requiring selfless love."s 7

2:16-17 sums up the ethical content of the epistle. Furnish notes that $2: 16$ is the only reference to freedom in the epistle and, like Gal 5:13, it is paradoxically aligned with bondage:

But whereas Paul had spoken of using one's
freedom to bind oneself in loving service to
others. . this writer speaks of being bound in
service to God... But vs 16 should be read as
an introduction to vs. 17 , and in this
following verse it becomes apparent that also
for the author of I Peter bondage to God
involves the practice of love in one s
life... The commands to "love the
brotherhood" and "fear God" form a distinctive
but recognizable version of the double
commandment of the synoptic tradition: the
essence of obedience is to be rightly related
to God and to one's brother.se
In addition, the command pantas timesate (honour

everyone) shows that not only are the brethren to be loved but that believers have an ethical responsibility to all people.s9 As well as showing love to their brethren, believers are to show honour to all in their role as servants of God. As Allen Verhey says, "Faith exists as

\section{Ethics, 275.}

58 Furnish, Love Command, 164, emphasis his. We should note, however, that the double commandment is not so 1 imited in the synoptic literature. (Beare insists that $v .16$ is "not to be taken as subordinated to the imperatives in the following verse" [1 Peter, 117].)

39 peter $H$. Davids points to Jas $3: 10-12$ and m. Aboth $4: 1$ as expressions of the same point (The First Epistle of Peter (Grand Rapids: Eerdmans, 1990), 103. 
obedience, and obedience exists as love no less for Peter than for Paul."60

The emphasis upon enduring unjust suffering is part of the Petrine ethic. The motives for such suffering are varied but they have to do with the obedience to God which permeates the paranesis of the author $(1: 14,22)$. As Schnackenburg says, "The epistle puts forward an abundance of truly Christian motives for readiness to suffer and trial by suffering." In addition, Schnackenburg notes that the author tells slaves that "with God suffering is a grace $(2: 20)$ " and that "Later, they [Peter-silvanus] offer the same arguments to all Christians (3:17f.)."6l The example of Christ's sufferings, however, is also allied with his ultimate vindication and glorification, which inspires hope $(1: 21 ; 4: 13-14)$. There is, moreover, the implicit sense that Christians should endure suffering as christ did as a means of honouring or revering him $(3: 14-15) .62$

6 The Great Reversal, 138.

6 IMoral Teaching, 370.

62 For a brief discussion of ethical motivation in 1 Peter see Schrage, Ethics, 269: "The real and ultimate basis for ethical exhortation [in I Peter] is christological and soteriological." He admits that sometimes this motivation is "sounded somewhat formulaicly" as in 3:16 and $2: 13$, but also points to other passages in which the motivation is more completely described and readers are reminded of the suffering Christ endured to complete $h$ is salvific work $(3: 17-18 ; 2: 21-25)$. 
Finally, the selfless conduct of christians no matter what abuse they may face, and their rigorous refusal to disrupt the institutions of society, including the patriarchal household and government, would, the author believes, bring others into the community of christians:

Christians were supposed to bear witness to the gospel that sought to save all people through christian conduct in the institutions of society. While the Qumran community in the process of emigration armed itself as a community of action for the holy war against the unrighteous ones, the Christians were supposed to sojourn among people, as their Lord had done, and also through their conduct in politics, economics and marriage let it be known that God desired to lead all into a whole human existence. Socio-ethical responsibility motivated by the love of God stood here within the brackets of the missionary commission. ${ }^{63}$

1 Peter, then, is more compromising than James in accepting the social structure of society at large. Established human authority in the domestic and political spheres is to be respected even if believers incur unjust suffering. The self-interest of individuals is to be surrendered in the interest of bearing witness to the truth of the Gospe1, which in the long run will serve the interests of society as a whole.64

salvific work $(3: 17-18 ; 2: 21-25)$.

${ }^{6} \mathrm{~L}$. Goppe1t, Theology of the New Testament $11,167$.

64 The Christian wives who seek to win their husbands "without a word" exemplify the missionary strategy of 1 Peter: 
This strategic, missionary motivation for self-denial in 1 Peter does, however, have some drawbacks. While the focus for ethics in 1 Peter is much broader than, say in James, there are dangers inherent in 1 Peter's approach. Being subject to every human institution, for example, led to a particularly notable development in the petrine Haustafel.

The Haustafe in texts in the New Testament have often been criticized as examples of how early christianity capitulated to social institutions and mores that were burdensome for many people. I peter is perhaps most susceptible to such a critique.65 Jack Sanders, for

The author expects missionary success from christian life, lived in the power of the Word and representing its reality-not with a zeal for conversion, but in the knowledge that one's life is a form of proclamation, which can affirm or deny the authenticity of the gospel (Schrage, Ethics, 274).

65 See, for example, Elisabeth Schüssler-Fiorenza, In Memory of Her, 251-270, and Jack Sanders, Ethics in the New Testament, 75, 85. In / Peter there is no address to masters to balance the one to slaves and in the address to slaves christ is seen as paradigmatic of the suffering slaves are counselled to accept with equanimity. While this does not actually give approval to the institution of slavery, some argue that it accords it connotations of nobility since patient endurance of suffering is advocated. Some find this distressing, although others are able to infer from this text a subversion of slavery:

Subordination now signifies submission to God's will and solidarity with the obedient servant Lord (2:1825). In this brotherhood all members are co-heirs and household stewards of God's grace $(3: 7 ; 4: 10)$. While this represents no frontal assault on the institution of the Hellenistic household, it also constitutes no case of total capitulation to pagan 
example, criticizes the Haustafeln for corrupting the agape

ethic found in Paul:

He [Paul] knew that the Christian who loves goes out of the world by going out of himself for the welfare of his fellow man. This may certainly be understood as submission, as self-sacrifice--but for the other. Once the Haustafeln, however, came into the Pauline tradition, it was probably inevitable that someone would "Christianize" one as the author of I Peter did. But to Christianize by institutionalizing!... All interest in one's fellow man is out, concern for living up to a standard of personal submission for one's own sake, is in.66

Sanders is correct that the slave's patience in suffering, according to I Peter, will ultimately bring God's approval and that there is no explicit benefit for the unjust master, but he is too harsh when he suggests that "all interest in

Georgia: 1986] 71, emphas is $h$ is).

For a full discussion of Christian attitudes to slavery see John M.G. Barclay, "Paul, Philemon and the Dilemma of Christian Slave-Ownership" (NTS 37 [1991] 161-186).

Barclay points out that while slaves were assured "freedom in Christ," this did not translate into a movement towards abolition of the social institution of slavery:

It is difficult to see more than wishful thinking in the statements of those who think that Paul subtly undermined slavery and who represent the various abolitions of slavery in the nineteenth century as the inevitable result of the teaching of Paul (or the NT generally). There was nothing especially revolutionary in the fact that paul treated slaves as human beings, urged their humane treatment and even called them "brothers," so long as he did not spell out any practical implications which could conflict with the continuing practice of slavery $(184-85)$.

6 Ethics, 85, emphasis his. 
one's fellow-man is out." This is revealed in two ways: First, the role of christ as paradigmatic is the role of one who suffers unjustly on behalf of others $(2: 21 ; 3: 18)$. Believers who endure slander and other sufferings at the hands of outsiders are promised that these very opponents will come to a realization of the $\operatorname{truth}(2: 12)$. Second, the address to wives explicitly calls for submission before husbands in the hope that some of them at least "may be won without a word." This emphasizes the insistence throughout I Peter that the truth of the gospel is to be made evident through the behaviour of Christians rather than merely through their speech.

The idea that it is especially the unjust suffering and submissive behaviour of Christians that illustrates God's will and glory to non-believers is evident elsewhere in 1 Peter $(1: 12,15 ; 3: 1-2 ; 4: 4-6)$. This could, and does, lead to the acceptance of injustice. This, however, is the price that must be paid, according to 1 Peter. Such suffering finds its paradigm in the one who paid a far greater price for the sake of many. 67

67 It is one of the scandals of Christian history that 1 Pet 3:1-6 and its parallels (Col 3:18; Eph 5:22) have been used many times to induce a woman to remain in an abusive marriage "as is fitting in the Lord." That such marriages existed in the time I peter was written is likely. As Balch says, after acknowledging the missionary motivation for the passage:

The final phrase in the pericope, that the wife should not fear any terror $(3: 6 c)$, indicates that 
1 Peter, to be sure, does not wax eloquent and at length on the need to place the interests of others first and one's own last. The entire epistle, however, with its emphasis on maintaining good conduct in society no matter what the cost in unjust suffering, endeavours to encourage believers to be living witnesses to the gospel in the hope that this will lead others to obey God. As Beare says:

To suffer for doing good and to bear the suffering patiently, without retaliation or threatening, is the genuine mark of the Christian, wherein he follows the example set by Christ himself.68

Christians therefore

are to accept in submissive humility the inequalities and injustices of the society in which they live, for this is God's will. The new sense of spiritual freedom must not move them to break the bonds of authority. 69

the ethic being taught to the wives was not only missionary but also apologetic. The verses addressed to wives were meant for Christian women who were suffering because they lived in households which were only partially Christian, households in which Romans perceived a lack of orderly submission and harmony (Let Wives be Submissive [Altanta:

Scholars Press, 1981] 121).

We cannot tell how much suffering a Christian woman would have to endure at the hands of her pagan husband before the early church would relieve her of her role as a missionary. Even Paul, in I Cor 7:10-16, leaves the dissolution of the marriage in the hands of the unbeliever, although $v .11$ seems to offer a woman a way out if necessary.

$$
\begin{aligned}
& 68 \text { Beare, } 1 \text { Peter, } 41 . \\
& 69 \text { Beare, I Peter, } 40-41 .
\end{aligned}
$$


The author of 1 Peter, therefore, despite his emphasis upon philadelphia, believes that selflessness transcends the boundaries of the community, as is evident in his insistence that the Iives of Christians bear witness to the truth of the gospel. Commenting on 3:9 schrage points out that in 1 Peter, "contrary to all common sense and logic, evil is to be answered with good, cursing with blessing. 70

Verhey summarizes the goal of such an approach as doing what is right "in terms of the Christian paraenetic tradition and in terms of what is universally acknowledged as responsible conduct" rather than the Mosaic law. He asserts that:

Indeed, to be freed for the service of God is to be freed to "be subject for the Lord's sake to every human institution" $(2: 13)$. It is God's will that Christians should live lives beyond any possible reproach. Such lives will silence their detractors and be serviceable to the missionary enterprise of the church.71

Conclusions on the remaining books and the servant-ethic

As we move away from the gospels and the undisputed letters of Paul we can see that the boundaries of the servant-ethic tend to turn inward towards others within the Christian community. Nevertheless, important aspects of

70 Ethics, 275 .

7 The areat Reversal, 139. 
the ethic continue to radiate out to the world at large. Even the Pastoral Epistles reveal echoes of the servantethic. Colossians and Ephesians with their emphasis upon the transformation of human nature through belief in christ also show the particular foundation of New Testament ethics. This foundation is illustrated in Acts by the jailer and Simon Magus. The former responds to the truth of the gospel and his response is manifested in service. The latter seeks personal glory and therefore risks judgement. The most significant aspect of the ethic in the remaining texts is the call to endure unjust suffering at the hands of others. In I Peter such behaviour has an explicit missionary impetus, while in Hebrews and James it is undertaken in the hope of future exaltation by God. We should remember that such a motive is also offered in the gospels and we need not shirk from concluding that the promise of future reward encouraged many early Christians to endure injustice patiently. This is a testament to their faith and is described most explicitly in Hebrews, but also occurs in I Peter and even (!) James.

It is apparent that the writers of these three epistles found that their experience as Christians alienated them from the world at large. Their ethics reflect this alienation in their emphasis upon enduring injustice. For James the alienation is mirrored in a retreat from the world and its values (by eschewing snobbery and championing the 
poor), while Hebrews insists on special compassion for those who suffer in prison. I Peter is also aware of the need for faithful endurance of injustice but understands this as an opportunity for missionary activity. All three of these writers understand the christian life to be one of personal sacrifice. They encourage their readers to continue to take up their crosses secure in the faith that "whoever loses his life" for the sake of the gospel will save it.

\section{A NOTE ON 11 PETER AND JUDE}

In our investigation thus far we have found at least traces of the servant-ethic in all parts of the New Testament, with the exception of $1 /$ Peter and Jude. In these two epistles the sparse ethical content does not yield much in our attempts to pursue the servant-ethic. In 11 Peter the only text which is pertinent is $1: 7$ which encourages readers to supplement their "godliness with brotherly affection and brotherly affection with love." This is standard Christian paranesis and reflects how much such ideas permeate the consciousness of the writers of the New Testament. Likewise, in Jude 12 those who "boldly carouse together, looking after themselves" are obviously engaging in behaviour inappropriate for Christians. They serve as an example of how not to behave, apparently because they satisfy selfish desires (follow their own passions, v.16), rather than looking to the interests of others. In 
both these epistles the emphasis is upon avoiding the wicked ways of others and preserving the Christian life from worldly corruption. In essence they are the exceptions that prove the rule: The servant-ethic characterizes early Christian paranesis, encouraging an extreme degree of selfdenial and other-directedness. 


\title{
$\checkmark$ THE EARLY CHRISTIAN SERVANT-ETHIC--CONCLUSIONS AND IMPLICATIONS
}

\begin{abstract}
The call to....service we find only in the presence of another, whose need is often the very occasion of our freedom. For it is through the need of another that the greatest hindrance to my freedom, namely my own selfabsorption, is finally not so much overcome as rendered irrelevant.1
\end{abstract}

The sense that the interests of the self must be overcome or set aside if a believer is to abide as a Christian and in the will of God permeates the early Christian documents that we have covered. For many scholars this selflessness manifests itself as agape love. Scholars who seek to find a unifying ethical theme in the New Testament often focus on the theme of agape. Love, however, has to be put into practice; it has to be expressed. Invariably these scholars come to the conclusion that to love means to serve others.2

1 Stanley Hauerwas, The Peaceable Kingdom (Notre Dame, Indiana: Notre Dame University Press, 1983) 44.

2For example, in his book Christian Neighbour-Love (Washington D.C.: Georgetown University Press, 1989), Garth Hallett examines six rival versions or descriptions of love advanced in Christian thought, to see which comes closest to the New Testament concept of agape. The six versions he identifies are: (1)self-preference, (2)parity, (3)other-preference, (4) self-subordination, (5) selfforgetfulness and (6)self-denial. This is a continuum of sorts in which the interests of the self are pitted against 
the interests of others to a greater or lesser degree. Hallett believes that the New Testament comes down in favour of self-subordination (47-62). He says:

in this understanding of neighbor-love, one may and should give independent consideration. to one's own benefit, but only on the condition that maximum benefit to others is first assured (whether directly or indirect $(x)$, through benefit to oneself. (lbid., 5, emphas is his.)

Hallett allows, however, that some parts of the New Testament are more extreme, implying that self-forgetfulness (in which the benefit to the self is not given any independent weight), or even self-denial (in which benefits to the self are never sought save to maximize benefits to others), are required. Hallett believes that while the diakonos and doulos vocabulary of texts such as Mark 10:4245; John 13:14; Phil 2:5-7 and Gal 5:13 might suggest otherwise, he asserts that $h$ is category of selfsubordination is echoed most consistently in the New Testament:

From texts like these, no strictly logical inference can be drawn to the norm of selfsubordination (countenancing good to self only when it does not conflict with others' good). However, the texts do, on the one had, clearly suggest a more purely altruistic norm than other-Preference (which permits the agent's good to compete, if only minimally, with others'), but do not, on the other hand, suggest a more total self-denial, disconnected from service.(1bid., 47.)

While Hallett's evaluation may be overly schematised, 1 think his estimation of the New Testament approach to neighbour-love is correct. While the christian is undoubtedly to look to the interests of others, its view does not favour the absolute denigration of the self. Nevertheless, the call to serve others is consistently invoked in the New Testament. As Thieme notes:

Die Willigkeit zu irgendwie niedrigem wirken ist das Characteristische der Menschenliebe in der Christenheit: sie ist es, die den Christen zu einem "Diener" seiner Mitmenschen macht. 
It is important to recognize also that the idea of love is not the most important element in the New Testament writings. While love is a significant theme in the New Testament, it does not constitute the central message. The person and message of Jesus do not provoke a call first to agape $\bar{e}$, according to the New Testament, but rather a call to a fundamentally new orientation. Only after repentance (or conversion) has occurred can love become constitutive for Christian action. ${ }^{3}$ In a sense, the ethics of the New Testament writers are worked out in light of the person of Jesus and the believer's response to him. The question is not how one should act but how the believer should act. often, the believer should act in ways that any other person should act, whether they be stoic, Jewish, Buddhist or pagan. It is the grounds of this action that differs--for the earliest christians it proceeded from a profound selfawareness of the requirement to serve others because of the reconciliation God achieved with humanity through Christ.4

(Die christliche Demut, 205).

${ }^{3}$ Childon and MacDonald make this point in Jesus and the Ethics of the Kingdom when they say:" The programmatic centre of Jesus' ministry was not the concept of love, but that of God's rule" (3). While they are focussing on the synoptic record a similar viewpoint is found in Paul and John. Christian love does not and cannot proceed from a person unless he or she has come to an affirmative decision about the person of Jesus and his role in God's scheme.

4 Scholars such as John Howard Yoder speak of this reconciliation in terms of revolution and understand it to have profound implications for Christian ethics, even when 
The earliest believers, as their views are

expressed throughout the New Testament, then, saw service to others as the predominant characteristic of the Christian life. While the content, motives and limitations of this characteristic vary from book to book, there is an inherent coherence in each which can be demonstrated.

The Content of the Servant-Ethic in the New Testament

There are four primary elements that constitute the servant-ethic in the New Testament writings. We shall

those ethics do not greatly vary from those found in other traditions. Although the early Christians accepted the requirements of living up to one's role in society, "The meaning of that role was changed in substance by the stance of servanthood derived from the example and the teaching of Jesus himself." For Yoder the "revolution" occurs not in visible social reform but in the transformation that occurs in believers' self-understanding. Jesus" "motto of revolutionary subordination, of willing servanthood in the place of domination," achieves two ends while essentially leaving the social strata untouched. First, it allows those in subordinate social roles to accept their position without resentment and second, it persuades the person with more status to "forsake or renounce all domineering use of $h$ is status." Yoder says that now the subordinate person "becomes a free ethical agent when he voluntarily accedes to this subordination in the power of christ instead of bowing to it either fatalistically or resentfully" (The Politics of Jesus [Grand Rapids: Eerdmans, 1972], 190-191). Eduard Lohse also acknowledges that the ethics of the New Testament writings include moral maxims from other sources. It is how these maxims can be fitted in with service that makes them adaptable to the early Christian view of ethics. Lohse notes that love becomes the grounds for embracing moral principles: "That love that does not seek its own advantage, but the good of the other, places itself as the critical orientation point for evaluating the variety of traditional ethical maxims in circulation" (Theological Ethics of the New Testament [Minneapolis: Fortress, 1991] 220). 
consider each in turn before identifying the underlying connection.

\section{1) The Call to Love Others}

In the synoptic gospels the neighbour is the other person. That person may be friend or enemy but in every case the believer is called to show love unrestrictedly. The synoptic gospels are forthright in their portrayal of the stance of the self before others. Following Jesus requires extreme self-denial. The interests and even the demands of others are to come first.

In the Johannine writings the neighbour primarily is restricted to those within the christian community. Loving service takes place above all within this context and is exemplified by the footwashing episode.

In Paul love of neighbour refers most often to the believer's Christian fellows, but he also insists that it must extend beyond the community. Paul's ethic includes accommodation to the scruples and claims of others. For Paul the Christian 1 ife requires that one stand ready to serve others.

In I Peter Christians are called to honour all people and to love the brotherhood. In | Pet 3:9 they are called to return evil and reviling with blessings. Likewise in James believers are called upon to offer practical assistance to those in need $(1: 27 ; 2: 14-17)$ which is a mark of a living faith and true religion. 


\section{2) The Call to Serve the Poor}

Related to the call to love others is the requirement to take on a special responsibility towards the poor. ${ }^{5}$ As we have noted above, the poor play an important role throughout the biblical literature, in revealing the mercy of God. Service to the poor becomes service to God because it manifests his mercy. There is also a sense that Christians are to identify with the impoverished, at least in the sense of living without reference to material wealth. Luke gives this injunction special prominence with, for example, the emphases in the story of Zaccheus (19:1-10) and the accounts in Acts $2: 44-47$ and $4: 32-35$ of the distribution of surplus possessions to those in need. The other two synoptic gospels also reflect a concern for those who are without money, often in the context of alerting the believer to the danger of wealth that is not distributed (e.g., Mark 10:21). I John $3: 17$ and its insistence that love is expressed in concrete help towards one in need reflects a similar view, and that the practice is a primary focus of James hardly needs to be mentioned. Even I Timothy and its so-called bourgeois ethic insists that the wealthy must be generous (eumetadotos) and liberal (koinönikos) (6:17-19). Material wealth is no longer a means of security. The

${ }^{5}$ of all ethical injunctions, almsgiving seems to have a common emphasis in all religious traditions. It is one area in particular where the human religious impulse strikes a universal note. 
willingness to give, rather than to retain, one's

possessions is a mark of the servant-ethic.

\section{3) The Call to surrender One's Rights}

In the Bible justice becomes the manifestation of God's righteousness and mercy.6 The servant-ethic advances justice by calling one into conformity with the will of God, the God of justice. Curiously but necessarily this means that on some occasions justice forbids that one's own rights should be asserted in its name. The New Testament writings frequently call their readers to go beyond an understanding of justice based on external dictates of equity between persons, at least insofar as the self is concerned.7

There is also a sense, then, in which justice as equity becomes as it were a non-issue, rather than being superseded, especially as manifested in the servant-ethic. Here rights and formal duties fade from view. Love ignores the claims of justice insofar as the self no longer seeks its own rights but simply looks to the interests of others. Justice remains with the one alone who is just--God.

See Gardner, 257-259.

7 As Reinhold Niebuhr has said, In so far as justice admits the claims of the self, it is something less than love. Yet it cannot exist without love and remain justice. For without the 'grace' of love, justice always degenerates into something less than justice (Love and Justice [Philadelphia: Wesminster, 1957] 28). 
The only "rights" that a Christian has are those granted by God. But the believer can make no claim on God. The gift of the truth as manifested in Jesus Christ demands reception or rejection. If the gift is acknowledged the believer stands in the realization that every act must now be conducted in light of divine grace.8 There is no room now for selfish ambition or arrogance. The claims of others supersede the claims of self even when the former are unfair.9 Thus the believer is sometimes called to go the

\footnotetext{
- Josef Pieper explains that human beings can never make a claim on God because they owe their very existence to him. This is a debt that can never be fully discharged (Justice [New York: Pantheon Books, 1955] 96-97). In his conclusion to his essay on justice he asserts that because injustice prevails it is necessary for the just person to give beyond what is strictly due (ibid., 107).
}

In his discussion on "The Human Good," Bernard Lonergan notes that egoism is in conflict with the good of order and that the legal and judicary systems can never fully contain the assertion of self. In his view the law becomes more tolerant since not every infraction can be dealt with. This leads not only to the deterioration of the good of order but it also means that justice is compromised since "The practical question is apt to be whose social sins are to be forgiven, and whose are to be punished, and then the law is compromised. It is no longer coincident with justice. In all likelihood it becomes to a greater or lesser extent the instrument of a class" (Method in Theology, [New York: Seabury Press, 1972] 54). After a brief discussion of how such limitations in the application of justice eventually lead to cultural decline, Lonergan concludes:

Finally, we may note that a religion that promotes self-transcendence to the point, not merely of justice, but of self-sacrificing love, will have a redemptive role in human society inasmuch as such love can undo the mischief of decline and restore the cumulative process of progress (ibid., 55). 
second mile (Matt 5:41), relinquish the right to sue ( 1 Cor $6: 1-7$ ), and even abandon the opportunity to escape unfair imprisonment (Acts $16: 25-34$ ).

4) Rejection of Social Rank and Selfish Ambition

For those who would serve God by serving others there is no room for considerations of social position and rank. The fact that one is assured a place in the coming basileia makes status and class in this age irrelevant. Pursuit of social recognition is rejected out of hand as contrary to God's will. This, of course, has implications for the status of Christian slaves in society as a whole, but it also underlines the basic equality of all christians within the community. As far as the koinonia is concerned, mutual service and respect is to be practised. Attempts to bring worldly considerations of rank to bear within the community are rejected (e.g Mark 10:42-45; Matt 23:1-12; Rom 12:3,16; I Cor 4:6-13; II Cor 10:18; Phi1 2:3; Jas 3:14).10

\section{5)Unifying Motif: Placing One's Interests Last}

The underlying aspect of each of these four elements, love for others, service to the poor, surrender of rights and the rejection of selfish ambition, is the consistent

10 This is not to say that there was no consideration of rank or authority within the church as a whole. Paul, obviously because of pressure from opponents within the community, constantly asserts his authority as an apostle. It is the preoccupation with rank and the seeking after it for selfish reasons rather than for the interests of others that is rejected throughout the New Testament. 
requirement to subordinate one's own interests to those of others. Such self-subordination can be carried out in the confidence that the believer's own interests have already been taken care of by God. The interests of the self may thus be considered secondary to those of the other person. It is evident that the implications of such a requirement-self-abnegation, humility, forebearance and sacrifice--are least onerous for those who have full trust in God to provide and vindicate. Such trust arises from the motives for the servant-ethic.

The Motive to Place One's Interests Last

Although we have identified a consistent call to self-subordination throughout the New Testament writings it is the motives for this ethic and its consistency that makes it characteristic of the early christian self-understanding. These motives number at least four, but again there is one pervasive element that unites them all.

1) Jesus Christ as paradigm

Jesus is seen as paradigmatic for the servant-ethic in the sense that $h$ is ministry and death illustrate the supreme service he practised on behalf of others. Discipleship is the context for the servant-ethic--to follow 
Jesus is to become a servant of others.11 Believers are not to attempt to duplicate Jesus' service exactly, for this is obviously impossible, but they are to look to him for the example of how others are to be served (Matt 20:28; Mark 10:45; Luke 22:27; John 13:15; I Pet 2:21-24). Paul sees such emulation in a particularly astute way and calls upon his readers to practise imitation (E.g., I Thess 1:5-6, $2: 14$; I Cor $4: 16-17 ; 10: 32-11: 1$; Phi1 3:17).

2) The Preservation of Unity

The earliest believers were called to faith in Jesus Christ in community. From the inception of Jesus' religious movement the idea of fellowship, of koinonia, was central. When Paul tells the Corinthian Christians about their counterparts in Macedonia who gave beyond their means willingly and liberally, he is illustrating how the Macedonians' self-understanding as servants of others promotes the unity of the church. Such an act is a manifestation of God's grace ( 11 Cor 8:1), and follows the

11 This does not mean, of course, that the disciples (or the earliest believers) understood themeselves to be equal with Jesus in serving others. His role as a servant is preeminent and can never be emulated completely: "It could never occur to anyone that the way of a disciple was on the same level with that of Jesus. For they had all been taken by him on his way; they all merely shared his way" (Eduard Schweizer, Lordship and Discipleship [London: SCM Press, 1960] 53). 
example of Christ ( 11 Cor 8:9). The Macedonians want to share in the ministry (diakonia) to the saints ( $v .4$ ).12 3) To Ensure the Spread of the Gospel

When Paul speaks of accommodating himself to all in 1 Cor 9:19-23, his stated motive is not to make the situation more comfortable for himself but to ensure that the gospel gets a sympathetic hearing. When Paul says that for the sake of the gospel he becomes all things to all men he illustrates his principle of accommodating the interests, scruples and wishes of others, so far as possible. A similar sentiment is expressed in the Petrine call for wifely submission ( 1 Pet $3: 1-6$ ) in which the motive is not to relieve the awkwardness (or suffering) of women married to unbelievers, but rather to induce the husbands to see the truth of the gospel. For a community whose self-awareness was founded upon the truth that it believed resided in the gospel, it is hardly surprising that sacrifice was called for in order to disseminate the good news as much as possible.13

12 See L.S. Thornton's comments on this passage. He notes that the significance of the contribution was not simply social but "was in harmony with God's will and was a direct product of his grace." It was an illustration of the "essence of koinonia" which involves mutual self-giving. (The Common Life in the Body of Christ [London: Dacre Press, 1963] 27).

13 It is interesting to note that in the synoptic writings this motive is not offered for the servant-ethic. This may well have much to do with the person of Jesus and the transition from the messenger to the message in the 


\section{4) Reward}

The New Testament speaks frankly, as we have seen, of the reward for the believer who practises the servantethic. The self-understanding of the earliest christians was based upon the belief that somehow their self-sacrifice would be vindicated by God, even in the most unjust situations. Those who are prepared to surrender their life will gain it. Those who give liberally store up treasure for themselves. Those who abandon their rights, who do not retaliate, can expect vindication from God. This idea of reward, however, does not proceed from somehow "making a deal" with God. God himself has acted decisively in history through Jesus. Upon the response to this turningpoint, repentance or rejection, hangs the final outcome. The reminders of reward are, in fact, reminders of grace.

\section{5) Unifying Motif: Responding to God's Grace}

It is this awareness of divine grace that permeates the motives offered for the servant-ethic. All the New Testament writers are responding either explicitly (as Paul) or implicitly (as the Gospel writers) to situations within christian communities. These circumstances influence their directives for moral action. Their belief in the death and resurrection of Jesus as salvific and in the future

post-Easter community. One would hesitate, however, to contend that the separation between the two is as wide as some scholars maintain. 
culmination of history as revealing God's glory also impel them. Motivations for moral action reflect these dual beliefs. Often the New Testament writers appeal to the example of Jesus or to the Christian's future reward. The calls to servanthood before others reflect this dual concern.

It is clear, for example, that paul believes that once an individual has become a Christian, the in-dwelling of the spirit causes a moral transformation in the believer's heart (E.g., Gal 5:24-25; Phil 3:7-14). This leads to a corresponding change in one's moral behaviour since, to use Paul's words, it is "no longer I who live, but Christ who lives in me" (aal 3:20). Consequently, the reminders of heavenly reward, the example of Jesus, the promotion of church unity, or the desire to act in certain ways to promote the gospel, are all seen as secondary, in terms of motive, to the natural consequences of becoming a Christian. It is God's will that Christians are mindful of Christ as a paradigm, prevent schisms within their fellowship, and bring the gospel to those who have not heard the good news. More importantly, however, as heirs by grace (Gal 4:7), Christians walk by the spirit and have crucified the flesh (Gal 5:22-26). It is the in-dwelling of the spirit which is the primary impetus for Christian moral 
behaviour.14 Such conduct is marked both by freedom in christ and by its fruit which is, in part, the "love which seeks not its own" (1 Cor 13:5).

Given that it is the indwelling of the Holy spirit (to use Paul's language), or the transformation of metanoia (to echo the synoptic gospel writers), or new birth in the spirit (to iterate John's terms), that leads to the fulfillment of God's will, the motive for the servant-ethic is essentially the desire to respond to God's will, because of the experience of $h$ is love and grace. The freedom achieved in christ inclines the christian to seek the good of the other since there can be no greater selffulfillment.

Limitations upon the Servant-Ethic

1) Questions of Prudence and Common Sense

For the most part, the requirement to serve, to put aside one's own interests is enjoined in the face of

\footnotetext{
14 Modern scholarship in the social sciences has sought to discover whether true altruism is ever displayed in human behaviour. According to many experiments, one would be correct in assuming that no human action is motivated by pure disinterestedness or altruistic concern for the other. Acts which appear to be motivated out of concern for another's suffering are in reality a means to increase one's stature in the eyes of onlookers or to alleviate feelings of guilt, etc. Nevertheless exceptions to this principle seem to have been discovered, which for some scholars offer possibilities by which disciplines such as social psychology can inform and illuminate theology (See, Paul Rigby and Paul $0^{\prime}$ Grady, "Agape and Altruism: Debates in Theology and Social Psychology" JAAR 57 [1989] 719-37).
} 
considerations of prudence and common sense. It is folly, in terms of common sense, to cffer one's left cheek if the right has already been struck. It is certainly imprudent not to seize the opportunity to escape captivity should an earthquake shatter one's fetters. Common sense dictates that one should seek redress for fraud rather than simply revoke one's legal rights. It seems appropriate to respect a compassionate master but unreasonable to honour the demands of a domineering one in a like manner ( 1 Pet 2:18). The servant-ethic does not find its limitations, however, in prudence and common sense.15 The primary limitation is found not in human reason but in God's will. The freedom Christians find in Christ renders questions of prudence, common sense, and even justice subordinate to seeking the will of God in a given situation.16

15 Any ethic grounded in the response to God's grace made known cannot seek its limits in common sense. As Lonergan says:

Common sense commonly feels itself omnicompetent in practical affairs, commonly is blind to long-term consequences of policies and courses of action, commonly is unaware of the admixture of common nonsense in its more cher ished convictions and slogans (Method in Theology, 53).

16 The New Testament, then, is not a call to "situation ethics" in the sense that ethicists such as Joseph Fletcher have advocated (Situation Ethics: The New Morality [Philadelphia: Westminster 1966]). For Fletcher, the aim of all Christian ethical decisions is love. Only love is always good (57-86), and love is the only norm (69-86). While Fletcher's "non-systematic" approach resembles in some ways the ethics of the New Testament, it cannot be said to 
parallel the approach found there because he abandons the principle of seeking God's will and makes the rule of love paramount. What appears to be the action "love" demands in a given situation may, in fact, be at odds with what God requires. As Dodd says:

The foundation of a christian theology, the definition of the nature of God himself, cannot be stated except in ethical terms: "God is love." The thing we have to guard against is the danger of converting that proposition simply and saying, "Love is God," making the ethical primary and subordinating the religious to it (Gospel and Law, 44-45).

This is what Fletcher does. Once love becomes absolute; God is in danger of being relativised. Although others have recognized the context of a situation as important for ethical decision-making, most do not extend this principle to the extreme, as Fletcher does, so that God's will is usurped. Karl Barth illuminates this point when he says:

The command of God must be master, and all historical interpretations and notions, all other considerations, all economic, political, social, cultural and even religious evaluations of the situation must be mastered and not try to play the master. The historical existence and task of his people cannot be an end in itself to a man who hears the command of God. He cannot see it subjected to any ultimate law of its own. He can affirm it only as and because he affirms what God wills from him as one who has a part in this history. He can serve his people only as God will have him do so (Church Dogmatics, I।1.4.296, emphas is mine).

C.H. Dodd also invokes the reality of Christian experience as constitutive for ethical-decision making in the thought of Paul. Citing Rom 12:2; Phil 1:10 and Eph 5:10,17, he says:

What Paul expects of the free man who is "servant of Jesus Christ" is a clear and independent insight into moral values. The christian if he has truly entered into the new life, is able to "ascertain by experience what 
2) The Primary Limitation--Violating God's Will

All ethical exhortation in the New Testament is grounded in the will of God. How one determines the will of God depends not upon prudence or common sense but rather upon the very experience of his grace. In some places conscience is also used as a means of determining ethical boundaries or limitations. Paul is the biggest champion of this term but it is found also in the pastoral epistles, I Peter and Hebrews.17 To refrain from violating or opposing God's will is the only ostensible limitation placed upon the servant-ethic in the New Testament. The only time a believer should not place his or her interests last is in circumstances that would constitute resistance to God's will. Essentially the servant-ethic is without limitations. The self-awareness of the believer as servant of God and others by grace imparts a sense of freedom to Christian conduct as expressed in the New Testament. The

is the will of God" and to judge for himself what kind of conduct conforms to that will ("The Ethics of the Pauline Epistles," 297).

Dodd (among others) also believes that a catechism of ethical instruction developed very early in Christian history and traces of (or even excerpts from) it are detectable in the New Testament. This catechism was a "scheme of practical precepts for everyday living" (Gospel and Law, 25 ).

17 See W.D. Daries, "Conscience and 1 ts Use in the New Testament," 254-56. Davies notes that in the non-Pauline epistles it is noteworthy that conscience and faith are tied together despite the claims that the Pastorals (especially) promote a "bourgeois morality." 
inner transformation that occurs in response to divine grace is manifested as freedom--the freedom to serve.

\section{The Freedom to Serve}

The idea of Christian freedom is the key to the servant-ethic in the New Testament. As Schlier says in his article on eleutheros:

$$
\begin{aligned}
& \text { By the spirit and power of the life of Jesus } \\
& \text { Christ radically offered up in love there is } \\
& \text { brought into being in our lives an existence } \\
& \text { which is unselfish and self-forgetting because } \\
& \text { it is dynamically hidden in love and can no } \\
& \text { longer be self-seeking or self-willed. In the } \\
& \text { spirit of the freedom of Jesus Christ, there } \\
& \text { arises our freedom.18 }
\end{aligned}
$$

For Luther the freedom found in Christ leads to joyful service of others. He asserts, "A Christian is a perfectly free lord, subject to none. A Christian is a perfectly dutiful servant of all, subject to all."19 This is a paradox which arises directly from the christian belief in the crucifixion and resurrection of Jesus. For the New Testament writers this act of God in history has broken the bonds which enslaved human beings and offered them true freedom (e.g., Gal 4:8-9). At the same time, however, the spontaneous response to this act of grace is to seek the good of others rather than oneself. Paul represents this paradox most clearly (Gal 5:13), although it is also found

18 TDNT $11,499$.

19 "The Freedom of a Christian," 344. 
in the gospels and other New Testament writings. In the synoptic gospels the acceptance of discipleship implies a liberation from concerns about the self in that true discipleship requires the willingness to lay down one's life (Mark 8:38). Personal ambition is incompatible with such a decision, for "the son of man came not to be served but to serve," and his behaviour is paradigmatic for his disciples. This aspect of Jesus' self-understanding, as depicted in the gospels, implies a movement to break free from concerns about prestige, social status or personal gain. The true disciple is "other-directed." such freedom is only authentic, then, if it is freedom from self.

The self and the other and the New Testament Servant-Ethic

The words of Jesus and the writings of Paul early on became normative as guides for ethical reflection in the early Christian communities, but the primary principles for moral action were derived from the experience of God's love as manifested in Christ. Modern Christian ethicists continue to seek the answer to how the Christian should go about acting ethically, but most agree that love is one principle that needs to be discerned and applied if ethics are to be Christian. This love is applied when others are served. The New Testament idea of freedom in Christ demands that christians meet the needs and act in the interest of others. The New Testament in all its diversity consistently 
reflects this requirement, even if it is not systematic in describing how one should go about this.

The preceding pages have attempted to delineate that the servant-ethic is a consistent and unifying characteristic of the earliest Christians' selfunderstanding. It consists of self-subordination in response to the grace of God. It is the manifestation of God's grace and is limited only by his will. The other is the one who is in need or the one who enjoys abundance. He is a friend or he is the enemy. She participates in the community of Christ or she rejects the truth of the Gospel. The existence of the other is somehow constitutive for defining the self. The servant-ethic emphasizes the responsibility of the Christian to the other that goes beyond mutuality and reciprocity and makes the interests of the other paramount. 20

20 Thomas Ogletree pursues the question of the other in his essay subtitled "The Role of the "Other" in Moral Experience." Ogletree points out that Western ethics is "self-centred" in the sense that its

dominant tendency... has been to accent the self-constitution of ego, the moral actor, in establishing the possibilities for criticism and innovation in moral experience. The "other" takes on significance largely because of the essential role he or she plays in the process. The moral interests of the other are not overlooked. Yet they derive their force primarily from the moral actor's own identification with other and his projection of his own sense of moral worth on that other (Hospitality to the stranger, 39). 
Ever since the ancient Greeks inscribed gnothi seauton at Delphi, it seems that the aim and goal of human endeavour, at least in the West, has been the quest for self-understanding. Such a quest is carried out in the community of others; however, it is a community in which the alienation of the self is a perennial dilemma. It is only in the encounter with others that the self can become human.21 Christian ethical reflection, whether it arises

21 Lonergan claims:

Just as it is one's own self-transcendence

that enables one to know others accurately and to judge them fairly, so inversely it is through knowledge and appreciation of others that we come to know ourselves and to fill out and refine our apprehension of values (Method in Theology, 253).

Lonergan speaks in a context of attempting to overcome conflict through dialectic. On a more basic level the encounter with another person, in every instance, brings greater self-knowledge and also opportunities to serve. It is my belief that some of the more accessible work of the Jewish philosopher Emmanuel Levinas captures the spirit of the New Testament servant-ethic in a way that many contemporary Christian ethicists fail to do. For example, Levinas says:

I am responsible for the other without waiting for his reciprocity, were 1 to die for it. Reciprocity is his affair. It is precisely insofar as the relationship between the other and me is not reciprocal that 1 am [in] subjection to the other (Ethics and Infinity [Pittsburgh: Duquesne University Press, 1985] 98).

and:

I have previously said... that I am responsible for the persecutions that 1 undergo. But only me! My "close relations" or "my people" are 
from the earliest communities or contemporary theologians, demands that the other, the neighbour, even the enemy, is to be served simply because he or she is there.22 God's will, in and of itself, effectively abrogates any other principle

already the others and, for them, I demand justice.... al am responsible even for the other's responsibility (1bid., 99).

Finally, for Levinas, the other makes absolute claims upon the self that can only be responded to by selftransformation:

To recognize the other is to recognize a hunger. To recognize the other is to give. But it is to give to the master, to the lord, to him whom one approaches as "You" ["Vous"] in a dimension of height (Totality and Infinity [Pittsburgh: Duquesne University Press, 1969] 75).

In a sense the self becomes a servant of the other, especially since Levinas sees freedom contingent upon the other. Only the other who, in a sense, limits my freedom, can also justify it. Thomas ogletree comments that Levinas' work "is likely to be irresistible to those nurtured in Biblical faith" because of "the infinite enlargement of responsibility" found therein. Ogletree says, however, that Levinas' call for self-sacrifice before the other need not be in fundamental contradiction to egoistic satisfaction. He says that the freedom of self "always embraces the possibility that moral sacrifice, rather than negating egoistic enjoyment, will transfigure and ennoble it--that life will be discovered and embraced in the power to give it up for the sake of the other" (Hospitality to the stranger. 56 ).

22 The neighbour as representative of God or Christ is thematic in the New Testament, especially the synoptic gospels (Mark 9:37, par; Matt 25:31-46). Ernst Kasemann applies this with in the context of the church. He notes that humility (tapeinophrosyne) must be practised in the presence of Christ "even when--indeed precisely when-encounter this presence embodied in the person of my brother who has also his charisma" ("Ministry and Community in the New Testament," in Essays on New Testament Themes [London: SCM Press, 1964] 80). 
for ethics on the part of those who seek to fulfill his will. For the New Testament writers gnöthi seauton was important, but gnōthi theon was paramount. The work of Christ and the subsequent continuation of that work through serving others both fulfilled God's will and revealed his just, merciful and loving nature in human encounters. This was the freedom the early Christians believed was achieved in Christ--the freedom to serve because of the manifestation of God's grace. "Wherever one person regards another more highly than self and is concerned to be of service to the other person, there God's will is done and the law of Christ is fulfilled."23 That the New Testament is diverse in matters theological has become a truism amongst biblical scholars. Early christian writers differ on the idea of agape, for example, which is an idea considered by many to be central in the New Testament. While the synoptic gospels insist on universal expression of agapé, the Johannine writings tend to limit it to the Christian fellowship. Within the Pauline writings the undisputed epistles also understand love as especially important for the Christian life, while the Pastoral epistles tend to reduce agape to one virtue among many and thereby diminish its distinctive nature. Almost all of the writers of the New Testament, however, whatever their differences in their 
expressions of kerygma and ethics, seem to agree that the Christian life is one of self-subordination and service to others. Pursuit of personal interests, selfish ambition and self-assertion are to be replaced by "other-directedness" and "self-forgetfulness." Belief in the son of Man who came "not to be served but to serve," requires that the christian also serve. This servant-ethic is a fundamental characteristic of the christian life as it is presented in the New Testament. It permeates this early collection of Christian writings and is emblematic, therefore, of the earliest phase of Christian ethical thought. 


\section{BIBLIOGRAPHY}

(Texts cited)

Adamson, James B. James: the Man and his Message. Grand Rapids: William B. Eerdmans Publishing Co., 1989.

Albright, W.F. and C.S. Mann. Matthew. Garden City, New York: Doubleday and Co., 1971.

Allen, Joseph L. Love and Conflict: A Covenantal Mode of Christian Ethics. Nashville: Abingdon Press, 1984.

Aristotle. Nichomachean Ethics. Translated by H. Rackham. LCL, 1962 .

Attridge, Harold $w$. The Epist le to the Hebrews.

Philadelphia: Fortress Press, 1989.

Balch, David. Let Wives be Submissive: The Domestic Code in 1 Peter. At lanta: Scholars Press, 1981.

Banks, Robert. Paul's I dea of Community. Exeter: The Paternoster Press, 1980.

Barclay, John M.G. "Paul, Philemon and Christian SlaveOwnership" in NTS 37 (1991) 161-186.

Barrett, C.K. A Commentary on the Epistle to the Romans London: Adam and Charles Black, 1957.

Barrett, C.K. The First Epistle to the Corinthians (second edition). London: Adam and Charles Black, 1971.

Barrett, C.K. Freedom and obligation: A study of the Epistle to the Galatians. London: SPCK, 1985.

Barrett, C.K. The Gospel According to John (second edition). Philadelphia: Westminster Press, 1978.

Barrett, C.K. The Pastoral Epistles. Oxford: Clarendon Press, 1963.

Barrett, C.K. The Second Epistle to the Corinthians. London: Adam and Charles Black, 1973. 
Barrett, C.K. "Things Sacrificed to Idols" in Essays on Paul, 40-59. Philadelphia: The Westminster Press, 1982 .

Bartchy, S. Scott. First Century slavery and I Corinthians 7:21. Atlanta: Scholars Press, 1971.

Barth, Kar 1. Church Dogmatics $1 / 1 / 4$. Translated by A.T. Mackay et a1. Edinburgh: T. and T. Clark, 1961.

Bassler, Jouette M. Divine Impartiality. Chico: Scholars Press, 1982 .

Beare, F.W. A Commentary on the Epistle to the Philippians. New York: Harper and Brothers, 1959.

Beare, F.W. The First Epistle of Peter. Oxford: Basil Blackwell, 1961.

Beare, Francis Wright. A Commentary on the Epist le to the Philipoians (second edition). London: Adam and Charles Black, 1959.

Beare, Francis Wright. The Gospel According to Matthew. Oxford: Basil Blackwell, 1981.

Bernard, J.H. The Gospel According to st. John 11 . Edinburgh: T. and T. Clark, 1928 .

Best, Ernest. Following Jesus: Discipleship in the Gospel of Mark. Sheffield: JSOT, 1981.

Betz, Hans Dieter, "Cosmogony and Ethics in the Sermon on the Mount" in Essays on the Sermon on the Mount 89123. Translated by L.L. Welborn. Philadelphia:

Fortress Press, 1985.

Betz, Hans Dieter. Galatians. Philadelphia: Fortress Press, 1979.

Beyer, H.W. "Diakoneo, diakonia, diakonos," TDNT $\mid 1$ 81-93.

Boismard, M-E. "Le Lavement de Pieds," RB 71 (1964) 524.

Bornkamm, Gunther. Jesus of Nazareth. Translated by Irene and Fraser McLuskey. New York: Harper and Row, 1975 . 
Bornkamm, Gunther. "On Understanding the Christ-Hymn" in Early Christian Experience 112-122. Translated by Paul L. Hammer. New York: Harper and Row, 1969.

Bornkamm, Gunther. Paul. Translated by M.G. Stalker. New York: Harper and Row, 1971.

Boulton, P.H. "Diakoneō and its Cognates in the Four Gospels" SE I, 415-22. Edited by K. Aland et al., Berlin: 1959 .

Brown, Raymond E. The Epistles of John. New York: Doubleday and Co., 1982.

Brown, Raymond E. The Gospel According to John $1-x \mid 1$. New York: Doubleday and Co., 1970.

Brown, Raymond E. The Gospel According to John $x|||-x| x_{1}$. New York: Doubleday and Co., 1970.

Bruce, F.F. and Simpson, E.K. Commentary on the Epist les to the Ephesians and the Colossians. Grand Rapids : William B. Eerdmans Publishing Co., 1957.

Bruce, F.F. The Epistle to the Galatians. Grand Rapids: William B. Eerdmans Publishing Co., 1982.

Bruce, F.F. The Epistles of John. Grand Rapids: William B. Eerdmans Publishing Co., 1970.

Brunner, Emil. The Divine Imperative: A study in Christian Ethics. Translated by olive Wyon. London: The Lutterworth Press, 1937.

Bultmann, R. The Johannine Epistles. Translated by $R$. Philip O'Hara. Philadelphia: Fortress Press, 1973.

Bultmann, R. The Gospel of John. Translated by G. R. Beasley-Murray. Philadelphia: Westminster Press, 1971 .

Bultmann, R. Jesus and the Word. Translated by Louise Pettibone Smith and Ermine Huntress Lantero. New York: Charles Scribner's Sons, 1958.

Burchard, Christoph. "The Theme of the Sermon on the Mount," in Essays on the Love Commandment. Trans lated by Reginald $H$. and lise Fuller. 57-91. Philadelphia: Fortress Press, 1978. 
Burton, Ernest De witt. A Critical and Exegetical Commentary on the Epistle to the Galatians.

Edinburgh: T. and T. Clark, 1921.

Cambel1, R. Alistair. "Does Paul Acquiesce in Divisions at the Lord's Supper?" NovT 33 (1991) 61-70.

Carson, David. "Pauline Inconsistency: Reflections on 1 Corinthians $9.19-23$ and Galatians $2.11-14$ " Churchman $100(1986)$ 7-45.

Chilton, Bruce and McDonald, J.I.H. Jesus and the Ethics of the Kingdom. Grand Rapids: William B. Eerdmans Publishing Co., 1987.

Conzelmann, Hans. Acts. Translated by J. Limburg, A.T. Kraabel, D.H. Juel. Philadelphia: Fortress Press, 1983.

Cranfield, C.E.B. The Epistle to the Romans 1. Edinburgh: $T$. and T. Clark Ltd., 1975.

Cranfield, C.E.B. The Epistle to the Romans 11 . Edinburgh: T. and T. Clark Ltd., 1979.

Daube, D. The New Testament and Rabbinic Judaism. London: Athlone, 1956.

Davids, Peter $H$. The Epistle of James. Grand Rapids: William B. Eerdmans Publishing Co., 1982.

Davids, Peter H. The First Epistle of Saint Peter. Grand Rapids: William B. Eerdmans Publishing Co., 1990.

Davies, W.D. "Conscience and its use in the NT" Jewish and Pauline Studies, 243-256. Philadelphia: Fortress Press, 1984.

Davies, W.D. and Allison, Dale C. The Gospel according to Saint Matthew I. Edinburgh: T. and T. Clark, 1988.

Davies, W. D. and Allison, Dale C. The Gospel according to Saint Matthew II. Edinburgh: $T$ and $T$ Clark, 1991.

Davies, W.D. Invitation to the New Testament. Garden city, New York: Doubleday and Co., 1969.

Davies, W.,D. "The Moral Teaching of the Early Church" Jewish and Pauline Studies, 278-288. London: SPCK, 1984 . 
Davies, W.D. Paul and Rabbinic Judaism. London: SPCK, 1955 .

Davies, W.D. The setting of the sermon on the Mount. Atlanta: Scholars Press, 1989.

De Boer, W.P. The Imitation of Paul: An Exegetical study. Kampen: J.H. Kok, 1962 .

Delcor, Mathias. Le Testament d'Abraham. Leiden: E.J. Brill, 1973.

Dibelius, Martin. James. Translated by Michael A. Williams. Philadelphia: Fortress Press, 1976.

Dibelius, Martin and Conzelmann, Hans. The Pastoral Epistles. Translated by Philip Buttolph and Adela Yarbro. Philadelphia: Fortress Press, 1972.

Dihle, A. "Demut" RAC $111,735-78$.

Dodd, C.H. "The Ethics of the Pauline Epistles" The Evolution of Ethics. Edited by E. Hershey Sneath. New Haven: Yale University Press, 1957.

Dodd, C.H. Gospel and Law. New York: Columbia University Press, 1951.

Dodd, C.H. Historical Tradition in the Fourth Gospel. Cambridge: Cambridge University Press, 1965.

Dunn, James G. Unity and Diversity in the New Testament (second edition). Philadelphia: Trinity Press International, 1990.

Dunn, James D.G. "The Washing of the Disciples' Feet in John 13:1-20" ZNW 61 (1970) 247-52.

Elliott, John H. "I Peter, its situation and Strategy," in Perspectives on First Peter, 61-78. Edited by Charles H.Talbert. Macon, Georgia: 1986.

Ellu1, Jacques. The Ethics of Freedom. Translated by Geoffrey W. Bromiley. Grand Rapids: William B. Eerdmans Publishing Co., 1976.

Engberg-Pedersen, Troels. "I Corinthians 11:16 and the Character of Pauline Exhortation" JBL 110 (1991) 679-689. 
Enslin, Morton Scott. The Ethics of Paul. New York: Abingdon Press, 1957.

Epictetus. The Discourses 1 and II. Translated by W.A. Oldfather. LCL, 1966, 1967.

Epstein, 1., editor. The Babylonian Talmud. London: Soncino Press, 1938.

Fiorenza, Elisabeth Schussler. In Memory of Her. New York: Crossroad, 1984.

Fitzmyer, Joseph A. The Gospel according to Luke $1-1 X$. Garden City, New York: Doubleday and Co., 1981.

Fitzmyer, Joseph A. The Gospel according to Luke X-XXIV. Garden City New York: Doubleday and Co., 1981.

Flescher, Paul V. Oxen, Women, or Citizens? slaves in the system of the Mishnah. At lanta: Scholars Press, 1988 .

Fletcher, Joseph. Situation Ethics: The New Morality. Philadelphia: The Westminster Press, 1966.

Fow 1, stephen E. The story of Christ in the Ethics of Paul. Sheffield: Sheffield Academic Press, 1990.

Fox-Genovese, Elizabeth, and Genovese, Eugene D. "The Divine Sanction of Social Order: Religious Foundations of the Southern slaveholders' World View" JAAR 55 (1987) 211-33.

Francis, Fred 0 . "Humility and Angelic Worship in Col 2:18," in Conflict at Colossae. Edited by Fred 0 . Francis and Wayne A. Meeks. Cambridge Massachusetts: Scholars Press, 1975.

Friedlander, G. Jewish Sources of the sermon on the Mount. New York: Ktar Publishing House, 1969.

Funk, Robert W. Parables and Presence. Philadelphia: Fortress Press, 1982.

Furnish, Victor Paul. The Love Command in the New Testament. New York: Abingdon Press, 1972.

Furnish, Victor Paul. Theology and Ethics in Paul. Nashville: Abingdon Press, 1968. 
Gardner, E.C. Biblical Faith and Social Ethics. New York: Harper and Row, 1960.

Gerhardsson, Birger. The Ethos of the Bible. Translated by Stephen Westerholm. Philadelphia: Fortress Press, 1981 .

Gerhardsson, Birger. "Sacrificial Service and Atonement in the Gospel of Matthew" in Reconciliation and Hope, 25-35. Edited by Robert Banks. Grand Rapids: William B. Eerdmans Publishing Co., 1974.

Gnilka, Joachim. Das Evangelium nach Markus 11. Zürich, Einsiedeln, Köln: Benziger Verlag, 1979.

Gooch, Paul W. and Richardson, Peter. "Accomodation Ethics" TynBul 29 (1978) 89-142.

Gooch, Paul W. "Conscience in 1 Corinthians 8 and 10," NTS, $33(1987), 224-254$.

Goppelt, L. Theology of the New Testament 1 and 11 . Translated by John E. Alsup. Grand Rapids: William B. Eerdmans Publishing Co., 1982.

Grundmann, W. "tapeinos" TDNT VI11, 1-26.

Gustafson, James. Can Ethics Be Christian? Chicago: University of Chicago, 1975.

Gustafson, James M. "Moral Discernment in the Christian Life" in Norm and Context in Christian Ethics, 17-36. Edited by Gene H. Outka and Paul Ramsey. New York: Charles Scribner's Sons, 1968.

Gutierrez, Gustavo, A Theology of Liberation, Translated by Sister Caridad Inda and John Eagleson. Maryknoll, New York: Orbis Books, 1988.

Hallett, Garth. Christian Neighbor-Love. Washington D.C.: Georgetown University Press, 1989.

Hanson, A.T. The Pastoral Epistles. Grand Rapids: William B. Eerdmans Publishing Co., 1982.

Hauerwas, Stanley. The Peaceable Kingdom. Notre Dame: University of Notre Dame Press, 1983.

Hays, Richard B. "Christology and Ethics in Galatians: The Law of Christ," CBQ 49 (1987) 268-290. 
Henge 1, Martin. The Charismatic Leader and his Followers. Translated by James C.G. Greig. Edinburgh: T. and T. Clark, 1981 .

Héring, Jean. The Epistle to the Hebrews. Translated by A.W. Heathcote and P.J. Allcock. London: Epworth Press, 1970.

Hooker, Morna D. "Interchange in Christ and Ethics" From Adam to Christ: Essays on Paul, 56-69. Cambridge: Cambridge University Press, 1990.

Hooker, Morna D. "Philippians 2:6-11" From Adam to Christ: Essays on Paul, 88-100. Cambridge: Cambridge University Press, 1990.

Horsley, Richard A. "Consciousness and Freedom among the Corinthians: I Cor 8-10," CBQ 40 (1978) 574-589.

Hultgren, Arland J. "The Johannine Footwashing (13, 1-11) as a Symbol of Eschatological Hospitality" NTS 28 539-546.

Hurtado, L. W. "Jesus as Lordly Example in Philippians 2:511" From Jesus to Paul: Studies in Honour of Francis Wright Beare, 113-26. Edited by Peter Richardson and John C. Hurd. Water loo: Wilfrid Laurier University Press, 1984.

Jeremias, Joachim. New Testament Theology. Translated by John Bowden. London: SCM Press, 1971.

Jeremias, Joachim. "Die Salbüngsgeschichte Mk 14:3-9" Abba, 107-120. Göttingen: Vandenhoeck and Ruprecht, 1966 .

Johnson, Luke T. The Literary Function of Possessions in Luke-Acts. Chico: Scholars Press, 1977.

Käsemann, Ernst. A Commentary on Romans. London: SCM Press, 1980 .

Käsemann, Ernst. "Ministry and Community in the New Testament" in Essays on New Testament Themes, 63-94. Translated by W.J. Montague. London: SCM Press, 1964.

Keck, Leander E. Paul and His Letters. Philadelphia: Fortress Press, 1979. 
Kee, Howard Clark. Jesus in History: An Approach to the study of the Gospels (second edition). New York: Harcourt Brace Jovanovich, Inc., 1977.

Kelly, J.N.D. A Commentary on the Pastoral Epistles. London: Adam and Char les Black, 1963.

Kenda11, David W. "The Literary and Theological Function of 1 Peter 1:3-12" Perspectives on First Peter, 103120. Edited by Charles H. Talbert. Macon, Georgia: Mercer University Press, 1986.

Kierkegaard, S. Works of Love. Translated by Howard and Edna Hong. New York: Harper Torchbooks, 1962.

Klassen, William. Love of Enemies: The Way to Peace. Philadelphia: Fortress Press, 1984.

Klausner, Joseph. Jesus of Nazareth. Translated by Herbert Danby. New York: Menorah Publishing Co., 1925.

Knox, John. chapters in a Life of Paul. New York: Abingdon Press, 1950.

Knox, John. The Ethics of Jesus in the Teaching of the Church. New York: Abingdon Press, 1961.

Knox, W.L. "John 13:1-30" HTR 43 (1950) 161-63.

Kötting, B. "Fússwaschung," in RAC VIII, 743-59.

Lagrange, Le P. M.-J. Evangile selon Saint Mark. Paris: Libraire Lecoffre, 1966.

Lane, William L. The Gospel According to Mark. Grand Rapids: William B. Eerdmans Publishing Co., 1974.

Lemcio, Eugene E. "The Unifying Kerygma of the New Testament," JSNT 33 (1988) 3-17.

Levinas, Emmanuel. Ethics and Infinity. Translated by Richard A. Cohen. Pitssburgh: Duquesne University Press, 1985.

Levinas, Emmanue1. Totality and Infinity. Translated by Aphonso Lingis. Pittsburgh: Duquesne University Press, 1969.

Lillie, william, "The Christian Conception of self-Denial" in studies in New Testament Ethics, 151-162.

Edinburgh and London: Oliver and Boyd, 1961. 
Lindars, Barnabas. The Gospel of John. London: 01 iphants, 1972 .

Lindars, Barnabas. The Theology of the Letter to the Hebrews. Cambridge: Cambridge University Press, 1991.

Lohfink, Gerard. Jesus and Community. Translated by John P. Galvin. Philadelphia: Fortress Press, 1984.

Lohse, Eduard. Theological Ethics of the New Testament. Minneapolis: Fortress Press, 1991.

Lonergan, Bernard. Method in Theology. New York: The Seabury Press, 1972.

Longenecker, Richard N. Paul: Apostle of Liberty. Grand Rapids, Michigan: Baker Book House, 1976.

Lull, David, J. "The Servant-Benefactor as a Model of Greatness (Luke 22:24-30)" NovT 28 (1986) 289305 .

Luther, Martin. "A Treatise on Christian Liberty" in Luther's Works, 31, 327-77. Translated by W.A. Lambert. Philadelphia: Muhlenberg Press, 1957.

Luz, Ulrich. Matthew 1-7. Minneapolis: Augsburg Fortress, 1989.

Lyonnet, S. "Christian Freedom and the Law of the Spirit According to saint Paul" in The Christian Lives by the Spirit, 145-74. New York: Alba House, 1971.

Malherbe, Abraham J. Social Aspects of Early Christianity (second edition). Philadelphia: Fortress Press, 1983 .

Mann, C.S. Mark. Garden City, New York: Doubleday and Co., 1986 .

Manson, T.W. The Sayings of Jesus. London: SCM Press, 1949.

Marcus Aurelius Antonius. Speeches and Sayings. Translated by C.R. Haines. LCL, 1961.

Marshall, L.H. The Challenge of New Testament Ethics. London: Macmillan and Co., 1946. 
Martens, Jo-Ann. "Paul ine Mimesis: The Realization of an Ethic." M.A. thesis, McMaster University, 1986.

Martin, clarice J. "Womanist Interpretations of the New Testament: The Quest for Holistic and Inclusive Translation and Interpretation" JFSR (1990) 41-61.

Martin, Dale B. Slavery as Salvation. New Haven: Yale University Press, 1990.

Martin, Ralph P. Carmen Christi: Philippians ii. 5-11 in Recent Interpretation and in the setting of Early Christian Worship. Cambridge University Press: 1967 .

Martin, Ralph P. Colossians: The Church's Lord and the Christian's Liberty. Exeter, Devon: Paternoster Press, 1972 .

Martin, Ralph P. Philippians. London: Oliphants, 1976.

Mathews, Shailer. Jesus on Social Institutions. Edited by Kenneth Cauthen. Philadelphia: Fortress Press, 1971 .

Meeks, Wayne A. The First Urban Christians. New Haven: Yale University Press, 1983.

Meeks, Wayne A. The Moral World of the First Christians. Philadelphia: Westminster Press, 1986.

Meeks, Wayne A. The Writings of st. Paul. New York: W.W. Norton and Co. 1972.

Meyer, Ben F. The Aims of Jesus. London: SCM Press, 1979 .

Meyer, Ben F. The Early Christians: Their World Mission and Self-Discovery. Wilmington, Delaware: Michael Glazier Inc., 1986 .

Mitton, C.L. The Epistle to the Ephesians. London: Oliphants, 1962 .

Mitton, C.L. The Epistle of James. London: Marshall, Morgan and scott, 1966 .

Montefiore, C.G. The Synoptic Gospels 1 and $\mid 1$. London: Macmillan and Co., 1927. 
Montefiore, H.W. A Commentary on the Ep ist le to the

Hebrews. London: Adam and Charles Black, 1964.

Morris, Leon. The Gospel According to John. London: Marsha 11, Morgan and Scott, 1971.

Mott, Stephen, Biblical Ethics and Social Change. New York: Oxford University Press, 1982.

Moule, C.F.D. The Epistles of Paul the Apostle to the Colossians and to Philemon. Cambridge: Cambridge University Press, 1968.

Müssner, Franz. Theologie der Freiheit nach Paulus. Freiburg: Herder, 1976.

Niebuhr, Reinhold. An Interpretation of Christian Ethics. New York: Meridian Books, 1956.

Niebuhr, Reinhold. Love and Justice. Philadelphia: Wesminster Press, 1957.

Nygren, Anders. Agapé and Eros. Translated by Philip s. Watson. Chicago: University of Chicago Press, 1953.

Ogletree, Thomas $w$. Hospitality to the stranger.

Philadelphia: Fortress Press, 1985.

Ogletree, Thomas $w$. The Use of the Bible in christian Ethics. Oxford: Basil Blackwell, 1983.

Osborn, Eric Francis. Ethical Patterns in Early Christian Thought. Cambridge: Cambridge University Press, 1976 .

Outka, Gene. Agapé: An Ethical Analysis. New Haven: Yale University Press, 1972.

Outka, Gene H. "Character, Conduct, and the Love Commandment" Norm and Context in Christian Ethics, 37-65. Edited by Gene H. Outka and Paul Ramsey. New York: Charles Scribner's Sons, 1968.

Outka, Gene. "On Harming Others" Int 34 (1980) 381-93.

Perkins, Pheme. "Paul and Ethics" Int 38 (1984) 268-280.

Philo, "The Contemplative Life" IX. Translated by F.H. colson. LCL, 1967 . 
Philo, "Every Good Man is Free" IX. Translated by F.H. Colson. LCL, 1967.

Philonenko, Marc. Joseph et Asénath. Leiden: E.J. Brill, 1968 .

Pieper, Josef. Justice. Translated by Lawrence Lynch. New York: Pantheon Books, 1955.

Pieper, Josef. Prudence. Translated by Lawrence Lynch. New York: Pantheon Books, 1959.

Piper, John. Love Your Enemies: Jesus' Love Command in the synoptic Gospels and in the Early Christian Paranesis. Cambridge: Cambridge University Press, 1979 .

Post, stephen G. "The Inadequacy of Selflessness: God's suffering and the Theory of Love," JAAR 56 (1988) 213-228.

Post, Stephen G. A Theory of Agape. Lewisburg: Bucknell University Press, 1990.

Reinhartz, A. "On the Meaning of the Pauline Exhortation: "mimétai mou ginēsthe--become imitators of me," SR 16 (1987) 393-403.

Rengstorf, K.H. "Doulos" TDNT II, 261-280.

Reumann, John. Variety and Unity in New Testament Thought. Oxford: Oxford University Press, 1991.

Richardson, Peter. "Pauline Inconsistency: 1 Corinthians 9:19-23 and Galatians $2: 11-14 "$ NTS 26 347-362.

Richardson, Peter. Paul's Ethic of Freedom. Philadelphia: The Westminster Press, 1979.

Rigby, Paul and $O^{\prime}$ Grady, Paul. "Agape and Altruism: Debates in Theology and Social Psychology," JAAR 57 (1989) $719-737$.

Robertson, Archibald and Plummer, Alfred. A Critical and Exegetical Commentary on the First Epistle of st. Paul to the Corinthians. Edinburgh: T. \& T. Clark, 1914.

Sampley, J. Paul. Pauline Partnership in Christ.

Philadelphia: Fortress Press, 1980. 
Sampley, J.Paul. Paul's Moral Reasoning: Walking Between the Times. Minneapolis: Fortress Press, 1991.

Sanders, E.P. Paul, the Law, and the Jewish People. Philadelphia: Fortress Press, 1983.

Sanders, Jack T. Ethics in the New Testament. Philadelphia: Fortress Press, 1975.

Schlier, Heinrich. "Eleutheros" TDNT 11, 487-502.

Schnackenburg, Rudolf. The Moral Teaching of the New Testament. Translated by J. Holland-smith and W.J. OHara. London: Burns and Oates, 1975.

Schottroff, Luise. "Non-violence and the Love of One's Enemies," Essays on the Love Commandment, 9-39. Translated by Reginald $H$. and I ise Fuller. Philadelphia: Fortress Press, 1978.

Schrage, Wolfgang, The Ethics of the New Testament. Translated by David E. Green. Philadelphia: Fortress Press, 1988 .

Schweizer, Eduard. The Letter to the colossians.

Minneapolis: Augsburg Publishing House, 1982.

Schweizer, Eduard. Lordship and Discipleship. London: SCM Press, 1960 .

Segovia, Fernando, F. "John 13:1-20, The Footwashing in the Johannine Tradition" ZNW 73 (1982) 31-51.

Segovia, Fernando $F$. Love Relationships in the Johannine Iradition. Chico: Scholars Press, 1982.

Selwyn, E.G. The First Epistle of st Peter. London: Macmilian and Co., 1964.

Shaw, George Bernard. "The Monstrous Imposition upon Jesus" The Writings of Saint Paul, 296-302. Edited by Wayne A. Meeks. New York: W.W. Norton and Co., 1972 .

Shaw, Graham. The Ccost of Authority: Manipulation and Freedom in the New Tstament. Philadelphia: Fortress Press, 1982.

Smalley, Stephen. John--Evangelist and Interpreter. Greenwood, S.C.: Attic Press, 1983. 
Spicq, C. Agape in the New Testament 1. Translated by Sister Marie Aquinas McNamara and Sister Mary Honoria Richter. St Louis: B. Herder Book Co., 1963.

Stauffer, E. "Agapaaō" TDNT 1, 21-55.

Stendah 1, Krister. "Hate, Nonretaliation and Love: Coals of Fire" Meanings, 137-149. Philadelphia: Fortress Press, 1984.

Stendah 1, Krister. Paul Among Jews and Gentiles.. Philadelphia: Fortress Press, 1976.

Stob, Henry. Ethical Reflections: Essays on Moral Themes. Grand Rapids: William B. Eerdmans Publishing Co., 1978 .

Stuhlmacher, P. Reconciliation, Law, and Righteousness. Translated by E.R. Kalin. Philadelphia: Fortress Press, 1986.

Swartley, Willard M. Slavery, Sabbath, War, and Women. Kitchener, Ontario: Herald Press, 1983.

Tamez, Elsa. The Scandalous Message of James. New York: crossroad, 1990.

Taylor, Vincent. The Gospel according to Mark. London: Macmillan and Co., 1953.

Thieme, K. Die christliche Demut. Giezen: Alfred Topelmann, 1906.

Thomas, John Christopher. Footwashing in John 13 and the Johannine Community. Sheffield: Sheffield Academic Press, 1991.

Thomas, George F. Christian Ethics and Moral Philosophy. New York: Charles Scribner's Sons, 1955.

Thompson, Marianne Meye. The Humanity of Jesus in the Fourth Gospel. Philadelphia: Fortress Press, 1988.

Thornton, L.S. The Common Life in the Body of Christ (fourth edition). London: Dacre Press, 1963.

Tillich, Paul. Morality and Beyond. New York: Harper and Row, 1963 . 
Urbach, E.E. "The Laws Regarding Slavery as a Source for Social History of the Period of the Second Temple, the Mishnah and Talmud" Papers of the Institute of Jewish Studies. London, I. Edited by J.G. Weiss. Jerusalem: Magnes Press, 1964.

Verhey, Allen. The Great Reversal. Grand Rapids: william B. Eerdmans Publishing Co., 1984.

Via, Dan O. Jr. The Ethics of Mark's Gospel: In the Middle of Time. Philadelphia: Fortress Press, 1985.

Wanamaker, C. A. "Philippians 2:6-11: Son of God or Adamic Chr istology?" NTS 33 (1987) 179-193.

Webster, John. "Christology, Imitability and Ethics" SJT 39 (1986) 309-326.

Weiss, Herold. "Foot Washing in the Johannine Community," NovT 21 (1979) 298-325.

Wengst, Klaus. Humility: Solidarity of the Oppressed. Translated by John Bowden. Philadelphia: Fortress Press 1988.

Westerholm, stephen. Israel's Law and the Church's Faith: Paul and his Recent Interpreters. Grand Rapids : William B. Eerdmans Publishing Co., 1988.

Westerholm, Stephen. "On Fulfilling the Whole Law," SE $\AA$ 51-52 (1986-87) 229-237.

Westerholm, stephen. "Letter and Spirit: The Foundation of Paul ine Ethics," NTS 30 (1984) 229-248.

Willis, Wendell. "An Apostolic Apologia? The Form and Function of 1 Cor 9" JSNT 24 (1985) 33-48.

Windisch, Hans. The Meaning of the Sermon on the Mount. Translated by S. Maclean Gilmour. Philadelphia: Westminster Press, 1951.

Wolff, Christian. "Humility and Self-Denial in Jesus' Life and Message and in the Apostolic Existence of Paul" Paul and Jesus 145-160. Edited by A.J.M. Wedderburn. Sheffield: JSOT, 1989.

Yoder, John Howard. The Politics of Jesus. Grand Rapids: William B. Eerdmans Publishing Co., 1972. 
Ziesler, John. Pauline Christianity. Oxford: Oxford University Press, 1983.

Zimmer 1i, W. "Pais theou" TDNT V, 654-717. 